\author{
UNIVERSIDADE DE SÃO PAULO \\ FACULDADE DE ARQUITETURA E URBANISMO
}

Dulcilei de Souza Cipriano

\title{
A TRANSFERÊNCIA DE POTENCIAL CONSTRUTIVO: \\ INCENTIVO A CONSERVAÇÃO DOS EDIFÍCIOS PROTEGIDOS NA ÁREA CENTRAL DE SÃO PAULO (?)
}

\author{
EXEMPLAR REVISADO E ALTERADO EM RELAÇÃO À VERSÃO ORIGINAL, SOB \\ RESPONSABILIDADE DA AUTORA E DO ORIENTADOR. \\ $A$ versão original, em formato digital, ficará arquivada na Biblioteca da Faculdade. \\ São Paulo, 28 de junho de 2018.
}

Dissertação apresentada à Faculdade de Arquitetura e Urbanismo da Universidade de São Paulo para obtenção de título de Mestre em Arquitetura e Urbanismo

Área de concentração:

Planejamento Urbano e Regional

Orientador:

Prof. Eduardo Alberto Cusce Nobre

São Paulo

2018 
Autorizo a reprodução e divulgação total ou parcial deste trabalho, por qualquer meio convencional ou eletrônico, para fins de estudo e pesquisa, desde que citada a fonte.

Catalogação na Publicação

Serviço Técnico de Biblioteca

Faculdade de Arquitetura e Urbanismo da Universidade de São Paulo

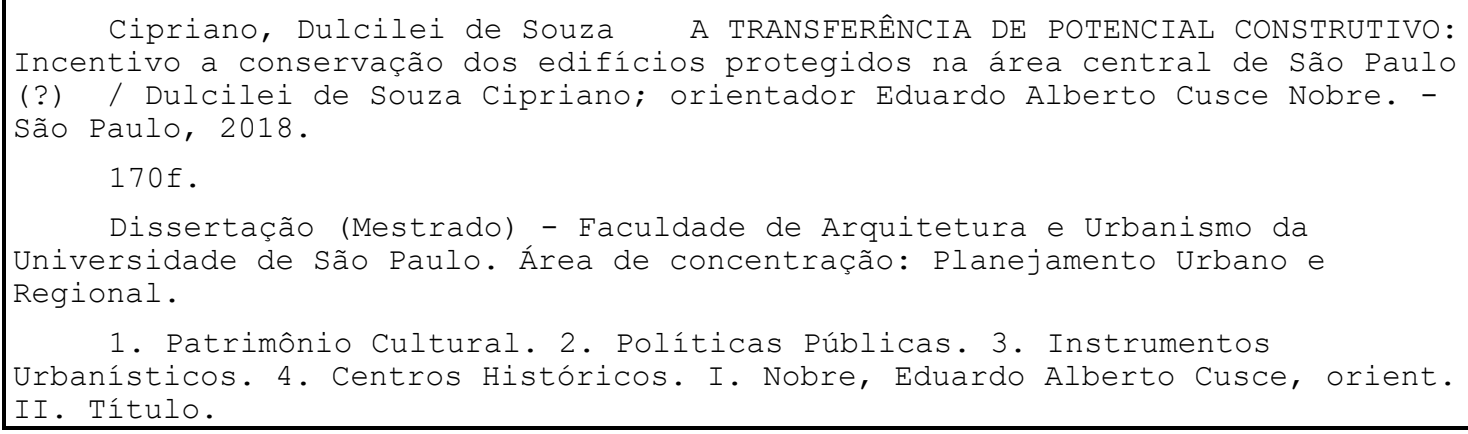

Elaborada eletronicamente através do formulário disponível em: http://www.fau.usp.br/fichacatalografica/ 
Nome: CIPRIANO, Dulcilei de Souza

Título: A Transferência de potencial construtivo: Incentivo a conservação dos edifícios protegidos na área central de São Paulo (?)

Dissertação apresentada à Faculdade de Arquitetura e Urbanismo da Universidade de São Paulo para obtenção de título de Mestre em Arquitetura e Urbanismo

Aprovada em:

Banca Examinadora

Prof. Dr(a)

Instituição

Julgamento

Prof. Dr(a)

Instituição

Julgamento

Prof. Dr(a)

Instituição

Julgamento 
Para minha mãe. 


\section{AGRADECIMENTOS}

ANTONIA DE SOUZA CIPRIANO ALINE ESTEFAM ANA PAULA MOURA PAVAN BEATRIZ KUHL CAMILA MALERONKA CAMILA OLIVEIRA CAROLINA PEDRO SOARES CHRISTIANE RIBEIRO DIMARCH DEBORAH NEVES EDUARDO NOBRE ELIANA BARBOSA ELISABETH WATANABE ENEIDA HECK ERIKA CURTO ERIKA SANTANA EVANIA NAGATOMO GABRIEL ROSTEY GUILHERME PUCCI HE NEM KIM SEO JEROEN STEVENS JOSÉ EDUARDO LEFÈVRE JULIANE ZAITUNE LARISSA NAGASE LIA MAYUMI LUIS GUILHERME RIVERA DE CASTRO LUCAS COELHO LUCIANA COSTA MARCELLA OLIVEIRA MARCO WINTHER MARIA LÚCIA BRESSAN MARIA ESTER DE ARAÚJO LOPES MARINA BRANDÃO MARIANA ROLIM MARIO CIPRIANO MAURO SANCHES NADIA SOMEKH PATRÍCIA SENA PAULA TEDESCO PEDRO SALLES PENHA PACCA ROSANA YAMAGUTI ROSELI DELBOUX SAMIRA BALDIN VALDIR ARRUDA WÁLTER PIRES. MUITO OBRIGADO 


\section{RESUMO}

O presente trabalho busca analisar a aplicação da Transferência de Potencial Construtivo (TPC), no âmbito da Operação Urbana Centro, na área central de São Paulo. Através de uma perspectiva histórica, onde se estuda a formulação da política de preservação brasileira, observando seu caráter distanciado das questões econômicas, de um pensamento prospectivo no que se refere a gestão dos bens protegidos e, ainda, se utilizando da história para embasar a concepção do Solo Criado; procuramos analisar o funcionamento de dois instrumentos internacionais cujos modelos serviram de base para a formatação do nosso objeto de estudo. Em funcionamento há vinte anos, o referido mecanismo é o único instrumento urbanístico que visa promover a conservação do patrimônio cultural edificado por intermédio da concessão de contrapartida financeira, paga pela iniciativa privada, em troca da permissão para exceder o coeficiente de aproveitamento do solo imposto pela legislação de zoneamento. Após a análise dos documentos e dados referentes a operacionalização da TPC iremos verificar a efetividade desta por meio do estudo de dois casos de transferência de potencial, escolhidos num rol de seis processos finalizados durante o período compreendido entre 1997, ano de instituição da Lei №12.349/97 e 2016, quando a Norma Regulamentadora que rege a operacionalização dos trabalhos na Operação Urbana Centro, foi revisada. 


\section{ABSTRACT}

This master thesis aims to investigate the operationalization of the land use regulation tool called Transferência de Potencial Construtivo (TPC), which has been implemented as part of the Operação Urbana Centro in the main area of São Paulo. By studying the formation of Brazil's preservation policy through a historical perspective, observing its character distanced from economic issues; and through a prospective inspection of the management of historic buildings, still using history as the basis of the Solo Criado its conception; we seek to analyse the functioning of two international mechanisms whose models served as the basis for drawing out the instrumental object of our study. In operation since 1997, this mechanism is the only urban instrument that sought to promote the conservation of historic buildings by granting a financial contribution, financed by private initiative, in exchange for the permission to exceed the right to build controlled by zoning. After the analysis of the documents and data pertaining the operation of the TPC we intend to observe the mechanism's effectiveness trough two case studies, selected from a list of six completed processes during the period from 1997, year of establishment of Law No. 12.349/97, and 2016, when the document responsible for the regulation of norms of the Operação Urbana Centro was revised. 


\section{Sumário}

INTRODUÇÃO

Capítulo I - POLÍTICAS DO PATRIMÔNIO CULTURAL E O FINANCIAMENTO DA PRESERVAÇÃO: UM BREVE HISTÓRICO

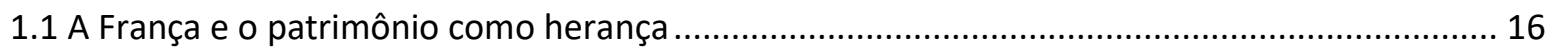

1.2 Preservação do patrimônio nos Estados Unidos da América: entre o público e o privado ........ 22

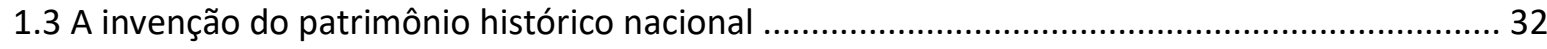

1.40 patrimônio cultural e o desenvolvimento urbano: antecedentes da preservação na Cidade de São Paulo

Capítulo II - FRANÇA E EUA, O MODELO INTERNACIONAL COMO REFERÊNCIA? ...... 46

2.1 França: a preservação de conjuntos e edifícios históricos através de projetos........................... 47

2.2 0 Plafond Légal de Densité e a intervenção do Estado na propriedade ..................................... 67

2.3 Estados Unidos da América, entre planos e projetos ................................................................. 71

2.4 Space Adrift, incentivo para preservação de quarteirões históricos ........................................ 76

Capítulo III - OPERAÇÕES URBANAS E OS BENS PROTEGIDOS NA ÁREA CENTRAL

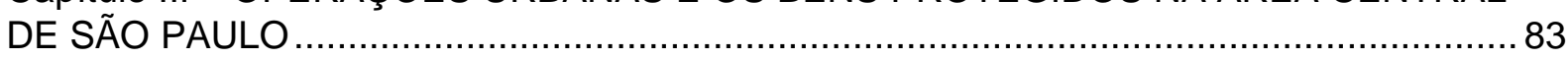

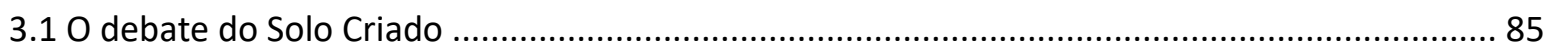

3.2 Antecedentes da Transferência de Potencial Construtivo, a Lei no9.725 e a Operação Urbana

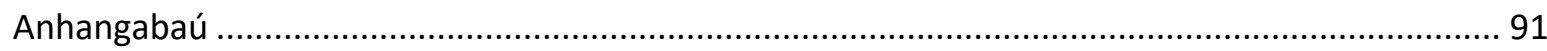

3.3 A Transferência de Potencial Construtivo na Operação Urbana Centro...................................... 98

Capítulo IV - A TRANSFERÊNCIA DE POTENCIAL CONSTRUTIVO COMO INCENTIVO A

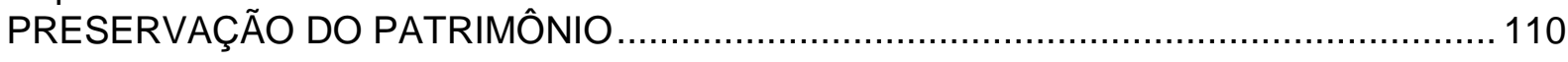

4.1 A transferência de potencial construtivo na área central de São Paulo .................................. 111

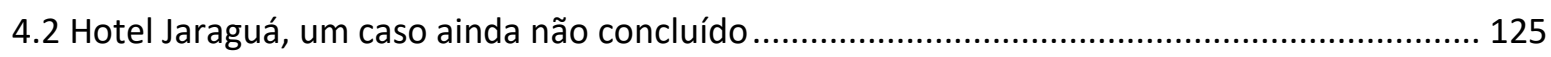

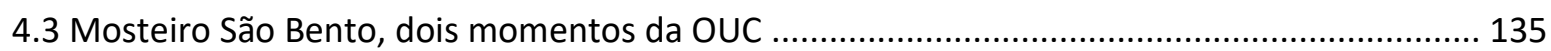

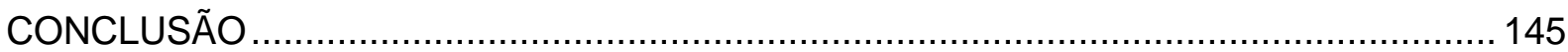

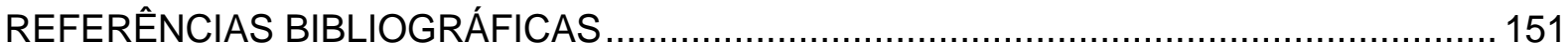




\section{INTRODUÇÃO}

A Transferência de Potencial Construtivo (TPC) se configura como um instrumento urbanístico, previsto no art. 4ํำ da Lei da Operação Urbana Centro (Lei nº 12.349, de 06 de junho de 1997), que tem como finalidade a salvaguarda do patrimônio cultural edificado, mediante o qual o poder público municipal faculta ao proprietário de imóvel tombado na área central de São Paulo, por autorização legal, exercer, ou alienar, o direito de construir legalmente definido e não utilizado em seu lote, total ou parcialmente.

Visando dirimir os conflitos existentes entre os interesses privados da incorporação imobiliária em construir acima do limite instituído pela legislação de zoneamento e, por outro lado, compensar os proprietários de imóveis tombados pela limitação imposta ao seu direito de construir, como também, dos custos advindos com a conservação de um imóvel com valor histórico e cultural; a Prefeitura São Paulo estabeleceu a Transferência de Potencial Construtivo no perímetro da Operação Urbana Centro.

Cabe destacar que, no âmbito federal, a TPC, intitulada TDC - Transferência de Direito de Construir -, é um instrumento da política urbana brasileira previsto no Estatuto da Cidade (Lei Federal no 10.257 , de 10 de julho de 2001), segundo o qual o poder público municipal faculta ao proprietário de imóvel urbano, cujos coeficientes de aproveitamento estabelecidos por lei não podem ser utilizados na área em que se encontram, transferir o potencial construtivo para outros lotes em áreas especificadas.

No caso da referida lei federal a aplicação da TDC pode ser utilizada para fins de implantação de equipamentos urbanos e comunitários, preservação de patrimônio cultural e ambiental, usufruto de programas de regularização fundiária e para fins de urbanização e habitação social. Já no caso municipal aqui estudado, a transferência de potencial construtivo fica exclusivamente condicionada aos imóveis tombados e aos que vierem a ser tombados, conforme art. $7^{\circ}$ da Lei $\mathrm{n}^{\circ}$ 12.349/97.

As primeiras manifestações referentes à Transferência do Direito de Construir surgem na década de 1970, através de um documento elaborado por técnicos da 
Comissão Econômica da Europa da Organização das Nações Unidas, em Roma, em conjunto com especialistas em planejamento urbano, habitação e construção. Neste documento é defendida a separação entre o direito de propriedade e o direito de construção, sendo que o segundo deveria passar a coletividade e ser concedido aos proprietários particulares por concessão ou autorização administrativa.

Pioneiramente, os Estados Unidos, em 1973, estudaram implementar o Space Adrift (traduzido literalmente para espaço flutuante), no Plano para a Cidade de Chicago, prevendo o conceito da transferência do direito de construir. Os terrenos que abrigassem imóveis preservados como patrimônio histórico e cultural, poderiam transferir o seu potencial construtivo para outras zonas da cidade onde a legislação limitava a construção, para isso seria constituído um Banco de Direitos de Construção, cuja administração ficaria a cargo das autoridades públicas, encarregado de gerir os direitos de construção sobre edifícios históricos de propriedade pública e, também, de proprietários privados que fossem doados ao Estado, sendo estes, beneficiados com redução de impostos sobre a renda e a carga tributária. (COSTONIS, 1975)

Na França, em 1975, é formulada uma nova política fundiária e de reforma urbana. Esta visava reduzir as desigualdades sociais decorrentes do zoneamento através de um melhor e maior controle sobre o uso e ocupação do solo, pois constatou-se que o zoneamento vigente contribuía para a desigualdade social corrente. Contava, ainda, em aumentar a participação da coletividade no processo de planejamento, num novo sistema de compartilhamento de responsabilidades entre Estado e Comunas (FURTADO et al. 2011). Neste contexto, o governo francês estabelece uma lei que limita o direito de construção a uma vez a área do terreno, definindo um teto legal de densidade (Plafond Légal de Densité), com exceção de Paris onde o limite ficaria restrito a 1,5. O direito acima deste limite, nos casos em que a legislação permitia, passava à coletividade.

Em São Paulo, a TDC surge através das discussões sobre o Solo Criado, a partir da década de 1970, com alguns pontos em sua formulação coincidindo com os dois exemplos citados anteriormente. Como, por exemplo, a questão da separação entre o direito de construir e o direito de propriedade. A ideia de utilizar este instrumento como forma de controle do solo, começa a ser desenvolvida no Centro de 
Estudos e Pesquisas da Administração Municipal - CEPAM (atual Fundação Prefeito Faria Lima).

A implementação do instrumento tinha como justificativa principal a correção dos problemas de cunho econômico e social causados pela lei de zoneamento, surgindo assim como uma forma de intervenção do Estado sobre a terra. O Solo Criado foi formatado com o objetivo de reequilibrar o atendimento das necessidades da população (CARDOSO; RIBEIRO, 2012). Ainda como justificativa, é colocada a carência de recursos do poder público face ao processo de urbanização. Com isso, o instrumento viria a permitir a repartição entre proprietários de terra, incorporadores e Estado, do ônus criado pela iniciativa privada, e sustentado pelo conjunto da sociedade, na forma de implantação dos equipamentos públicos e da infraestrutura urbana (FURTADO et al., 2011).

No documento elaborado pelo CEPAM, a TDC aparecia como meio de concessão para criação de praças, áreas públicas, preservação do patrimônio histórico e da paisagem das cidades. A vantagem da TDC para o proprietário do imóvel de valor histórico se dava no caso deste imóvel estar situado numa área onde fosse permitida a construção de prédios. Pois, assim, ao invés de permitir a demolição do bem de interesse histórico, o proprietário poderia alienar seu direito de construir a outro proprietário, obtendo com isso as mesmas vantagens que teria com a venda do lote sem necessitar se desfazer do imóvel de valor histórico (CEPAM, 1975).

A aplicação da Transferência de Potencial ${ }^{1}$ Construtivo na cidade de São Paulo remonta aos anos 1980, quando foi estabelecida visando compensar os proprietários de imóveis, na Zona de Uso Especial Z8.200, do ônus representado pela preservação do patrimônio num momento de efervescência construtiva na capital paulista. Podese dizer que, a partir desse momento, a TPC passa a ocupar o status de benefício, único do tipo, concedido a preservação do patrimônio cultural edificado na cidade.

A descaracterização, demolição e subutilização de exemplares de edificações de valor histórico e cultural, localizados, principalmente, na área central de São Paulo, justificaram a preocupação, por parte da municipalidade, em conceber um instrumento normativo que pudesse viabilizar a preservação e conservação do patrimônio cultural

${ }^{1} \mathrm{O}$ instrumento em análise surge com esta denominação, em 1984, na Lei no 9725. (SÃO PAULO, 1984) 
edificado. A demolição em massa de grande número de casarões na Avenida Paulista foi um dos fatores para a proposição do instrumento, que buscava, assim, contribuir com a salvaguarda dos bens históricos e culturais e, ainda, compensar o proprietário do imóvel protegido pela limitação imposta com o tombamento.

Concebido primeiramente como instrumento isolado, a partir dos anos 90 a Transferência de Potencial Construtivo aparece como mecanismo para viabilização das Operações Urbanas, utilizando o mote da preservação do patrimônio construído. A Operação Urbana Anhangabaú fez uso da TPC, ou tentou fazer, como incentivo de atração para investimentos na área central. Mas em seu curto período de vigência não obteve interessados em utilizar a ferramenta. Em 1997, a Operação Urbana Centro (OUC), remodelando algumas diretrizes, oferece novamente a TPC como incentivo a preservação do patrimônio histórico.

A Lei ํํ12.349/97 oferece exceções a legislação vigente na forma de concessões de direitos adicionais de uso, mediante o pagamento de contrapartida financeira à municipalidade, ou seja, a Operação Urbana Centro disponibiliza exceções a legislação vigente mediante pagamento. De um modo geral, os compradores desses "direitos" só podem fazer uso do potencial comprado na área da própria Operação, porém, a regra muda se o interessado demonstrar interesse em investir na restauração de imóveis preservados (JOSÉ, 2009).

Para o comprador interessado em contribuir com a conservação do imóvel tombado, a lei permite a transferência de potencial construtivo para fora da área da OUC, o que para Montandon (2009) resulta em incentivo para a iniciativa privada, ao disponibilizar grande volume de potencial para fora do perímetro da operação. Para José (2009) a OUC se transformou em um polo exportador de coeficiente construtivo para outras zonas da cidade, utilizando a preservação do patrimônio cultural como chamariz.

Em 2017 a OUC completou 20 anos de implantação, desde então, a TPC vem sendo utilizada como instrumento urbanístico destinado a promover a preservação e conservação do patrimônio histórico na área central da cidade. Implementado em três momentos da história da cidade e mantendo sempre o discurso de que este é um mecanismo a favor dos imóveis protegidos, 0 instrumento se encontra em funcionamento há trinta e três anos. Evidencia-se, portanto, o ensejo de uma 
avaliação a respeito de sua trajetória e operacionalização como ferramenta designada a contribuir com a política de preservação do patrimônio histórico.

Diante do exposto o presente trabalho busca analisar o percurso de implementação da transferência de potencial construtivo na área central de São Paulo. Para tanto, a pesquisa se estrutura na análise da implementação da política de preservação em três países, no exame dos antecedentes nacionais e internacionais para a formulação do conceito de Solo Criado e na descrição da experiência da TPC na área central de São Paulo, procurando assim avaliar o período de funcionamento do instrumento e sua contribuição ao patrimônio cultural edificado no perímetro da Operação Urbana Centro.

A dissertação está organizada em quatro capítulos. No Capítulo I será analisada a formulação da política de preservação no Brasil, na França e nos Estados Unidos da América, observando a abordagem adotada para a proteção de bens imóveis através da destinação de recursos para a preservação destes e, buscando compreender como isto contribuiu para a gestão futura do patrimônio, do ponto de vista econômico.

No Capítulo II, estudaremos planos e projetos urbanos formulados com vistas a contribuir para a preservação do patrimônio na França e nos Estados Unidos, averiguando como estes modelos internacionais lidam com a questão do patrimônio histórico urbano, principalmente, aquele localizado nas áreas centrais. E, examinando como estes dois países, cujos instrumentos urbanísticos serviram de base para a Transferência de Potencial Construtivo, formularam mecanismos que procuram contribuir com a preservação dos bens históricos averiguando a operacionalização destes.

Já ao Capítulo III destinamos a análise dos primórdios da Transferência de Potencial Construtivo em São Paulo, através de um percurso histórico que se inicia com os debates acerca do Solo Criado, passando pela implantação da Operação Urbana Anhangabaú e Centro, verificando a influência dos modelos internacionais em sua concepção e, buscando analisar como se deu a formulação do instrumento que é o nosso objeto de estudo. 
E, por fim, no Capítulo IV estudaremos a Transferência de Potencial Construtivo no contexto da Operação Urbana Centro, observando sua funcionalização e implementação através do estudo de dois casos emblemáticos sobre o tema: o Hotel Jaraguá e o Mosteiro São Bento, buscando identificar sua contribuição na preservação e conservação dos imóveis tombados.

Ainda com vistas a atender o assunto aqui proposto, o estudo em questão foi embasado através do exame da literatura existente que trata do tema, pesquisa e análise de dados primários, entrevistas com agentes públicos e privados que fizeram parte dos processos aqui apreendidos, investigação da legislação concernente ao tema estudado, averiguação do método de cálculo utilizado para implantar o instrumento urbanístico e visitas a campo para apreensão e verificação do estado atual dos objetos de estudo de caso, em análise nesta dissertação. 
Capítulo I - POLÍTICAS DO PATRIMÔNIO CULTURAL E O FINANCIAMENTO DA PRESERVAÇÃO: UM BREVE HISTÓRICO 


\subsection{A França e o patrimônio como herança}

Embora pareça exaustivo iniciarmos o capítulo apontando os percalços e sucessos da política de preservação francesa, pensamos ser importante este retorno ao passado, que não é o brasileiro, mas que, contudo, contribuiu sobremaneira para a criação da nossa política de preservação. Baseando-se no fato daquela, a política de preservação na França, ter sido durante um longo período, modelo tanto para a Europa quanto para diversos países emergentes, neste caso, o Brasil, devido sua clareza e racionalidade de procedimentos (CHOAY, 2006).

Justifica-se, ainda, o intuito de iniciar o capítulo com tal tema tendo em vista a necessidade de embasar e abrir caminho para um assunto que mais tarde será discutido nesta dissertação: o caso de um instrumento urbanístico criado na França, o Plafond Légal de Densité, para contribuir com a preservação do patrimônio e que teve reverberação aqui no Brasil nos anos 70. Assim sendo, entendemos ser importante este breve panorama da institucionalização da política de preservação cultural na França já que a criação de tal instrumento visava atender uma demanda, tanto aqui quanto lá, e sendo assim, estava atrelado ao modo como se fazia a política de preservação.

Resumindo, pois, visto que o assunto ainda será abordado pormenorizadamente, se o instrumento urbanístico francês criado para contribuir com a preservação do patrimônio cultural naquele país serviu como base para o instrumento urbanístico brasileiro, nada mais perspicaz que, primeiramente, entendamos como se deu a intervenção do Estado na preservação do patrimônio cultural na França. Deste modo podemos enredar nas tentativas brasileiras de criar um instrumento cuja atribuição seria de contribuir para a preservação de um patrimônio, que tem em sua política pública um preâmbulo muito distinto da francesa.

A intervenção do Estado francês na regulamentação da preservação do patrimônio cultural remonta ao século XIX, quando é criado o cargo de Inspetor Geral dos Monumentos. Reconhecemos o fato da Revolução Francesa ter contribuído para a estruturação política, ideológica e cultural do mundo contemporâneo, contudo, o 
modelo de jurisdição sobre o patrimônio, na forma como hoje utilizamos, tem seu início com a criação do cargo de Inspetor Geral, em 1830 (CHOAY, 2011).

O controle do Estado francês nas questões de preservação teve como premissa a necessidade de criação de uma unidade nacional. Já existia, em nível local, uma legislação de preservação era essencial promover um consenso em torno da memória coletiva, compartilhada por todas as tendências políticas existentes naquela época. Assim, em 1830, François Guizot (1787-1874), ministro do Interior, se utilizando da necessidade em propor às Câmaras do Reino a alocação de fundos para a conservação dos monumentos, redige uma carta ao rei sugerindo a criação de um cargo de Inspetor Geral dos monumentos históricos, defendendo que esse seria o responsável por centralizar e direcionar claramente a zeladoria dos monumentos perante às autoridades locais (GREFFE, 2014).

A criação do cargo de inspetor geral dos monumentos históricos da França parece-me responder a essa necessidade. A pessoa a quem se confiar essa função deverá antes de mais nada procurar meios de dar às intenções do governo um caráter de conjunto e de regularidade. Para isso, ela deverá percorrer, um após outro, todos os departamentos da França, certificar-se in loco da importância histórica ou do valor artístico dos monumentos, colher todas as informações referentes à distribuição dos documentos ou objetos acessórios que podem esclarecer sobre a origem, os progressos ou a destruição de cada edifício, [...] Deverá informar aos proprietários sobre a importância dos edifícios cuja conservação depende de seus cuidados e estimular, enfim, orientando-o, o zelo de todos os conselhos de departamento e das municipalidades, de forma que nenhum monumento de valor incontestável pereça em razão da ignorância ou da precipitação [...], e de modo também que a boa vontade das autoridades ou dos particulares não se esgote em objetos indignos de seus cuidados (CHOAY, 2009, p.259-262).

A criação da Comissão de Monumentos Históricos, em 10 de agosto de 1837, permitiu à Administração Central agilizar o processo de listagem ${ }^{2}$ proposto por Prosper Merimée (1803-1870), inspetor geral de 1834 a 1860, e a impor seu poder sobre a

\footnotetext{
${ }^{2}$ A fim de contribuir com a Comissão no objetivo de escolher os imóveis a serem restaurados, através da circular de 10 de agosto de 1837, o ministro do Interior solicita aos prefeitos a elaboração de uma lista dos monumentos, pertencentes aos seus respectivos departamentos, que necessitam de assistência monetária para sua conservação, e de classificá-los por ordem de importância. Esta é a primeira listagem dos edifícios classificados como monumentos históricos, intitulada "Lista de 1840". (BORDAS et al., 2005, p. 149).
} 
preservação de monumentos nas Municipalidades e Departamentos, sendo que este recaia principalmente sobre os bens públicos e de propriedade do clero. Considerando que o tombamento ${ }^{3}$ de imóveis particulares ficava sujeito à anulação caso o proprietário não estivesse de acordo (BORDAS et al., 2005).

A vantagem em se criar uma Comissão, e com ela um sistema, era fundamentada na investidura do Estado na propriedade através de um instrumento: o tombamento. Cita-se que entre 1840 e 1849, na França, o número de imóveis tombados passou de 934 a 3000 cujas regras de seleção eram ditadas por questões pragmáticas e econômicas de uma política de conservação e proteção. (CHOAY, 2009).

Outra questão importante a ressaltar acerca da criação da Comissão, se insere no que diz respeito aos aportes financeiros para a conservação dos monumentos históricos, posto que estes aumentaram com a promulgação da mesma. O aumento foi considerado tomando como base a quantia que anteriormente as Municipalidades e os Departamentos já disponibilizavam em seus orçamentos para este tipo de obra, e, com a centralização das questões de preservação pelo Estado, o aporte passou a ser maior, contudo, nunca suficiente para suprir a demanda (RUCKER apud CHOAY, 2009).

É importante lembrar que, neste momento, a soma de imóveis tombados abarcava, em sua grande maioria, imóveis públicos, os quais absorviam toda a verba que a Administração Central destinava para conservação dos monumentos. Porém em $1913^{4}$, foi aprovada uma nova lei que estabeleceu a servidão administrativa sobre os monumentos de propriedade privada, significando, assim, que deste ponto em diante o proprietário privado enfrentaria maiores dificuldades e dificilmente conseguiria anular o tombamento de seu imóvel, algo passível de ser realizado anteriormente à aprovação da citada lei (AUDUC, 2008).

\footnotetext{
${ }^{3} \mathrm{Na}$ França o termo classement (classificação. Tradução da autora) é o correspondente ao nosso, em linhas gerais, tombamento. Tal termo foi utilizado pela primeira em uma circular enviada por Prosper Merimée aos prefeitos franceses em 1837 e em 1913 pela lei de monumentos históricos o termo foi legalmente reconhecid (GOUVEIA; MICELI, 1985). A classificação significa proteção total do bem, que corresponde ao desejo de manter permanente a situação de um local assim como este estava quando foi designado, o que não exclui gerenciamento ou avaliação (FRANÇA, 2017).

${ }^{4}$ Loi complétant la loi du 31 décembre de 1913 sur les monuments historiques. (FRANÇA, 1913).
} 
Com a aprovação da lei de 1913, o número de imóveis tombados aumentou e então, em 1914, numa tentativa de suprir a demanda por conservação ampliada por este novo conjunto de monumentos, conforme previsto na mencionada lei, foi criada a Caixa Nacional de Monumentos Históricos e Pré-Históricos, responsável por gerir os recursos para a proteção fazendo com que estes aumentassem. Porém, ainda existiam muitos entraves burocráticos para que um proprietário de imóvel privado conseguisse aporte financeiro para conservação de seu bem (CHAVES et al., 2015).

Após o início da Primeira Guerra Mundial, o debate acerca da preservação de monumentos se fortaleceu, tanto no que se aludia à sua conservação, quanto no que dizia respeito a este como anteparo aos ideais nacionalistas. O período do entre guerras foi de grande restauração e reconstrução de monumentos, porém foi, também, um período abalado por momentos de crise econômico-financeira (anos 1920 e 1930) que influenciaram os financiamentos das ações de conservação do patrimônio na França.

Em 1927, foi aprovada a Lei do Inventário Suplementar ${ }^{5}$, responsável por proteger uma quantidade maior de monumentos sem, contudo, tombá-los. Esta lei surgiu devido à rigidez do instrumento do tombamento e das exigências à conservação dos imóveis tombados e seus correspondentes custos. Foi responsável ainda por centralizar as ações de restauração e estudo das formas de proteção nas mãos do poder central, enquanto a conservação e inventário ficariam sob responsabilidade de profissionais locais e das universidades. Contudo, os arquitetos do governo central continuaram tendo a última palavra mesmo nos trabalhos que já não Ihes cabiam, pois estes encarnavam o Estado francês, que, por sua vez, era responsável pelo maior montante de orçamento destinado à preservação (LAURENT, 2003).

Apesar dos avanços realizados durante este período, na implementação de uma política de preservação para os imóveis tombados na França, havia ainda um longo caminho a trilhar. Entre os anos 1920 e 1960, algumas leis foram aprovadas trazendo melhorias e demonstrando um maior conhecimento acerca da matéria. Porém, todas esbarravam na questão mais premente à época, que era a necessidade de se inventariar todos os bens da França para assim se ter um panorama geral do

\footnotetext{
${ }^{5}$ Loi complétant la loi du 31 décembre de 1913 sur les monuments historiques. (FRANÇA, 1913).
} 
patrimônio francês e com isso verificar e elucidar questões urgentes, como por exemplo, a destinação de verba para conservação dos imóveis. O conhecimento do rol de bens que compunham o patrimônio francês traria, também, a eleição de quais deveriam estar no topo da lista para receber maiores cuidados, assim como, os quais efetivamente representavam a nação francesa.

Em 1962, foi aprovada uma lei ${ }^{6}$ que complementava as leis anteriores, visando a proteção do patrimônio e destinada a facilitar a restauração e conservação dos imóveis. A Lei Malraux ${ }^{7}$, como ficou conhecida posteriormente, instituía em seu artigo $1^{\circ}$ a criação de setores salvaguardados, perímetros que receberiam incentivos do governo para manter as características históricas, estéticas e arquitetônicas dos imóveis. Mas para isso, um setor salvaguardado deveria ser composto por um grupo de imóveis, ou de parte destes que se complementassem em sua significância cultural (fosse ela estética, histórica e/ou paisagística), e neste momento da história francesa ainda existiam critérios rígidos para eleição da arquitetura menor ${ }^{8}$, que somavam maioria dentro de um perímetro a ser salvaguardado como patrimônio cultural.

Era necessário reconhecer toda manifestação artística da França para assim se ter um espectro dos bens a serem preservados, fossem eles móveis ou imóveis e, por conseguinte receberem incentivos do governo para sua conservação. Tal projeto foi esboçado antes mesmo da aprovação da Lei Malraux, em 1961, porém, somente com a institucionalização desta lei e sua regulamentação através de decreto, em 4 de março de 1964, o Inventário adquiriu um caráter legal. Duas questões essenciais foram abordadas: primeiro, a aprovação, neste mesmo Decreto, do trabalho compartilhado sobre o patrimônio cultural, legalizando assim a figura do voluntário. Deste modo podemos vislumbrar o montante de bens a serem inventariados e que este trabalho não conseguiria sua plenitude com o corpo técnico de preservação existente a época. A segunda questão foi de encontro à necessidade de ancorar os trabalhos de inventário nos esquemas de planificação pois o jovem Departamento dos

\footnotetext{
${ }^{6}$ Loi $n^{\circ}$ 62-903 du 4 août 1962 complétant la législation sur la protection du patrimoine historique et esthétique de la France et tendant à faciliter la restauration immobilière. (FRANÇA, 1962).

7 A lei ficou conhecida pelo nome de seu criador André Malraux (1901 - 1976) que foi ministro da cultura, no período de 1959 a 1969, durante a 5 República sob o governo de Charles de Gaulle.

8 Chamamos aqui de arquitetura menor as construções que não tinham os valores conhecidos: estéticos, artísticos e históricos, mas sim um valor do de arte a ser ainda descoberto, como enfatiza Malraux no prefácio da publicação L'inventaire general des monuments et des richesses artistiques de la France (FRANÇA, 2009).
} 
Assuntos Culturais - Ministério da Cultura, necessitava da expertise tecnocrática como uma garantia de seriedade e perenidade (LAURENT, 2016).

O Inventário Geral foi responsável pelo reconhecimento de bens menores, aqueles que não faziam parte da Idade Média ou do estilo gótico, como patrimônio. Pois, segundo Malraux, as obras menores exprimiam toda a riqueza da França. $E$ isto foi possível graças a consideração de um outro tipo de valor, diferente dos valores históricos e estéticos, que eram comumente utilizados, mas acreditando no valor do objeto quando considerado num contexto mais amplo, uma peça para a engrenagem da arte (FRANÇA, 2009).

A Lei Malraux se apresentou para os setores salvaguardados como uma continuação lógica de meio século de legislação de preservação. Ela foi uma resposta à reflexão, iniciada em 1930, com a lei sobre sítios históricos. A imposição de servidão administrativa ${ }^{9}$ aos proprietários de terras permitiu proteger as paisagens urbanas $\mathrm{e}$ combater o desenvolvimento desenfreado das cidades. A Lei $\mathrm{n}^{0}$ 62-903 foi ainda responsável por implementar a concessão de incentivos para a preservação e valorização do patrimônio cultural. Esses incentivos, mesmo concedidos de forma modesta, criaram uma flexibilidade jamais concebida em matéria de trabalhos com edifícios protegidos (LAURENT, 2003).

Neste texto examinamos a concepção da política de preservação francesa até os anos 1960, quando foi instituída a Lei Malraux que trata, entre outros, da instituição de incentivos aos proprietários de imóveis objeto de preservação. Buscamos com isso demonstrar como este país sempre considerou as questões econômicas atreladas à conservação do patrimônio cultural edificado. Entendemos que tal direcionamento contribuiu sobremaneira na formulação de incentivos que auxiliam, ainda hoje, na conservação dos bens protegidos. Como exemplo, temos o instrumento Plafond Légal de Densité, cuja base serviu de modelo para elaboração da Transferência de Potencial Construtivo, instituído para controlar a densidade e dirimir a pressão do mercado imobiliário frente aos bens de interesse históricos e cujo funcionamento iremos abordar no segundo capítulo deste trabalho.

\footnotetext{
9 Servidão administrativa: imposição da Administração Pública à propriedade particular, a fim de permitir a efetivação do interesse público, seja com a realização de obras ou outros serviços de utilidade pública. (DI PIETRO, 2016)
} 


\subsection{Preservação do patrimônio nos Estados Unidos da América: entre o público e o privado}

Ainda com propósito de fundamentar o nosso objeto de estudo, iremos abordar neste texto a análise da política de preservação do patrimônio nos Estados Unidos da América (EUA). Tal enfoque se faz necessário considerando que neste país foi formulado um instrumento de incentivo à preservação do patrimônio cujo modelo serviu de referência para a criação do instrumento brasileiro o qual estaremos analisando. De antemão declaramos que estamos cientes das particularidades em relação à questão da preservação em países anglófonos, assim como da diferença na estrutura administrativa e legislativa, e, também neste sentido, é que se faz necessária a pesquisa abaixo.

O início da preservação de monumentos nos Estados Unidos se deu através da iniciativa privada e, ocasionalmente, por governos estaduais e locais. Contudo, a primeira legislação de preservação foi aprovada somente em 1906, através do Antiquities $A c t^{10}$, responsável por proibir a escavação não licenciada em sítios arqueológicos localizados em terras federais, assim como a escavação em ruínas indígenas. Esta lei também foi responsável por autorizar o National Park Service (NPS) ${ }^{11}$, a identificar, estudar, adquirir e proteger imóveis cuja significância recaia em sua importância frente a história e eventos comemorativos para a nação americana (THE COUNCIL, 1986).

Com a promulgação do Antiquities Act podemos destacar dois pontos fundamentais: a questão das terras privadas, visto que a lei só tinha jurisdição sobre terras públicas, pois o texto não especificava a obrigatoriedade do governo em prever dotação orçamentária para a compra de propriedades, assim como a indicação de qualquer local privado já era ato negado simplesmente por sua condição frente à

\footnotetext{
${ }^{10} \mathrm{Em}$ tradução livre - Lei das Antiguidades. (E.U.A. 1906)

11 "O Serviço de Parques Nacionais (Tradução da autora) foi estabelecido em 1916, dez anos após a instituição do Antiques Act, pelo Departamento do Interior dos EUA como a agência administrativa responsável pelos parques nacionais. O objetivo era estabelecer um aparelho para lidar com sítios muito grandes para proteção ou preservação privada, como Jamestown e Yorktown na Virgínia, que foram combinados para formar o Parque Histórico Regional Nacional (Colonial National Historical Park). Como o seu envolvimento inicial com a proteção de sítios naturais, o Serviço de Parques Nacionais sempre desempenhou um papel fundamental na preservação no nível federal." (LIGIBEL et al., 2000. p. 34)
} 
sociedade. O segundo entrave não solucionado por esta lei dizia respeito ao controle de obras federais em parques nacionais. O Antiquities Act regulava somente a preservação de remanescentes arqueológicos e indígenas, desde que estes não ocorressem em áreas de obras do governo, ou seja, as obras públicas poderiam agir livremente destruindo o patrimônio pré-histórico do país (E.U.A., 1906).

Com a aprovação da lei, as indicações de locais a Parques Nacionais aumentaram consideravelmente, contudo, em sua grande maioria, as áreas indicadas não preenchiam os requisitos necessários para se enquadrar nesta categoria, se levarmos em consideração os dois primeiros parques aprovados, Yellowstone ${ }^{12}$ e Yosemite $^{13}$. Sendo assim, tanto pelo não enquadramento quanto para restringir as indicações a parques nacionais, o Departamento do Interior criou uma categoria adicional de locais de interesse. Se um local fosse indicado a Parque Nacional e o governo federal não concordasse com a indicação por esta não preencher os requisitos necessários a compor o grupo dos parques, como dimensão, significância frente à pré-história ou história americana e à natureza, a área era inscrita como monumento nacional ${ }^{14}$ (ROTHMAN, 1989).

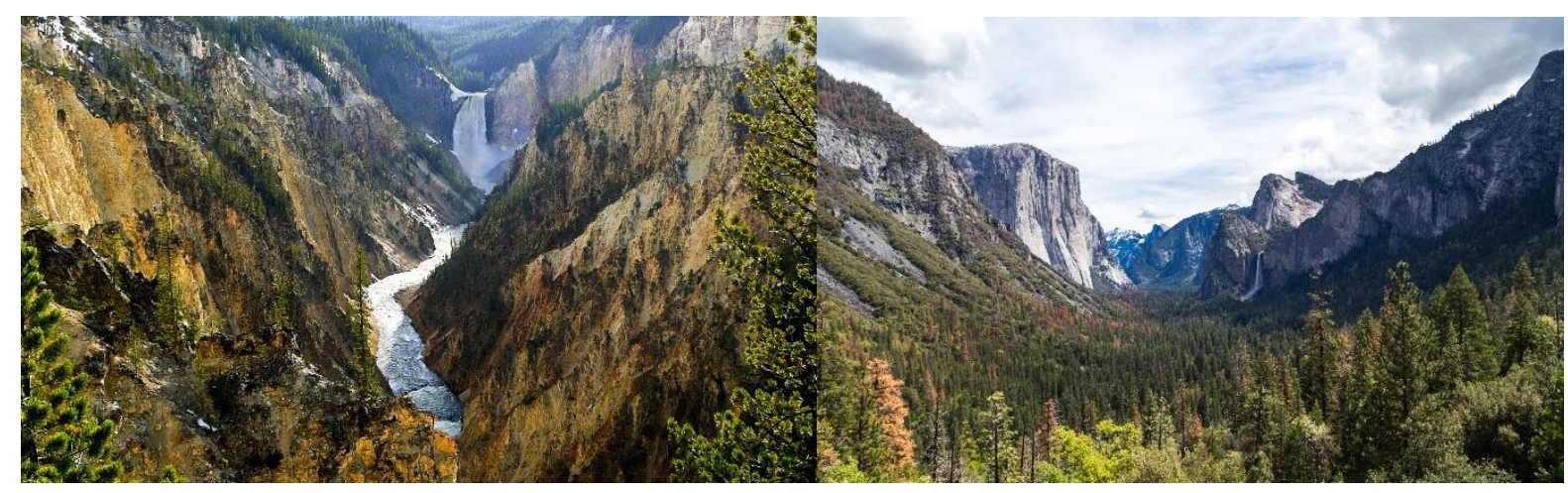

Figura 1.1 - Parque Nacional Yellowstone (imagem à esquerda) e Parque Nacional Yosemite (imagem à direita). Disponível em: https://www.goodfreephotos.com. Acesso em ago. 2017

Os monumentos nacionais, em sua maioria, eram inscritos como de interesse científico, pois esta era a brecha que a legislação dispunha quando da proclamação

\footnotetext{
12 Yellowstone foi criado 1872 e serviu de modelo para o estabelecimento dos demais parques nacionais. Disponível em www.nps.gov .Acesso em 04 jul. 2017.

13 Yosemite foi criado 1864. Disponível em www.nps.gov. Acesso em 04 jul. 2017.

14 Posteriormente, em 1966, passaram a se chamar National Historic Landmarks.
} 
de uma área que não se enquadrasse nos parâmetros de valor pré-estabelecidos pela lei.

Sec. 2. That the President of the United States is hereby authorized, in his discretion, to declare by public proclamation historic landmarks, historic and prehistoric structures, and other objects of historic or scientific interest that are situated upon the lands owned or controlled by the Government of the United States to be national monuments, and may reserve as a part thereof parcels of land, the limits of which in all cases shall be confined to the smallest area compatible with proper care and management of the objects to be protected: Provided, That when such objects are situated upon a tract covered by a bona field unperfected claim or held in private ownership, the tract, or so much thereof as may be necessary for the proper care and management of the object, may be relinquished to the Government, and the Secretary of the Interior is hereby authorized to accept the relinquishment of such tracts in behalf of the Government of the United States ${ }^{15}$ (E.U.A., 1906,online).

E, como resultado da facilidade com que um monumento nacional era reconhecido, essa categoria se tornou um depósito de bens cujos propósitos para preservação eram distintos e, na maioria dos casos, injustificados visto que as indicações de muitas áreas, imóveis e elementos a parques nacionais derivavam de interesses pessoais e, também, não necessitavam do aval do Congresso, requerendo somente uma assinatura do presidente ${ }^{16}$ (ROTHMAN, 1989).

A promulgação do Antiquities Act foi uma resposta às demandas de vários grupos defensores da preservação dos monumentos e de algumas agências governamentais. A lei apresentou questões administrativas e de jurisdição que facilitaram a proclamação de sítios históricos como monumentos nacionais. Contudo, deixou muitos pontos em aberto, como, por exemplo, o não ordenamento do

15 Seção 2 - Que o Presidente dos Estados Unidos é autorizado, a seu critério, a declarar por proclamação pública marcos históricos, estruturas históricas e pré-históricas e outros objetos de interesse histórico ou científico que se situam nas terras de propriedade ou controladas pelo Governo dos Estados Unidos para serem monumentos nacionais, e podem reservar-se parte de parcelas de terra, cujos limites devem, em todos os casos, limitar-se à área mais pequena, compatível com cuidados adequados e gestão dos objetos a serem protegidos: desde que, quando tais objetos estiverem situados em um trato coberto por uma reivindicação falsa e não protegida ou mantida em propriedade privada, o trato, ou o mesmo que for necessário para o cuidado e gerenciamento adequados do objeto, pode ser renunciado ao Governo e o Secretário do Interior fica autorizado a aceitar a renúncia a tais partes em nome do Governo dos Estados Unidos. Tradução da autora.

16 A diferença entre parques nacionais e monumentos nacionais se dava no modo de seu estabelecimento, pois o primeiro necessitava de aprovação pelo congresso norte americano já o segundo era proclamado pela assinatura do presidente (ROTHMAN, 1989). 
financiamento como forma de contribuição ao estabelecimento de um sistema de cuidados para os monumentos (E.U.A., 1906).

Nos anos que se sucederam ao Antiquities Act, o avanço em matéria de proteção aos monumentos ainda era ínfimo. Os três departamentos ${ }^{17}$ responsáveis pela salvaguarda dos bens não foram capazes de formalizar um processo administrativo que norteasse o trabalho de salvaguarda, e estavam cientes que somente a eleição de uma área a Parque Nacional ou a monumento nacional já não era suficiente para garantir sua proteção frente a degradação. Se fazia urgente a criação de um órgão específico para tratar do tema do ponto de vista que sua amplitude exigia (LIGIBEL et al., 2000).

Cumpre ainda salientar que a lei de 1906 foi estabelecida para proteger um tipo específico de monumento - sítios pré-históricos e históricos -, no oeste do país. Enquanto isso, no leste dos EUA, grupos privados se mobilizavam, através da construção de sociedades preservacionistas, para salvaguardar edifícios de interesse histórico e estético. Estes grupos compravam os imóveis de interesse histórico, restauravam ou financiavam o restauro, e, posteriormente, formulavam regras para ocupação dos edifícios (ROTHMAN, 1989).

Não obstante os esforços dessas instituições e associações privadas, em preservar os monumentos e tentar difundir o gosto pelo passado histórico das construções, o resultado ainda era incipiente. Esta preocupação vinha desde 1893, quando uma feira na cidade de Chicago buscou colocar em evidência o movimento preservacionista através da preservação do patrimônio associada a esforços de melhorias cívicas, que se configuravam em belos edifícios públicos centralmente locados e planos urbanos como antídotos ao crescimento desordenado das cidades do século XIX (STIPE, 2003).

The Columbian Exposition, with its classically derived, magnificent buildings contained within a site designed by Olmsted and his colleague, Chicago architect Daniel H. Burnam, gave rise to a new vision of urban America that came to be known as the "City Beautiful". (STIPE, 2003, p. 4)

O Movimento City Beautiful levou à criação de numerosas sociedades artísticas que procuraram obter meios legislativos para a implantação de regulamentação

17 O Serviço Florestal, O Departamento de Interior e o Departamento de Guerra (ROTHMAN, 1989). 
estética nas cidades. Essa ideia acabou levando à preservação de estruturas históricas para o bem público, com a aprovação de algumas leis em diferentes Estados norte-americanos. O movimento também contribuiu para a construção de estradas ajardinadas $^{18}$, ligando monumentos públicos, edifícios e parques.

Em 1916, enquanto os preceitos do City Beautiful permaneciam contribuindo na redefinição das cidades, a partir da preservação de seus edifícios e monumentos, foi aprovada no Congresso a criação de uma agência responsável por administrar e proteger a crescente lista de parques nacionais, focando principalmente nos grandes sítios históricos, cuja jurisdição cabia a mais de dois estados. O National Park Service foi instituído com um orçamento inicial de $\$ 19.500$ (dezenove mil e quinhentos dólares) e um corpo técnico composto por um diretor, um assistente e um escriturário que realizavam trabalho voluntário, sob responsabilidade do Departamento do Interior e sendo o único responsável, daquele momento em diante, a lidar com as questões relativas aos parques nacionais (STIPE, 2003).

Agora a preservação de parques tinha uma agência para regular os trabalhos, contudo todas as áreas estavam estritamente locadas no oeste americano e, considerando que o NPS foi instituído para ser um sistema de preservação nacional, era necessário expandir seus domínios para o leste. Mas, as terras do Leste, em sua maioria, eram de domínio privado, e as públicas que restavam em nada se comparavam em beleza e dimensão às terras do Oeste que justificassem sua eleição como Parque Nacional. Ainda, agregando a tudo isso, havia a questão orçamentária, pois, o NPS não dispunha de fundos para a compra de terras privadas.

O problema da expansão dos parques nacionais para o Leste foi resolvido com a doação de uma área de cinco mil acres no estado do Maine, o Sieur de Monts Spring National Monument, caracterizada por um trecho de penhascos acidentados, a beiramar, próximos a um local de férias para as elites norte-americanas. O Parque surgiu como solução tanto para o NPS, que necessitava expandir seus domínios, quanto para a elite local, ansiosa por barrar a expansão urbana naquele trecho do estado (ROTHMAN, 1989).

18 No original: landscaped roadways. 
Apesar do NPS estar interessado em expandir geograficamente seus domínios, o mesmo não fazia esforços para cuidar de áreas já obtidas, como era o caso dos monumentos nacionais, que continuaram sendo ignorados pelo sistema, enquanto os parques nacionais tinham um orçamento fixo para manutenção, contavam com voluntários treinados para receber os visitantes e propagar educação ambiental e dispunham também de uma rede de estradas construídas com objetivo de levar visitantes até aqueles locais.

Em meados de 1930, os parques e monumentos nacionais que estavam sob jurisdição do Departamento de Guerra passaram a pertencer ao NPS. Com isso, o número de áreas administradas pela agência mais que duplicou. Contudo, estes eram os anos subsequentes a Grande Depressão ${ }^{19}$ e a administração Roosevelt providenciou um programa back-to-work ${ }^{20}$, para os milhares de norte-americanos desempregados, utilizando a preservação histórica, e o NPS, como base. Este foi o momento de virada na história do National Park Service, quando a agência recebeu fundos para empregar uma grande quantidade e variedade de funcionários, entre estes muitos arquitetos e fotógrafos que foram destacados para preparar um levantamento completo dos principais edifícios históricos do país ${ }^{21}$ e realizar obras de melhorias nos parques nacionais (GRAY, 1971).

No ano de 1935 foi promulgada pelo Congresso o Historic Sites, Buildings, and Antiquities Act., uma lei nacional que visava a preservação de sítios históricos, edifícios e objetos significativos para a nação. Esta lei foi importante pois autorizou o secretário do Departamento do Interior a conduzir um número relevante de ações para proteção destes locais, liberando o departamento para realizar compras, restauros, manutenção e administração dos bens, assim como guiar pesquisas visando identificar propriedades, privadas principalmente, com potencial de inclusão no cadastro do National Park System. Contudo, as propriedades privadas, significativas a nível nacional, que não se enquadravam nos parâmetros de parques eram

\footnotetext{
${ }^{19}$ A queda no mercado de ações sinalizou o início da Grande Depressão, mas foi apenas um fator entre muitas causas profundas da Depressão. Um sistema bancário fraco, um colapso adicional em preços agrícolas já baixos e a superprodução industrial contribuíram para a recessão econômica. A crise foi a pior desaceleração econômica da história dos Estados Unidos da América (McELVAINE, 1993).

${ }^{20}$ Volta ao trabalho. Tradução da autora.

21 The Historic American Building Survey (HABS),tornou-se o primeiro inventário nacional sobre edifícios históricos (STIPE, 2003).
} 
nomeadas como National Historic Landmarks $(\mathrm{NHLs})^{22}$. As listas derivadas destas pesquisas foram a base para a criação do National Register of Historic Places ${ }^{23}$ (NRHP) (E.U.A., 1935).

O Historic Sites, Buildings, and Antiquities Act. também instituiu a criação de um Conselho Consultivo que tem, até hoje, a função de aconselhar o diretor do NPS assim como o secretário do Departamento do Interior sobre assuntos referentes ao sistema de Parques Nacionais e aos programas administrados pelo National Park Service. Tem também como função designar os National Historic Landmarks, e para isso, é altamente recomendado que realize consulta com membros da academia e de organizações profissionais buscando com isso ampla, e especializada, legitimação do objeto proposto (E.U.A., 1935).

Aqui, podemos vislumbrar alguns avanços em relação ao Antiquities Act, visto que a Lei de 1935 previa, além do conselho consultivo que tem, até os dias atuais, como objetivo tornar democrática a nomeação dos monumentos; programas a serem administrados pelo NPS, demonstrando assim uma vontade em pensar os monumentos para além do ato de inscrição. Outra questão importante diz respeito a menção da, como o próprio nome da Lei estabelece, preservação de edifícios e objetos de significância nacional.

Mas, apesar da inclusão de edifícios na lei aprovada em 1935, este era um assunto que necessitava maior delineamento por parte da legislação. Pois o edifício só viria a ser nomeado como monumento caso o Departamento do Interior o comprasse ou recebesse este como doação. Os proprietários de imóveis com interesse histórico mantinham o direito total sobre sua propriedade, sendo assim o Estado não podia intervir nomeando-a como monumento. Como consequência muitos imóveis eram modificados e até mesmo demolidos, sem que o National Park Service pudesse interferir (GRAY, 1971).

A lei de 1935 incluiu os edifícios no sistema de preservação do National Park Service contudo, a legislação norte-americana prevê um governo federal derivativo

\footnotetext{
22 Locais históricos significativos, edifícios, estruturas ou objetos, nacionalmente porque possuem valor ou qualidade excepcional na ilustração ou interpretação da herança dos Estados Unidos. Disponível em: https://www.nps.gov/nhl/ Acessado em: 24.08.2017

23 O National Register of Historic Places foi instituído em 1996 através do National Historic Preservation Act e se constitui como a lista oficial dos lugares históricos significativos à nação norte-americana. Disponível em www.nps.com. Aceso em 14 jan.2017
} 
significando com isso que os estados detém maior poder. Logo, a preservação dos edifícios, após a promulgação da lei, continuou a ser realizada pelas organizações privadas locais. E, como descrito a princípio, historicamente a preservação nos EUA era realizada por duas diferentes vias - setor público privado. Sendo que os esforços do setor privado iam de encontro, principalmente, a angariação de fundos para salvar edifícios significativos às comunidades. Já os esforços governamentais concentravam-se na proteção de parques, paisagens e recursos naturais. Essas duas vias começaram a se encontrar, finalmente, em 1949, através da formação de uma organização quase-pública, o National Trust for Historic Preservation ${ }^{24}$ (NTHP) (FOWLER,1976).

O National Trust tinha dentre suas atribuições assumir a responsabilidade de propriedades problemáticas para o NPS. As propriedades, normalmente, eram doadas em conjunto com um montante em dinheiro para sua salvaguarda. Contudo, ao longo dos anos, os custos de manutenção ultrapassaram tranquilamente este montante, fazendo com que o NTHP avaliasse cuidadosamente todas as ofertas de doações de propriedades. Os critérios desenvolvidos pelo National Trust for Historic Preservation para avaliação de propriedades fizeram com que este se transformasse em um influenciador na expansão das definições do que poderia ser preservado (LIGIBEL et al., 2000).

Em meados de 1960, a preservação no país sofreu um grande impacto devido as obras de modernização do pós-guerra. No contexto da Guerra Fria, a administração Eisenhower - gestão 1953 -1961 - lançou programas de obras públicas que financiaram a construção de um sistema defensivo de autoestradas interestaduais, que cortavam o país destruindo tecidos históricos urbanos (BOYTON, 2004). É também neste período que a lei nacional de habitação passa por sucessivas modificações e começa a considerar projetos de renovação e conservação urbana menos destrutivos. O governo federal passa a financiar estudos pioneiros na área da preservação histórica e de reabilitação de edifícios, envolvendo os regulamentos do zoneamento, com a participação de organizações sem fins lucrativos e a concessão

24 A criação do National Trust foi proposta como um projeto de lei ao Congresso, H.R. 5170, apresentado pelo deputado J. Hardin Peterson da Flórida. E aprovada através da Public Law No. 81408, 63 Stat. 927, 1949 (FINLEY, 1965). 
de benefícios através de fundos rotativos ${ }^{25}$. Estes estudos serviram de modelo para muitos programas atuais de conservação nas cidades norte-americanas (STIPE, 2003).

A renovação urbana ocorrida em 1960 provocou um novo senso de urgência sobre a necessidade do governo federal estabelecer programas de preservação, visto que somente o Departamento de Habitação e Urbanismo tinha se debruçado sobre a questão até aquele momento. Em 1965, um Comitê especial sobre Preservação Histórica ${ }^{26}$, encabeçada pelo National Trust for Historic Preservation, apresentou um relatório intitulado With Heritage So Rich, composto por uma série de fotografias onde eram dispostas, em grande número, construções históricas que já não existiam mais e, propunha, com isso, que o governo federal criasse um programa de preservação. A resposta do Congresso para este relatório veio com a promulgação da lei intitulada National Historic Preservation Act (NHPA) ${ }^{27}$, em 1966 (E.U.A., 1966).

O NHPA foi responsável por expandir o inventário nacional de bens históricos e culturais, conhecido como National Register of Historic Places, ao incluir, pela primeira vez, bens significativos para as comunidades locais e estaduais. Ele também foi inovador ao disponibilizar fundos para os estados realizarem pesquisas e programas de preservação, assim como, também, providenciou um subsídio de cinquenta por cento para aquisição e preservação de sítios e edifícios históricos sendo que ambas as concessões só seriam disponibilizadas caso cada estado preparasse um plano de preservação, cuja metodologia iremos abordar no Capítulo II. E, como destaque, a Lei de 1966 instituiu um Conselho Consultivo ${ }^{28}$ para fiscalizar as ações da agência federal (E.U.A., 1966).

\footnotetext{
${ }^{25}$ No original: revolving funds. Tal incentivo se constitui como uma conta especial na qual é depositado um montante para despesas sem considerar as limitações impostas pelo ano fiscal. (PICKARD, 2001) ${ }^{26}$ No original: Committee on Historic Preservation. Em 1965, a Fundação Ford deu apoio financeiro a um Comitê especial de Preservação Histórica, este comitê incluia membros selecionados do Congresso e do Conselho de Ministros, representantes da U.S. Conference Mayors, a Liga Nacional de Cidades, a Conferência Nacional de Governadores e uma série de organizações profissionais, lideradas pelo National Trust for Historic Preservation. "A missão do comitê especial era estudar detalhadamente o problema da preservação histórica, comparar as leis e práticas americanas com as européias e preparar um relatório abrangente" (THE COUNCIL, 1986).

${ }^{27}$ Public Law 89 - 665. Washington D.C.,1966. (EUA, 1966)

28 O Advisory Council on Historic Preservation é uma agência federal independente que promove a preservação, aprimoramento e uso produtivo dos recursos históricos da nação americana, e aconselha o presidente e o Congresso sobre a política nacional de preservação histórica. Disponível em: www.achp.gov. Acesso em: 03 ago.2017.
} 
$\mathrm{Na}$ tentativa de encorajar a preservação de propriedades históricas não governamentais o NHPA instituiu um programa federal de subsídios que obrigava os estados a prepararem um plano de preservação para que recebessem as subvenções fiscais. O reflexo dessa iniciativa a nível estadual se deu através do estabelecimento de incentivos financeiros e os estados responderam à lei por diferentes vias, as vezes utilizando programas existentes para a preservação do patrimônio histórico (para cumprir os requisitos do ato de concessão de auxílio) outras criando seus próprios programas, porém pelo ano de 1969 todos os 50 estados tinham designado escritórios estaduais de preservação e estavam participando do programa em algum nível (THE COUNCIL, 1986).

Nos primeiros dez anos da aprovação da lei de 1966, o NPS trabalhou a fim de ampliar o seu quadro de funcionários, para que a agência fosse capaz de implementar os critérios estabelecidos pelo National Historic Preservation Act, assim como expandir o National Register of Historic Preservation de acordo com as novas metodologias para a eleição de bens (STIPE, 2003). A nova lei também diligenciou aos estados que estes formulassem em todo seu território planos de preservação histórica. A princípio os técnicos federais e estaduais pensaram que o trabalho de listagem e nomeação teria um fim após este período inicial de aplicação da lei, e assim eles poderiam se ater a somente manter os edifícios através de restauro e conservação. Contudo, logo ficou claro que este tipo de trabalho não teria fim, visto que a aprovação do NHPA abriu novos campos de pesquisas históricas e arqueológicas e, pela mudança de pensamento no que se viria a ser um bem como patrimônio cultural para a nação norte-americana.

Ao analisarmos a política de preservação nos Estados Unidos buscamos verificar como este país abordou o sistema de financiamento para a conservação de seus bens de interesse histórico. Diferentemente da França, cuja política teve desde os primórdios a preocupação com a questão financeira da preservação do patrimônio edificado, aqui pudemos observar que o Estado norte-americano passa a incentivar o restauro e conservação dos edifícios de interesse histórico somente quando enxerga neste um ativo na economia, porém, desde que os governos estaduais disponibilizem um plano de preservação do patrimônio, o qual iremos analisar no capítulo seguinte. 


\subsection{A invenção do patrimônio histórico nacional}

No Brasil, a intervenção do Estado na preservação do patrimônio cultural se deu, inicialmente, a nível estadual. Bahia e Pernambuco ${ }^{29}$ foram os primeiros estados a aprovarem legalmente a criação de um órgão governamental de proteção ao patrimônio. Contudo, as medidas adotadas por estes não foram suficientes para assegurar a proteção dos monumentos históricos e artísticos visto que, em meados de 1928, o direito de propriedade mantinha-se assegurado em sua plenitude pela Constituição de $1891^{30}$. E, não obstante, o Código Penal corrente não estabelecia sanções para os atentados que fossem cometidos contra a integridade do patrimônio, contrariando assim o que dizia a legislação dos dois estados (SPHAN, 1980).

A primeira lei federal de proteção ao patrimônio foi aprovada num período conturbado, tanto mundialmente, quanto a nível nacional. Em 1929, estourava a crise mundial causando um forte impacto na economia e na política brasileira (FAUSTO, 2003). O país, que passava por uma série de conflitos políticos cujo desfecho foi a Revolução de 1930, e o fim do governo oligárquico, aprova neste mesmo ano um decreto ${ }^{31}$ instituindo um governo provisório. E três anos após, em julho de 1933, eleva a cidade de Ouro Preto a categoria de Monumento Nacional ${ }^{32}$ (BRASIL, 1933).

Ouro Preto, antiga capital do estado de Minas Gerais, foi eleita como monumento por ter sido palco de acontecimentos de grande relevância na história do país e, cujos templos e edifícios de arquitetura colonial, como verdadeiras obras de arte que eram, e ainda o são, mereciam defesa e conservação (Id., 1933). Porém, este mesmo decreto, em seu artigo $1^{\circ}$ estipulou que a eleição desta cidade a monumento nacional não acarretaria em ônus para a União Federal, deixando assim, a critério do estado e da municipalidade a realização de acordos com as autoridades eclesiásticas para efeito de obras de manutenção e conservação dos bens.

\footnotetext{
29 BAHIA. Lei estadual $n \div 2.031$ e 2.032 , de 08 de agosto de 1927 , regulamentadas pelo decreto $n=$ 5.339 de dezembro de 1927, criando a Inspetoria Estadual de Monumentos Nacionais anexa à diretoria do arquivo Público e Museu Nacional. E Pernambuco, com a Lei estadual nำ1.918, em 24 de agosto de 1928, que autorizou o governador do Estado a criar a Inspetoria Estadual de Monumentos Nacionais e um museu (CHUVA, 2009).

30 Constituição da República dos Estados Unidos do Brasil. (BRASIL, 1891)

31 Decreto 19.398, de 11 de novembro de 1930. (BRASIL, 1930)

32 Decreto 22.928 de 12 de julho de 1933. (BRASIL, 1933)
} 
Apesar do decreto delegar ao Estado de Minas Gerais e, para a municipalidade de Ouro Preto, a tutela da cidade histórica, atentamos para o fato de que ambos não dispunham, nos anos de 1933, de um serviço de proteção de monumentos para coordenar qualquer obra referente à matéria. Somente em 1934, um ano após a eleição da cidade, o governo federal provisório organizou um serviço de proteção aos monumentos históricos através do Decreto №24.735, de 14 de julho de 1934 (BRASIL, 1934). Subordinada ao Museu Histórico Nacional a Inspetoria de Monumentos Nacionais tinha como função:

Art. 1으 O Museu Historico Nacional, dependente do Ministerio da Educação e Saude Publica, terá por fim:

a) recolher, classificar e expôr ao público objectos de impartancia historica e valor artistico, principalmente os relativos ao Brasil;

b) concorrer por meio de cursos, conferencias, comemurações e publicações para o conhecimento da história patria e o culta das nossaas tradições;

c) exercer a inspecção dos Munumentos Nacionaes e do commercio de objecto artísticos historicos.

Paragrapho unico. Para os fins da inspecção, organizará um catalogo dos edificios de assignalado valor o interesse artistico-historico existentes no paiz, propondo ao Governo Federal os que se devam declarar em decreto Monumentos Nacionaes; entrará em entendimento com os governos dos Estados, no sentido de se uniformizar a legislação sobre a protecção e conservação dos Monumentos Nacionaes, guarda e fiscalização dos objectos historico-artisticos, de maneira a caber aos Estados os encargos desse serviço nos respectivos territorios. (BRASIL, 1934, online)

O Decreto n-24.735 foi responsável por regulamentar uma nova organização para o Museu Histórico Nacional. E, neste âmbito, criou a Inspetoria de Monumentos Nacionais que já nasceu com orçamento escasso visto que a legislação logo de início estabelecia que "fica aprovado, sem aumento de despesa ${ }^{33}$, o novo regulamento do Museu Histórico Nacional [...]". Significando que as atribuições e obrigações aumentariam, mas o orçamento continuaria o mesmo. $\mathrm{E}$, com isso, entendemos que a Inspetoria de Monumentos não seria beneficiada com orçamento que contemplasse a conservação e manutenção dos bens eleitos, sendo este, provavelmente, um dos

${ }^{33}$ Grifo da autora. 
motivos, de se delegar a tutela de Ouro Preto para o estado e a municipalidade (BRASIL, 1934).

Em 16 de julho de 1934, a Assembleia Constituinte promulgou a constituição da República, a qual dedicava seu capítulo II à educação e a cultura:

Art. 148 - Cabe à União, aos Estados e aos Municípios favorecer e animar o desenvolvimento das ciências, das artes, das letras e da cultura em geral, proteger os objetos de interesse histórico e o patrimônio artístico do País, bem como prestar assistência ao trabalhador intelectual. (BRASIL, 1934,online)

Consagrava-se, assim, no Brasil, como princípio fundamental, a proteção ao patrimônio histórico. Porém, ainda era necessária uma legislação federal adequada para normatizar esta proteção, pois o decreto $\mathrm{n}$ 24.735 consistia em norma apenas regulamentar.

A Inspetoria pode ser considerada como o primeiro órgão nacional de preservação do patrimônio cultural brasileiro até a criação do Serviço do Patrimônio Histórico e Artístico Nacional (SPHAN) ${ }^{34}$, em 1937. A elaboração do órgão de preservação se deu num momento em que o Ministério de Educação e Cultura (MES) era objeto de reformulação, e Gustavo Capanema, à frente do ministério nesse período, aproveitando o ensejo, solicitou a Mário de Andrade a concepção de um anteprojeto $^{35}$ que delineasse a construção do novo órgão federal de preservação. A escolha de Mário de Andrade para realizar tarefa de tal porte era fundamentada no trabalho excepcional que o mesmo vinha realizando a frente do Departamento de Cultura de São Paulo, bem como por seu afamado conhecimento intelectual (CHUVA, 2009).

O anteprojeto de Mario de Andrade conciliava a experiência internacional com peculiaridades brasileiras na formulação de um Serviço do Patrimônio Artístico Nacional (SPAN) ${ }^{36}$. Com o documento em mãos, o ministro solicitou à Câmara a

\footnotetext{
${ }^{34}$ BRASIL. Lei no 378, de 13 de janeiro de 1937. Rio de Janeiro, 1937.

35 "A proposta de Mário de Andrade em seu anteprojeto de criação do Serviço do Patrimônio Artístico Nacional era de âmbito bastante extenso, tentando preservar a totalidade de nossos bens culturais, inclusive hábitos, crendices, cantos, lendas e superstições populares. Mário entendia que arte é uma palavra geral, que nesse seu sentido geral significa a habilidade com que o engenho humano se utiliza das ciências, das coisas e dos fatos". (SALA, 1990)

${ }^{36}$ No anteprojeto elaborado por Mário de Andrade o órgão de preservação seria chamado de Serviço do Patrimônio Artístico Nacional (SPAN) (ANDRADE, 2002).
} 
aprovação de uma emenda incluindo o SPAN na estrutura do MES. O órgão começa a funcionar experimentalmente em 1936, e foi consolidado em 13 de janeiro de 1937, através da lei no 378 - art. 46, que também foi responsável pela criação do Conselho Consultivo do SPHAN ${ }^{37}$. Esta lei foi responsável ainda por autorizar o Executivo, no ano de 1937, a destinar verbas, dentro do orçamento do MES, para implantação do órgão. (CHUVA, 2009)

Art.119 - I) com as despesas de material necessario ao Instituto Nacional de Pedagogia, ao Instituto Nacional de Cinema Educativo, ao Serviço do Patrimonio Historico e Artístico Nacional ${ }^{38}$, ao Museu Nacional de Bellas Artes, ao Instituto Cayrú e ao Serviço de Radiodiffusão Educativa, respectivamente, as quantias de 250:000\$, 400:000\$, 300:000\$39, 100:000\$000, 50:000\$000 e 50:000\$000 [...] (BRASIL, 1937,n.p.)

Comparando a quantia orçamentária destinada ao Serviço de Radiodifusão Educativa, no ano de 1937, com a quantia reservada ao Serviço do Patrimônio Artístico e Nacional, podemos vislumbrar a posição que este órgão ocuparia dentro do ministério e a importância que o governo concederia, a princípio, para as questões que ali seriam tratadas. Observando ainda que, uma cidade histórica já constava como monumento nacional, logo, seria de esperar que o órgão nascesse com uma dotação orçamentária voltada a contribuir com os custos de manutenção e conservação daquela que foi eleita monumento da nação (BRASIL, 1937).

O maior entrave para aprovação de uma lei federal de tutela do patrimônio era a questão do direito de propriedade. As primeiras iniciativas de preservação do patrimônio cultural foram delineadas a partir de conceitos e disciplinas - arte, história, arqueologia -, através de uma distribuição geográfica do que se queria preservar (RUBINO, 1992, p.33). Porém, tiveram pouca ou nenhuma eficácia concreta, visto que eram inconstitucionais no que se referia ao direito de propriedade, bastante definido nas normas vigentes da época. No dia 10 de novembro, enquanto a lei federal que viria a ser o Decreto-Lei nำ25/1937 estava na Câmara para votação final, com as emendas já realizadas pelo Senado, foi realizado um golpe de estado, dissolvendo o

${ }^{37}$ Com a aprovação da Lei no 378 , de 13 de janeiro de 1937 cuja concepção foi um tanto diversa daquela proposta por Mário de Andrade, a categoria histórica foi incluída na nomenclatura, passando o órgão a se chamar Serviço do Patrimônio Histórico e Artístico Nacional (CHUVA, 2009).

38 Grifos da autora.

39 Lê - se: trezentos contos de réis. 
Congresso Nacional, e promulgada uma nova Constituição, esta possibilitou a aprovação da lei federal de proteção aos imóveis tombados. ${ }^{40}$ (SPHAN, 1980).

Mário de Andrade, em seu anteprojeto (1936) para a criação do Serviço do Patrimônio Artístico e Histórico Nacional (SPHAN), foi o responsável pela introdução do termo "tombamento" no patrimônio cultural brasileiro. Pois nas normativas internacionais os termos "classificação" e "catalogação" eram, à época, e são até hoje, recorrentemente utilizados (SALA,1990). O Decreto-Lei no25 de 1937, instituiu o tombamento como instrumento de reconhecimento e proteção do Patrimônio Cultural do Brasil. Contudo, deve-se dissociar a ideia de que as bases legais, administrativas e teóricas deste teriam sido formuladas no anteprojeto de Mario, pois a normativa brasileira referente a este assunto provinha de uma trajetória jurídica e conceitual anterior ${ }^{41}$ (CHUVA; NOGUEIRA, 2012).

O Decreto-Lei no25/1937 pela sua subjetividade ao definir o que constituía patrimônio cultural expande o leque para inclusão de quaisquer tipos de bem móvel ou imóvel a virem ser objeto de tombamento:

Art. $1^{\text {0 }}$ - Constitue o patrimônio histórico e artístico nacional o conjunto dos
bens móveis e imóveis existentes no país e cuja conservação seja de
interêsse público, quer por sua vinculação a fatos memoráveis da história do
Brasil, quer por seu excepcional valor arqueológico ou etnográfico,
bibliográfico ou artístico. (BRASIL, 1937, online)

Se aproximando com este aspecto da legislação francesa de 1913, onde os imóveis passíveis de proteção eram aqueles que apresentavam "um interesse público do ponto de vista histórico ou artístico" (FRANÇA, 1913, n.p.). Ou seja, qualquer imóvel, independentemente de sua ancianidade ou natureza, poderia ser protegido pela lei.

$\mathrm{Na}$ França, com a aprovação da lei de 1913, o Estado passou a financiar 50\% das obras de restauração dos imóveis "classificados", já no caso brasileiro, o DecretoLei no25/1937 estipulava que o proprietário que não dispusesse de recursos para

\footnotetext{
40Decreto-Lei no 25, de 30 de novembro de 1937 (BRASIL, 1937).

${ }^{41}$ A proposta pioneira de defesa de bens culturais partiu do Instituto Histórico e Geográfico da Bahia, através de seu sócio, Wanderley Pinho, em 1917. Em 1920 o Professor Alberto Childe, conservador de Antiguidades Clássicas do Museu Nacional, a pedido de Bruno Lobo, então presidente da Sociedade Brasileira de Belas Artes, elaborou um anteprojeto de lei de proteção ao Patrimônio Histórico do País (CHUVA; NOGUEIRA, 2012).
} 
garantir a conservação do bem poderia solicitar ao SPHAN o financiamento das obras. Contudo, a escolha do bem a ter seu restauro financiado ficou a preceito do SPHAN, já que o decreto não estipulava critérios para o procedimento, abrindo caminho, assim, para tratamentos diferenciados na escolha dos bens cujas obras seriam financiadas pelo estado (CHUVA, 2009).

Anos mais tarde, um novo Decreto-Lei ${ }^{42}$ dispôs sobre a questão financeira dos monumentos e obras de valor artístico e histórico existentes no Brasil. Segundo esta legislação o SPHAN ficava autorizado a receber doações a título de contribuição, por iniciativa particular, para realizar trabalhos referentes a salvaguarda, conservação e restauração. (BRASIL, 1940) Um ponto a destacar neste Decreto-Lei era o fato do doador poder determinar a destinação da verba,

[...] o capital (econômico e simbólico) do doador se sobrepunha ao interesse público, que, segundo o próprio discurso instituinte das práticas do SPHAN, deveria ser o único capaz de decidir o que deveria ser priorizado nas ações conservação e/ou restauração [...] (CHUVA, 2009, p.174).

Durante os trinta primeiros anos do Serviço do Patrimônio ${ }^{43}$, foram aprovadas leis referentes à desapropriação, conservação de acervos, monumentos arqueológicos e pré-históricos dentre outras. Esta primeira fase do órgão é marcada por intensa atividade em favor dos bens culturais isolados. $\mathrm{E}$ no que diz respeito ao financiamento da conservação desses bens, algumas particularidades foram observadas quanto ao tratamento dado aos proprietários dos imóveis.

Os maiores beneficiários de financiamentos do Estado através da pessoa do SPHAN foram as municipalidades e a Igreja, estes não encontravam grandes entraves quando solicitavam financiamento de obras em suas propriedades. Já no caso do proprietário privado, salvo nas raras ocasiões em que o próprio SPHAN tomava frente na consecução da obra, este encontrava muitos impedimentos ao solicitar financiamento federal para obras de conservação e/ou restauro, sendo obrigado a aceitar o restauro conforme ditava as regras do SPHAN naquele momento, ou seja, a obra deveria contemplar a visão que o SPHAN queria para aquele imóvel. Não

\footnotetext{
${ }^{42}$ Decreto-lei no 2.809 de 23 de novembro de 1940 (BRASIL, 1940).

${ }^{43}$ Em 1946 o Serviço do Patrimônio Histórico e Artístico Nacional passar a ser chamar Diretoria do Patrimônio Histórico e Artístico Nacional (DPHAN), através do decreto-lei ํㅜ 8.534, de 4 de janeiro de 1946 (BRASIL, 1946)
} 
importando se este fosse um estado que jamais tivesse existido naquela construção (CHUVA, 2009).

Nos anos subsequentes à 1967, os trabalhos do DPHAN ${ }^{44}$ passam a ter uma orientação voltada a preservação de conjuntos históricos. A expansão viária, consequente da rápida industrialização, influenciou no crescimento acelerado e desordenado das cidades e, sobretudo, na valorização imobiliária decorrente desse processo. Todos estes fatores impuseram a implementação de medidas mais enérgicas e abrangentes no âmbito da preservação do patrimônio (DEAK; SCHIFFER, 2015). "Procurou-se, a partir de então, conciliar a preservação dos valores tradicionais com o desenvolvimento econômico das regiões." (SPHAN, 1980, p.19).

Contudo, a preservação destes conjuntos históricos era ameaçada, devido, também, aos critérios de seleção utilizados pelo DPHAN. Pois a arquitetura menor, aquela sem os atributos da "arquitetura tradicional" 45 não era digna de um tombamento, ficando assim desprotegida e, consequentemente, abrindo brechas para a destruição de núcleos com significância histórica a nível local. No princípio de 1970, começa a surgir uma revisão desta postura supressora sob influência de um novo conceito: o patrimônio ambiental urbano ${ }^{46}$. Este entendia que, a arquitetura menor era portadora de características que agregavam significância quando visualizadas no âmbito de um conjunto (YÁZIGI, 1977).

O novo conceito nasceu com alguns entraves, o primeiro dizia respeito ao método realizado para estudá-lo e classificá-lo. Pois o conjunto que compunha o patrimônio ambiental urbano deveria dispor de um dispositivo de eleição diferente daqueles utilizados para os elementos históricos que eram escolhidos singularmente e, para isso, seria necessário a concepção de uma metodologia que pudesse abarcar

\footnotetext{
44 Através do Decreto-lei ํ․ 8.534, de 02 de janeiro de 1946, o Serviço do Patrimônio Histórico e Artístico Nacional (SPHAN), criado em 1937 pela Lei $n^{\circ}$. 378, de 13 de janeiro, foi transformado em Diretoria do Patrimônio Histórico e Artístico Nacional (DPHAN).

${ }^{45}$ RODRIGUES, M. Imagens do passado: a instituição do patrimônio em São Paulo (1969 - 1987). São Paulo: Editora UNESP, 2000.

${ }^{46}[. .$.$] é fundamentalmente composto de uma grande massa de elementos típicos, normais, comuns,$ cotidianos que, eles sim, representam alguma coisa no contexto urbano. Os bens históricos e artísticos quase todos são exceção. Percebemos que um dos interesses maiores quanto à conservação do patrimônio ambiental urbano é a conservação da inteligibilidade do espaço urbano, a compreensão da cidade, a leitura da cidade. (LEMOS, 1979, p. 9) O conceito de patrimônio ambiental urbano foi trazido a São Paulo em virtude de um curso realizado na Faculdade de Arquitetura e Urbanismo da Universidade de São Paulo pelo arquiteto francês Varine - Bohan, em 1974 (BAHFI,2015).
} 
todos os elementos que compunham a paisagem. A listagem surge dessa necessidade em catalogar todos os bens que compunham esta nova perspectiva.

O segundo entrave referente à instituição da paisagem ambiental urbana dizia respeito à sua validação jurídica, visto que o instrumento do tombamento era deficiente para reconhecer todos os elementos que compunham a paisagem. Mas esta é uma questão que até os dias atuais ainda não foi elucidada e este foi um dos motivos ao qual nos propusemos a analisar o Secteur Sauvegardé e a Zone de Protection du Patrimoine Architectural, Urbain et Paysager (ZPPAUP) franceses pois, entendemos que ambas propostas podem contribuir na discussão acerca do melhor método para reconhecimento legal de uma paisagem ambiental urbana.

\subsection{O patrimônio cultural e o desenvolvimento urbano: antecedentes da preservação na Cidade de São Paulo}

Em São Paulo, a listagem foi utilizada pela primeira vez num trabalho organizado pela Coordenadoria Geral de Planejamento (COGEP), em 1974. Responsável por contratar os arquitetos Carlos Lemos e Benedito Lima de Toledo para realizar um inventário do centro comercial, que naquela época se localizava no atual centro histórico da cidade, sob o ponto de vista artístico-histórico ${ }^{47}$ (CJ ARQUITETURA, 1977). A cidade, na pessoa da gestão política do momento, que naquele período passava por grandes obras devido ao crescente aumento populacional, expansão rodoviária e as demandas que dela surgiam não tinha conhecimento dos exemplares arquitetônicos que acumulou durante os seus quatrocentos anos de existência. Sendo assim, por demanda do prefeito Miguel Colassuono, a Coordenadoria Geral de Planejamento (COGEP), coordenadoria vinculada diretamente ao gabinete da prefeitura, tomou a iniciativa neste trabalho pois

\footnotetext{
47 O levantamento foi realizado no âmbito do "Projeto Centro: investigações preliminares", que se tratava de habitação, transporte, áreas verdes e bens culturais (SOMEKH, 2015).
} 
o município de São Paulo ainda não dispunha, naqueles anos, de um órgão de preservação do patrimônio a nível municipal ${ }^{48}$.

Lemos e Toledo ${ }^{49}$, foram os profissionais contratados para realizar este cadastro que posteriormente se tornaria uma listagem e empreenderam o trabalho sob dois enfoques: o primeiro econômico e, o segundo relativo às técnicas construtivas. $O$ trabalho, assim como o inventário das riquezas gerais da França, foi produzido enfocando a criação de manchas urbanas, estas tanto englobavam "exemplares arquitetônicos representativos como também agenciamentos do sistema viário a eles contemporâneos e, ainda, aspectos pertinentes à adaptação ao sítio de instalação, onde se percebia a sujeição da cidade aos acidentes geomorfológicos" (CJ ARQUITETURA, 1977, p.25).

Foram também produzidas manchas relacionadas aos aspectos socioeconômicos, à estrada de ferro, as vilas operárias e a imigração. Finalizado em 1975, ano de mudança na gestão política da cidade, o trabalho foi arquivado, porém a gestão municipal sofreu duras críticas por esta atitude, e, com forte apoio da mídia e de setores da sociedade, o inventário realizado pelo COGEP, em 1975, foi sancionado na Câmara Municipal através da Lei no 8.328 de 20 de dezembro de 1975, significando que, daquele ponto em diante, quaisquer obras de intervenção nos imóveis ali listados deveriam passar pelo conhecimento da COGEP, pois o CONPRESP (Conselho Municipal de Preservação do Patrimônio Histórico, Cultural e Ambiental da Cidade de São Paulo) seria criado somente em $1985^{50}$ (CJ ARQUITETURA, 1977).

As questões relativas à preservação do patrimônio em São Paulo, já haviam sido objeto de interesse quando da criação do Departamento de Cultura e Recreação em 1935, contudo este Departamento não realizou um inventário dos bens imóveis significativos como aquele solicitado à COGEP. Mário de Andrade, a frente do Departamento entre 1935 e 1938, buscou, através de intensos estudos e pesquisas,

48 O CONDEPHAAT foi criado pela Lei 10.247 da Constituição de 1967 do Estado de São Paulo (art. 128), que dispunha sobre sua competência, organização e funcionamento. No ano de 1968 foi promulgado o Decreto 149 que dispôs sobre o tombamento de bens de valor histórico e artístico.

${ }_{49}$ Carlos Lemos e Benedito Lima de Toledo, ambos arquitetos e professores da Universidade São Paulo.

50 O CONPRESP tem entre suas atribuições deliberar sobre o tombamento de bens móveis e imóveis de valor reconhecido para a Cidade de São Paulo (SÃO PAULO, 1985). 
abarcar todas as formas de manifestações culturais, não se atendo somente aos edifícios de valor estético e/ou artístico imensuráveis. Mas sim, procurou conhecer e preservar, através de documentações escritas, fotográficas e gravações de áudio, todas as formas de fazer e saber dos paulistanos. E teve, para isso, grande apoio do prefeito, visto que $10 \%$ do orçamento da prefeitura era destinado ao Departamento de Cultura, diretamente subordinado àquele gabinete (CALIL; PENTEADO, 2015). No que se refere à preservação de edifícios os primeiros atos se deram em $1947^{51}$, quando o Departamento de Cultura passou a ser subordinado à Secretaria de Educação e Cultura, através da Divisão do Arquivo Histórico onde foi realizada a preservação das casas bandeiristas do Butantã e do Caxingui.

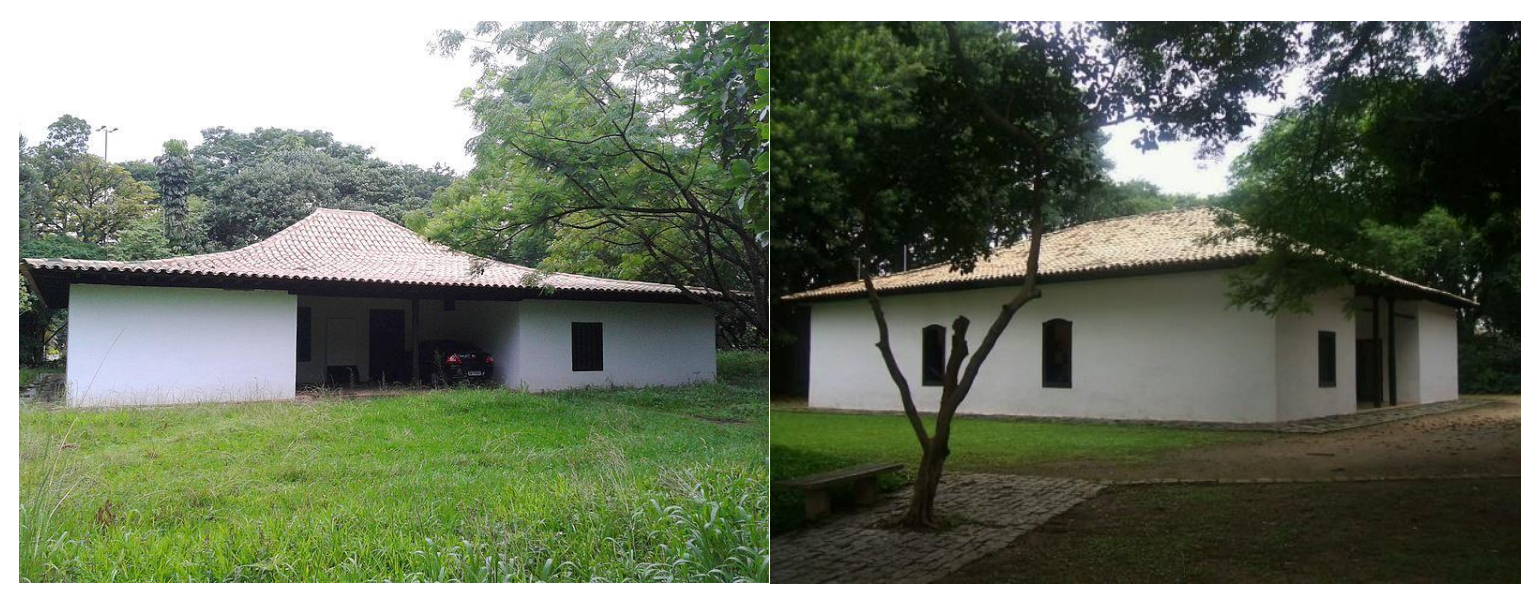

Figura 1.2 - Casa do Caxingui (à esquerda) e Casa do Butanta (à direita). Fonte: Departamento do Patrimônio Histórico de São Paulo, 2015.

"Em 1974 o prefeito Miguel Colasuono enviou à Câmara Municipal um Projeto de Lei (192/74) visando à criação de uma Secretaria Municipal especialmente dedicada à questão da cultura, desmembrando em duas - Secretaria de Educação e Secretaria de Cultura - a então Secretaria de Educação e Cultura. Nas justificativas, explicava-se que a gestão de assuntos tanto do campo artístico-cultural como do campo do ensino e da recreação havia se tornado complexa demais para continuar sob a responsabilidade de apenas uma pasta" (MAYUMI, 2008, p. 156).

51 O Departamento de Cultura e Recreação foi criado em 1935 através do Acto no61 de 30 de maio de 1935 e era subordinado diretamente ao gabinete do Prefeito. Em 1945 através do decreto-lei nํ33 o departamento passa a ser subordinado à Secretaria de Cultura e Higiene. Dois anos após, com o decreto-lei no 430, o Departamento de Cultura ficaria alocado na Secretaria de Educação e Cultura. 
O Departamento do Patrimônio Artístico- Cultural ${ }^{52}$ foi criado em 1975, quando a Lei $n^{\circ}$ 8.204/75 instituiu a cisão da Secretaria de Educação e Cultura, originando com isso a Secretaria Municipal de Educação e a Secretaria Municipal de Cultura (SMC) e, atrelado a segunda, o órgão municipal de preservação do patrimônio (SÃO PAULO, 1975). O recém-criado Departamento, não teve atuação pois passados dois meses de existência sofreu reformulação administrativa, após análise dos assuntos que este iria tratar entendeu-se que era conveniente separar áreas de atuação tão especializadas. Sendo assim, em 20 de maio de 1975 foi criado o Departamento do Patrimônio Histórico (DPH) que tinha dentre suas atribuições a realização de levantamento, cadastramento, preservação e finalização de obras e monumentos artísticos do Município, e a mesma lei criou ainda o Departamento de Informação e Documentação Artísticas (IDART). ${ }^{53}$

Ao IDART, coube a tutela sobre os bens relativos ao acervo de arte contemporânea e, ao DPH, a guarda dos bens patrimoniais ligados à história, bem como a proteção dos museus históricos, das obras de arquitetura e de arte do passado. Essa foi a justificativa constante no Projeto de Lei $n^{0} 44-45 / 75^{54}$, para o desmembramento do Departamento do Patrimônio Artístico-Cultural em dois novos Departamentos. A Lei no 8.252/75 foi promulgada cinco meses após a sanção da lei anterior, já na gestão do Prefeito Olavo Setúbal.

Os primeiros trabalhos do DPH foram concentrados em ações de conservação de monumentos arquitetônicos ${ }^{55}$, encabeçando a lista estavam os bens culturais imóveis de propriedade do município, ou protegidos por lei federal, estadual ou municipal. Outros imóveis correlatos foram gradualmente transferidos, por compra, doação ou desapropriação à Secretaria, adotando, resumidamente, os seguintes passos:

52 O Departamento do Patrimônio Artístico - Cultural deveria executar todas as políticas municipais referentes à monumentos artísticos, museus e documentos. Também seria responsável por realizar pesquisas sobre cultura e arte além de organizar exposições (Processo Municipal 50.043/74).

${ }^{53}$ Segundo Murilo Marx, Maria Eugenia Franco foi a responsável por criar o DPH, assim como o IDART. Pois ela, ex-funcionária do Departamento de Cultura de São Paulo, idealizado e dirigido (entre 1930 e 1935) pelo famoso escritor Mário de Andrade, foi quem esquematizou, nos moldes do organograma do antigo Departamento, a Secretaria Municipal de Cultura (MAYUMI, 2005).

${ }^{54}$ Processo Municipal 29.735/75. Desmembramento do Departamento do Patrimônio Artístico - Cultural (São Paulo, 1975).

${ }^{55}$ As casas históricas, já citadas, do Butanta e Caxingui, assim como outras que estavam sob tombamento do IPHAN ou eram objeto de preservação por parte da Divisão do Arquivo Histórico (MAYUMI, 2008). 
a) declarar-se de "utilidade pública" o imóvel particular; b) desapropria-se o imóvel, mediante pagamento de indenização ao proprietário, pelo município. O imóvel fica classificado como "bem comum de uso do povo"; c) desincorpora-se o imóvel da classe de "bens de uso do povo" e se incorpora-o como "bem patrimonial" do município; d) o Poder Executivo recebe o "bem patrimonial" em doação; e) o Poder Executivo transmite à Secretaria Municipal de cultura o "bem patrimonial". Na Secretaria de Cultura, em conformidade com a lei que a criou, os edifícios históricos ficam sob tutela do DPH. (MAYUMI, 2008, p. 160)

A orientação inicial do novo órgão partia para uma aproximação abrangente do patrimônio cultural, contudo a prática demonstrou outro funcionamento. A conjunção entre o trabalho que se pretendia desenvolver e a estrutura interna do órgão, que aqui não nos cabe delinear visto que não é o objetivo do presente trabalho, sempre estiveram em desacordo segundo entrevista realizada por Mirthes Bhafi ao $\mathrm{DPH}^{56}$ (DPH, 2015). O órgão que se pensou moderno desde o princípio, que intentava discutir a cidade, iniciou seus trabalhos conservando os imóveis isolados já tombados pelo IPHAN, cujas diretrizes de restauro, apesar de não compartilhadas totalmente do ponto de visto conceitual, nesta fase inicial, foram acatadas pelo órgão municipal (MAYUMI, 2008; CHUVA, 2009).

Conforme já discorremos na página 37 deste capítulo, os maiores beneficiários dos financiamentos do Estado para obras de restauro foram as municipalidades e a Igreja, sendo que, os proprietários privados que solicitassem recursos deveriam concordar com os padrões impostos pelo IPHAN. Pensamos, apesar de não termos comprovado pela falta de material, que a imposição dos padrões impostos também alcançava as obras municipais que fossem custeadas com verbas do governo federal através do Instituto do Patrimônio Artístico e Histórico Nacional e este foi um dos fatores pelo qual as diretrizes de restauro foram acatadas pelo órgão municipal. E, aliado a isto, havia ainda o fato do DPH ter adotado no início de seus trabalhos uma postura colaborativa de trabalho frente aos órgãos federal e estadual (DPH, 2005; CHUVA, 2009).

[...]O município, a obrigação dele é, como as várias constituições falam, colaborar nas coisas específicas, por exemplo, saúde pública, com a esfera

\footnotetext{
56 [...] "a prática era dentro de uma visão moderna de patrimônio e a estrutura era dentro de uma visão antiga de patrimônio." (DPH, 2015, n.p.)
} 
estadual e com a esfera federal. Que folhas de trabalho maiores que existem? Nenhuma maior que do IPHAN no Rio, ainda sediado no Rio. Não há o que discutir, é lá que está todo manancial não só de preservação como de história da arte, de questões de estética, de questões de restauração, de discussões...é lá57. (MAYUMI, 2005)

Em 1976, o Departamento do Patrimônio Histórico passa a trabalhar em conjunto com a COGEP e por demanda do novo coordenador deste órgão, Candido Malta Campos Filho, foi realizada uma ampliação da primeira listagem. Neste segundo trabalho é empreendida uma abordagem do edifício não só sob o ponto de vista externo, como fora feito anteriormente, mas também internamente. Este trabalho foi importante já que nele os arquitetos Carlos Lemos e Benedito de Toledo puderam avançar em relação à identificação de bens culturais, formulando um instrumento que contribuiria para a conservação do patrimônio histórico (CJ ARQUITETURA, 1977).

A Transferência do Direito de Construir ${ }^{58}$ (TDC) foi o instrumento pensado pelos dois arquitetos, como aquele que poderia vir a contribuir com a preservação do patrimônio da cidade. Carlos Lemos e Benedito Lima de Toledo haviam participado de muitas conferências que ocorriam naquela época para discutir o Solo Criado, o primeiro instrumento do qual derivou a TDC, e que era o assunto em pauta no meio dos urbanistas. A experiência francesa com a aplicação do Plafond Legal de Densité59 (PLD) e a experiência norte-americana com o Space Adriff $f^{60}$, este direcionado exclusivamente aos bens preservados, suscitaram discussões acerca do tombamento e sua decorrência aos proprietários do imóvel tombado, bem como sua influência na economia das cidades. Contudo, a TDC só viria a ser regulamentada em 1984, pela Lei oㅜ 9.725 .

\footnotetext{
${ }^{57}$ Relato do arquiteto Murilo Marx, primeiro diretor do Departamento do Patrimônio Histórico, em entrevista concedida a arquiteta Lia Mayumi (MAYUMI, 2005).

${ }^{58}$ Aqui chamamos o instrumento de Transferência do Direito de Construir pois foi com esta terminologia que ele surgiu quando das discussões do Solo Criado, para maiores detalhamentos verificar o capítulo terceiro deste trabalho.

59 Lei que limita o direito de construção a uma vez a área do terreno, definindo um teto legal de densidade, através da Lei no 75-1328 de 31 de dezembro de 1975 ("Code de l'Urbanisme" art. 112) (CIPRIANO, 2016).

60 "Em 1973, no Plano para a Cidade de Chicago foi proposto um instrumento, o Space Adrift. Traduzido literalmente para espaço flutuante, foi formulado como parte de uma política de preservação, previa o conceito da transferência do direito de construir. Os terrenos que abrigassem imóveis preservados como patrimônio histórico e cultural, poderiam transferir o seu potencial construtivo para outras zonas da cidade onde a legislação limitava a construção" (CIPRIANO, 2016).
} 
Vimos, então, que as principais ações do DPH se concentraram em conservar imóveis já tombados e que eram propriedade do município e, os que ainda não eram e passavam a ser. Logo, o órgão de preservação municipal inicialmente não realizou tombamentos, primeiro por ainda não dispor de um conselho que referendasse suas decisões e , segundo, por ter como plano de ação inicial a conservação dos imóveis que representavam o início da história da cidade.

Já a COGEP foi responsável por realizar a listagem que deu origem aos primeiros $^{61}$ imóveis preservados em São Paulo. Posteriormente, quando da ocorrência da segunda listagem, a qual contou com a colaboração do DPH, a coordenadoria, por trabalhar no âmbito urbanístico, visualizou a necessidade de propor instrumentos que balizassem o crescimento da cidade em virtude de suas préexistências, pensando também no ponto de vista do proprietário do bem tombado que no futuro necessitaria de incentivos que contribuíssem para a preservação do imóvel. Foram realizados alguns estudos, que tomaram como referência instrumentos propostos na França e nos Estados Unidos da América, para implementação da TDC nos imóveis classificados como Z8.200 porém este assunto será discutido mais a frente no Capítulo II.

61 Imóveis enquadrados como Z8.200 pela Lei 끈.328, de 2 de dezembro de 1.975 . 
Capítulo II - FRANÇA E EUA, O MODELO INTERNACIONAL COMO REFERÊNCIA? 


\subsection{França: a preservação de conjuntos e edifícios históricos através de projetos.}

A preocupação com as pré-existências e os efeitos por elas sofridos em decorrência da expansão urbana é tema de longa data. Na literatura podemos verificar esta questão já nos escritos de Gustavo Giovannoni (1873-1947), grande teórico no campo do restauro urbano, onde são levantados os conflitos derivados da expansão da cidade e a necessidade de preservar tecidos históricos (GIOVANNONI, 1913 apud KÜHL, 2013). No entanto, foi após a Segunda Guerra Mundial que o debate assumiu maior visibilidade em decorrência das demandas por reconstruções de centros históricos nas cidades europeias, enquanto ao mesmo tempo, nos Estados Unidos da América (E.U.A.), áreas consideráveis de tecidos urbanos históricos foram demolidas para dar lugar a novos traçados de ruas, habitações e espaços de lazer.

As intervenções urbanas na Europa do pós-guerra baseavam-se no planejamento conduzido pelo Estado, e tinham como desafio duas condições opostas para resolver: o desaparecimento dos centros urbanos, dado pelas destruições causadas com a guerra; e a negação da centralidade urbana, devido ao constante alargamento das cidades. No que diz respeito ao tratamento das áreas centrais das cidades, buscou-se abandonar toda sistematização e quantificação de dados utilizados anteriormente à Segunda Guerra Mundial. Representando o colapso da arquitetura moderna, o novo pensamento apresentou-se como uma contra força ao método de planejamento que dividia a cidade em quatro funções - habitação, trabalho, recreação e transporte - e procurou privilegiar os locais onde o sentido de comunidade deveria estar fisicamente expresso, ou seja, o centro (histórico) das cidades (ABRAHÃO, 2008; MARCHI, 2016).

As recuperações dos centros históricos europeus eram focadas, principalmente, nos espaços públicos. Em 1951, o 8 Congresso Internacional de Arquitetura Moderna (CIAM), teve o centro das cidades como tema de discussão, intitulando o evento como The heart of the city62, numa tentativa de recuperar a vida que estes continham antes da Segunda Guerra.

62 O coração da cidade. Tradução da autora. 
Naquele encontro, falou-se das cidades americanas e seus subúrbios, da criação de zonas centrais para pedestres nas cidades inglesas, suecas e holandesas e da importância dos centros históricos das cidades italianas. (MENEGUELLO, 2005, p.02)

O encontro buscou reconhecer o valor das "pré-existências" e do "caráter do lugar", através do resgate do papel da "história" e do "passado", reposicionando-os como personagens vivos do presente e não apenas uma variante dentro do projeto moderno. Josep Lluis Sert (1902-1983) no discurso de abertura chamou atenção para o papel do centro urbano, através do espaço de uso público, na facilitação dos contatos pessoais. A consolidação do que restara no patrimônio urbano nas cidades europeias assim como sua preservação teve o espaço de uso público como agente propulsor (CASTILHO; VARGAS, 2015).

Enquanto isso, nos Estados Unidos da América (E.U.A.) os veteranos da guerra retornavam para suas cidades e levavam consigo o sonho americano: possuir um carro e uma residência unifamiliar implantada em lote individual, longe do congestionamento e demais problemas associados aos centros das cidades. $\mathrm{O}$ governo federal subsidiou esta migração maciça aos subúrbios, através da concessão de incentivos fiscais e baixas taxas de juros e, com o Housing Act, de 1949, iniciou programas de remoção de cortiços das áreas centrais, por meio da demolição de habitações subnormais, que viriam a ser suplantadas por edifícios de escritórios, apartamentos de alto padrão ou, em muitos casos, restariam apenas os terrenos vazios, pois não se configuravam como de interesse do mercado imobiliário (STIPE, 2003).

Aproximadamente setecentos planos para áreas centrais foram elaborados e publicados, até 1959, nos E.U.A., e, muitos destes, defendiam a melhoria de vida nos centros, através da construção de vias urbanas e autoestradas diferentemente da visão europeia onde o espaço público era o principal agente. E, como vimos no capítulo anterior, estas obras públicas financiadas pelo governo federal foram responsáveis pela destruição de grandes áreas de tecido urbano histórico provocando assim a resposta dos órgãos e entidades de preservação com a promulgação de uma ${ }^{l e i^{63}}$ que previa a destinação de recursos financeiros para as cidades que formulassem

63National Historic Preservation Act, U.S.A. Public Law 89 - 665. (EUA, 1966). 
planos de preservação para os locais históricos, incluindo-se área centrais (CASTILHO; VARGAS, 2015).

Apesar de ser mais evidente no caso americano, onde a luta pela preservação dos centros históricos ficou a cargo dos órgãos referentes a este assunto, a dicotomia entre planejamento urbano e a defesa das pré-existências também esteve presente na Europa. Contudo, no caso do continente europeu a questão da preservação estava aliada a manutenção de uma consciência de nação, após uma grande guerra, e de fortalecimento do sentido de pertencimento a um lugar e a um país. A restauração do patrimônio, que na maioria dos casos foi uma reconstrução, obteve, assim, maior atenção.

Após 30 anos, aproximadamente, uma série de movimentos nos quais a estética, o patrimônio e a questão ambiental norteavam o discurso, inaugurou uma nova fase no processo de intervenção em áreas centrais. Essa fase trouxe consigo a negação do movimento anterior, o modernismo e, reforçou a importância da preservação do patrimônio histórico como símbolo de status e distinção. Os projetos desta fase incorporaram antigas estruturas industriais, estações de trem, armazéns, mercados, entre outros; introduzindo nesses espaços áreas de lazer e cultura, em conjunto com serviços e comércios.

Cumpre destacar que neste período surgiu um grande número de normatizações e legislações visando salvaguardar setores e centros históricos. Os órgãos de preservação de diversos países, por meio de cartas, declarações e recomendações, apontaram a necessidade de inclusão da preservação de áreas históricas no âmbito do planejamento urbano, como meio de salvaguardar a vida e integridade das cidades e das pessoas que nelas habitavam. Administrações públicas de diversos países produziram leis, planos e projetos neste sentido, contudo um grande número destes resultou em intervenções isoladas, ou nunca saiu do papel. 


\subsubsection{O Secteur Sauvegardé e a preservação de centros históricos na França.}

Já na década de 1960, a França instituiu um dispositivo para proteger o patrimônio urbano, o Secteur Sauvegardé64. Este instrumento, implantado através da Lei ํㅡ 62-903 de 4 de agosto de 1962, conhecida como "Lei Malraux", nasceu em resposta às operações de renovação urbana, postas em prática pelo decreto de 31 de outubro de 1938, que tratavam do problema de insalubridade em bairros e centros históricos através de demolições. Estes setores tinham ${ }^{65}$ como função preservar a integridade física dos locais históricos, assim como permitir sua reabilitação através da concessão de incentivos fiscais aos proprietários (FRANÇA, 1962).

$\mathrm{O}$ ato que instituiu o setor salvaguardado recomendava a criação de um Plan de Sauvergarde et de Mise en Valeur (PSMV) ${ }^{66}$ sendo que, entre a criação do setor e a publicação do plano, a preservação dos bens patrimoniais contidos no perímetro ficava condicionada à tutela do Architecte des Bâtiments de France $(A B F)^{67}$, responsável pela autorização e fiscalização, durante este período, de todos os projetos referentes às construções e ao espaço público contidos no perímetro. Cumpre ainda destacar que após a aprovação do PSMV, o Plan Local d'Urbanisme ${ }^{68}$ (PLU) poderia sofrer modificações para se ajustar a este e, quando de sua aprovação, o PSMV passava a ser o único documento a regulamentar urbanisticamente aquela área (FRANÇA, 1962).

\footnotetext{
64 Setor salvaguardado. Tradução da autora.

65 Atualmente o Secteur Sauvergadé passou a compor o que na França foi designado como Sites Patrimoniaux Remarquables, conforme designado pela Lei sobre a Liberdade de Criação, Arquitetura e Patrimônio (loi relative à la liberté de la création, à l'architecture et au patrimoine - LCAP) promulgada em 7 de julho de 2016 (FRANÇA, 2016).

66 Plano de Salvaguarda e Valorização. Tradução da autora.

67 O Arquiteto dos Edifícios da França pertence ao corpo de arquitetos e urbanistas do Estado escolhendo a opção "Patrimônio" como especialização de trabalho. Tem como função manter e preservar os monumentos históricos classificados ou inscritos, garantindo a manutenção da qualidade em novas construções e reabilitações perto de monumentos históricos e outras áreas protegidas, desde que, o gerenciamento do projeto tenha ficado sob responsabilidade do Ministério da Cultura ou que os proprietários ou cessionários recebam apoio financeiro do Estado. Tradução da autora. Disponível em: https://lannuaire.service-public.fr. Acesso em: 03 abr. 2017.

68 O Plano Local de Urbanismo (PLU) é um documento estratégico e de regulamentação. Ele é estratégico pois comporta um esquema de orientações sobre a evolução da cidade num horizonte de 10 a 15 anos. E é regulamentador quando rege a evolução de parcelas da cidade através da instrução de permissão de construir e de demolir (FRANÇA, 1978). Tradução da autora.
} 
A elaboração69 do PSMV era realizada pelo Estado em conjunto com a autoridade local, responsável pela elaboração do PLU. Posteriormente, este era submetido à Comissão Local de Preservação do Patrimônio, onde era efetuado um parecer e, se esta comissão recomendasse, o plano deveria ser submetido à aprovação do município ou dos municípios, visto que o setor poderia abranger um perímetro que não se localizasse necessariamente dentro de um município somente. A etapa seguinte se concentraria na submissão do Plan de Sauvergarde et de Mise en Valeur ao órgão deliberativo em matéria de PLU e à Comissão Nacional de Preservação do Patrimônio, onde, posteriormente, deveria ser realizada consulta pública nos moldes de uma enquete à população. Finalmente, após este longo processo, o plano era aprovado pela administração central, esta etapa ocorreria somente se o parecer do órgão deliberativo em matéria de PLU tivesse sido favorável, caso contrário, o PSMV seria aprovado por decreto do Conselho de Estado (FRANÇA, 2017).

O PSMV tinha, por princípio, definir uma política global de valorização para o setor salvaguardado, através da análise da morfologia urbana e das funções urbanas compatíveis com o setor, assim como do estudo das relações entre o setor salvaguardado e sua periferia em termos de habitação, comércio, transportes etc. $O$ plano também era responsável por auferir qual a dinâmica econômica da área em questão, a fim de apontar quais os melhores serviços, instituições e atividades que poderiam ser implantadas ali. Outra questão estudada no Plano dizia respeito à manutenção da diversidade social, procurando antecipar as mutações sociais, que ocorreriam quando da valorização do local, devido a isso era realizado um levantamento detalhado das classes sociais que habitavam o setor, tal qual das condições para sua manutenção após a implementação do PMSV (MCC, 2000).

A concepção do setor salvaguardado teve dentre seus objetivos o incentivo ao restauro e conservação de imóveis através de financiamento do Estado. O financiamento era viabilizado por meio de redução de $36 \%{ }^{70}$ no imposto de renda e

69 O PSMV continua sendo necessário quando da instituição de um Site Patrimonial Remarquable, contudo neste trabalho adotaremos o tempo passado quando nos referirmos a este posto que estamos tratando dos anos iniciais de instituição do Plano.

70 Porcentagem aprovada pelo código geral de impostos (no original: Code Géneral de Impôts). O teto estipulado para limitar a obtenção da isenção é aprovado anualmente pela lei de finanças (no original Loi de Finances - ato legislativo pelo qual o Parlamento francês avalia o orçamento do Estado para o 
poderia ser utilizado, tanto para despesas incorridas na restauração, manutenção e reparos, como também para a aquisição e execução de obras ${ }^{71}$, desde que o PSMV tivesse sido aprovado. Além disso, a Comuna era incentivada a realizar programas que pudessem complementar o Plan de Sauvergarde et de Mise en Valeur como, por exemplo, de habitação social, plano de transporte urbano, bem como as operações financeiras que permitiriam a implementação de seus objetivos: restauração dos edifícios, operações programadas de habitação ${ }^{72}$, redução de habitação insalubres, aumento da densidade nos setores entre outros (MCC, 2000).

A redução no imposto de renda tinha dentre seu objetivo inicial o aumento de densidade nos setores, posto que a isenção somente era concedida aos imóveis que tinham como destinação o uso habitacional ou para os imóveis destinados à habitação em sua origem, mas que, após a efetivação do Plano, fossem utilizados por profissionais liberais (advogados, arquitetos, médicos, dentistas e afins). Porém, após algumas modificações do Code d'Urbanisme ${ }^{73}$ e do Code de Patrimoine ${ }^{74}$ assim como, de adaptações da lei de finanças ${ }^{75}$ os proprietários de imóveis com interesse cultural, em geral, ${ }^{76}$ também passaram a usufruir deste incentivo. O diferencial no que se referia à concessão de isenção dentro do perímetro salvaguardado estava no fato de que esta também poderia ser utilizada para demolição do imóvel, reconstrução de telhados e/ou paredes externas, como também poderia ser obtida quando da mudança de uso num imóvel, neste caso, para habitação. Neste contexto, a

ano posterior) que corresponde, no Brasil, a Lei Orçamentária Anual. Disponível em: https://www.senat.fr/role/fiche/loi fin.html Acessado em: 21.08.2017

${ }^{71}$ Contudo este incentivo não é mais exclusivo aos proprietários de imóveis, como era em 1964, quando da regulamentação da lei, em setores salvaguardados. Este benefício se estende a todos imóveis classificados como monumentos históricos, aos que fazem parte do inventário suplementar dos monumentos históricos bem como aos imóveis pertencentes a Fundação do Patrimônio (no original: Fondation du Patrimoine), criados pela Lei n $96-590$, de 2 de julho 1996, que não são nem classificados muito menos inscritos (SENAT, 2002).

72 No original: Opérations Programmées d'Amélioration de l'Habitat (OPAH). Programa lançado em 1977, utilizado para conjuntos de habitação em comum que enfrentam graves dificuldades técnicas, sociais e financeiras (TOMASIN, 2002).

${ }^{73} \mathrm{Em}$ tradução livre: Código de Urbanismo, é o código que agrupa no direito francês as disposições legislativas e regulamentares relativas ao direito do planejamento urbano. Tradução da autora. Disponível em: www.legisfrance.fr. Acesso em: 28 mar.2017.

74 Opus cit.

75 No Brasil chamamos de decreto de execução orçamentária, este é responsável por fixar normas referentes à execução orçamentária e financeira para o exercício do ano seguinte.

${ }_{76}$ Cada caso obedece a diferentes regras para obtenção do incentivo, há desde a imposição de abertura do imóvel à visitação até a necessidade de alugar o bem após o restauro por um período determinado (FRANÇA, 2002). 
concessão poderia ser realizada desde que o setor dispusesse de um Plan de Sauvergarde et de Mise en Valeur.

Salvaguardados pela aura patrimonial e pelas vantagens fiscais e financeiras, os setores protegidos foram prejudicados pela escassez de orçamentos dos Ministérios que financiavam as operações e, em seguida, por seu único projeto. Poucos PSMVs foram capazes de implementar a ambição e abordagem complexa atribuídos a eles por seus desenvolvedores. Devido a mudança de uso incentivada pelo plano, os preços da terra baixaram, os moradores antigos se deslocaram (de 1962 a 1990 a demanda foi de 50\%) para novos bairros devido à grande incidência dos novos empreendimentos implantados, que não comportavam famílias visto que os incorporadores investiam na construção de estúdios. Os novos usos destinados aos setores, aliados aos novos modelos de moradia, foram responsáveis por atrair uma população mais jovem, que trouxe consigo novos cafés, bares e restaurantes diminuindo a diversidade populacional destas áreas e, por consequência, a tão sonhada densidade que fazia parte dos objetivos iniciais da concepção dos setores (ANVPAH \& VSSP, 2012).

A delimitação de um perímetro onde serão concedidos incentivos à preservação e valorização do patrimônio é uma questão a ser estudada e implantada com critérios pormenorizados. No caso do setor salvaguardado, a delimitação de uma área de preservação fez com que aumentasse, visualmente, a discrepância entre as características arquitetônicas e urbanas de seu entorno imediato, que não apresentava as características particulares do conjunto a ser preservado, mas que ainda mantinham certa leitura e conformidade com o perímetro salvaguardado. Por este motivo, a gestão destas "franjas" deveria ser tratada como uma continuidade, porém, não por um PSMV, mas com um procedimento complementar de proteção. Para tratar desta questão, e de questões correlatas, em 1983 o Estado francês instituiu a Zone de Protection du Patrimoine Architectural, Urbain et Paysager (ZPPAUP) ${ }^{77}$ (METL, 2000).

77 Em tradução livre: Zona de Proteção do Patrimônio Arquitetônico, Urbanístico e Paisagístico (ZPPAUP). É um dispositivo estabelecido pela Lei de 7 de janeiro de 1983, cujo campo foi estendido pela Lei de "paisagens" de 8 de janeiro de 1993. Esta destina-se a definir, um acordo entre o Estado e as comunidades, dos métodos de gestão de um setor urbano de interesse patrimonial (FRANÇA, 1983). 
2.1.2 A ZPPAUP - incentivando a preservação nas áreas envoltórias francesas

As Zones de Protection du Patrimoine Architectural, Urbain et Paysager (ZPPAUP), instituídas através da Lei no n $^{03-8}$ de 7 de janeiro de $1983^{78}$ e, complementadas pelo artigo $6^{\circ}$, da Lei №93-24 de 8 de janeiro de 1993, foram elaboradas para estabelecer a regulamentação da área envoltória dos monumentos históricos e dos locais a proteger ou a destacar por motivos de ordem estética, histórica ou paisagística. A ZPPAUP se configurava como uma servidão de utilidade pública, significando com isso que limitações administrativas são impostas ao proprietário de imóvel contido neste perímetro com objetivo de proteger e conservar o patrimônio natural e cultural ali contido, anexada ao Plan Local d'Urbanisme (PLU).

Por ter um caráter diverso, abrangendo desde áreas envoltórias em bairros de grandes cidades à conjuntos urbanos rurais e, aliando a isso a delegação, em matéria de competência governamental às Comunas para realização do Plan d'Urbanisme e ainda, por manter no nível federal a responsabilidade pelo patrimônio cultural, A ZPPAUP, a princípio, não dispunha de uma metodologia para sua efetivação. Contudo, alguns anos após os primeiros estudos efetivados, estes foram avaliados e os melhores serviram de referência para elaboração de um método para criação das zonas (ACTES DU SEMINAIRE DE CHINON, 2006).

A iniciativa para elaboração da ZPPAUP era realizada pelo prefeito $^{79}$ da Comuna com consentimento do Conselho Comunal. Após aprovação do Conselho, o ato pelo qual o estudo era prescrito deveria ficar exposto na prefeitura, bem como ser publicado em dois jornais oficiais da região, para conhecimento público, no entanto, a população não era consultada nesta fase. Após um mês de disponibilização do ato, iniciava-se a elaboração do projeto para a ZPPAUP, sob a autoridade do prefeito da

\footnotetext{
78 "Art 70 - Por proposição ou após acordo do conselho municipal dos municípios em questão, as áreas de proteção para o patrimônio arquitetônico, urbano e paisagístico poderiam ser instituídas envolta de monumentos históricos e em bairros, locais e espaços a serem protegidos ou desenvolvidos por razões de ordem estética, histórica ou cultural" (Id.,1979).

79 A iniciativa de criar uma ZPPAUP poderia ser realizada tanto pelo prefeito da Comuna, ou das Comunas envolvidas, quanto pelo prefeito da região. Visto que a zona poderia abarcar parcelas de solo que avançassem por várias Comunas (FRANÇA, 1983).
} 
Comuna e com a assistência do Architect des Bâtiments de France ${ }^{80}$ (ABF) (FRANÇA, 1984).

O estudo do projeto era realizado pela Comuna, responsável por fixar o período de duração do trabalho, em conjunto com o Estado, contando também com a colaboração da Direction Régionale des Affaires Culturelles (DRAC) ${ }^{81}$, a Direction Départamentale de l'Equipement (DDE), a Direction Régionale de l'Environnement (DRE), da Comissão regional de patrimônios e locais de interesse, historiadores, geógrafos, juristas e dos habitantes, reunidos em associação ou não. Nesta fase o objetivo se concentrava em recolher a maior quantidade de informações disponíveis sobre a zona a ser implementada, para assim iniciar o projeto efetivo ${ }^{82}$. Cumpre destacar que o financiamento do custo global do estudo deveria ser dividido entre o Estado e a Comuna (FRANÇA, 1984).

Após a finalização do projeto este era submetido a avaliação do Conselho Comunal, que deveria se pronunciar por um período de até quatro meses, caso contrário, a decisão era acatada como positiva. O projeto era então colocado para apreciação pública, através da realização de uma enquete, e posteriormente era solicitado aval do prefeito regional, que buscaria a apreciação do Conselho regional de patrimônio e locais de interesse, para então, estabelecer a ZPPAUP (BOUZELY, 1986).

A implantação de uma Zone de Protection du Patrimoine Architectural, Urbain et Paysager permitia simplificar a gestão do patrimônio pois, contrariamente aos setores salvaguardados, a zona abarcava uma grande diversidade de espaços e poderia ser instituída tanto em bairros centrais, quanto zonas pericentrais e, até mesmo, em zonas rurais. Um dos principais fatores do sucesso da ZPPAUP se fundamentou na suspensão das áreas envoltórias ${ }^{83}$, locais em que o ABF tinha um grande poder de decisão pois a análise de projetos e intervenções nestas áreas eram

\footnotetext{
${ }^{80}$ Arquiteto de edificações da França. Tradução da autora. Profissional responsável, designado pelo Estado, pelo patrimônio construído do país.

81 Direção regional dos negócios culturais. Tradução da autora.

82 O documento é composto por um relatório de apresentação onde deverão ser expostos os motivos para criação da zona bem como o estado inicial da proteção e as características do patrimônio que virão a compor a ZPPAUP, peças gráficas, prescrições e recomendações onde serão ditadas as regras e diretrizes a serem seguidas tanto pelo Architect des Bâtiments de France (ABF) quanto pelos moradores, para evitar paralisias ao longo da efetivação do projeto (BOUZELY, 1986).

${ }^{83}$ A ZPPAUP suspende a(s) área(s) envoltória(s) mas não substitui, pois caso a zona seja extinta, a lei de 1913 relativa as áreas envoltórias de monumentos históricos passarão a valer novamente (Id., 1986).
} 
realizados subjetivamente, já que não contavam com regulamentação específica (GIGOT, 2008).

Outro fator de sucesso da ZPPAUP se concentrou na disponibilidade de incentivos viabilizados para a preservação do patrimônio construído. Estes estavam centralizados em três grupos: subvenções públicas, subvenções concedidas pela Agência Nacional, no contexto de programas, e isenção fiscal. As subvenções públicas surgiam em forma de créditos, disponibilizados pela DRAC e pelas coletividades locais: região, comuna e departamento, para favorecer a restauração de imóveis; já as subvenções concedidas no contexto de programas como as Opérations Programmées d'Amélioration de l'Habitat (OPAH) ou da Agence Nationale pour l'Amélioration de l'Habitat (ANAH), eram disponibilizadas para senhorios e proprietários de baixa renda e para trabalhos isolados. O Estado poderia, ainda, conceder subsídios aos proprietários de baixa renda para ajudá-los com os custos adicionais referentes aos serviços especializados nas obras de reabilitação e de aquisição de imóveis nas zonas de proteção (FRANÇA, 2002).

A isenção fiscal poderia ser obtida a partir da Lei Malraux, a mesma que regia o incentivo fiscal nos setores salvaguardados, e permitia a dedução de $27 \%$ de imposto nos trabalhos realizados no ano, desde que esta não ultrapassasse o limite do montante anual estipulado pelo Estado ${ }^{84}$. Este regime só poderia ser adquirido pelos proprietários que comprovassem situação de baixa renda e, que se comprometessem a alugar o imóvel para uso habitacional, exclusivamente, por um período de nove anos após a conclusão da obra (ACTES DU SEMINAIRE DE CHINON, 2006).

Os regimes fiscais constantes tanto do setor salvaguardado quanto da ZPPAUP eram extremamente generosos em concessão de incentivos. Contudo concluímos que, um proprietário de imóvel no perímetro da ZPPAUP, apesar de ter uma taxa menor de isenção em relação a proporcionada num setor salvaguardado, detinha privilégio na obtenção deste incentivo. Exemplificaremos utilizando a hipótese de um trabalho de restauro para um imóvel destinado a função habitacional: no âmbito da

\footnotetext{
${ }^{84}$ Porcentagem aprovada pelo código geral de impostos (no original: Code Géneral de Impôts). O teto estipulado para limitar a obtenção da isenção é aprovado anualmente pela lei de finanças (no original: Loi de Finances - ato legislativo pelo qual o Parlamento francês avalia o orçamento do Estado para o ano posterior. Tradução da autora.) que corresponde, no Brasil, a lei orçamentária anual.
} 
ZPPAUP este imóvel tinha como obrigação o restauro da fachada, podendo alterar livremente o interior da construção; no caso do imóvel se encontrar no perímetro do setor salvaguardado este deveria restaurar o edifício em sua plenitude sem quaisquer alterações, somente seria permitida adaptação para conformidade com a lei de acessibilidade.

Em ambos os casos acima descritos, a isenção de imposto recairia sobre a totalidade da obra, porém o proprietário de imóvel num setor salvaguardado deveria contratar mão de obra especializada para restaurar o edifício completo, logo, considerando que o custo deste tipo de trabalho seria maior em relação a um trabalho de reforma comum, esta obra teria um preço mais elevado em relação a obra realizada num edifício que se encontrasse numa ZPPAUP. Outra questão a ser avaliada se fundamenta nas alterações realizadas no interior do edifício que, eram permitidas numa ZPPAUP, mas não neste caso, no setor salvaguardado.

Segundo o dispositivo constante da Lei Malraux, os proprietários eram obrigados a alugar o edifício por um período de nove anos após o término das obras. Sendo assim, o possuidor de um imóvel no setor salvaguardado ficava impossibilitado de externar o custo despendido na obra de restauro, através da locação do imóvel para um número maior de moradores do que aquele que originalmente poderia ocupar o prédio já que a construção não poderia ser alterada internamente. Porém, o imóvel pertencente a uma ZPPAUP dispunha de liberdade para possíveis alterações já que sua obrigação se concentrava em manter a fachada de acordo com o restante da paisagem que compunha a zona.

Apesar do imóvel constante do perímetro de uma ZPPAUP usufruir de uma taxa de isenção menor, o custo de sua obra de restauro também era menor, considerando que o trabalho de mão de obra especializada ficaria concentrado somente na fachada, entretanto, a isenção recairia sobre o custo total da obra. Logo, este, possibilitado de alterar externamente o imóvel, poderia se beneficiar com a cobrança de aluguel de um maior número de locatários, visto que tinha a possibilidade de adequar o imóvel para a maior quantidade de moradores possíveis dentro do permitido pelos códigos de edificações e urbanismo. Esta possibilidade de lucrar com aluguel, ou mesmo com a isenção do imposto, atraiu um número considerável de grandes investidores e fez 
com a Lei Malraux no perímetro da ZPPAUP favorecesse os grandes proprietários (BERGEL, 2010).

Outra desvantagem em disponibilizar o mesmo incentivo para dois perímetros com regulamentações distintas se baseava na questão da necessidade de aprovação de um PSMV nos setores salvaguardados, para que o proprietário pudesse obter a isenção. Caso contrário, antes da aprovação do PSMV, o imóvel deveria ser declarado como de utilidade pública. Considerando que a aprovação do plano poderia demorar até dezenove anos para ser concluído como em casos exemplificados na literatura, e, no caso da ZPPAUP o proprietário poderia solicitar a isenção durante a aprovação da zona pois, ao final da aprovação, o imóvel teria como regime jurídico a servidão pública e, a aprovação da zona demoraria, no máximo, quatro anos que é o mesmo período ao qual o proprietário, em ambos os casos, poderia usufruir do incentivo.

Entendemos a diferença, assim como a necessidade, de demarcação de um setor salvaguardado tanto quanto de uma ZPPAUP. Porém, pensamos que, se a ZPPAUP foi criada tendo como um de seus objetivos regulamentar as áreas envoltórias dos setores salvaguardados, a isenção de imposto deveria ser utilizada de um modo mais restritivo. Pois a grande vantagem que a isenção aplicada a uma ZPPAUP demonstrava em relação a um setor salvaguardado fez com que o segundo se tornasse menos interessante para investimentos. Sendo assim, o incentivo não contribuiu, ou desvirtuou, o princípio inicial de criação da Lei Malraux e, por consequência, a dos setores salvaguardados, que era a preservação e valorização deste num contexto urbano colocando-o, através do PSMV, como um projeto urbano responsável por incentivar a preservação do patrimônio construído.

Em 2010, foi aprovada uma nova lei conhecida por Loi Grenelle II, esta foi responsável por estabelecer um novo instrumento de proteção para o patrimônio arquitetônico, urbano e paisagístico, que substituiu a Zone de Protection du Patrimoine Architectural, Urbain et Paysager (ZPPAUP), intitulado Aires de Valorisation de l'Architecture et du Patrimoine (AVAP). Poucas foram as alterações realizadas, e dentre estas estava a melhor articulação entre o instrumento e o Plan Local d'Urbanisme (PLU), cujo ato de aprovação da AVAP implicaria em revisão ou modificação do plano, como acontecia com os setores salvaguardados. No que se 
refere ao financiamento do restauro do patrimônio, não foram realizadas alterações (PLANCHET, 2011).

A aplicação desta nova lei tinha um período de cinco anos para substituir a ZPPAUP mas em 2016 foi aprovada a concepção de um novo dispositivo. A lei de 07 de julho de 2016, responsável por criar os Sites Patrimoniaux Remarquables substituiu os antigos dispositivos de proteção: Secteur Sauvegardé, Zone de Protection du Patrimoine Architectural, Urbain et Paysager (ZPPAUP) e Aires de Valorisation de l'Architecture et du Patrimoine (AVAP). Apesar desta supressão o novo instrumento manteve o Plan de Sauvegarde et Mise em Valeur, como documento de urbanismo, e - Plan de Valorisation de l'Architecture e du Patrimoine, como servidão de utilidade pública, que pertenciam ao setor e zonas suprimidas. (FRANÇA, 2016)

Não iremos discorrer sobre este novo instrumento visto que o objetivo desta dissertação em analisar os Setores Salvaguardados, a ZPPAUP e a ZAC, ainda por ser estudada neste capítulo, vai de encontro à necessidade de demonstrar quais eram os incentivos concedidos pelo governo francês ao patrimônio cultural edificado, e, qual sua relação com os projetos e planos formulados em São Paulo, a partir de 1970, bem como ao incentivo, que é o tema principal deste estudo, concedido aos proprietários de imóveis tombados na área central de São Paulo.

\subsubsection{Os bens de interesse cultural no contexto da Zone d'Amenagement Concerté}

A Zone d'Aménagement Concerté (ZAC) foi instituída pela Lei no67-125385 e teve como precursora a Zone à Urbanizer en Priorité (ZUP), de 1953. Este instrumento urbanístico é, atualmente, na França, uma das principais ferramentas utilizadas para promover a requalificação e as intervenções urbanas. Estabelecida há 50 anos, a ZAC foi objeto de constantes aperfeiçoamentos ao longo deste período, contudo manteve sua característica principal, que é combinar o planejamento do uso do solo com um programa de desenvolvimento de infraestrutura (MALERONKA, 2010).

${ }^{85}$ Loi n 67-1253 du 30 décembre 1967 d'orientation foncière (FRANÇA, 1967). 
Neste texto, iremos centrar a análise do funcionamento da ZAC em seus anos anteriores a aprovação da lei sobre Solidariedade e Renovação Urbana (SRU) ${ }^{86}$ no ano 2000 , pois neste período que a mesma se constituiu como objeto de estudo por parte da Empresa Municipal de Urbanização de São Paulo EMURB e da Coordenadoria Geral de Planejamento em São Paulo nos anos 70, para embasamento das Operações Interligadas (EMURB, 1977).

\begin{abstract}
"As Zone d'Aménagement Concerté (ZAC) são as zonas onde uma coletividade pública ou um estabelecimento público decidem intervir para realizar, ou fazer realizar o planejamento e equipamento dos terrenos, especialmente daqueles que esta coletividade ou este estabelecimento adquiriu ou irá adquirir em vias de ceder ou conceder posteriormente a usuários públicos ou privados ${ }^{87 "}$ (FRANÇA, 1967. Art. 16º).
\end{abstract}

As ZAC se constituem como uma operação de desenvolvimento e, segundo o Code de l'Urbanisme em seu artigo L.300-1, as ações de desenvolvimento destinamse a implementar um projeto urbano, uma política local de habitação, a salvaguardar ou valorizar o patrimônio construído 88 ou não construído, entre outros. Estas se efetivam através da delimitação de um perímetro onde são estabelecidos os objetivos e as diretrizes da intervenção, para então ser efetuado um Plan d'Aménagement de zone (PAZ) ${ }^{89}$. O PAZ era responsável por definir, também, os parâmetros construtivos a serem estabelecidos no interior da zona e se colocava como uma fase intensa de estudo e procedimentos, para então ser alvo de uma consulta pública (BRASIL, 2016).

A iniciativa de instituir uma Zone d'Amenagément Concerté é de responsabilidade do Estado, de uma autoridade local ou de uma instituição pública. $O$ poder público representado pelos órgãos competentes em matéria de urbanismo é o responsável pela delimitação do perímetro da zona, que pode ser realizada sem consulta anterior a $\mathrm{L}^{\prime} \mathrm{ABF}^{90}$, mesmo que um dos terrenos inclusos no perímetro se encontre no campo de visibilidade de um monumento inscrito no inventário suplementar dos monumentos históricos (IBANEZ, 1998). Este é, também, o

\footnotetext{
86 Loi no 2000-1208 du 13 décembre 2000 relative à la solidarité et au renouvellement urbains (SRU) (FRANÇA, 2000).

87 Tradução da autora.

88 Grifo da autora.

${ }^{89}$ Após a aprovação da Loi SRU não existe mais a necessidade de elaborar um PAZ.

90 Característica que não foi alterada com a aprovação da lei SRU, no ano 2000.
} 
responsável por gerenciar a operação assim como o encarregado de sua concretização.

\begin{abstract}
"A partir do ato que cria a zona, os proprietários de terrenos inclusos nesta podem notificar a autoridade competente que a instituiu, para proceder a aquisição de suas terras, informando qual o uso do imóvel e se este tem inquilino ou não. Então, por meio de publicação coletiva e notificação formal todas as partes interessadas são informadas e devem se dar a conhecer no prazo de dois meses ${ }^{91}$ " (FRANÇA, 2017, online).
\end{abstract}

Segundo o Code de l'Urbanisme, a iniciativa de instituir a ZAC pertence, e isso não foi alterado com a promulgação da Lei SRU em 2000, ao Estado, contudo, a sua realização pode ser assegurada pelo poder público a uma entidade privada, através de um contrato após a escolha da mesma por procedimento licitatório (Art. L.300-4). Porém na literatura existente, e mesmo uma das ZAC mais famosas, - a Paris Rive Gauche, que tem como gerenciadora a SEMAPA ${ }^{92}$ (Société d'Étude, de Maitrise d'Ouvrage et d'Aménagement Parisienne), demonstra que esta organização é, geralmente, uma sociedade de economia mista, cuja responsabilidade também se concentra em promover os investimentos necessários em infraestrutura e revender os terrenos à iniciativa privada (MALERONKA, 2010).

Optamos por sublinhar este caráter da instituição de uma sociedade de economia mista como parceira do Estado na efetivação da ZAC pois no regime jurídico francês as sociedades de economia mista não estão sujeitas à lei de licitação e devido a este adendo pensamos que, ou o disposto no código de urbanismo daquele país não se efetivou, apesar de se manter na lei até os dias atuais, ou nos falta uma análise mais detalhada das leis e dos procedimentos para esta fase de implantação de uma Zone d'Amenagément Concerté. Porém, em virtude deste não ser o enfoque principal do presente estudo, iremos prosseguir com a prerrogativa da ZAC que tem em sua composição uma sociedade de economia mista, sem focarmos em como é realizada a etapa de composição e aceitação pelo poder público desta.

Destaca-se, portanto, uma importante característica da ZAC, a permissão de parcerias entre o poder público e a iniciativa privada. Cabendo à iniciativa privada o

\footnotetext{
91 Tradução da autora.

92 A SEMAPA foi instituída como sociedade de economia mista em 1985, porém só foi definida operadora da ZAC em 1991. Disponível em www.semapa.fr Acessado em 17/08/2017.
} 
direito de expropriar e comprar qualquer imóvel constante do perímetro. Sua responsabilidade também se concentra na construção dos edifícios e espaços públicos, assim como a venda e repasse dos equipamentos para os usuários e futuros proprietários. Ainda dentre suas responsabilidades, esta organização deveria seguir o PAZ, nos casos de ZAC, instituídas antes do ano 2000, e se encarregar de todas as audiências necessárias durante o processo de produção da zona (BRASIL, 2016).

A primeira audiência ocorria ${ }^{93}$ quando o Estado, já com o perímetro da ZAC definido, assim como as diretrizes e os objetivos traçados, mostrava à população $O$ estudo do projeto. Era nesta fase que a população se manifestava, na maioria dos casos, agrupada em associações, acerca do projeto e das tomadas de decisão, por exemplo, no que se refere ao patrimônio construído existente no perímetro. Utilizaremos como exemplo dois casos: a ZAC Paris Rive-Gauche e a ZAC Belleville (não concretizada) para demonstrar como foi realizada a incorporação do patrimônio cultural num projeto de Zone d'Aménagement Concerté.

O projeto inicial para a ZAC Paris Rive-Gauche foi contestado logo em sua primeira audiência. Entre as alegações das associações representantes da população estava a falta de vínculo do projeto com as pré-existências dos bairros. Este propunha a cobertura total das vias férreas em virtude da construção de uma nova grande avenida sobre os trilhos, desconsiderando a memória ferroviária que marcava aquela área da cidade e, também previa a demolição de patrimônio industrial e ferroviário (NEZ, 2012).

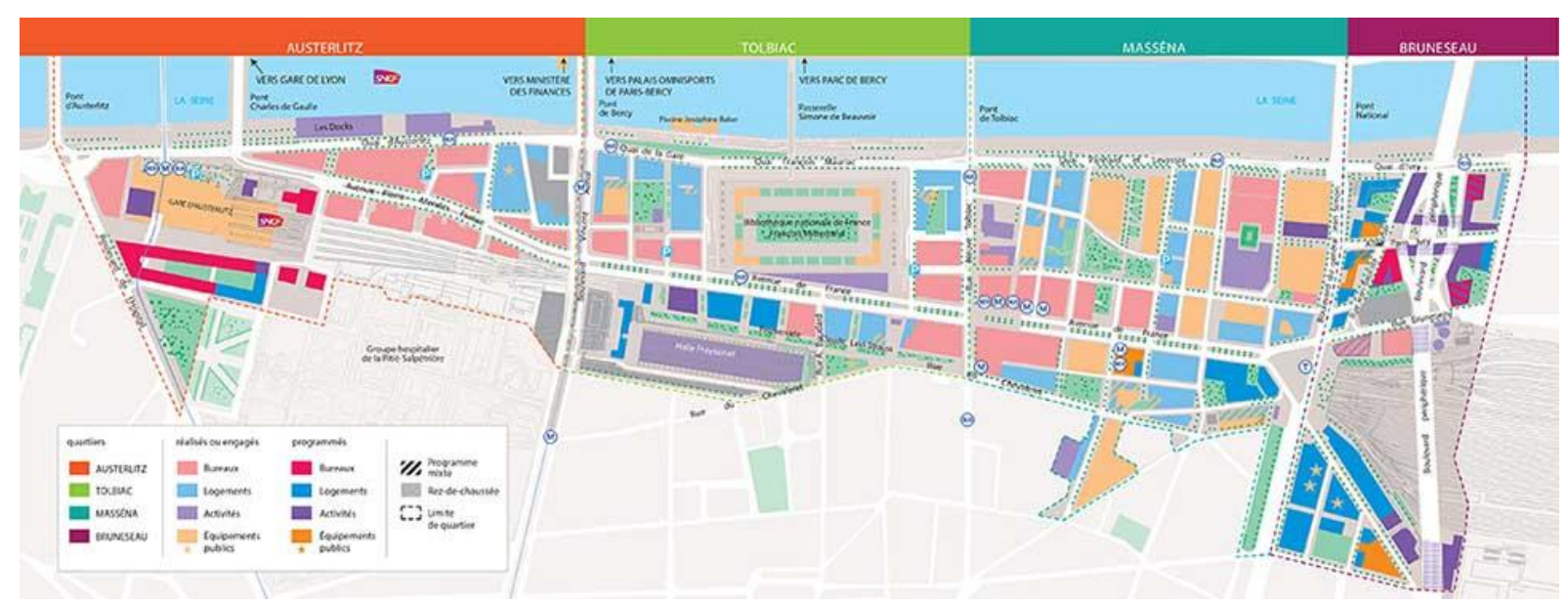

Figura 2.1 - Plano ZAC_Paris Rive Gauche. FONTE: SEMAPA, 2012.

93 Visto que atualmente não é mais necessária a elaboração de um PAZ. 
Foi estabelecida a criação de uma Comissão de Audiências permanente durante todo o processo da operação, respondendo ao solicitado pelas associações de moradores e, com isso, o projeto foi alterado passando a privilegiar a preservação de algumas instalações históricas como o Grand Moulins de Paris e o edifício Frigos (antigos armazéns frigoríficos ocupados desde 1980 por artistas e artesãos), anteriormente marcados para demolição, assim como o Halle Sernam e ainda, parte da via férrea, que teve parte de sua estrutura mantida ao ar livre como forma de memorial à história do local (NEZ, 2012).

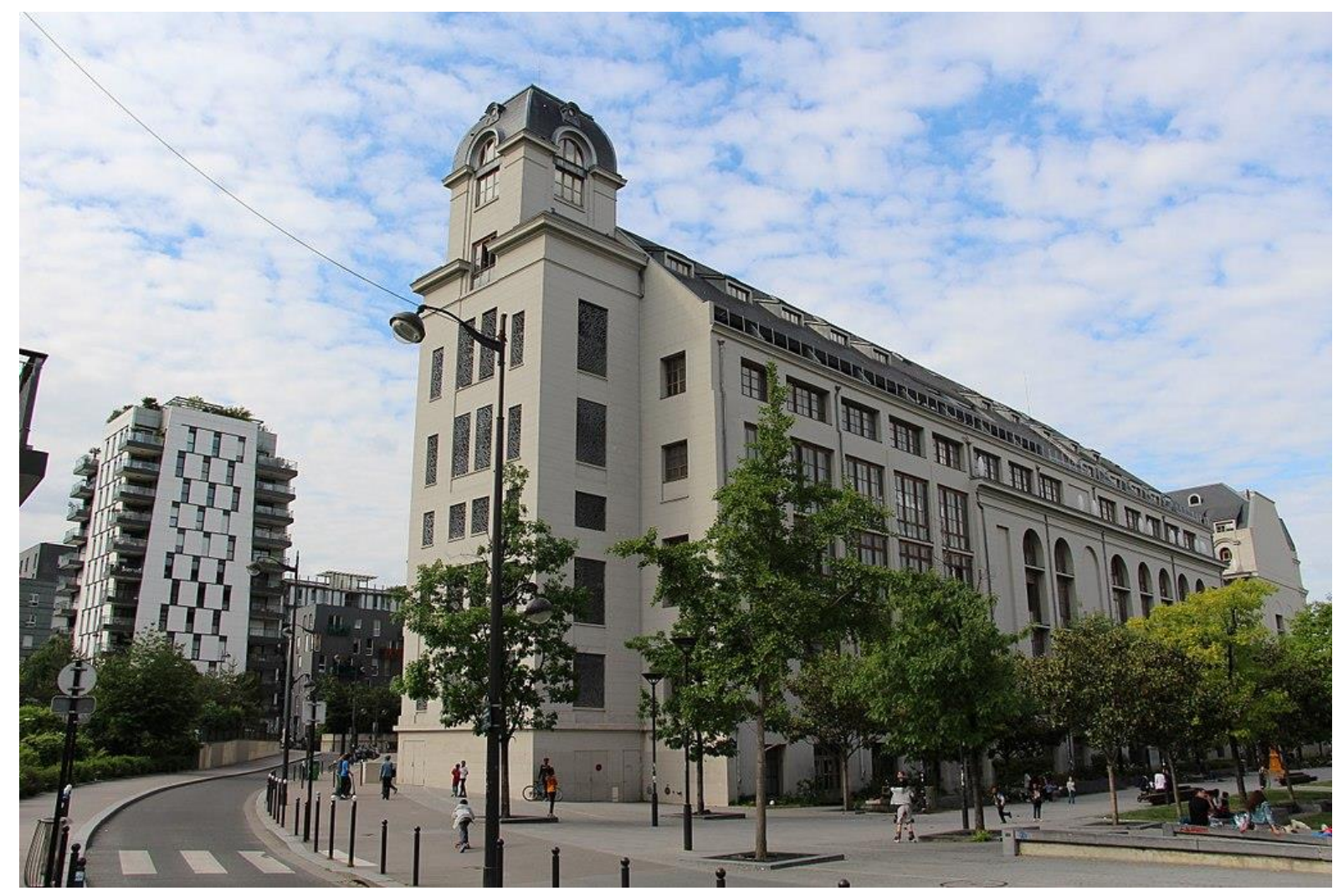

Figura 2.2 - Les Grands Moulins, Paris Rive Gauche. Fonte: Wikimedia Commons, 2016.

Já a ZAC Belleville, foi projetada para uma área classificada pela municipalidade de Paris como zona insalubre, e, em 1990, foi proposto um plano de reconstrução sob a forma de uma Zone d'Aménagement Concerté. $\mathrm{O}$ bairro é composto por um caráter singular, guardando ainda características dos antigos faubourgs parisienses, onde os edifícios se localizam em lotes longos e estreitos e os imóveis são alternadamente separados por oficinas de artesãos e artistas (SENLY, 1999). 
Agrupados em associações de moradores e artistas, os habitantes do bairro lutaram durante cinco anos com a municipalidade de Paris para que esta abandonasse o projeto de ZAC para o local, visto que este tinha como premissa realocar os moradores do bairro enquanto fossem realizadas as obras, contudo não garantia o realojamento total da população quando da finalização do projeto. Outra questão apresentada, que era contrária ao desejo da população, se referia a destruição de edifícios históricos que eram ocupados por grupos de artistas, já há alguns anos. Em 1996, após seis anos de lutas, a municipalidade decidiu interromper o projeto de ZAC em favor de uma Operátion d'Amelioration de l'Habitat (OPAH) se comprometendo, também, a renovar os edifícios ocupados por artistas (GRAVEREAU, 2012).

Os casos acima exemplificados demonstram a importância das audiências para um projeto urbano que tem, em seu perímetro, imóveis de valor cultural. A participação da população nestes dois casos foi fundamental para a preservação do patrimônio e sua inserção num projeto de renovação que não tinha as pré-existências como premissa projetual.

$\mathrm{Na}$ literatura pesquisada não encontramos referências a financiamento, no contexto de uma ZAC, para restauro do patrimônio construído. Contudo, ainda utilizando um exemplo dado acima, Les Grands Moulins - inscrito em 2001 na lista de monumentos históricos da França, verificamos que é possível obter subvenção dos trabalhos de conservação pela Diréction Regional des Affaires Culturelles (DRAC), seja o edifício pertencente a proprietário público ou privado. A taxa máxima de isenção é de $40 \%$ para os monumentos inscritos, e este incentivo pode ser cumulativo com outros incentivos concedidos pelas autoridades locais, neste caso cada localidade define os termos da ajuda (MCC, 2000).

Ressaltamos que nenhuma disposição impedia a inclusão de uma ZAC dentro de um perímetro de setor salvaguardado ou uma ZPPAUP, contudo as regras destes setores poderiam ir contra este procedimento. O PSMV substitui o Plan Local d'Urbanisme (PLU) e por isso deve ser considerado quando da proposta de criação de uma Zone d'Aménagement Concerté no perímetro de um Secteur Sauvegardé pois a ZAC é subordinada ao PLU (art. 311-6 do Code de l'Urbanisme), logo, deveria se subordinar ao PSMV. Já no que diz respeito à implementação de uma ZAC no perímetro de uma Zone de Protection du Patrimoine Architectural, Urbain et Paysager 
a operação de desenvolvimento que se constitui através de uma ZAC pode não ser não aprovada por ser incompatível com os objetivos e requisitos da ZPPAUP (SCET, 2013).

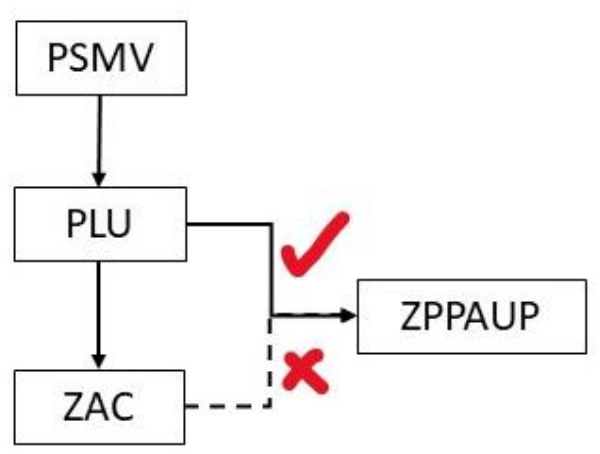

Figura 2.3 - Níveis de competência dos planos. Tabulação da autora sobre texto. Fonte: SCET, 2013.

No que concerne ao financiamento da Zone d'Aménagement Concerté são considerados vários elementos para administrar o risco que a operação carrega. Primeiramente deve-se comprovar que a operação tem condições de valorizar os terrenos e o direito de construir, a valorização (mais-valia) deve ser suficiente para financiar as obras e isto deve ser comprovado pelo governo local por meio da organização gerenciadora da operação (sociedade de economia mista) pois, caso contrário, aquele deverá arcar com o ônus (ADAM, 2008).

Os financiamentos são efetuados por escalonamento, porém o Code de l'Urbanisme francês não define o conteúdo nem em quais termos a ação deve ser realizada. Apesar disso, o financiamento projetado da operação deverá compor um relatório onde também estarão descritos o programa físico e o cronograma de conclusão estimado. Este relatório servirá de base para se obter uma estimativa do custo total da operação e o valor a ser financiado.

A Lei $n^{\circ} 67-1253$ de $1967^{94}$ estabeleceu assim os princípios básicos do sistema dentro de uma operação de desenvolvimento:

94 A lei de 30 de dezembro de 1967 fixou o objetivo de tributar participações financeiras: estas não podiam exigir nada fora do contexto das chamadas tarifas de planejamento urbano, cujos termos e condições foram estabelecidos por lei (JEGOUZO, 2009). 
- a regra seria o financiamento da operação através de um imposto ${ }^{95}$ pago pelos construtores. O financiamento por um imposto específico é indiscutivelmente 0 sistema que oferece mais garantia ao construtor. O princípio da legalidade do imposto protege contra a arbitrariedade da administração e assegura a transparência dos custos da operação posto que a taxa é conhecida pelo construtor anteriormente a qualquer decisão tomada.

- a exceção seria o uso de participações financeiras pelos construtores ou gestores da operação, negociadas ou não (JEGOUZO, 2009).

Além de instituir a ZAC, a Loi d'Orientation Foncière de 1967 foi responsável por estabelecer as disposições relativas ao desenvolvimento e implementação dos Plans d'Occupation des Sols ${ }^{96}$ (POS), que, ao mesmo tempo, institucionalizou o Coefficient d'Occupation des Sols (COS), isto é, a regulação das densidades, mas também o controle do direito de construção, relativo ao direito de propriedade. O COS exprimia a quantidade de metros quadrados de superfície plana passiveis de serem construídos por metros quadrados de superfície do solo (DUBOIS-MAURY,1983).

A lei, prevendo minimizar os efeitos da regra, onde alguns proprietários seriam mais beneficiados que outros, criou a possibilidade de ultrapassar a densidade além da permitida pelo COS. A ultrapassagem (dépassement - no original) somente seria concedida em três casos: razões de arquitetura e urbanismo, para incentivar equipamentos públicos e para a proteção de certas áreas naturais ${ }^{97}$. E estabeleceu ainda que, toda autorização de ultrapassagem de densidade deveria ter uma contrapartida, ou seja, a obrigação de pagar uma contribuição financeira a coletividade (DUBOIS-MAURY,1983).

A isenção da contrapartida somente seria possível nos casos onde fosse justificada por questões urbanísticas ou de arquitetura, assim como entre terrenos vizinhos, ou seja, um proprietário que desejasse construir acima do limite permitido

\footnotetext{
${ }^{95}$ No original: Taxe locale d'équipement (TA). A taxa local de equipamento instituída em 1967 se constitui como uma imposição inclusiva e geral estabelecida para as operações de construção. É utilizada para financiar as despesas gerais de urbanização do município. Disponível em: http://www.cohesion-territoires.gouv.fr. Acesso em: 19 ago. 2017

${ }^{96} \mathrm{Em}$ tradução livre: Plano de ocupação do solo. Este documento estabeleceu regras gerais e servidões de uso do solo, no âmbito das diretrizes dos planos diretores com os quais deveria ser compatível. Foi substituído em no ano 2000 - Loi SRU (Solidarité Renouvellement Urbain) pelo Plan Local d'Urbanisme (PLU).

${ }^{97}$ Art.21ํㅡ, Loi no $67-1253 / 1967$ (FRANÇA, 1967).
} 
estaria isento de pagar a contrapartida caso seu vizinho, do lote ao lado, se dispusesse a vender-Ihe seu potencial construtivo (FRANÇA, 1967). Apesar de a lei prever uma contrapartida, entendemos que esta nunca foi realizada, pois 0 art. 21 ao delinear que: por razões urbanísticas e arquitetônicas, sem dizer quais seriam estas razões, a ultrapassagem do solo não necessitaria pagar uma contrapartida, deixou o campo aberto para entendimentos diversos ${ }^{98}$.

A transferência do coeficiente do solo só poderia ser realizada para áreas que não ultrapassassem $20 \%$ do coeficiente do território, nas municipalidades que detivessem um POS e, ainda, para áreas restritas designadas pela lei. Concluindo, a transferência não poderia ser aplicada em Zone d'Aménagement Concerté visto que só era possível transferir em uma área que cobria entre um terço e um quarto da área total do Plan d'Occupation du Sol. Não encontramos em nossa pesquisa referências de aplicação da lei, entendemos que ao verificarem a ineficácia do instrumento este foi revisado e implementado quando da instituição de uma nova política fundiária francesa (FRANÇA, 1967).

A pesquisa do instrumento Zone d'Aménagement Concerté (ZAC) e da transferência do coeficiente do solo se fez premente considerando o embasamento histórico e técnico que necessitaremos para realizar a análise do objeto de estudo deste trabalho, que se concentra no instrumento da Transferência de Potencial Construtivo disponibilizado na Operação Urbana Centro, instrumento este que, segundo texto do Estatuto da Cidade, foi inspirado na ZAC francesa (CYMBALISTA, 2001).

\subsection{O Plafond Légal de Densité e a intervenção do Estado na propriedade}

Com a iniciativa de regular a densidade do uso do solo francês o Estado instituiu o Coeficiente de Aproveitamento do Solo e, para minimizar os efeitos da nova regra criou-se a possibilidade de ultrapassar a densidade além do permitido, e, com isso,

\footnotetext{
98 Tradução da autora.
} 
gradualmente, a distinção entre o direito de construir e o direito de propriedade começou a ser efetuada (FRANÇA, 1967).

Em 1975, foi formulada na França uma nova política fundiária e de reforma urbana, esta visava reduzir as desigualdades sociais decorrentes do zoneamento através de um melhor e maior controle sobre o uso e ocupação do solo, pois constatou-se que o zoneamento vigente contribuía para a desigualdade social corrente. Contava, ainda, em aumentar a participação da coletividade no processo de planejamento, num novo sistema de compartilhamento de responsabilidades entre Estado e Comunas (FURTADO et al., 2011).

A reforma surgiu com objetivo de fornecer uma solução para o problema da distribuição desigual do direito de construir de acordo com as zonas definidas pelos planos urbanos. A proposta foi embasada no relatório realizado pelo professor Jean Paul Gilli a pedido do Ministére de L'Equipement ${ }^{99}$, segundo o qual a permissão de construir além do direito auferido à propriedade deveria estar subordinada ao pagamento de um imposto a ser calculado sobre o excesso de coeficiente de solo que o proprietário desejasse obter, já que a lei de 1967, apesar de instituir a contrapartida também instituiu a isenção, sem delimitar efetivamente quais casos eram passíveis de serem isentos. O relatório de 1975 propunha que o produto obtido, com o pagamento do imposto sobre a ultrapassagem do coeficiente de aproveitamento do solo, deveria alimentar um fundo destinado a compensar os proprietários de terras que não pudessem construir acima da densidade permitida pela lei ${ }^{100}$ (GILLI, 1975).

Neste contexto, o Governo Francês estabeleceu a Lei ํํ 75 - 1328 de 31 de dezembro de 1975, que limitava o direito de construção a uma vez a área do terreno, definindo um Plafond Légal de Densité (PLD) ${ }^{101}$, com exceção de Paris onde o limite ficaria restrito a 1,5. O direito acima deste limite, nos casos em que a legislação permitia, passaria à coletividade. Para que o proprietário pudesse exceder o limite, o

\footnotetext{
${ }^{99}$ Ministério do Equipamento. Tradução da autora.

100 A proposta do fundo de compensação aos proprietários não foi formalizada pela lei (FRANÇA, 1975). 101 Teto legal de densidade. Tradução da autora. O PLD foi revogado pela Lei de Solidariedade e Renovação Urbana (SRU) de 13 de dezembro de 2000, ficava facultado a cada município, antes desta data, solicitar sua manutenção caso contrário este seria revogado. Sendo assim não podemos afirmar que o instrumento está extinto, contudo utilizaremos o tempo passado para descrevê-lo visto que encontramos referência de sua utilização nos dias atuais.
} 
mesmo deveria pagar à Prefeitura uma soma ${ }^{102}$ equivalente ao valor correspondente ao metro quadrado do terreno, na proporção da área em excesso, obtendo assim a licença de construção. O pagamento poderia ser parcelado em três vezes, sendo que a primeira parcela deveria ser realizada ao final do terceiro mês após obtenção do licenciamento da construção, a segunda 6 meses após e a terceira 18 meses a contar da data do licenciamento (FRANÇA, 1975).

O valor obtido com o pagamento da contrapartida era disponibilizado à municipalidade através de um fundo gerido pela pasta de investimentos, responsável pelo orçamento da prefeitura. Este seria dividido em quatro partes para financiar objetivos específicos, onde três quartos desta parte seriam destinados as despesas ou subvenções atribuídas para restauração de edifícios classificados ou inscritos; para restauração de edifícios inseridos no perímetro de um Secteur Sauvegardé; para constituição de espaços verdes; aquisição de terras visando a construção de habitação social; para a construção de habitação para aluguel destinadas a trabalhadores imigrantes, assim como, aquisições de terra realizadas no âmbito das Zone d'Intervention Foncière (ZIF) ${ }^{103} \mathrm{e}$ da Zone d'Amenagemant Differé (ZAD) ${ }^{104}$.

Uma exceção à regra do pagamento se aplicava a cidade de Paris, onde somente metade da contrapartida seria destinada a municipalidade, sendo que um quarto deste mesmo produto financiaria dois casos estritos, a saber: a constituição de espaços verdes e as ações que visassem valorizar uma política de habitação social destinada a amparar habitantes do centro da cidade em situação precária. Outra exceção dizia respeito ao pagamento no âmbito da ZAC, que deveria ser realizado pelo beneficiário da autorização de construção. Ressaltando que no caso da Zone d'Aménagement Concerté,

[...]a densidade das construções existentes e a superfície tomada em consideração por determinar se as construções novas iriam superar o Plafond

\footnotetext{
102 O valor do terreno era estabelecido com referência ao valor de mercado declarado no momento da aquisição da licença de construção (esta era controlada pelas autoridades fiscais) (GILLI,1975).

103 Instituída em 1975 a ZIF era uma área classificada como "urbana" por um plano de uso da terra (POS) e estava automaticamente sujeita ao direito de preferência por um período ilimitado (MONTANDON, 2009).

${ }^{104}$ A ZAD era uma área sujeita ao procedimento administrativo que permitia a constituição de reservas de terras, na perspectiva mais ou menos distante de expansão ou renovação urbana (MONTANDON, 2009).
} 
Légal de Densité, bem como o valor da terra, seriam apreciados igualmente pelo todo da zona ${ }^{105}$ (FRANÇA, 1975. Art.12).

Os objetivos atribuídos à implantação do PLD, como, por exemplo, a redução de densidade das áreas centrais e o aumento de recursos a nível local, mostraram-se ao longo dos cinco primeiros anos insatisfatórios. Pois a intenção original de dissociar o direito sobre o solo do direito sobre o espaço não prevaleceu por razões constitucionais, tendo adotado, ao final, uma concepção fiscal. Neste período, também foi possível observar, que o PLD fez com que os incorporadores se adequassem ao limite imposto, orientando suas atividades para obras de recuperação de edificações em áreas centrais contribuindo assim, indiretamente, com a preservação de edifícios históricos. Como consequência, o poder público conseguiu obter um pequeno volume de recursos por intermédio da aplicação do instrumento (GRANELLE, 1981).

Em 2010, o PLD foi abolido em favor de um novo mecanismo fiscal, o Versement Pour sous Densité (VPD). Este funciona inversamente ao Plafond Légal de Densité, pois é responsável por taxar a subutilização do potencial do terreno nas zonas urbanas e a urbanizar (LE BAYON et al., 2013). Porém, não iremos discorrer sobre este tema, posto que nosso objetivo em estudar o PLD, nos seus primórdios, se concentrou no fato de analisar um instrumento que serviu de embasamento para a formulação do Solo Criado, que viria a ser posteriormente a base para elaboração da Transferência de Potencial Construtivo que é o objeto de estudo deste trabalho e, demonstrar que o instrumento do Plafond Légal de Densité foi formulado, também, como um incentivo a conservação do patrimônio cultural e era passível de ser aplicado tanto nos setores salvaguardados quanto na ZAC, não estando portanto, atrelado a nenhum outro instrumento mas sim, trabalhando como uma subvenção vinculada a política urbana (FURTADO et al., 2011).

Vimos, nos exemplos acima, que na França a responsabilidade por promover e gerenciar projetos para centros históricos, como no caso da área central de São Paulo, é do governo federal. Este disponibiliza uma forma de proteção através da delimitação de um perímetro, o Secteur Sauvegardé, onde os imóveis de interesse histórico e cultural dispõe de incentivos para sua conservação e restauro bem como de diretrizes para obras na respectiva área.

105 Tradução da autora. 
Já as áreas de entorno dos bens tombados nos casos que em estas se superpõe, são extintas e tratadas num contexto de zona, cuja responsabilidade fica por conta de uma, ou várias, Comuna com apoio do governo federal. Este tipo de delimitação seria muito interessante para o caso da área que circunda 0 centro histórico de São Paulo, a qual não dispõe de uma grande quantidade de edifícios tombados, mas que complementam a paisagem circundante a estes e que também necessitam de proteção e incentivos para sua conservação, mas que contudo, dispõe de setores passíveis de desenvolvimento urbano.

E, para finalizar, analisamos também as Zones d'Aménagement Concerté (ZAC) cujo princípio básico de funcionamento é promover o desenvolvimento de áreas subutilizadas, o que não é totalmente o caso da área central de São Paulo. Mas se considerarmos que a Operação Urbana teve como referência o instrumento francês da ZAC, pensamos que a Operação Urbana Centro não deveria ter sido implantada na região central que engloba o miolo histórico considerando que esta já é uma área desenvolvida do ponto de vista construtivo.

\subsection{Estados Unidos da América, entre planos e projetos}

Neste trecho do trabalho nos propusemos a estudar três projetos norteamericanos que tiveram influência na política de preservação do patrimônio daquele país. O primeiro, fomentado pelo órgão federal responsável pela preservação do patrimônio cultural, visava promover a conservação e valorização dos bens culturais, no nosso caso de estudo, os edificados, através da disponibilização de incentivos, desde que os estados implementassem um plano de preservação. Já o segundo projeto estudado, vem ao encontro da necessidade que temos, no presente trabalho, de conectar a salvaguarda patrimonial através de desenvolvimento urbano, posto que este é um dos assuntos aqui discutidos. E, por último, nos propomos a analisar o instrumento urbanístico Space Adrift formulado no contexto do Chicago Plan, que foi uma proposta realizada visando contribuir com a preservação do patrimônio a nível local. 
O plano ${ }^{106}$ solicitado pelo órgão responsável pelo patrimônio nos Estados Unidos da América (E.U.A.), diferentemente daquele realizado pelo Ministério da Cultura na França, não envolve um desenho de cidade nem a demarcação de perímetro. O plano, no caso norte-americano, se refere a planejamento de projetos, muito utilizado quando uma agência governamental se propõe a fazer ou construir algo. O plano tem por objetivo prever os impactos potencialmente adversos que poderão ocorrer ao longo de determinado período (STIPE, 2003).

A necessidade de efetivação do plano para recebimento de subvenções está prevista em lei, apesar disto, não existe uma legislação específica, como no caso francês do Secteur Sauvergadé, de regulamentação. O delineamento de sua formulação fica a cargo da agência estatal de preservação responsável por este, e devido a isto, no interior do documento que compõe o plano, podemos analisar diferente aproximações para um mesmo assunto. E, considerando, ainda, o fato de que o plano também pode ser realizado a pedido do State Historic Preservation Office (SHPO) por uma universidade, logo, os miolos de plano podem variar consideravelmente de estado para estado, porém, todos almejam o mesmo objetivo, que é demonstrar a necessidade de arrecadar subvenções para a preservação de seu patrimônio cultural (STIPE, 2003).

Como vimos no capítulo anterior, em 1966, foi promulgada a lei intitulada National Preservation Act $^{107}$, responsável por disponibilizar fundos para os estados norte-americanos realizarem programas de preservação, assim como providenciou subsídio de 50\% para preservação de sítios e edifícios históricos desde que cada estado preparasse um plano de preservação. Os estados são os responsáveis por redistribuir as concessões, tanto para os governos locais, quanto para entidades privadas, contudo, o State Historic Preservation Office (SHPO) local é o responsável por garantir o cumprimento das condições de concessão. O Statewide Historic Preservation Plan (SHPP) ${ }^{108}$ deve ser preparado para prever um futuro estimado entre dez e quinze anos de implementação e, deve ser atualizado a cada 5 anos como

\footnotetext{
106 Instituido pelo National Historic Preservation Act, secção 106 (EUA, 1966).

107 A lei está ativa atualmente.

108 Plano Estadual de Preservação Histórica. Conforme diretriz do National Preservation Service o plano deve ser elaborado no período máximo de dois anos. Tradução da autora.
} 
condição para receber a concessão do Historic Preservation Fund (HPF) ${ }^{109}$ (E.U.A., 1966).

Segundo os requerimentos do NPS, o plano deve envolver a participação pública e deve incluir: um resumo do processo de planejamento, um cronograma, a avaliação resumida dos recursos históricos e culturais, estar conectado com uma visão prospectiva de preservação do patrimônio cultural, deve conter metas e objetivos a serem alcançados conjuntamente entre órgãos do governo estadual e local, entidades privadas e a comunidade. Para isso, é realizado um chamamento à população para que contribuam com sua elaboração, seja pelas redes sociais, pelos sites governamentais, através de reuniões e, para que se disponibilizem, posteriormente, a cooperar para a efetivação deste através de contribuição voluntária (CALIFORNIA STATE PARKS, 2013).

O requisito primordial para uma propriedade ser elegível a receber a concessão recai sobre a mesma se encontrar listada no National Register of Historic Places (NRHP) e se encontrar identificada no SHPP, desde que este tenha sido aprovado pelo NPS. Como contrapartida ao recebimento da concessão a propriedade deverá ficar acessível ao público. A acessibilidade depende de quais elementos significativos compõem o patrimônio, se forem somente externos, então o público deverá ter total acesso para contemplar o bem cultural de qualquer ângulo da via sem obstruções. Agora, se o ambiente interno também contiver elementos significativos este deverá ser disponibilizado, considerando um calendário de visitas, ao acesso público.

A realização da concessão só é permitida se o imóvel não estiver recebendo fundos de outras atividades ou programas federais. O imóvel pode utilizar, ainda, benefícios concedidos pelo governo local como a transferência do direito de construir ${ }^{110}$, alívio regulatório (variações) na conformidade com os códigos de construção atuais e restrições de planejamento ou zoneamento, isenções de taxas, e programas de concessão ou empréstimo com juros baixos que possam fornecer estímulo econômico no nível local. As despesas elegíveis para a concessão federal

\footnotetext{
109 O fundo fornece subsídios aos escritórios de preservação histórica estaduais e tribais direcionados aos trabalhos de levantamentos de recursos históricos, treinamento, nomeações para o Registro Nacional de Lugares Históricos e subsídios para as jurisdições locais incentivarem os trabalhos de valorização e conservação do patrimônio. Disponível em: www.nps.gov. Acesso em: 12 jun. 2017 110 No original: Transfer development rights.
} 
são: restauro de fachadas, consolidação estrutural, serviços de instalações elétrica e hidráulica. As despesas com restauro de interiores só podem ser financiadas caso o imóvel tenha sido objeto de preservação total, ou seja, classificado pelo National Register. Ao receber o incentivo do governo o proprietário fica atrelado a algumas responsabilidades, por exemplo, se o imóvel foi comprado com dinheiro obtido através da concessão o estado deve ser o primeiro a recusar a compra caso o proprietário queira vendê-lo, ou, no caso de transferência de propriedade entre parentes o governo federal também deverá ser comunicado (COSTONIS, 1975).

O Statewide Historic Preservation Plan é o único meio que o governo estadual e local, as comunidades e as entidades privadas tem para obter incentivo concedido pelo NPS. Contudo, existem outros fundos de agências federais destinados a contribuir com a preservação do patrimônio cultural, porém, são excludentes, o que pensamos ser uma forma de controle para a destinação de verbas pelo governo central. Apesar do SHPP ser um plano abrangente, diferentemente do PSMV para os setores salvaguardados franceses, este em nenhum momento faz alusão a concessão de incentivos para os centros históricos ${ }^{111}$ como um modo de preservação de um conjunto com características significativas do ponto de vista patrimonial que é o caso do plano francês. Os centros históricos dos E.U.A., nas pesquisas que realizamos, são sempre tratados por projetos a nível local, e, salvo raras exceções, nunca como objetivo em si, mas sempre dentro de um contexto mais amplo de programas, por exemplo, habitacionais e de espaços públicos.

\subsubsection{O controverso Urban Renewal Program}

A preservação do patrimônio histórico através do planejamento urbano teve, nos E.U.A., um dos casos mais controversos da literatura, pois um dos programas responsáveis por disponibilizar incentivos à preservação foi o mesmo responsável por incentivar a demolição de edifícios históricos. Como foi relatado no início deste capítulo, o programa realizado pelo Department of Housing and Urban Development

\footnotetext{
111 Os centros históricos são regulados pelas Comissões locais e assim como outras construções são passíveis de receberem concessão através do Historic Preservation Program, mas sempre cada construção por si só. (em inglês: Landmark Preservation Board)
} 
(HUD) ${ }^{112}$ iniciou programas de remoção de cortiços de áreas centrais por todo o território norte-americano, contudo, também foi responsável por disponibilizar incentivos para a preservação do patrimônio construído.

O Urban Renewal Program foi iniciado com a aprovação do Housing Act, em 1949, e previa incentivos às demolições e construções de edifícios, entre outros, para uso habitacional. Muitas foram as críticas ao programa, censurado por ações como demolições de quarteirões inteiros (históricos em grande parte dos casos) e remanejamento de população local, e, devido a isso, podemos encontrar na legislação americana uma série de alterações a lei inicial. Com o passar dos anos o programa se tornou mais "flexível", e questões relativas a reabilitação e conservação do patrimônio construído foram colocadas em pauta (LEACH, 1960).

Após 1970, o programa passou a focar mais a questão da preservação de edifícios com relevância histórica e arquitetônica, e os governos locais passaram a receber concessões da agência federal para financiar obras de restauro, conservação entre outras correlatas. O Urban Renewal Program era um programa local sustentado financeiramente pela agência federal (HUB) onde cidades com mais de 50.000 habitantes recebiam subvenção, através da agência local de redesenvolvimento, para cobrir dois terços dos custos permitidos e, cidades com 50.000 (cinquenta mil) habitantes ou menos, recebiam três quartos. Porém, o valor máximo do custo com obra de restauro permitido era de $\$ 90.000$ (noventa mil dólares), por edifício (COSTONIS, 1975).

A assistência era disponibilizada somente aos imóveis que estivessem contidos no perímetro do programa e cujas obras de restauro/manutenção se encontrassem dentro dos parâmetros definidos pelo National Register, contudo não era obrigatório que estivessem listados. Ainda assim, a localidade deveria garantir a agência federal que o imóvel manteria suas características arquitetônicas e históricas para assim receber a concessão (TARNE, 2010).

Sob as condições do Urban Renewal Program as atividades financiadas eram: assistência técnica para os trabalhos de restauro, aquisição de imóveis e realocação de propriedades, desde que se mantivessem no perímetro do programa, e fossem de

112 Responsável por realizar o Urban Renewal Program através do Housing Act 1949 - Public Law 17163 Stat. 413 (E.U.A, 1949). 
propriedade pública. A agência local poderia, posteriormente, vender o imóvel, mas, neste caso, o restauro aprovado para concessão, independente do grau de preservação do imóvel, seria somente para as fachadas (elemento disponível para apreciação pública).

O Urban Renewal não foi um programa implementado para resguardar o patrimônio construído dos centros históricos, vê-se pelo contexto de distribuição de subvenção considerando a quantidade de habitantes por cidade. A associação de questão patrimoniais ao longo dos anos pelo programa foi de encontro às duras críticas que o mesmo havia sofrido em seu período inicial e, também, pelo fato do governo norte-americano vislumbrar o bem cultural como um ativo na economia da nação. Pois segundo estudo realizado na época o restauro de um edifício era mais lucrativo para o incorporador imobiliário que a construção de uma habitação nova. (TARNE, 2010).

Apesar do programa ter sido fomentado por uma agência de desenvolvimento urbano, verificamos que o patrimônio construído continuou relegado aos trabalhos usuais de restauro e conservação sem conexão com a questão urbana: da paisagem, dos volumes e do bem cultural como parte de um conjunto, algo que foi melhor definido pelos programas franceses já estudados neste trabalho.

O governo norte-americano, através de suas agências federais, estaduais e locais, dispõe de alguns programas voltados a contribuir para a preservação do patrimônio cultural, porém, poucos são aqueles que delimitam um perímetro de intervenção cujo foco principal é a salvaguarda do patrimônio. A regulamentação de ações que venham a considerar as pré-existências num contexto de desenvolvimento urbano é realizada na maioria dos casos pelas municipalidades através de zoneamento.

\subsection{Space Adrift, incentivo para preservação de quarteirões históricos}

Nos Estados Unidos, a regulação do uso do solo historicamente foi delegada aos governos locais, juntamente com o poder de implementar os planos. Em essência, 
o governo federal atua estritamente com o escalão mais alto da regulação de terras, não podendo intervir nas regulamentações estatais. $E$ isso tudo devido a formulação da Constituição Nacional que, quando de sua criação, buscou não interferir com as legislações estaduais existentes. Sendo assim, os estados têm formulado leis que delegam a atribuição de regulamentar o solo para as municipalidades (SUTTON, 2008).

A municipalidade é, nos estados norte-americanos, o ponto de partida para qualquer pesquisa sobre programas de preservação. Apesar dos bens culturais terem reconhecimento nacional, e até internacional, é nas cidades que eles encontram sua significação inicial, enriquecendo o tecido urbano e a vida dos residentes, definindo o caráter de um local para seus possíveis visitantes. E por esta razão eles devem figurar no planejamento e zoneamento das cidades, pois, se estas não preservarem e valorizarem seu patrimônio, este será perdido (COSTONIS, 1975).

O Estado de Nova lorque implantou em 1916 o primeiro zoneamento restritivo. Visando preservar seus edifícios históricos, este estabelecia um "zoning envelope" para cada local, delimitando recuos bem como área de construção, porém, não colocando limites para a densidade populacional nem para a altura dos edifícios que estivessem dentro do envelope. Este caso levantou precedentes para o restante do país e, alguns outros estados passaram a utilizar o zoneamento como forma de preservar certas porções de seu território (BARNETT, 1974; BAKER, 1975).

A passagem do movimento City Beautiful, o qual buscou controlar o desenvolvimento urbano, coincidiu com as primeiras manifestações do controle público sobre as decisões do desenvolvimento privado. Quando da ocorrência do movimento, as cidades prescindiam da "resolução de dicotomia de eficiência e equidade em favor das forças do mercado" (BAKER, 1975, p.135), com resultados que favoreciam os interesses econômicos do mercado da incorporação imobiliária. $A$ regulação através do zoneamento passou a conflitar com os interesses dos proprietários de terra urbana, empenhados em maximizar os lucros através do máximo desenvolvimento de suas propriedades.

Um exemplo muito conhecido historicamente, quando a preservação do patrimônio construído interferiu nos interesses do mercado imobiliário, devido à publicação para a qual o caso serviu de base (COSTONIS, 1975), foi a questão do 
Chicago's Old Stock Exchange. Este edifício foi demolido, em 1972, para dar lugar a uma nova construção que abrigaria um prédio, com 45 pavimentos para salas de escritórios. Porém, o edifício a ser demolido não era só mais um na paisagem da cidade, este havia sido projetado por Louis Sullivan e Dankmar Adler, em 1869, e era um dos exemplares mais significativos da Escola de Arquitetura de Chicago ${ }^{113}$ (WEINBERG,1979).

A polêmica em torno da possível demolição suscitou algumas propostas e, entre elas, a possibilidade de transferência do potencial construtivo ${ }^{114}$ para um lote adjacente ou mesmo para um lote distante, pois esta ação poderia diminuir o impacto financeiro caso a construção fosse listada pelo National Register ${ }^{115}$. Porém, as opções não foram aceitas pelos incorporadores e proprietários, e o prédio foi demolido. Contudo, o caso levantou a discussão acerca do que poderia ser realizado para compensar os proprietários de edifícios históricos e com isso nasceu a publicação, Space Adrift: Landmark preservantion and the marketplace.

Iremos discorrer sobre esta publicação pois a mesma deu origem ao instrumento Space Adrift cuja base serviu de exemplo para a formulação do Solo Criado. Na realidade, o que podemos afirmar de antemão sobre a relação do instrumento norte-americano com o Solo Criado se baseia na interlocução estabelecida entre os protagonistas de ambos instrumentos. Pois John Costonis, idealizador do Space Adrift, segundo o professor José Eduardo de Assis Lefèvre ${ }^{116}$, esteve em São Paulo na sede Coordenadoria Geral do Planejamento da Prefeitura Municipal de São Paulo (COGEP/PMSP) para realizar palestra e fazer reuniões com Domingos Theodoro de Azevedo Netto, um dos idealizadores e defensores do Solo Criado em São Paulo. Logo, se o instrumento brasileiro sofreu influência ou não do

\footnotetext{
${ }^{113}$ Movimento artístico desenvolvido nos finais do século XIX que se constituiu como uma das primeiras manifestações da arquitetura moderna cujos edifícios foram construídos com soluções tipológicas e estruturais avançadas para a época, fazendo uso de estruturas metálicas simples e desenho de fachadas funcionais (CONDIT, 1998).

${ }^{114} \mathrm{~A}$ transferência de potencial construtivo não era legalmente instituída na cidade de Chicago.

115 Infelizmente o edifício não havia sido listado ou mesmo indicado ao National Register, contudo, após o anúncio da eminente demolição alguns arquitetos preservacionistas se reuniram e formularam um dossiê que serviu de documento para que a construção fosse indicada ao registro, porém mesmo assim ela acabou sendo demolida.

116 Arquiteto e Urbanista, trabalhou entre os anos de 1976-2001 na COGEP sob supervisão de Domingos Theodoro de Azevedo. Em entrevista realizada pela autora, em janeiro de 2018, este afirmou ter participado de uma palestra realizada pelo advogado norte-americano, John Costonis, na sede da COGEP - Prefeitura Municipal de São Paulo, cujo tema era Space Adrift.
} 
Space Adrift só poderemos falar por meio de uma análise comparativa, porém, sabemos que os idealizadores mantiveram contata acerca dos temas (DALEFFE, 1997; ALOCHIO, 2008; FURTADO et al., 2011).

O Space Adrift ${ }^{117}$ foi um dos instrumentos discutidos no âmbito do Chicago Plan, proposto por John Costonis (1975), e partia da premissa que a maioria das áreas históricas tinham quatro características em comum: elas utilizavam apenas uma fração de solo da área autorizada para seus locais sob o zoneamento; elas eram capacitadas a operar com lucro; geralmente estavam agrupadas em solo com alto valor comercial e num distrito bem provido por serviços municipais e de suporte, permitindo que um grande número de pessoas utilizassem o espaço eficazmente, somando todos, estes fatores fariam com que o solo concentrado nestas áreas fosse valorizado como um local para desenvolvimento. $O$ autor propunha que o potencial de desenvolvimento destas áreas pudesse ser transferido para outros locais, permitindo assim a preservação de construções históricas (COSTONIS, 1975).

O Chicago Plan recomendava a criação de distritos de transferência do potencial construtivo, locais estes que detinham a maior concentração de bens culturais edificados e que seriam designados pelo zoneamento. O proprietário de um edifício histórico preservado poderia transferir o potencial construtivo não utilizado para outro distrito, estando sujeito ao atendimento de coeficiente de aproveitamento, altura e outros controles de planejamento prescrito por regulamento. O potencial construtivo poderia, também, ser transferido para outro terreno do mesmo proprietário ou vendido para alguém interessado em construir num outro lote. Após a transferência do potencial, o proprietário do imóvel preservado ainda teria direito a uma dedução de imposto sobre o imóvel, como compensação pelo baixo valor produtivo que o imóvel passaria a ter após a transferência. Todavia, antes de realizar a transferência a municipalidade exigiria que o proprietário declarasse, por escrito, seu compromisso e, de futuros proprietários, a preservar o bem, sem alterá-lo ou demoli-lo (COSTONIS, 1975).

Supondo que o proprietário rejeitasse transferir o potencial e insistisse em construir sem permissão, neste caso a municipalidade poderia emitir uma restrição de preservação, invocando um poder legal, e adquirir o direito de propriedade do imóvel.

117 Espaço flutuante. Tradução da autora. 
Com isso, o potencial construtivo seria capturado pelo governo local e depositado num "banco de transferência de potencial construtivo", para serem vendidos a proprietários de outros lotes. O banco também seria utilizado recebendo doações de potencial de imóveis pertencentes a proprietários privados, bem como para capturar a transferência de potencial de imóveis públicos (COSTONIS, 1975).

A princípio o banco necessitaria de um fundo inicial a ser disponibilizado pela cidade, o autor não especifica de onde viria este valor. Posteriormente, a reserva seria provida com a transferência de potencial construtivo. Assim, a cidade poderia aproveitar de um recurso, anteriormente inativo, para uma finalidade pública. Segundo o plano, a maior parte dos custos da municipalidade com a preservação de edifícios poderiam ser pagos com a venda de potencial construtivo de edifícios ameaçados (a primeira categoria acima relatada). O banco poderia também subsidiar o custo restante de obras de restauro que ultrapassassem o valor da transferência obtida por um imóvel.

Entendemos que a transferência poderia ser realizada por imóveis que não fossem listados ou classificados, desde que este pertencesse a um distrito com interesse histórico. Pois, se o proprietário, conforme relatado acima, poderia não aceitar transferir o potencial e construir mesmo assim, isto significa que o imóvel não necessitaria ser objeto de salvaguarda pelo órgão de preservação para que pudesse realizar a transferência. E outra questão que nos faz suscitar esta hipótese vem do episódio com o Chicago's Old Stock Exchange, que não era objeto de preservação por parte do National Register, e cujo caso serviu de base para o estudo do Space Adrift. Já os imóveis que fossem designados a comporem a lista do National Register, teriam um relatório contendo descrição pormenorizada de seu estado de conservação, e qual valor necessário para seu restauro ou manutenção. Com esta base, a comissão de monumentos local se encarregaria de disponibilizar um pacote de subsídios financiados pelo banco de potencial construtivo para que fossem realizadas as obras necessárias.

O objetivo do Chicago Plan era eliminar a necessidade de dispensa em larga escala dos fundos municipais. Projetado para forçar o processo de desenvolvimento urbano, responsável por criar uma enorme pressão no patrimônio cultural edificado, o plano previa a transferência de potencial construtivo tanto como uma compensação 
ao proprietário do imóvel tombado quanto como forma de desenvolver outras áreas da cidade. Porém, o aumento de densidade nessas áreas resultaria em encargos para a municipalidade com sistemas de infraestrutura urbana, por isso, o autor, em seu plano, exigia que estes encargos fossem assumidos pelo comprador do potencial construtivo e que este também se comprometesse a assumir outros encargos decorrentes do aumento de densidade.

Apesar do plano ter sido muito bem formulado, questionamos o alcance que os fundos providos pelo banco de potencial construtivo poderiam atingir, pois só seria possível exigir dos compradores todas estas contrapartidas caso tivesse certeza absoluta da negociabilidade do potencial construtivo em mercado. $E$, além disso, somente se os interessados fossem obrigados a comprarem o potencial construtivo diretamente do banco, em vez de realizarem transação direta com os proprietários de bens culturais, esses controles seriam passíveis de realização. Considerando estas questões, entendemos que a transferência direta de potencial construtivo não poderia ser permitida neste caso.

O Chicago Plan trouxe elementos interessantes e inovadores, procurando alterar o ônus econômico da preservação do patrimônio cultural, sempre relegado a grupos específicos como órgãos governamentais, grupos e entidades preservacionistas, no caso norte-americano; deslocando para um mercado de transferência de potencial construtivo que poderia resolver o problema com um custo mínimo para o público. Contudo, este não foi implementado em Chicago, logo, não é possível analisar se de fato ele alcançou seus objetivos (WEINBERG, 1979).

Neste capítulo nos propusemos a analisar a perspectiva internacional na preservação do patrimônio cultural edificado, tomando como exemplo alguns projetos na França e nos Estados Unidos da América, por vias do desenvolvimento urbano. Pudemos apreender que no caso francês existiu uma política nacional de preservação de centros históricos, que em seu modo mais restritivo chegava a suplantar o plano urbano local. Vimos também, ainda na França, uma tentativa de aproximação e compartilhamento da função de salvaguarda com a implementação das ZPPAUP. Mas, um plano urbanístico, com caráter desenvolvimentista, que é caso da ZAC, não tem como foco a preservação de edificações históricas, é possível, sim, que este aceite concessões que permitam a preservação de alguns elementos arquitetônicos, 
mas quando se trata de um conjunto histórico o responsável por delinear as premissas ainda é o órgão de preservação competente.

No caso norte-americano, vimos que existe o interesse em salvaguardar os bens de interesse histórico e cultural através de um plano de proteção, porém este plano não é realizado para um conjunto de imóveis históricos, mas sim para os conjuntos dos imóveis históricos pertencentes ao estado, ou a comunidade local, desconsiderando a questão da inserção urbana. O patrimônio cultural edificado é tratado como um elemento que contribui para o enriquecimento cultural, e por que não, econômico, da cidade e por isso deve ser preservado. No Urban Renewal a disponibilização de incentivos para a conservação dos imóveis foi tratada como uma forma de mostrar a população e aos órgãos competentes que o programa se importava com as pré-existências, entretanto não via nestas um meio para o desenvolvimento das cidades. As concessões eram realizadas pontualmente sem conectar os elementos transformando-os em conjunto para assim promover a salvaguarda dos imóveis protegidos, aliando-as ao desenvolvimento urbano.

A escolha dos projetos aqui estudados teve por objetivo demonstrar como estes dois países, cujos instrumentos urbanísticos viemos a utilizar de base para a formulação do Solo Criado, lidam com seu patrimônio cultural urbano e como ambos incentivam a preservação dos imóveis protegidos através da implementação de planos e projetos. A análise se fez necessária para que busquemos compreender o contexto de inserção da Transferência de Potencial Construtivo no cenário da Operação Urbana Centro. 
Capítulo III - OPERAÇÕES URBANAS E OS BENS PROTEGIDOS NA ÁREA CENTRAL DE SÃO PAULO 


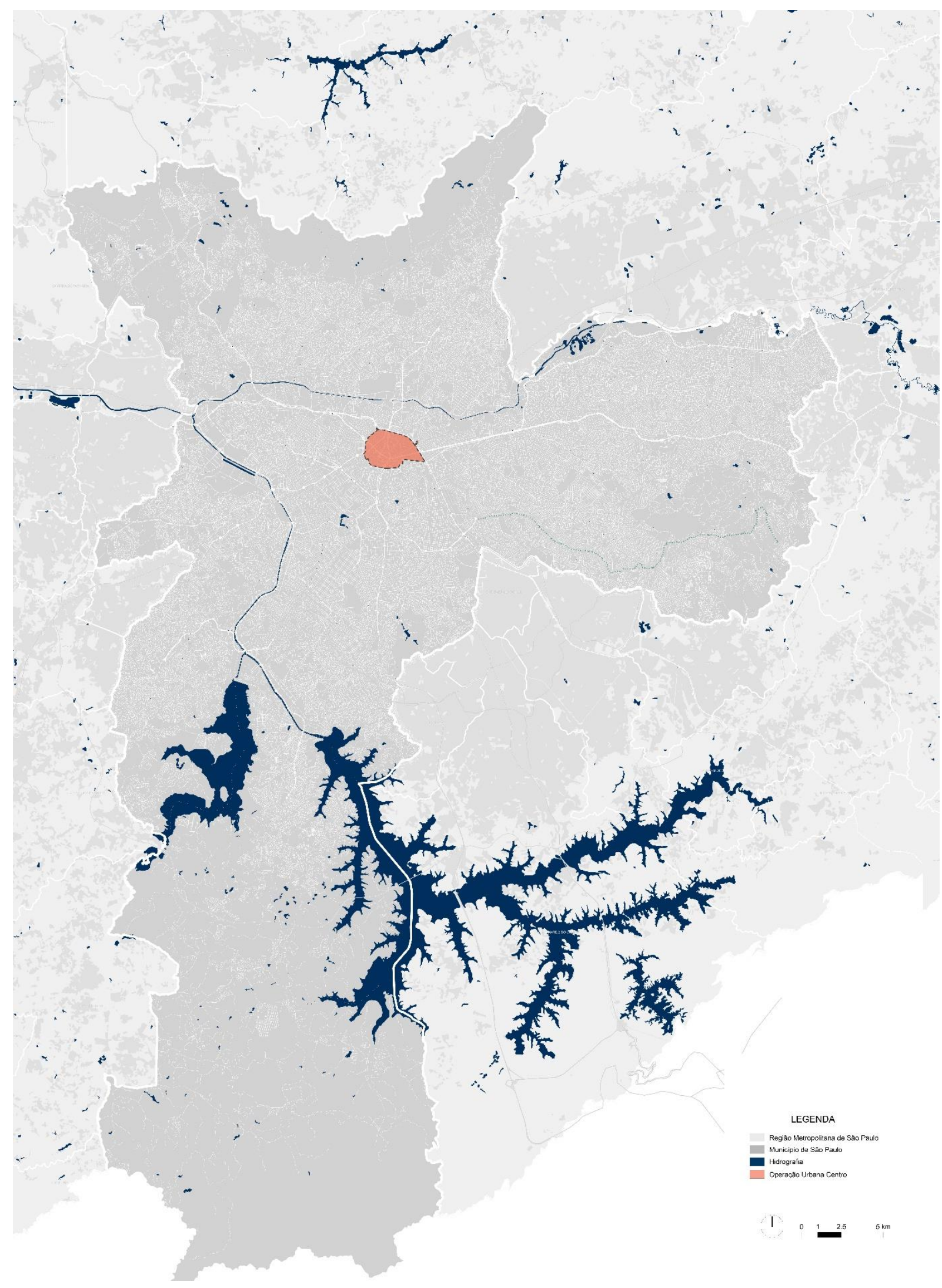

Figura 3.1 - Mapa de localização da Operação Urbana Centro em relação a cidade. Tabulação da autora. Fonte: Plano Diretor 2014 sobre base do Mapa Digital da Cidade de São Paulo, 2017. 


\subsection{O debate do Solo Criado}

No início de 1970, surgiu no Brasil um novo instrumento de incentivo e controle à política fundiária. Podemos dizer que sua origem está associada a dois tipos diferentes de análise dos efeitos da regulação pública do uso do solo. Na França, bem como em outros países europeus, constatou-se que os limites impostos pelos instrumentos urbanísticos existentes, basicamente o zoneamento, já não eram capazes de conter a elevação dos preços da terra, dos imóveis, dos equipamentos e serviços urbanos e, assim, foram instituídos mecanismos para reverter a segregação causada pela baixa oferta de terra urbana e pela crescente alta dos preços do solo. E, nos Estados Unidos da América, surgia o interesse em preservar os edifícios históricos através da venda de seu potencial construtivo (CARDOSO; RIBEIRO, 1992).

Em São Paulo, a experiência e os debates acerca do Solo Criado surgiram em 1975, num encontro promovido pelo Grupo Executivo da Grande São Paulo (GEGRAN), que, desde 1974, tinha iniciado estudos relacionados ao controle do uso do solo, entre seus técnicos e consultores, a nível metropolitano. Em 1974, também foram propostas as implantações da transferência de direitos de construção e do coeficiente de aproveitamento para controle de uso do solo, em relatório efetuado por Domingos Theodoro de Azevedo Netto, a pedido do então futuro governador do Estado de São Paulo, Paulo Egydio Martins, no contexto de uma série de estudos preparatórios de seu governo (CJ ARQUITETURA, 1976).

A lei que criou as regiões metropolitanas (Lei XIV) criou também o conceito de uso do solo a nível metropolitano. O controle do uso do solo a nível metropolitano é uma questão bastante difícil de responder. Há, entretanto, consenso em salvaguardar a nível metropolitano, o essencial, e deixar o acidental, o característico do detalhe, para o nível municipal.

Ao se procurar aprofundar este consenso, houve um grande amadurecimento sobre as questões relativas ao uso do solo em si mesmo. Desse amadurecimento, dessa reflexão profunda, surgiu o conceito da criação de solo que aproveitou também estudos em desenvolvimento no mundo inteiro'118 (CEPAM, 1975, p.9).

118 Grifo da autora. 
Aproximadamente um ano após a realização dos estudos acima citados, é publicado um documento intitulado "Solo Criado". Concebido pelo Centro de Estudos e Pesquisas da Administração Municipal (CEPAM), o estudo foi elaborado pelos técnicos Domingos Theodoro de Azevedo Netto, Clementina de Ambrosis, Antônio Claudio Moreira Lima e Dalmo do Vale Nogueira Filho, e neste foi utilizada pela primeira vez a expressão: "Solo Criado"119. Visando controlar o uso do solo frente a pressões políticas e econômicas, o trabalho propunha a implementação de três novos instrumentos: o coeficiente de aproveitamento único, a transferência dos direitos de construção e a proporcionalidade entre áreas construídas (CEPAM, 1975).

O coeficiente de aproveitamento seria a fixação de um mesmo índice para todos os terrenos num município, região ou país. Atrelado a este instrumento estaria o direito de construção, que ficaria limitado a uma determinada quantia proporcional a área do terreno. A possibilidade de construir além desse direito seria possível mediante aquisição de direito de construção de outros terrenos, ou seja, pela transferência do direito de construção. A transferência poderia ser realizada quer pela aquisição dos direitos de construção do Poder Público, neste caso, por uma transação monetária, ou pela oferta de outros terrenos de interesse da comunidade (CEPAM, 1975).

A transferência dos direitos de construção que, segundo o documento, não seria novidade posto que nos Estados Unidos da América (E.U.A.) já vinha sendo utilizada para a conservação do patrimônio histórico, tinha como pressuposto permitir a transferência de um lote para outro desde que observasse as seguintes regras: o proprietário de um imóvel tombado poderia vender seus direitos de construção, desde que não tivesse extrapolado o coeficiente de uso do solo, para o poder público municipal, caso este estivesse interessado em preservar o imóvel em questão ${ }^{120}$, ou para um proprietário particular cujo lote fosse permitido aumentar o coeficiente de aproveitamento. Em caso de venda para a municipalidade, esta ficaria encarregada de revender o direito de construção a outro interessado (CEPAM, 1975).

\footnotetext{
119 "Do ponto de vista prático, poderá ser considerado Solo Criado apenas a área construída que ultrapassar um certo valor, fixado em função da problemática global do uso do solo numa dada comunidade." (CEPAM, 1975, p. 15)

120 Considerando que o Conselho Municipal de Preservação do Patrimônio Histórico, Cultural e Ambiental de São Paulo (CONPRESP) responsável pela deliberação de tombamento do patrimônio cultural em São Paulo só foi instituído em 1985. (SÃO PAULO, 1985)
} 
Segundo o proposto no documento em análise, a transferência seria permitida para lotes vizinhos, lotes que fizessem frente ao cedente ${ }^{121}$ e lotes cuja distância não excedesse $100 \mathrm{~m}$ deste. Posteriormente, a permissão de transferir poderia ser estendida para toda a cidade desde que fosse determinado um plano designando as premissas necessárias para os lotes receptores. A operacionalização do instrumento seria regida por uma Certidão de Registro de Imóveis referente à compra, ou à venda do direito de construir, a ser solicitada pela Prefeitura quando do pedido de aprovação dos projetos no lote onde se pretendia construir a mais. O estudo, infelizmente, não detalha como seria calculada a venda do direito ou mesmo o que seria necessário para emissão da certidão. Fica em aberto, também, qual órgão da prefeitura seria responsável por comprar e vender o direito de construir, assim como, onde ficaria depositado o valor auferido com a transação.

Constatamos que o estudo realizado pelo CEPAM, no que concerne a transferência dos direitos de construção, se aproxima do Space Adrift proposto pelo Chicago Plan. Chegamos a esta conclusão tanto por já termos analisado, no capítulo anterior, o instrumento supracitado, quanto pelas seguidas menções, que o trabalho realizado no âmbito do CEPAM faz, ao longo do texto da proposta desenvolvida no E.U.A. Contudo, não é possível fazer uma análise, nem muitos menos uma comparação pormenorizada, pois, no caso do estudo brasileiro, mais especificamente do município de São Paulo, não foram realizados, ao menos no documento ao qual tivemos acesso, detalhamentos que chegassem ao nível de cálculo para emissão da certidão de transferência (compra ou venda), ou mesmo de descrição dos diversos departamentos da prefeitura que seriam responsáveis por implementar a proposta para que pudéssemos comparar os dois instrumentos através de sua operacionalização.

No trabalho efetuado pelo CEPAM a transferência dos direitos de construção além de ser utilizada para a preservação do patrimônio histórico, poderia, também, ser utilizada para o patrimônio ambiental e áreas verdes. Considerando que, tanto uma residência de valor histórico quanto uma área verde localizada numa zona onde é permitida a construção de prédios com elevado gabarito viriam a sofrer com a pressão do mercado para ser demolida, ou ocupada, a fim de ceder lugar a uma

${ }^{121}$ Chamamos de cedente o lote passível de vender os direitos de construção. 
construção rentável. O instrumento nasce, assim, como um modo de garantir a valorização e preservação do patrimônio, frente à dinâmica urbana, ponderando que resquícios de área verde e imóveis de interesse histórico em áreas urbanizadas, geralmente, se encontravam em regiões de alto valor de uso, dada sua localização e serviços disponíveis.

É interessante ressaltar que, a discussão sobre a transferência dos direitos de construção para os imóveis de interesse histórico, foi iniciada antes mesmo de existirem imóveis preservados pelo município de São Paulo, já que somente em dezembro de 1975 foi aprovada a Lei n요, cujo texto versava sobre a listagem dos edifícios considerados históricos na área central da cidade e que, a partir daquele momento, passaram a ser protegidos pelo zoneamento através da categoria Z8-200 (SÃO PAULO, 1975).

A legislação aprovada em 1975, de regulamentação dos imóveis históricos, não delegava poderes aos órgãos responsáveis pela preservação para que estes impedissem que os bens fossem demolidos. E, considerando o processo de renovação pelo qual o centro de São Paulo passava naquele período, bem como as obras de implantação do metrô, era premente que fossem formatados mecanismos que contribuíssem para a preservação dos imóveis listados e, por isso, estes foram escolhidos como projeto-piloto para implantação do instrumento da transferência dos direitos de construção (EMURB, 1977).

Considerando os fatos acima relatados, em 1976 uma equipe ${ }^{122}$ do serviço do Patrimônio Histórico - Secretaria Municipal de Cultura em conjunto com técnicos da COGEP-EMURB, iniciaram estudos sobre a transferência dos direitos de construção para edifícios históricos, no caso aqueles definidos pela Lei de Zoneamento como Z8200. O trabalho foi composto por um diagnóstico físico-urbanístico das áreas envolvidas, para delimitar o universo de aplicação do instrumento. Na fase seguinte, foi desenvolvida uma metodologia de avaliação dos direitos de construir, para então num estágio posterior, tratar-se da proposta de lei (EMURB, 1977).

\footnotetext{
122 Num artigo publicado pela CJ Arquitetura no ano de 1977, Floriano Lima de Toledo informa ter sido procurado por arquitetos especialistas na área de História da Arquitetura para trocar ideias sobre a possível implantação de um método de conservação das edificações dotadas de interesse histórico. Esta seria uma adaptação do Space Adrift, a qual ele via como viável para o caso paulistano. Não conseguimos obter material que comprovasse a ligação deste estudo com o realizado pela COGEP posto que este foi paralisado em fevereiro de 1977 (CJ ARQUITETURA, 1977).
} 
A aplicação da transferência, segundo o estudo da COGEP, poderia se dar da seguinte forma: os direitos de construir do imóvel preservado seriam levantados através do potencial construtivo do lote, que era definido pelos regulamentos, como por exemplo, pelo zoneamento. Após a obtenção do valor dos direitos já utilizados no lote, o poder público compraria o restante e os venderia ao setor privado.

Este processo torna-se, portanto, auto-financiável, além de ter o poder de
ordenar urbanisticamente determinadas áreas, liberando outras no momento
em que esses direitos sejam transferidos. Desta forma não é necessário
estabelecer um Teto de Densidade Legal, ou mesmo estabelecer gabaritos,
uma vez que a ordenação urbana seria consequência do processo (EMURB,
1977, n.p.).

Realizado para analisar a viabilidade em implantar a transferência dos direitos de construção para os imóveis Z8.200. Em linhas gerais, o trabalho, por meio de cálculos e de uma metodologia proposta especificamente para este, foi realizado em três etapas: a primeira consistiu em analisar os imóveis através de um novo levantamento cadastral, pois a lei que instituiu a Z8.200 continha algumas falhas neste quesito. A segunda etapa foi concentrada na realização de cálculos matemáticos para visualizar a quantidade de potencial construtivo passível de transferência que cada imóvel continha e, com os valores encontrados, foi promovida uma estimativa monetária do valor que seria arrecadado com a venda do potencial construtivo dos imóveis pertencentes a Z8.200 (EMURB, 1977).

O estudo acima descrito, segundo o relatório da COGEP: RF 20/77 Compilação das análises desenvolvidas sobre o instrumento solo criado -, tinha como finalidade embasar um projeto de lei municipal que previa a implantação do instrumento, o qual seria o objeto da terceira etapa. Entretanto, antes que o mesmo fosse concluído, os trabalhos foram paralisados pois o poder público municipal optou por implantar diretamente o Solo Criado, passando a Transferência a ocupar um segundo lugar na escala de prioridade da COGEP (EMURB, 1977). Nota-se, assim, que o Solo Criado, anteriormente formulado como um conceito que englobava três instrumentos, passou a ser ele próprio um instrumento que contemplaria todos os imóveis com exceção dos históricos (C.J.ARQUITETURA, 1977).

Em abril de 1977, no jornal O Estado de São Paulo, foi publicada uma matéria informando que o prefeito Olavo Setúbal tinha enviado a proposta paulistana do Solo 
Criado para aprovação do governo federal e, caso este fosse aprovado, seria encaminhado a câmara municipal para prosseguimento. Este projeto de lei do Solo Criado é aquele cujo estudo a COGEP-EMURB ficou encarregada de realizar, em detrimento dos estudos sobre a transferência dos direitos de construção para imóveis tombados (ESTADO DE SÃO PAULO, 1977a).

O projeto de lei acima proposto foi realizado por Bernardo Ribeiro de Moraes ${ }^{123}$ e instituía coeficiente único igual a1 (um) para os lotes no município de São Paulo. Com isso, os proprietários de terreno somente poderiam construir uma vez a área do lote, caso desejasse construir além do estipulado, o proprietário deveria doar a prefeitura terrenos próximos a construção, que fossem de interesse da municipalidade, cujo valor venal fosse o mesmo do lote o qual se queria edificar, além do permitido, e com a metragem igual àquela que se queria ultrapassar. Caso os lotes a serem doados não fossem do interesse da prefeitura, o proprietário do terreno deveria pagar uma soma correspondente ao valor venal do metro quadrado que queria ultrapassar em seu lote. Esta soma, seria depositada em um Fundo, que iria financiar a aquisição de áreas verdes e as desapropriações para obtenção destas, bem como, para implantação de vias. (ESTADO DE SÃO PAULO, 1977a).

O excerto publicado no jornal, único material disponível atualmente sobre o tema, não fazia menção aos imóveis listados como Z8-200. Apesar do relatório composto pelos técnicos da COGEP-EMURB, em sua conclusão, atentar para o fato que existiria interesse em utilizar o instrumento na recuperação de edifícios antigos e que, devido a isto, a legislação deveria ser reformulada para evitar possíveis "brechas" o projeto de lei em nenhum momento faz alusão a este assunto (EMURB,1977). Entendemos que, foi neste período que a transferência dos direitos de construção, instrumento que nasceu como incentivo à conservação do patrimônio histórico, entre outras atribuições, deixa de ser foco de atenção pelo poder público em virtude da formulação de um instrumento mais rentável, o Solo Criado que poderia ser aplicado a todos os imóveis e cujo retorno financeiro à municipalidade, seria mais vantajoso.

123 Secretário das Finanças na gestão do prefeito Olavo Setúbal. 


\begin{tabular}{|c|c|c|c|}
\hline \multicolumn{4}{|c|}{ PROPOSTAS } \\
\hline & CEPAM & COGEP-EMURB & $\begin{array}{l}\text { PROPOSTA PAULISTANA } \\
\text { SOLO CRIADO }\end{array}$ \\
\hline $\begin{array}{l}\text { Como seria realizada a } \\
\text { Transferência: }\end{array}$ & $\begin{array}{l}\text { Transferência entre dois lotes ou } \\
\text { a 100m do imóvel histórico }\end{array}$ & & \\
\hline Beneficiados: & $\begin{array}{l}\text { Patrimônio histórico/ ambiental e } \\
\text { áreas verdes }\end{array}$ & Patrimônio histórico & \\
\hline $\begin{array}{l}\text { Comercialização da } \\
\text { Transferência: }\end{array}$ & $\begin{array}{l}\text { Poder público ou proprietário } \\
\text { particular }\end{array}$ & Poder público & $\begin{array}{l}\text { Doar terrenos à } \\
\text { Municipalidade ou pagar para } \\
\text { obter a área virtual }\end{array}$ \\
\hline Perspectivass futuras: & $\begin{array}{l}\text { Transferência para cidade toda } \\
\text { mediante elaboração de um } \\
\text { plano }\end{array}$ & & \\
\hline Forma de controle: & Certidão de registro de imóveis & & Fundo de gestão \\
\hline Forma de regulação: & & $\begin{array}{l}\text { Sem Teto de Densidade } \\
\text { Legal ou Gabaritos }\end{array}$ & C.A. $=1$ \\
\hline
\end{tabular}

Quadro 3.1 - Resumo das propostas para implementação da Transferência de Potencial Construtivo em São Paulo. Tabulação da autora. Fonte: CJ ARQUITETURA, 1975; EMURB, 1977.

\subsection{Antecedentes da Transferência de Potencial Construtivo, a Lei no9.725 e a Operação Urbana Anhangabaú}

Em agosto de 1977, foi divulgado que a prefeitura de São Paulo iria implantar o Solo Criado apenas parcialmente através da transferência do direito de construção para imóveis Z8.200. Porém entre 1978 e 1983 o tema da transferência dos direitos de construção ficaria em suspenso, voltando a surgir somente em 1984, quando, então, é aprovada a transferência através da Lei ํำ.725. Sua promulgação foi uma tentativa de proteger os imóveis de interesse histórico e compensar os proprietários privados, que se sentiam prejudicados pela obrigatoriedade da preservação instituída pelo tombamento e, como forma de oposição ao ato, promoviam ações que iam contra a salvaguarda do bem cultural (JOSÉ, 2009).

A iniciativa do poder público ao promulgar a lei aconteceu após um evento traumático ocorrido, em 1982. O vazamento de uma listagem contendo a relação de imóveis, na Avenida Paulista, que viriam a ser objetos de tombamento pelo CONDEPHAAT ${ }^{124}$, provocou, como reação, a demolição imediata de vários casarões. Esta área, extremamente valorizada, e pela qual já se previa a passagem do metrô

124 O Conselho de Defesa do Patrimônio Histórico, Arqueológico, Artístico e Turístico (CONDEPHAAT) foi instituído pela Lei Estadual 10.247 de 22 de outubro de 1968. (SÃO PAULO, 1968) 
era de grande interesse imobiliário para incorporadoras e construtoras. Antecipandose ao comunicado da notificação de tombamento, os imóveis foram demolidos a pedido de seus proprietários, que eram contra a preservação, pois esta congelaria seus bens e reduziria o valor destes no mercado imobiliário (MARIUZZO, 2005).

Apesar das reações às demolições terem sido imediatas, com o Conselho deliberativo do CONDEPHAAT pedindo sua demissão coletiva, somente seria tomada uma medida em 1984, ano em que foi elaborado pela Secretaria Municipal de Planejamento (SEMPLA) um Projeto de Lei ${ }^{125}$ recomendando a comercialização do potencial construtivo não utilizado de imóveis preservados por lei municipal. Aprovado em junho do mesmo ano, este originou Lei nº 9.725/1984 que dispunha sobre a Transferência de Potencial Construtivo ${ }^{126}$ não utilizado por imóveis preservados e sua cessão para outros imóveis situados no perímetro de uso circundante ao imóvel salvaguardado. E, apesar de toda comoção gerada com as demolições, a lei não contemplou os imóveis protegidos por tombamento, ou seja, aqueles salvaguardados a nível estadual pelo CONDEPHAAT (SÃO PAULO, 1984).

O instrumento foi formatado para viabilizar a transferência de $60 \%$ do potencial construtivo, cuja totalidade só seria permitida àqueles que se disponibilizassem a destinar o imóvel para instalação de atividades que possibilitassem a fruição pública, desde que permitidas pela Lei de Zoneamento mediante pedido do proprietário. $\mathrm{O}$ potencial seria calculado considerando o coeficiente máximo de aproveitamento da zona de uso contígua mais permissiva, podendo ser transferido no todo ou em parcelas, para um ou mais lotes.

A transferência poderia ser realizada nas zonas Z2, Z3, Z4, Z5, Z8, Z11, Z12 e $\mathrm{Z}_{13^{127}}$. Contudo, na zona de uso Z2, zona residencial de baixa densidade, situada nas áreas de maior renda, a transferência só poderia ser efetuada para lotes que se encontrassem num entorno considerando um raio de até $1.000 \mathrm{~m}$ do imóvel Z8.200 em questão. Já nas zonas de uso predominantemente residencial como Z1, Z9 e Z14,

\footnotetext{
125 SÃO PAULO (cidade). Projeto de lei 0087/84. São Paulo, 1984

${ }^{126}$ Entendemos que esta é a primeira vez que a transferência de direitos de construção passa a se chamar Transferência de Potencial Construtivo.

127 Além destas zonas a transferência também poderia ser realizada aos imóveis residenciais preservados, desde que localizados nas zonas de uso Z1, Z9, Z14, Z15, Z16, Z17 e Z18. A Lei no 7.805, de 01 novembro de 1972 dispôs sobre o parcelamento, uso e ocupação do solo do Município de São Paulo (SÃO PAULO, 1972)
} 
seria concedida, também, a isenção de Imposto Territorial e Predial Urbano (IPTU) mediante solicitação do proprietário, sem limite de tempo previsto para concessão desde que fosse mantido o uso residencial ${ }^{128}$ (SÃO PAULO, 1984).

No entanto, apesar da lei 9.725/84 visar a um maior comprometimento dos agentes privados na preservação dos imóveis, esta mobilização não chegou a se efetivar. Por um lado, porque as áreas lindeiras à Z8-200 já possuíam um alto coeficiente de aproveitamento do solo, não despertando assim o interesse pela aquisição. E por outro porque, comparativamente, outros instrumentos que seriam lançados nos anos seguintes (como as Operações Interligadas) seriam muito mais atrativos para o capital imobiliário que, desinteressado pela região central, desejava a flexibilização da legislação urbanística em outras áreas da cidade (JOSÉ, 2009. p. 60).

Com intuito de minimizar os gastos públicos, a gestão Mário Covas (1982-1985) em sua proposta de Plano Diretor, recomendava a utilização da parceria públicoprivada. O procedimento se daria através de um instrumento urbanístico denominado Operação Urbana ${ }^{129}$, que teria dentre seus objetivos a viabilização de equipamentos urbanísticos, infraestrutura e produção de habitação social, assim como acelerar as transformações urbanísticas tanto nos bairros periféricos quantos nas áreas centrais do município de São Paulo (MARICATO; WHITAKER, 2002 apud NOBRE, 2004).

As Operações Urbanas se constituem como um conjunto de intervenções coordenadas no solo urbano, devendo contar com a participação da população na tomada de decisões ${ }^{130}$. Estas são implementadas e operacionalizadas pela administração pública, em conjunto com agentes do setor privado, em um perímetro delimitado da cidade. Configuram-se, portanto, como um plano de caráter urbanístico com aplicação restrita e um setor do município devendo ser proposta por este pois, conforme a Constituição Federal de 1988, é obrigação das unidades da federação a ordenação do solo (BRASIL, 1988; BRASIL, 2001).

Regulamentadas a nível nacional pelo Estatuto da Cidade, em $2001^{131}$, marco legal das políticas públicas, como Operações Urbanas Consorciadas estas já eram

\footnotetext{
${ }^{128}$ Foi realizado somente um caso de transferência e este deu-se em lotes do mesmo proprietário, a Casa das Rosas, na Avenida Paulista. (EMURB, 1989)

129 Plano Diretor 1985 - 2000. (SEMPLA, 1985)

130 Este item somente foi inserido quando da aprovação do Estatuto da Cidade, em 2001. (BRASIL, 2001)

131 Lei $n^{0}$ 10.257, de 10 de julho de 2001. (BRASIL, 2001)
} 
utilizadas na cidade de São Paulo, desde 1991. As Operações Urbanas foram instituídas pela primeira vez no Plano Diretor proposto pela gestão Mário Covas, e tinham como base a ZAC francesa, porém só foram implementadas com o estabelecimento das Operações Interligadas, em 1986 (SEMPLA, 1985; MALERONKA, 2010; MONTADON, 2009).

Na gestão de Jânio Quadros (1985-1989), as Operações Urbanas foram engavetadas em detrimento de uma nova proposta de instrumento: a Operação Interligada, instituída através da Lei n-10.209/86, e conhecida por Lei de "Desfavelamento", esta concedia aos proprietários de terras ocupadas por favelas a oportunidade de doar a prefeitura um certo número de habitações de interesse social em troca de modificações nos índices urbanísticos e categorias de uso nos terrenos de sua propriedade. O mecanismo foi suspenso em 1998 por estar em desacordo com a Lei de Zoneamento segundo o Ministério Público e, em 2000 foi proibido devido sua inconstitucionalidade (NOBRE, 2004; SÃO PAULO, 1986).

Em 1988, foi aprovado um Plano Diretor ${ }^{132}$ que estabeleceu diretrizes gerais para a cidade e incorporou as Operações Interligadas e as Operações Urbanas que, diante da falta de recursos públicos para realizar as obras para o centro de São Paulo surgiu como uma alternativa. Nasce, assim, a Operação Urbana Anhangabaú133, adotada com o objetivo de conceder benefícios urbanísticos em troca de contrapartida financeira, resgatando a proposta realizada na gestão Mário Covas e se assemelhando as Operações Interligadas, o instrumento surgiu com objetivo de atrair o interesse de investidores privados na área central da cidade (JOSÉ, 2009; SÃO PAULO, 1991).

\footnotetext{
132 Lei $n^{\circ} 10.676$, de 7 de novembro de 1988 (SÃO PAULO, 1988).

133 Lei no 11.090, de 16 de setembro de 1991. Estabelece programa de melhorias para a área de influência imediata do Vale do Anhangabaú, cria incentivos e dá outras providências (São Paulo, 1991).
} 


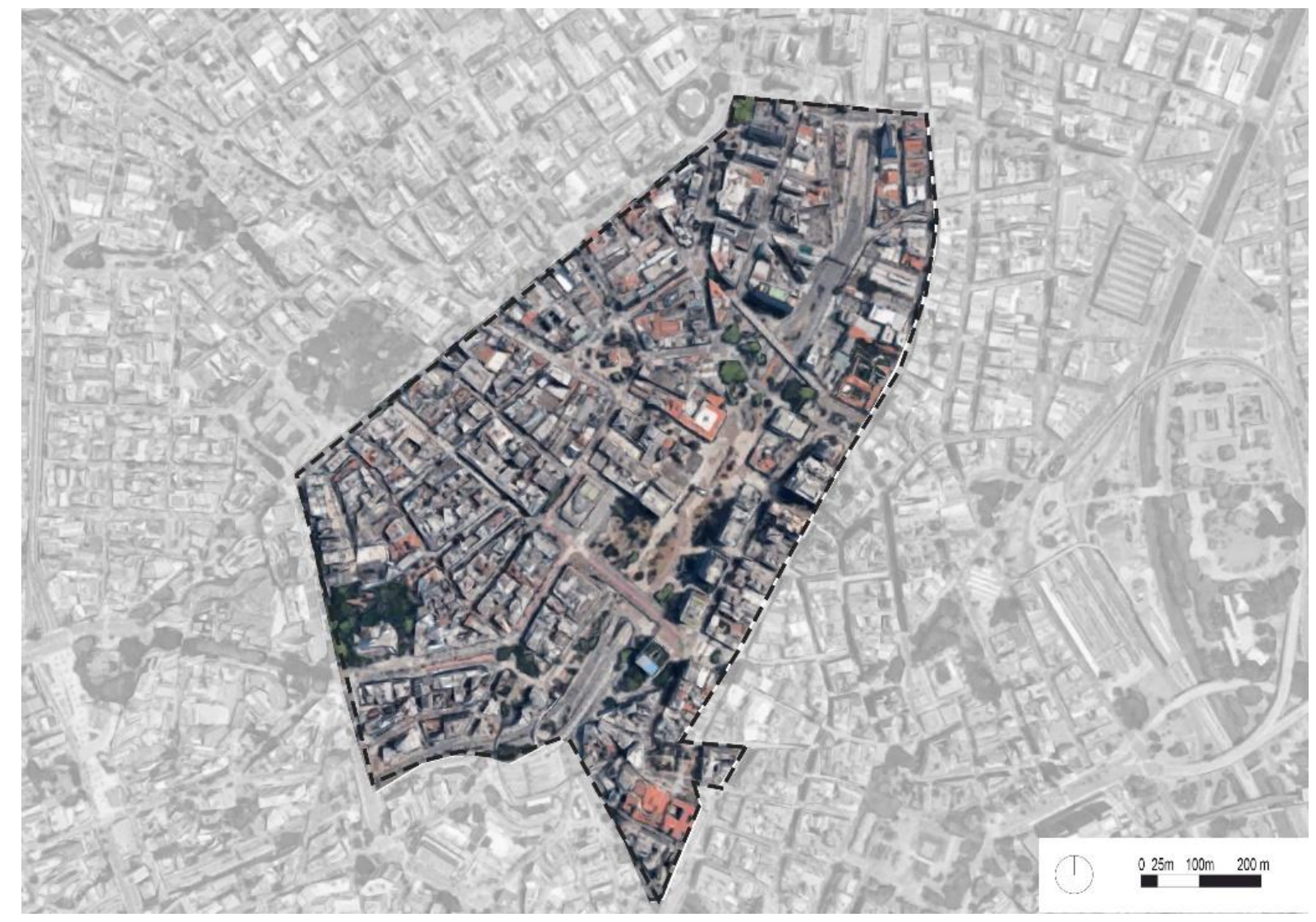

Figura 3.2 - Perímetro da Operação Urbana Anhangabaú. Modificações da autora sobre base Mapa Digital da Cidade. Fonte: Plano Diretor de São Paulo, 2014.

O mecanismo básico para obtenção de recursos na Operação Urbana Anhangabaú era o mesmo utilizado nas Operações Interligadas, ou seja, a venda de direitos de construção que possibilitavam a ultrapassagem dos limites estabelecidos pela Lei de Zoneamento. A diferença se concentrava em sua aplicação que, ao invés de serem utilizados exclusivamente em habitações de interesse social, como ocorria nas Interligadas, eles seriam destinados a obras e serviços necessários dentro da área definida para a Operação. E, contrariamente as Operações Interligadas que poderiam ser implementadas nos quatro quadrantes da cidade, a Operação Urbana era objeto de um perímetro onde seriam gerados e aplicados os recursos (LEFÉVRE, 1990).

A Operação Urbana Anhangabaú se enquadrava numa política de revalorização da área central de São Paulo. Contando com um conjunto coordenado de ações, objetivava a recuperação ambiental e da paisagem urbana, a preservação dos edifícios de valor histórico e artístico, e a melhoria das condições de acesso tanto para seus moradores quanto para os usuários da região. Foram instituídos quatro 
instrumentos visando complementar as obras de reurbanização do Vale do Anhangabaú: implementar um programa de melhorias composto pelo remanejamento de ruas, o restauro e implantação de esculturas, o estabelecimento de calçadões e bulevares, a manutenção dos equipamentos urbanos e a macrodrenagem do Vale do Anhangabaú (CASTRO, 2007; SÃO PAULO, 1991).

A disponibilização dos instrumentos objetiva atrair o interesse dos investidores privados. O primeiro permitia exceções à legislação de uso e ocupação do solo, nos moldes das Operações Interligadas, desde que fosse realizada contrapartida financeira. Já a regularização de construções, reformas e ampliações, seria permitida contanto que fosse realizada uma contrapartida correspondente a $200 \%$ do benefício concedido. Como terceiro mecanismo, foi disponibilizada a Transferência de Potencial Construtivo dos imóveis listados como Z8-200, tombados e que viessem a ser tombados ${ }^{134}$. E, procurando aumentar e organizar o espaço para pedestres, bem como promover a abertura de espaços e passagens no interior das quadras foi concedida a cessão onerosa do espaço aéreo e subterrâneo, cuja contrapartida financeira seria definida caso a caso (SÃO PAULO, 1991).

Pelo caráter de proposição primário, foram estabelecidos alguns limites para realização da Operação, como, o período de vigência de três anos e o total de área construída de acréscimo a ser negociada, fixado em $150.000 \mathrm{~m}^{2}$, num perímetro de $841.600 \mathrm{~m}^{2}$, considerado aceitável em termos de sobrecarga à infraestrutura existente. A fixação de uma quantidade de área a ser negociada, recaia, também, no fato do centro de São Paulo ser uma região já urbanizada e, principalmente, por conter edifícios históricos que eram protegidos legalmente ${ }^{135}$. E, para contribuir na preservação destes edifícios a Operação Urbana Anhangabaú disponibilizava o mecanismo da Transferência de Potencial Construtivo não utilizável das construções, considerando um coeficiente de aproveitamento de seis vezes a área do terreno. 0 potencial construtivo seria obtido pela diferença entre o potencial construtivo do lote e a área construída nele existente. A transferência seria autorizada desde que o

\footnotetext{
134 Não eram permitidas transferências para imóveis situados em Z1, Z9, Z14, Z15, Z16, Z8-100 e nos corredores de uso especial Z8-CR1, Z8-CR2, Z8-CR4 quando lindeiros a Z1, Z8-CR5 e Z8-CR4. As áreas de mananciais protegidas por lei também não eram passíveis de receber transferência de potencial construtivo (SÃO PAULO, 1991).

${ }^{135} \mathrm{Em} 1992$ foram tombados muitos imóveis na área central de São Paulo através da Resolução 37/CONPRESP/1992 (CONPRESP, 1992).
} 
potencial adquirido não elevasse em mais de $50 \%$ o coeficiente de aproveitamento da quadra em que se situava o imóvel (JOSÉ, 2009; SÃO PAULO, 1991).

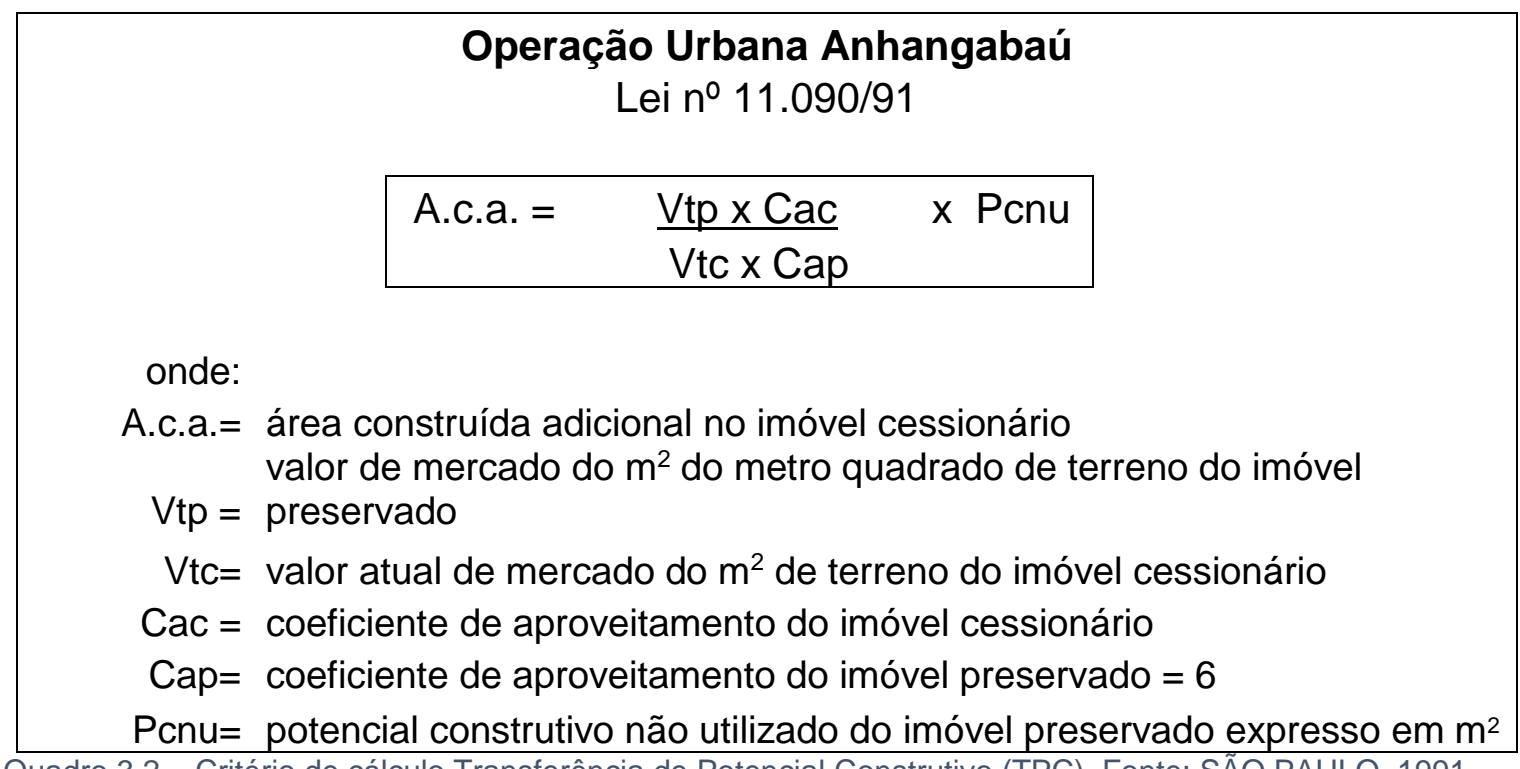
Quadro 3.2 - Critério de cálculo Transferência de Potencial Construtivo (TPC). Fonte: SÃO PAULO, 1991.

A equivalência de valores, e não de áreas, foi o método escolhido na efetivação da Transferência de Potencial Construtivo (TPC) possivelmente por este aumentar a atratividade para os investidores imobiliários (CASTRO, 2007). Parte do diferencial do valor recebido na transação do potencial seria obrigatoriamente destinado à conservação e restauração do imóvel, cujo projeto deveria obedecer diretrizes definidas pelo Grupo Técnico de Trabalho ${ }^{136}$ (GTT) e posteriormente ser submetido à aprovação da SMC e, também, da Secretaria Municipal do Planejamento (SEMPLA) nos casos das zonas de uso Z8-200.

É interessante pontuar que, nas formulações do projeto de lei, na sexta versão do projeto mais especificamente, dois grupos tinham propostas diferentes quanto a implementação da TPC e um dos pontos objeto de divergência ia de encontro ao fato da transferência poder ser realizada em outras áreas da cidade. Um dos grupos defendia a necessidade de manter a transferência somente para Z5-002, excetuandose o perímetro da operação, pois fora desta área a transferência poderia intervir na densidade bem como provocar a especulação imobiliária devido à diferença de valores do $\mathrm{m}^{2}$ de área construída. Contudo, apesar de terem adotado a proposta 
contrária, que visava a TPC para toda a cidade e utilizava a equivalência de valores para o cálculo, a operação não obteve sucesso (EMURB, 1989).

Apesar do Projeto de Lei e, da Lei propriamente dita, da Operação Urbana Anhangabaú sempre pontuarem a questão da preservação do patrimônio histórico como um dos principais objetivos da operação, não encontramos resultados que possam confirmar o sucesso deste objetivo. Alguns imóveis foram restaurados e conservados sim, temos como exemplo o Theatro Municipal de São Paulo, a Casa da Marquesa de Santos, entre outros; porém as obras não foram realizadas com a transferência de potencial construtivo, pois estes eram imóveis públicos ${ }^{137}$. No que se refere aos imóveis privados, que eram o objeto da aplicação do instrumento, não foram realizadas propostas para obtenção da transferência. Considerando $\mathrm{O}^{\mathrm{CA}^{138}}=4$ estipulado pela legislação em casos de imóveis residenciais e o CA $=6$ proposto para edifícios comerciais, a proposta de adotar um coeficiente igual a seis para os imóveis preservados não se mostrou instigadora o suficiente para provocar uma demanda pela TPC.

\subsection{A Transferência de Potencial Construtivo na Operação Urbana Centro}

A Operação Urbana Anhangabaú foi encerrada em 1994, com resultados inexpressivos em relação às expectativas formuladas em seus objetivos (SÃO PAULO, 1991). A necessidade de formulação da Operação Urbana teria surgido da constatação da existência de uma demanda por investimentos na área central que não eram passíveis de serem realizados devido às restrições da Lei de Zoneamento. Contudo, durante seus três anos de vigência somente sete propostas de participação na operação foram encaminhadas (LEFÉVRE, 2018).

No entanto, a Operação Urbana Anhangabaú serviu para consolidar uma visão a respeito do problema da área central e, com isso, ficou evidente a necessidade de

137 A Operação Urbana Anhangabaú não obteve sucesso e os recursos arrecadados não foram aplicados nas obras do Vale, que foi realizada com recursos a fundo perdido pela Prefeitura (JOSÉ, 2009).

138 Coeficiente de Aproveitamento é a relação entre a área edificada, excluída a área não computável, e a área do lote. Disponível em: http://gestaourbana.prefeitura.sp.gov.br Acessado em: 22.dez.2017 
se ter uma ação mais abrangente e voltada para esta área, que criasse condições de atratividade para a recuperação de seu status e imagem. Nesse escopo, surge a Associação Viva o Centro (AVC) ${ }^{139}$, concebida por um grupo de empresários do setor financeiro que se colocou como o principal agente articulador nas questões referentes a formulação de políticas para área central (JOSÉ, 2009).

A associação tinha um caráter explicitamente voltado a atender os interesses dos proprietários privados e a ideia de sua criação teve como modelo as "Associações de Proprietários Urbanos" norte-americanos. Cujos trabalhos se pautavam em reverter à situação de declínio e abandono nas áreas que estavam sofrendo processos de deterioração pela evasão de instituições de grande significação econômica e institucional (JOSÉ, 2009). Sendo assim, a AVC tinha como objetivo revalorizar a área central da cidade, através de participação ativa nas ações referentes à região buscando se constituir como interlocutor junto ao poder público.

Em 1993, foi instituído para o centro de São Paulo um Programa de Requalificação Urbana e Funcional (ProCentro) ${ }^{140}$, com papel ativo da Associação Viva o Centro, através de seu corpo técnico que, em parceria com uma equipe Inter secretarial da administração municipal, cooperou na elaboração de uma série de propostas e decretos para a área central do município dando origem assim ao ProCentro ${ }^{141}$. Um dos principais resultados do ProCentro foi a criação da Lei de Fachadas, que tinha como objetivo fornecer, entre outros, incentivos fiscais para viabilizar o restauro de fachadas no Centro através da isenção do IPTU para os imóveis protegidos ${ }^{142}$. A AVC defendia a criação de um instrumento semelhante à Operação Urbana Anhangabaú para ser aplicado em uma área maior do Centro, e com seu desempenho significativo na concepção do ProCentro, estes puderam

\footnotetext{
139 Reunindo representantes das empresas sediadas na área central a associação Viva o Centro foi criada em 1991 (JOSÉ, 2009).

140 O Decreto oㅜ 33.390 de 14 de julho de 1993 cria a comissão ProCentro para atuar no Programa de Requalificação Urbana e Funcional do Centro de São Paulo. Instituído após quase dois anos de vigência da Operação Urbana Anhangabaú este propunha diretrizes para a implantação de uma nova Operação Urbana. (SÃO PAULO, 1993)

${ }_{141}$ Através da Comissão Executiva do ProCentro.

142 A Isenção de IPTU não excluía a possibilidade da obtenção da Transferência de Potencial Construtivo, mesmo assim não obteve resultados relevantes ao longo dos anos. SÃO PAULO (cidade). Lei ํo 12.350 de 6 de junho de 1997. Concede incentivo fiscal aos proprietários de imóveis ou aos patrocinadores das obras de recuperação externa e conservação de imóveis localizados na Área Especial de Intervenção, objeto do Programa de Requalificação Urbana e Funcional do Centro de São Paulo - PROCENTRO, ou outro equivalente que venha a ser implantado, e dá outras providências. (São Paulo, 1997).
} 
delinear a elaboração de uma proposta de projeto para a área central que, posteriormente, viria a ser absorvida na Operação Urbana Centro (OUC) (SÃO PAULO, 1993).

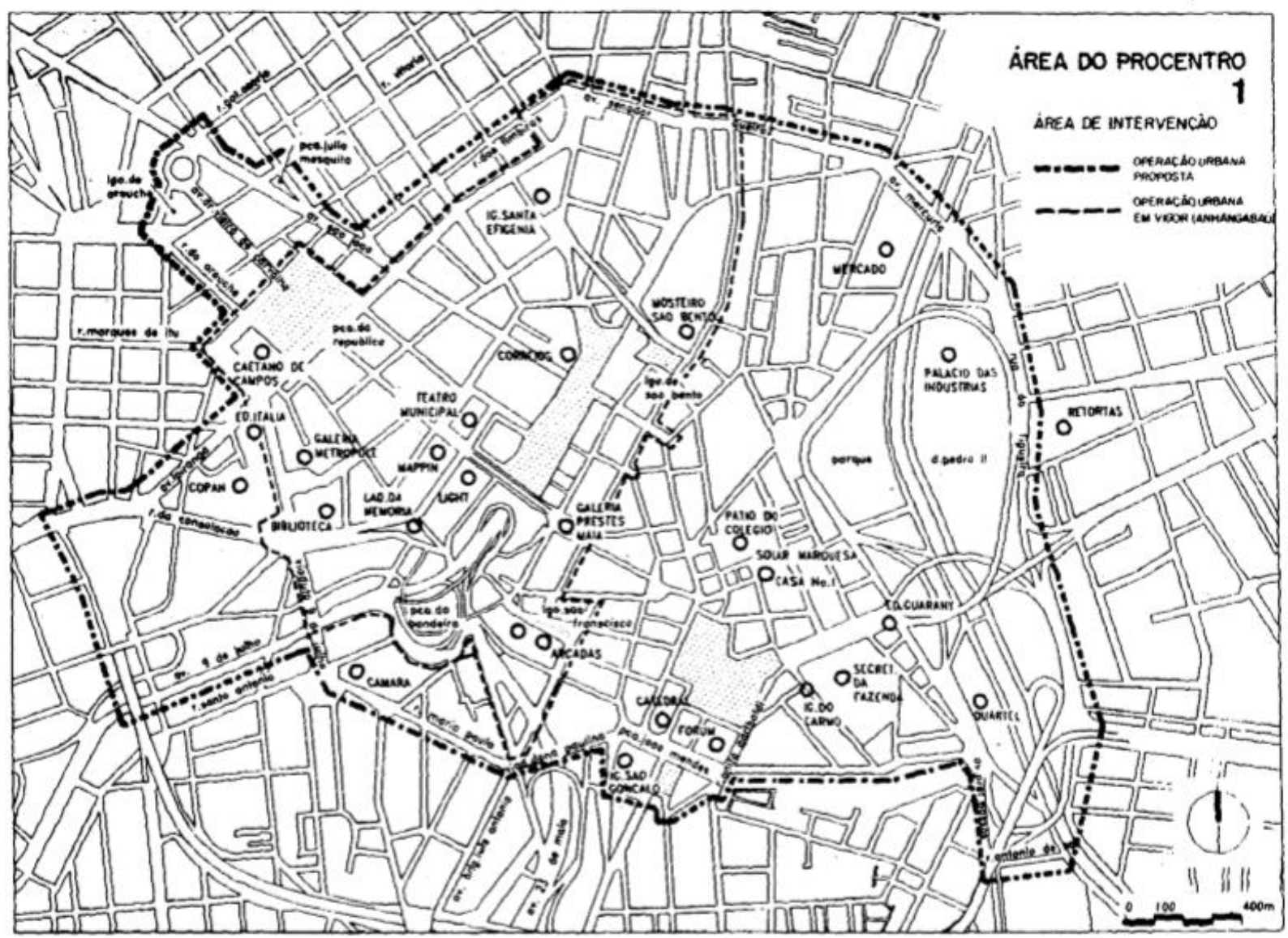

Figura 3.3 - Perímetro do ProCentro. Fonte: DOM, 1993.

Após exame do Projeto de Lei da Operação Urbana Centro pudemos apreender que esta foi formulada partindo da experiência da Operação Urbana Anhangabaú e do ProCentro. Por meio da proposição de um perímetro que alcance um maior número de imóveis e áreas, almeja-se uma participação superior de proprietários de imóveis e de empreendedores imobiliários, visando um retorno "não apenas financeiro, mas também de retomada da Área Central para a realização de novos empreendimentos" (SÃO PAULO, 1993, p. 901).

Assim, em 1997, a Operação Urbana Centro foi aprovada tendo como objetivo focal a implementação de condições que reforçassem a importância da área central para a metrópole de São Paulo, "tornando-a atraente para investimentos imobiliários, 
turísticos e culturais e preparando-a para o papel de cidade mundial ${ }^{143 " ~(E M U R B, ~}$ 1997, p. 1). Abrangendo uma extensão de aproximadamente 662,9ha, alcança as áreas do Glicério, Brás, Bexiga, Vila Buarque e Santa Efigênia, cujo perímetro é composto por uma heterogeneidade de usos e densidades.

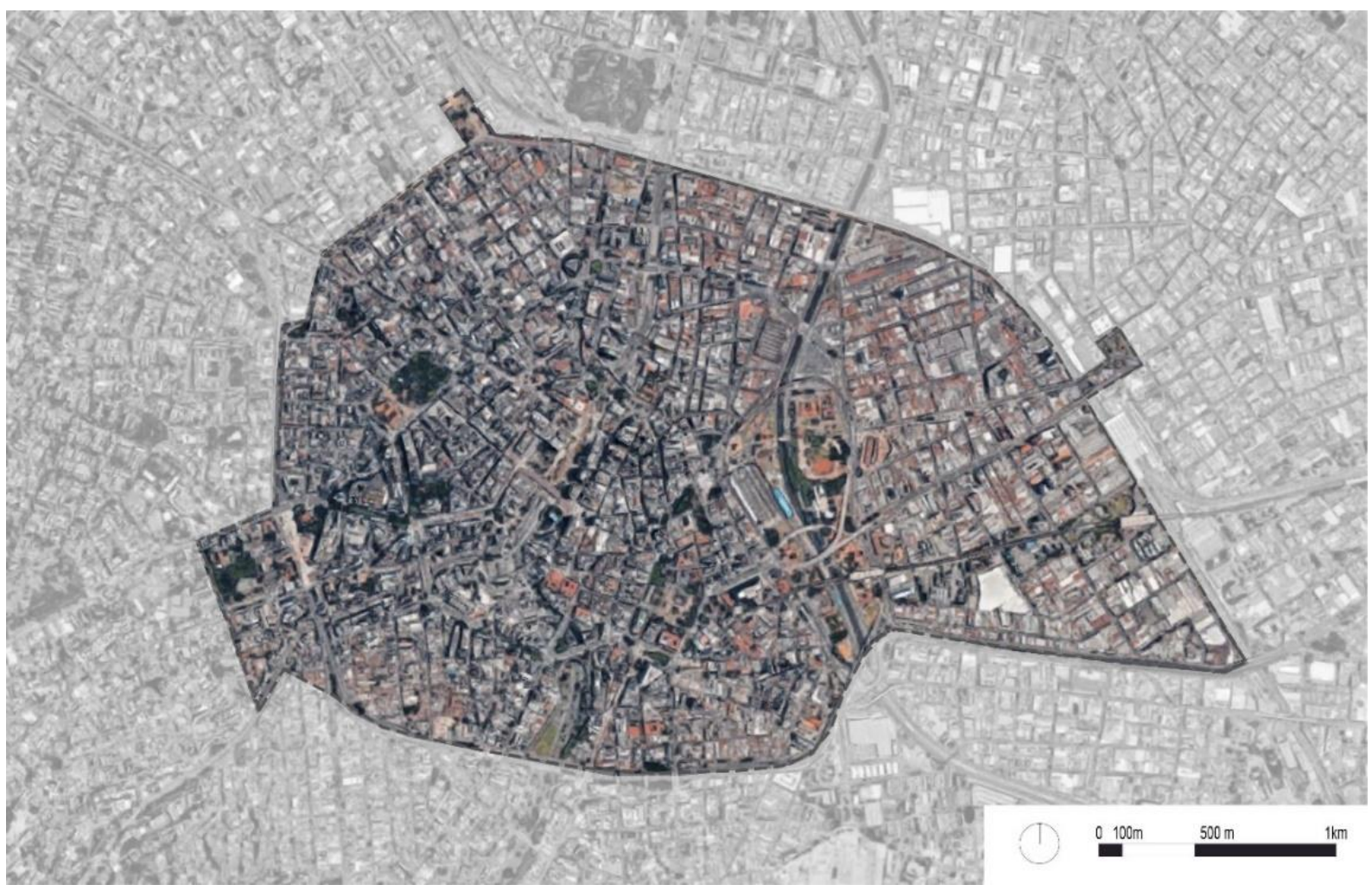

Figura 3.4 - Perímetro da Operação Urbana Centro. Elaboração da autora. Fonte: Mapa Digital da Cidade com camadas obtidas a partir do GEOSAMPA, 2017.

Abrangendo entre suas diretrizes o estímulo ao remembramento de lotes, a ampliação e recuperação de espaços públicos, o incentivo à construção de habitações, a intensificação do uso do solo, a conservação e restauro dos edifícios de interesse histórico bem como sua valorização através da (re)composição de faces, apreendemos que a Operação Urbana Centro espera promover estas transformações através de incentivos urbanísticos visto que esta não abarcou o programa de melhorias de obras proposto em seu Projeto de Lei (SÃO PAULO, 1993; SÃO PAULO, 1997; MONTANDON, 2009).

143 Em 1994 foi promovido um encontro pela Associação Viva o Centro reunindo profissionais de diversas áreas a fim de discutir temas relativos ao Centro de São Paulo. Este contou também com a presença de Jordi Borja, um dos urbanistas responsáveis pelo processo de renovação urbana de Barcelona, o qual colocou a importância de investimento no Centro num contexto global, onde as cidades deveriam apostar nas suas diferenças para que se tornassem competitivas, pois o que distinguia uma de outra era o seu Centro (AVC, 1994). 
Durante os três primeiros anos da OUC, foi definida uma Área de Especial Interesse (AEI), conforme Figura 3.6, onde era concedida isenção de contrapartida para os imóveis localizados no perímetro, já os imóveis que se encontravam fora da Área de Especial Interesse (AEI), além de ficarem dispensados da contrapartida financeira, estes contavam ainda com a oferta de um Coeficiente de Aproveitamento diferenciado: 12 (doze) para imóveis residenciais, 6 (seis) para imóveis corporativos e 9 (nove) para categoria hotéis de turismo. Coincidentemente, a AEl é a área com maior incidência de imóveis protegidos e, neste período, foram efetuadas 13 das 37 propostas $^{144}$ realizadas até hoje para Transferência de Potencial Construtivo, estando nesta área três das seis que tiveram seu processo aprovado e concluído, ou seja, poderiam realizar as exceções à lei, sem pagar a contrapartida (SÃO PAULO, 1997; DEUSO, 2016).

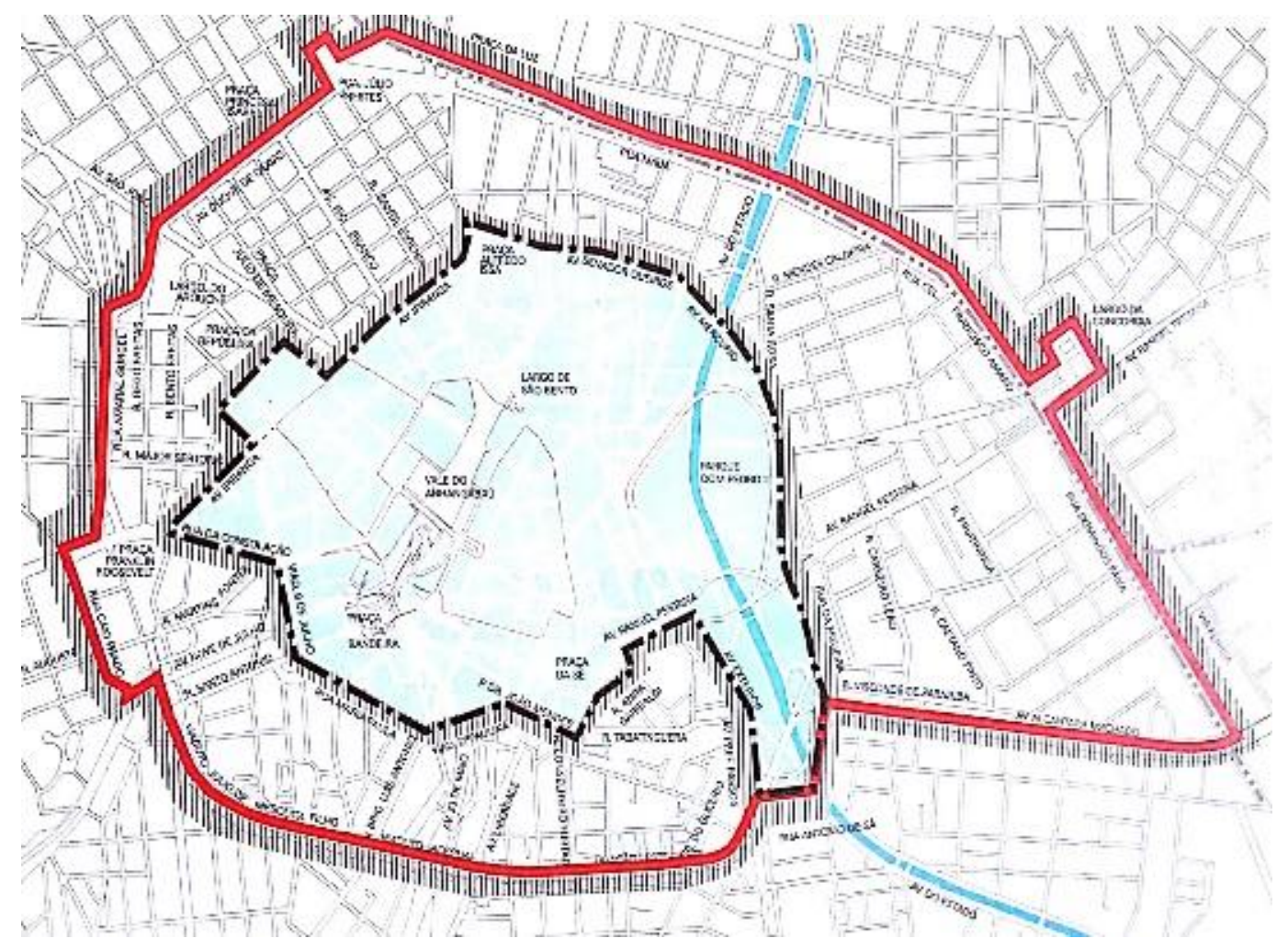

Figura 3.5 - Delimitação da Área de Interesse Especial, delimitada por traço preto, na Operação Urbana Centro. Fonte: Cartilha da Área Central (EMURB, 1997).

144 Conforme planilha de controle da Transferência de Potencial Construtivo disponibilizada pelo Departamento de Uso do Solo (DEUSO) em 2017. 


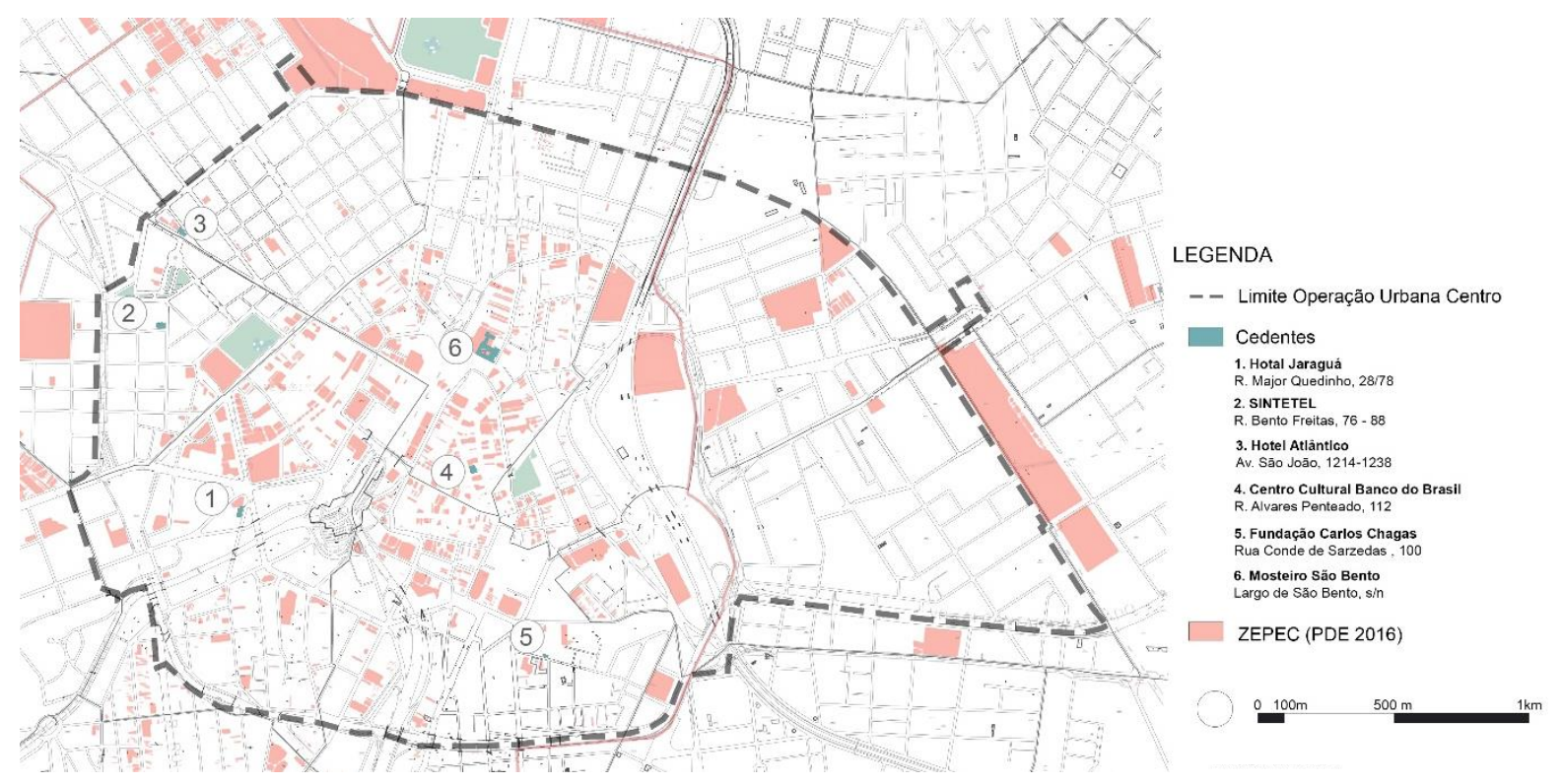

Figura 3.6 - Localização dos imóveis que realizaram a transferência. Fonte: Mapa elaboração da autora sobre base Mapa Digital da cidade de São Paulo e sobre dos disponibilizados no Diário Oficial do Município. Fonte: SÃO PAULO, 2014; DOM, 1998 A 2017.

A Lei 12.349, de 6 de junho de 1997, propõe uma série de benefícios que se configuram como exceção a Lei de Zoneamento vigente, aplicáveis mediante contrapartida financeira, "modificações de índices urbanísticos, de características de uso e ocupação do solo e de disposições do Código de Obras e Edificações; regularização de construções, reformas ou ampliações executadas em desacordo com a legislação vigente desde que fossem concluídas até a data de aprovação da lei; cessão onerosa de espaço público e; a transferência do potencial construtivo de imóveis tombados (SÃO PAULO, 1997a, art. 4º). A lei também instituiu a adoção de coeficiente máximo igual a seis para imóveis de uso residencial, uso misto (residencial com estacionamento) e hotéis (SÃO PAULO, 1997a, art. 3ํ).

Analisando o mapa de zonas de uso e ocupação do solo, conforme figura 3.7, vigente a época da aprovação da Operação Urbana podemos observar que nas zonas Z3, Z4 e Z5, ou seja, maior parte do perímetro proposto, o coeficiente máximo poderia chegar a quatro. A zona de uso Z5, região onde se encontra maior número de imóveis tombados e para os quais foi disponibilizado o incentivo da Transferência de Potencial Construtivo, cujo mecanismo iremos tratar mais adiante, o coeficiente adotado é o efetivo, significando, assim, que nem a proposição de CA igual a 6 (seis) da OUC ou $\mathrm{CA}$ igual 4 (quatro) do zoneamento se aplicam, mas sim aquele já que existente no lote (EMURB, 1997). 


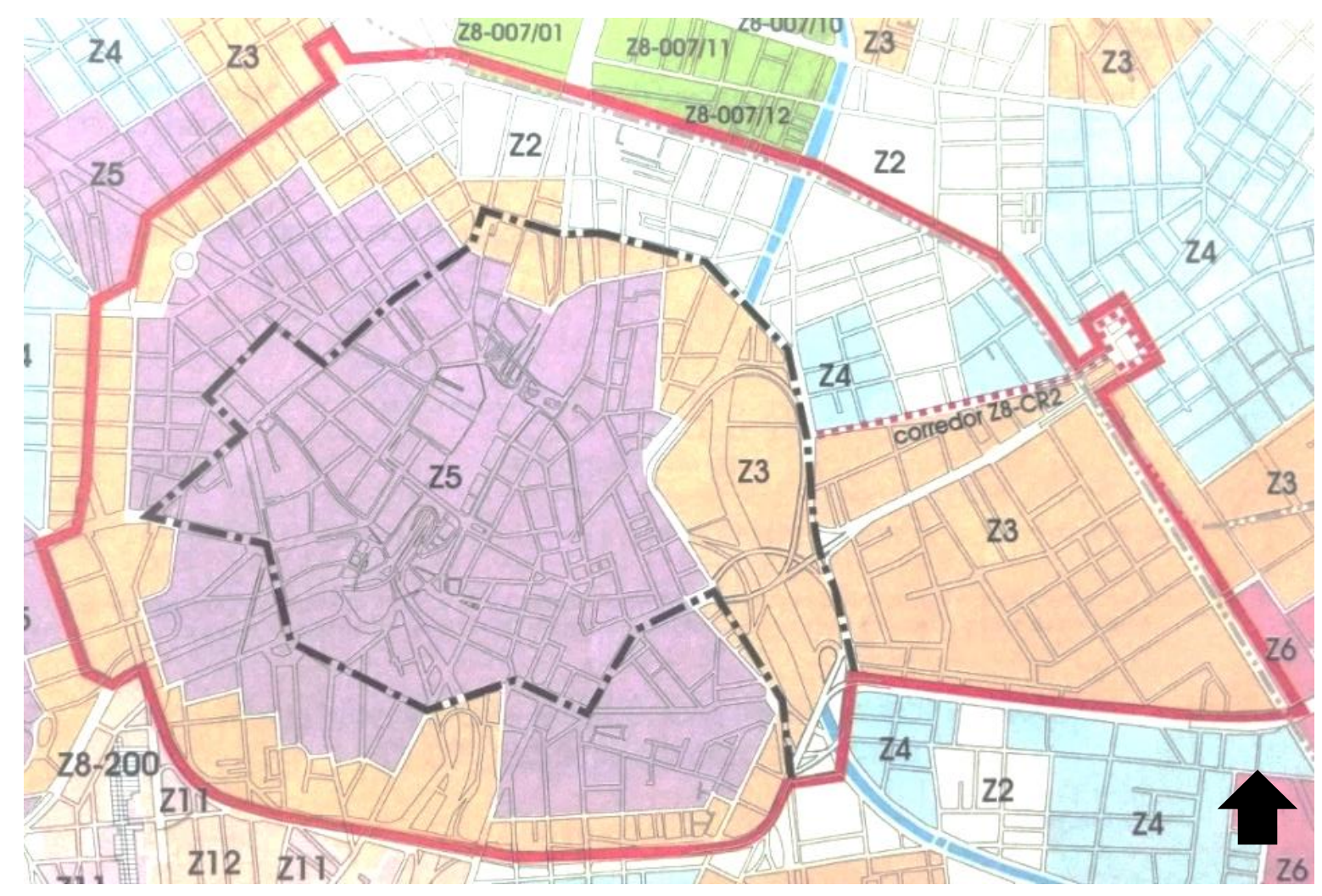

Figura 3.7 - Zonas de uso e ocupação do solo na área da Operação Urbana Centro. Fonte: A Cartilha da Área Central (EMURB, 1997).

A gestão da Operação Urbana era realizada inicialmente pela EMURB, atualmente SP-Urbanismo ${ }^{145}$, que seria nosso correspondente a uma sociedade de economia mista da $Z A C^{146}$ porém com funcionamento diverso mas que não iremos detalhar neste trabalho visto que não é nosso objetivo a analisar a OUC mas sim a Transferência de Potencial Construtivo. A SP-Urbanismo é responsável pelos recursos auferidos com as contrapartidas e conforme a lei da OUC deve empregá-los na execução de reformas e recuperações de edifícios contidos na área da operação e na restauração de imóveis tomabados desde que seja realizado um posterior ressarcimento pelo valor dispendido (EMURB, 1977).

A Operação Urbana Centro é composta, conforme designado por lei, por um Grupo Técnico e pela Comissão Executiva. A primeira etapa de análise deverá ser

145 A São Paulo Urbanismo - SP-Urbanismo é uma empresa pública que se originou da cisão da Empresa Municipal de Urbanização - EMURB, conforme Lei no 15.056, de 8 de dezembro de 2009 e Decreto o 51.415, de 16 de abril de 2010 (SÃO PAULO, 2009; SÃO PAULO, 2010.)

${ }^{146} \mathrm{~A}$ SP-Urbanismo é uma empresa pública significando com isso que a mesma foi instituída por lei e seu capital deve ser $100 \%$ público, atua com o objetivo de exploração de atividade econômica. Já uma sociedade de economia mista também é criada por lei, sendo constituída por capital público e privado, onde o capital público deve ser prevalente. Porém aceita a conjugação de recursos particulares com recursos provenientes de pessoas de Direito Público ou de entidades de suas Administrações indiretas (BRASIL, 2016). 
realizada pelo Grupo Técnico da operação, que é composto por representantes das secretarias que tem relação com a área central da cidade. Posteriormente, o processo é enviado a Comissão Executiva, formada por representantes eleitos entre os órgãos envolvidos, também de entidades civis, de empresas e de classe profissional, cuja competência recai na emissão de pareceres e na deliberação da proposta devendo seguidamente enviá-lo a Câmara Técnica de Legislação Urbanística (CTLU) que é a responsável por aprovar os projetos de Operação Urbana. A participação da população ocorre quando algum grande projeto proposto dentro do perímetro da operação vai à audiência pública, não temos como mensurar o quanto esta afeta na decisão final visto que não encontramos material nem dados referente ao assunto. $O$ único projeto a ser realizado na área da $\mathrm{OUC}^{147}$ e ao qual poderíamos ter tido oportunidade de participar da audiência, teve a mesma cancelada sem posterior remarcação (EMURB, 1977).

\section{Propostas solicitadas entre 1997 e 2015}

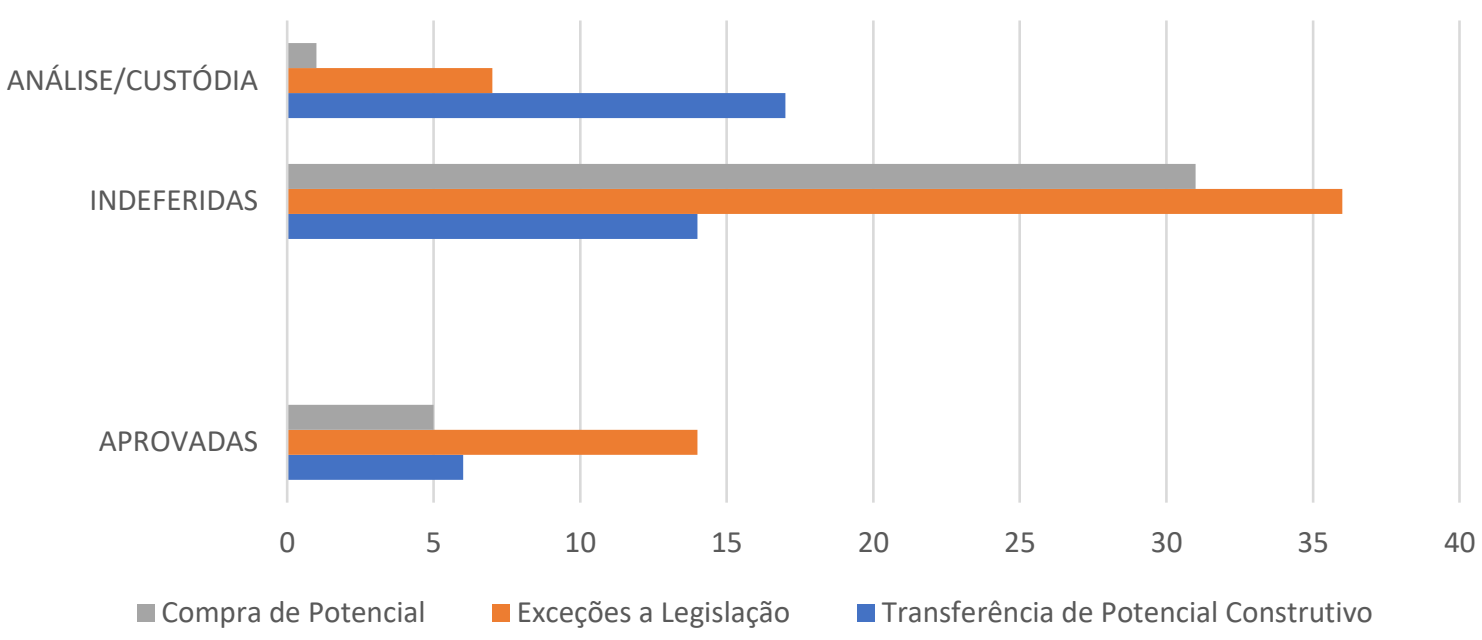

Figura 3.8 - Levantamento das solicitações de exceção à legislação no perímetro da Operação Urbana Centro Elaboração da autora. Fonte: SP-Urbanismo, 2017.

147 O projeto de requalificação urbana do Vale do Anhangabaú, no centro da cidade, realizado no ano de 2015 foi paralisado e não teve audiência pública, pois o espaço escolhido para a tal não comportava o número de participantes confirmados (ESTADO DE SÃO PAULO, 2015). 


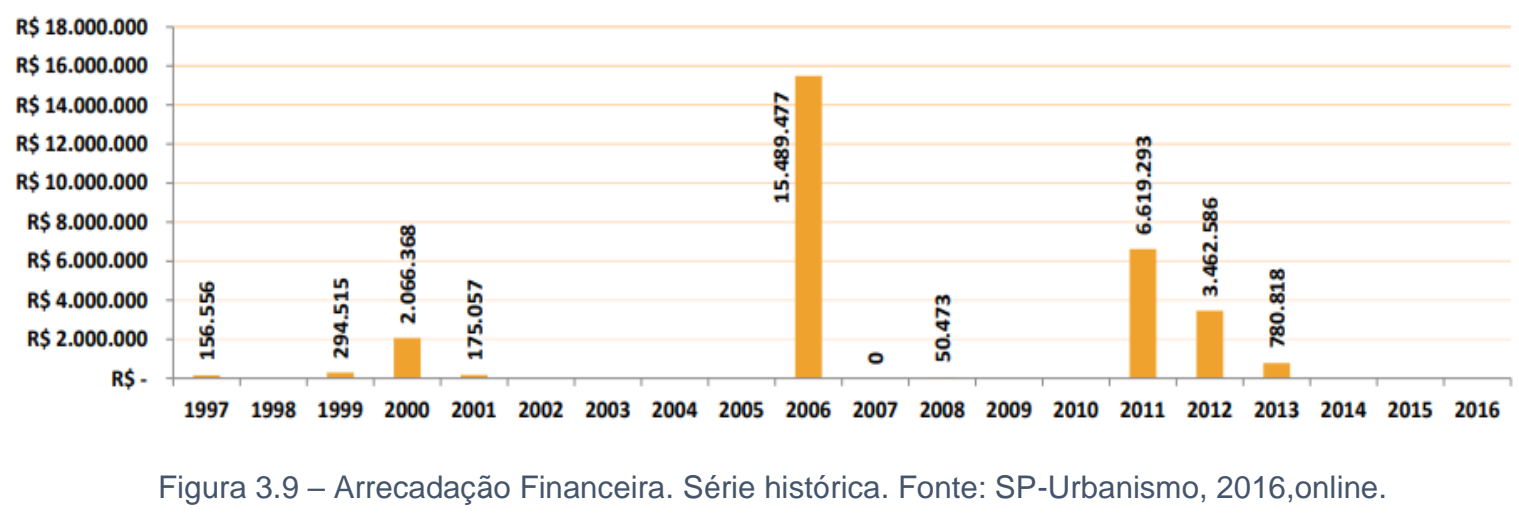

\begin{tabular}{|l|l|}
\hline \multicolumn{2}{|c|}{ QUADRO RESUMO 1997 - 2016} \\
\hline Intervenções concluídas & Intervenções em andamento \\
\hline Praça do Patriarca - pavimento e pórtico & Projeto Vale do Anhangabaú \\
\hline $\begin{array}{l}\text { Corredor cultural Xavier de Toledo - Praça D. } \\
\text { José Gaspar }\end{array}$ & Obras Rua do Gasômetro \\
\hline Termo de Referência - Censo Cortiços & Praça Roosevelt \\
\hline Desapropriações Nova Luz & Obras Praça das Artes \\
\hline \begin{tabular}{l} 
Projeto Reurbanização Parque D. Pedro \\
Quadro 3.3 - Obras realizadas no perímetro e com verbas da Operação Urbana Centro. Série histórica. \\
\hline
\end{tabular} & Execuçãa - Censo Cortiços \\
\hline
\end{tabular}

Através dos dados acima disponibilizados podemos verificar que, ao longo destes dezenove anos, a Operação Urbana Centro não obteve o êxito financeiro e urbanístico esperado quando de sua proposição, em 1997. Apesar da área central do perímetro da Operação se constituir como um centro histórico, onde um grande número de imóveis é protegido, o número de propostas aprovadas para Transferência de Potencial Construtivo ficou abaixo do esperado. Podemos observar uma elevação considerável na arrecadação financeira no ano 2006, e entendemos que isto se deveu aos reflexos da situação econômica que o país atravessava naquele período, quando o PIB de 2004 atingiu a maior alta em dez anos ${ }^{148}$. Contudo, nos anos posteriores não foram significativas as somas arrecadadas pela OUC. Quanto a realização de obras de restauro e valorização estas não foram objeto dos recursos auferidos pela operação, por mais que constem na legislação como um dos receptores dos recursos auferidos com as contrapartidas financeiras.

148 No ano 2004 o PIB brasileiro atingiu o percentual de 5,20\%. Fonte: FOLHA DE SÃO PAULO, 2005. 
Em 2001, foi realizado um relatório ${ }^{149}$ de avaliação da OUC que teve entre seus resultados a constatação da escassez de recursos obtidos pelo Poder Público em virtude dos benefícios concedidos, assim como a necessidade de revisão da Operação Urbana Centro para o atendimento das diretrizes referentes as leis: lei Federal ํㅜ10.257 de 2001 - Estatuto da Cidade e do Plano Diretor Estratégico, Lei noํ 13.430 de 2002 , que, porém, até o presente momento não foi efetuada. Em 2016, em virtude da aprovação do novo Plano Direitor ${ }^{150}$ e da Lei de Zoneamento, foram iniciados novos estudos de revisão para a Operação Urbana Centro. Estes constataram a necessidade de adequação das diretrizes à nova conformação da área central de São Paulo, da redefinição de incentivos, e do estabelecimento de um programa de intervenções visto que atualmente a OUC se compõe somente de diretrizes. A revisão da lei se faz premente considerando o período de atuação do instrumento e seu baixo retorno à municipalidade e à população, porém até a presente data a revisão não foi finalizada (EMURB, 2016).

A breve análise acima realizada das Operações Urbanas Anhangabaú e Centro teve como finalidade introduzir o tema da Transferência de Potencial Construtivo. E foi pelo mesmo motivo que redigimos o capítulo anterior, que neste caso, serviu de contraponto ao assunto neste ensaiado. Como foi dito anteriormente a Zone d'Amenagément Concerté, além de ter sido formulada pela mesma lei que instituiu o Plafond Légal de Densité, base para nossa TPC, serviu também como embasamento para a formulação das Operações Urbanas em São Paulo. Contudo, no rápido exame efetuado ao longo do Capítulo 2 desta dissertação, pudemos assimilar que, se na origem aquela serviu de base para as Operações Urbanas paulistanas o desenrolar foi, em muito, modificado.

Priemeiramente, pelo fato da ZAC não ser um instrumento formulado estritamente para contribuir na conservação e valorização dos bens de interesse histórico e culturais. Ttal fato, está colocado em lei, porém, na França existem outros instrumentos e programas para isso, como pudemos demonstrar com a análise do Secteur Sauvegardé e das ZPPAUP. Ela pode, sim, ser implementada em locais onde

\footnotetext{
149 Realizado por um Grupo de Trabalho instituído através da Portaria ํo113 - 08/ 05/ 2001.

150 O Plano Diretor Estratégico foi aprovado através da Lei no 16.050 de 2014. E a revisão da Legislação de Uso e Ocupação do Solo foi estabelecida pela Lei no 16.402 de 2016. (SÃO PAULO, 2014; SÃO PAULO, 2016)
} 
contenham alguns imóveis históricos porém não encontramos em nossa pesquisa material informando que a ZAC poderia ser implantada num área histórica, como é o caso da área central de São Paulo, pois para isso existe um dispositivo especificamente elaborado.

No que concerne a Operação Urbana Centro, esta se aproxima mais do Urban Renewal norte-americano por buscar relacionar os interesses de proprietários de imóveis em áreas históricas ao interesse do mercado imobiliário, utilizando o patrimônio histórico como chamariz. Afinal, mesmo nos E.U.A. existem programas e planos, como o anteriormente estudado Statewide Historic Preservation Plan, elaborados exclusivamente para fomentar a preservação e valorização de setores históricos, algo que falta no município de São Paulo e, no Brasil, neste momento.

Tomando como ponto de partida o Solo Criado e as Operações Urbanas, ao longo deste capítulo nos dispusemos a analisar o prelúdio da Transferência do Potencial Construtivo na cidade de São Paulo, que, como vimos, após anos de discussão sobre sua formulação se iniciou junto com a criação do Solo Criado o instrumento foi implantado na tentativa de beneficiar os proprietários de imóveis tombados em 1984. Este teve como um dos motivos para seu insucesso o alto coeficiente de aproveitamento dos imóveis lindeiros aos protegidos por lei.

Com a criação da Operação Urbana Anhangabaú, o instrumento da TPC retorna, mas agora como mecanismo vinculado a um instrumento e cujo objetivo seria a promoção da conservação do patrimônio de interesse histórico edificado na área central da cidade. Desta vez, estabelecendo um teto de coeficiente acima do já edificado, como forma de atrair o interesse dos investidores imobiliários e, autorizando a transferência somente de $60 \%$ do potencial construtivo do lote, salvo exceções. Ainda visando atrair os investidores imobiliários, em sua fórmula foi considerada a equivalência de valores e não de áreas, que trabalharia com a questão da densidade. Mesmo assim, mais uma vez não obteve resultado relevante, nenhuma proposta para obtenção da Transferência de Potencial Construtivo foi realizada.

Passados dois anos de implantação da Operação Urbana Anhangabaú, é proposto um novo projeto para a área central, cujo perímetro englobava aquele da Operação Urbana e tinha como incentivo para a preservação do patrimônio histórico a disponibilização de isenção fiscal, que poderia ser obtida em conjunto com a TPC, 
porém esta também não obteve uma adesão vultuosa. E, em 1997, com a aprovação da Operação Urbana Centro, a transferência de potencial construtivo retorna novamente como um dos mecanismos passíveis de propriciarem a exceção a Lei de Zoneamento vigente, neste caso, mais uma vez, buscando propriciar a conservação e o restauro dos imóveis tombados. No texto que se segue nos propomos a analisar e, se possível, avaliar os efeitos da TPC durante estes dezenove anos de sua implementação na área central de São Paulo. 
Capítulo IV - A TRANSFERÊNCIA DE POTENCIAL CONSTRUTIVO COMO INCENTIVO A PRESERVAÇÃO DO PATRIMÔNIO 


\subsection{A transferência de potencial construtivo na área central de São Paul}

Em 1991, seis meses antes da promulgação da Lei no 11.090/91, referente à Operação Urbana Anhangabaú (SÃO PAULO, 1991), foi aprovada no Conselho Municipal de Preservação do Patrimônio Histórico, Cultural e Ambiental da Cidade de São Paulo (CONPRESP) a abertura de tombamento ${ }^{151}$ do Parque Anhangabaú pela Resolução 06/91 ${ }^{152}$ (CONPRESP, 1991a), cobrindo um perímetro que coincidiu com aquele aprovado para a Operação Urbana. Considerando o valor histórico, social e urbanístico representado no espaço envoltório do Vale do Anhangabaú, em 1992, o processo foi finalizado e através dele foram tombadas ${ }^{153}$ duzentos e noventa e três edificações e nove logradouros públicos inseridos numa área um pouco maior que aquela estipulada em 1991.

Cumpre ressaltar que entre a abertura de tombamento e o tombamento em si, foi aprovada resolução intermediária descrevendo por listagem os imóveis a serem objetos de tombamento e, também, informando que "o estudo de preservação da área compatibilizaria os projetos e programas de obras já previstos pelo Poder Público Municipal" (art. $2^{\circ}$ ) bem como seria acolhido o amparo legal dos imóveis com alvarás de obras expedidos até 9 de abril de 1991, nas contestações do ato que instituiu a abertura de tombamento (art. $\left.3^{\circ}\right)^{154}$, claramente demonstrando um acordo posterior com o órgão responsável pela realização de projeto e planos em São Paulo, mais especificamente, se moldando a aplicação da Operação Urbana Anhangabaú (SÃO PAULO, 1991b).

É neste panorama que a Operação Urbana Anhangabaú propôs a Transferência de Potencial Construtivo para os imóveis classificados como Z8.200 e aos que viessem a ser tombados, sendo posteriormente replicado para a Operação Urbana Centro, com a inclusão dos imóveis tombados no escopo e, admitindo a transferência de potencial para imóveis localizados dentro ou fora do perímetro da operação, desde que atendidas todas as condições estipuladas pela lei.

\footnotetext{
151 Segundo o art. -10 do Decreto-Lei n-25 de 1937 a abertura de tombamento se configura como um tombamento provisório conforme esteja o respectivo processo iniciado pela notificação ao proprietário (BRASIL, 1937).

152 Aditada pela Resolução CONPRESP 11/ 91 (CONPRESP, 1991b).

153 Resolução CONPRESP 37/92 (CONPRESP, 1992).

154 Estes dois artigos foram agregados na Resolução 37/92 por seu artigo 6ำ (CONPRESP, 1992).
} 
A Transferência de Potencial Construtivo no contexto da Operação Urbana Centro pode ser realizada, considerando o Coeficiente de Aproveitamento (CA) efetivo do lote tombado, para imóveis dentro ou fora do perímetro da Operação desde que atenda parâmetros estabelecidos pela lei. Para imóveis preservados cujo CA seja menor ou igual a sete e meio a transferência será efetuada considerando a diferença entre o potencial do lote e o CA máximo igual a 12 (doze). Já os imóveis que tenham $C A$ efetivo maior que sete e meio deverão fazer uso das seguintes regras: se a área construída atingir o limite igual a 12 (doze) vezes a área do lote, este só poderá transferir uma quantidade de potencial equivalente a $60 \%$ (sessenta por cento); nos casos em que a área construída excedente se encontrar entre o limite de 12 (doze) a 15 (quinze) vezes a área do lote, este poderá realizar a transferência de quantidade equivalente a $40 \%$ e; por último, caso a área construída exceda 15 (quinze) vezes a área do lote, o proprietário do imóvel poderá transferir uma quantidade equivalente a $20 \%$ do potencial construtivo de seu imóvel (SÃO PAULO, 1997a, art. $7^{\circ}$ ).

O interessado em participar de um processo de transferência deverá pagar o valor do terreno por $\mathrm{m}^{2}$ conforme consta na Planta Genérica de Valores ${ }^{155}$ correspondente $\mathrm{a}$ área do terreno necessária para construir a área excedente àquela permitida pela legislação de uso e ocupação do solo vigente (SÃO PAULO, 1997a, art. 5). Para efeito da transferência de potencial construtivo será considerado o valor do $\mathrm{m}^{2}$ que receberá o adicional, e não o do lote tombado que irá transferir a área excedente. A Lei da Operação Urbana Centro propõe um equilíbrio de valores através do cálculo de valores equivalentes, ou seja, se a transferência for realizada para um local onde o valor do $\mathrm{m}^{2}$ seja menor que na área central, o valor de área construída a ser transferida será maior e vice-versa, conforme podemos observar no quadro 4.1 abaixo.

\footnotetext{
155 Instrumento responsável por estabelecer os valores unitários de metro quadrado de terreno e de construção do Município (SÃO PAULO, 2014).
} 


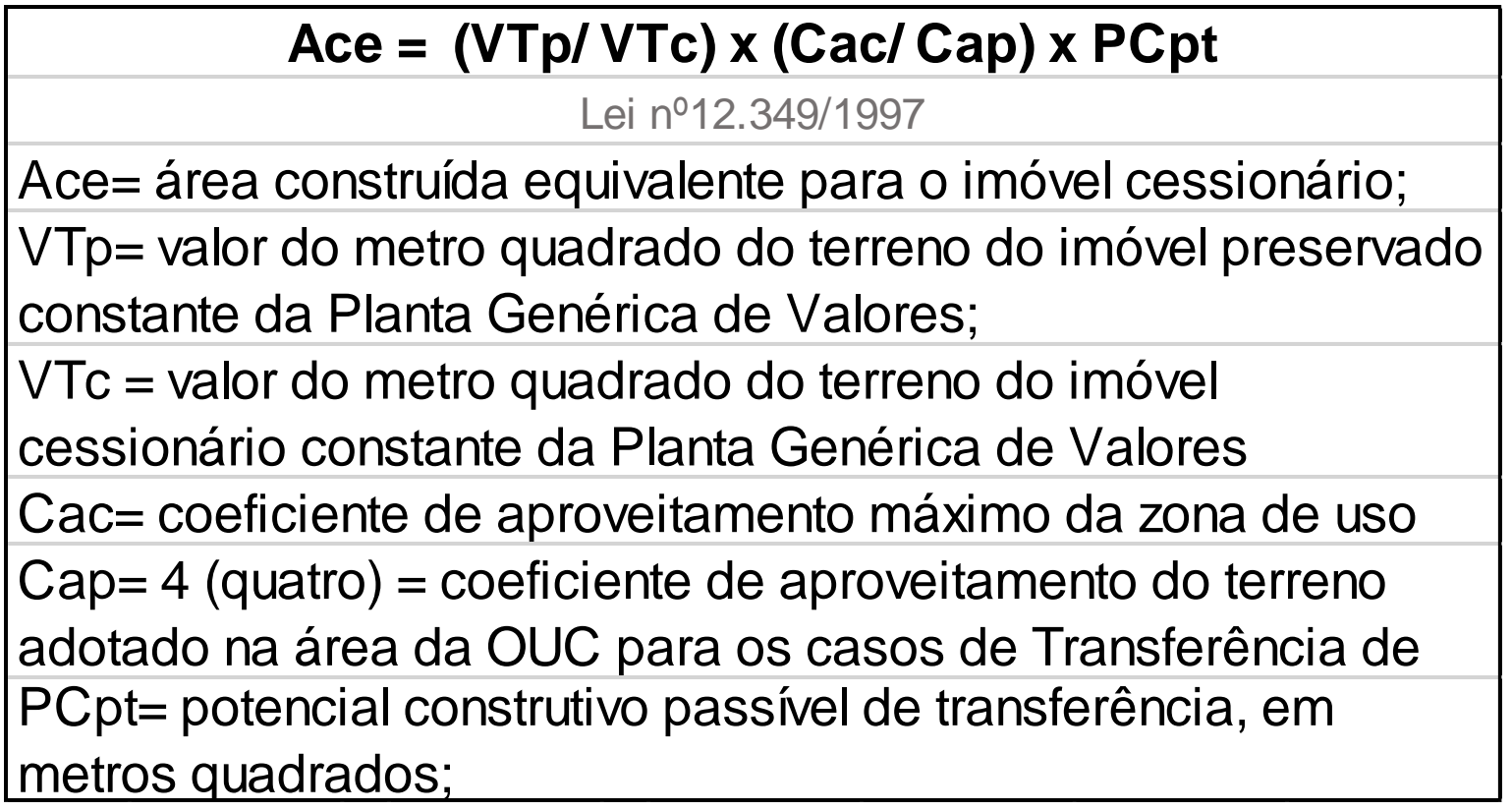

Quadro 4.1 - Fórmula para cálculo do potencial construtivo passível de transferência. Tabulação da autora. Fonte: SÃO PAULO, 1997a

Ao adotar o CA efetivo do imóvel tombado a lei permitiu estipular os índices de CA máximo, conforme descrito no parágrafo anterior, pois se o CA fosse único não seria possível efetivar várias faixas para a transferência de potencial. Contudo, ao estabelecer, para efeito de cálculo da área construída equivalente para o imóvel cessionário, como coeficiente de aproveitamento o fator máximo admitido na zona a receber a transmissão, a legislação da Operação Urbana Centro direcionou a transferência para a antiga zona $Z 2^{156}$, que abrangia a maior parte do território da cidade e cujo CA era igual a um. Ou seja, esta se enquadrava perfeitamente na prerrogativa exposta pela Lei nำ12.349/97, que estabelece,

O coeficiente de aproveitamento final do imóvel cessionário não poderá exceder a 4 (quatro) vezes a área do lote ou a 1,5 (uma e meia) vezes o coeficiente de aproveitamento máximo da zona de uso onde está localizado, prevalecendo o maior valor (SÃO PAULO, 1997a, art. 7º , inciso IV).

A operacionalização da TPC era realizada em duas etapas (SPURBANISMO, 1997). A primeira, consistia na cessão de potencial construtivo, ou seja, o proprietário

156 Lei no 7.805 de 01 novembro de 1972. (SÃO PAULO, 1972) 
de imóvel tombado ${ }^{157}$ na área da Operação Urbana Centro solicitaria a Comissão Executiva sua Declaração de Potencial Construtivo. Para esta fase, ele não necessitaria ter um comprador de potencial, podendo guardar a declaração para quando alguém se interessasse em comprá-la. Após o protocolamento, a proposta seria analisada pelo Grupo Técnico de Trabalho (GTT), ficando este encarregado de analisar e enviar a proposta ao Departamento do Patrimônio Histórico de São Paulo (DPH) para realização da análise do projeto de restauro e emissão de parecer técnico. Caso o projeto de restauro fosse aprovado, o processo deveria ser encaminhado à Comissão Executiva da OUC para verificação das análises (GTT e DPH), adequação e aprovação da proposta com posterior redirecionamento à Comissão Normativa de legislação Urbanística (CNLU) ${ }^{158}$ que era a responsável pela emissão da aprovação e declaração (EMURB, 1997).

Considerando a hipótese em que o proprietário desejasse receber o benefício, este deveria ter um comprador do potencial, ou solicitar a EMURB a indicação de um provável comprador. Assim, após a emissão do parecer favorável da CNLU, o projeto de restauro seria analisado pela Empresa Municipal de Urbanização (EMURB) ${ }^{159}$ para verificação do orçamento da obra e, em seguida seriam convocados o cedente e o cessionário para afirmação do Termo de Compromisso, que objetivava regulamentar a destinação do recurso financeiro obtido pelo cedente para restauro do imóvel tombado. Contudo, o benefício somente seria liberado com a comprovação da execução da obra e emissão, pelos órgãos competentes ${ }^{160}$, do termo técnico de aceitação da conclusão desta. Ou seja, ele só receberia o benefício após ter utilizado dinheiro próprio para realização da obra (EMURB, 1997).

A segunda etapa, dizia respeito ao trâmite necessário para compra do potencial construtivo pelo cessionário. O interessado em participar da OUC deveria protocolar processo específico, contendo peças gráficas e demais documentos, na Secretaria Municipal de Habitação (SEHAB), para que fosse realizada análise pelo GTT que em

\footnotetext{
157 Utilizaremos a partir deste ponto o termo cedente, para o proprietário do imóvel tombado e cessionário para o comprador do potencial construtivo do referido imóvel. Conforme estabelecido pela Lei no 12.349/97(SÃO PAULO, 1997a).

158 Atual Câmara Técnica de legislação Urbanística (CTLU).

159 Após sanção da Lei no 15.056, o Decreto no 51.415, de 16 de abril de 2010 regulamentou a cisão da Empresa Municipal de Urbanização (Emurb) em duas empresas. Foram criadas então a São Paulo Urbanismo (SP Urbanismo) e a São Paulo Obras (SP Obras) (SÃO PAULO, 2010).

160 A EMURB e o DPH eram os responsáveis por acompanhar a obra de restauro.
} 
sequência solicitaria ao proprietário do imóvel ou seu responsável legal a emissão do laudo de avaliação, documento onde seria especificado o valor de mercado do $\mathrm{m}^{2}$ do terreno do imóvel preservado. Após análise do método empregado para aferição do custo, o valor deste serviria de referência para o cálculo do benefício a ser concedido, considerado como sendo o valor da área do terreno necessária para construir a área excedente.

\begin{tabular}{|l|}
\hline \multicolumn{1}{|c|}{ B = Vtm } \\
B = benefício; \\
Vtm = valor do metro quadrado de \\
terreno apurado com o Laudo de \\
avaliação;
\end{tabular}

Quadro 4.2 - Fórmula para cálculo do benefício. Tabulação da autora. Fonte: Lei no 12.349/97 (SÃO PAULO, 1997a)

\begin{tabular}{|c|}
\hline CF $>50 \%$ B \\
CF = contrapartida financeira; \\
B = benefício
\end{tabular}

Quadro 4.3 - Fórmula para cálculo contrapartida financeira. Tabulação da autora. Fonte: Lei no 12.349/97 (SÃO PAULO, 1997a)

Após análise do laudo pelo GTT, este encaminharia seu parecer a Comissão Executiva que, em caso de deliberação favorável publicaria a resolução no Diário Oficial do Município e convocaria o cessionário e o cedente para realizarem a negociação da transferência. Após este passo a CNLU receberia o parecer e estipularia a definição dos Termos de Compromisso, responsável por vincular a destinação da contrapartida financeira obtida pelo cedente para o restauro do imóvel tombado. O cessionário deveria realizar o pagamento da contrapartida à vista depositando-a em conta específica da EMURB, mas com destinação ao restauro do imóvel cedente, mediante apresentação de carta de fiança bancária, e com isso receberia o Termo de Quitação que possibilitaria a emissão da Certidão de Potencial Transferido. 
O Termo possibilitaria a este requerer o alvará de aprovação e execução da obra, através de processo específico. Ressaltamos que a proposta de compra também poderia ser realizada sem estar atrelada a uma cessão, cabendo, neste caso, ao gestor da OUC fazer executar a compatibilização das trocas, posteriormente, de acordo com a disponibilidade de áreas (EMURB, 1997).

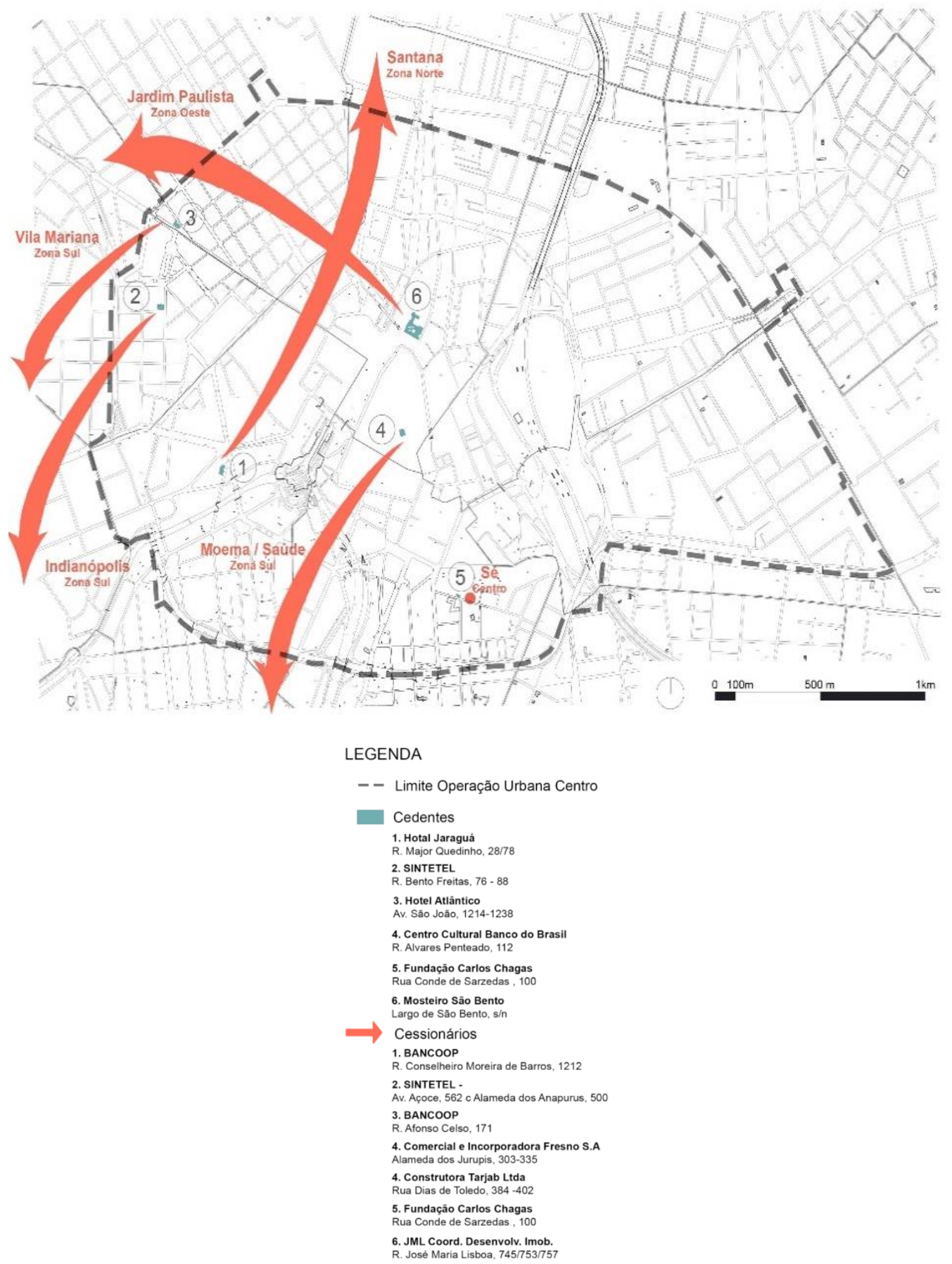

Figura 4.1 - Mapa cedentes e cessionários. Tabulação da autora sobre o Mapa Digital da Cidade com dados obtidos Diário Oficial do Município. Fonte: GEOSAMPA, 2017; DOM, 1997/ 2017. 


$\begin{array}{cccc}\text { № Mapa } & \text { CESSIONÁRIO } & \text { ZONA DE USO - 1997 } & \text { ANO PROCESSO } \\ \mathbf{1} & \text { Rua Cons. Moreira de Barros } & \text { Z2 } & 1998 \\ \mathbf{2} & \text { Avenida Açocê } & \text { Z2 } & 1998 \\ \mathbf{3} & \text { Rua Afonso Celso } & \text { Z2 } & 1998 \\ \mathbf{4} & \text { Alameda dos Jurupis } & \text { Z2 } & 1998 \\ \mathbf{4} & \text { Rua Dias de Toledo } & \text { Z2 } & 2000 \\ \mathbf{5} & \text { Rua Conde de Sarzedas } & \text { Z5 } & 2002 \\ \mathbf{6} & \text { Rua José Maria Lisboa } & \text { Z3 } & 2016\end{array}$

Quadro 4.4 - Tabulação da autora sobre dados disponibilizados pela SP-Urbanismo. Fonte: Diário Municipal de São Paulo, 1998-2016.

Como podemos observar na Figura 4.1, as transferências de potenciais construtivos, em sua maioria, foram realizadas para fora do perímetro da OUC. Em 1999, este mecanismo foi interditado pela Ação Direta de Inconstitucionalidade (ADIn) ${ }^{161}$ promovida pelo Ministério Público Estadual. Alegando que a Lei Municipal não tinha competência para delegar ao Poder Executivo o estabelecimento de normas de zoneamento, uso e ocupação do solo, índices urbanísticos e outras limitações administrativas fora da área da Operação Urbana. Um ano após, o Tribunal de Justiça declarou inconstitucional o parágrafo $1^{\circ}$ do artigo $6^{\circ}$ da lei 12.349/91 (CONJUR, 2004).

Com a aprovação do Plano Diretor Estratégico em 2002, as condições de TPC no perímetro da OUC foram regulamentadas. Este estabeleceu em seu artigo $220^{\circ}$ que a transferência poderia ser realizada para Áreas de Projetos Estratégicos, onde o coeficiente básico poderia ser ultrapassado. Essas áreas encontravam-se nas faixas de até $300 \mathrm{~m}$ ao longo dos eixos de transporte público de massa e no entorno, considerando raio de $600 \mathrm{~m}$, de estações de trem e metrô, preenchendo assim as lacunas questionadas pela ADIn (SÃO PAULO, 2002).

Em 2004, mesmo ano da aprovação da Lei de Zoneamento, o relator do Supremo Tribunal Federal autorizou o prosseguimento das ações de transferência. Entretanto, para evitar riscos futuros à municipalidade, a assessoria jurídica da Secretaria Municipal do Planejamento (SEMPLA) solicitou que fossem avisados os interessados - cedentes e cessionários -, que as propostas teriam prosseguimento com base no referendo supracitado e, que este procedimento necessitaria prévia ciência por parte destes. Em 2010, a Procuradoria Geral do Município (PGM) se

161 Segundo informação prestada pela SPUrbanismo até 04.05.2016 a Ação de Inconstitucionalidade encontrava-se pendente de julgamento. 
pronunciou favoravelmente à continuidade dos processos de solicitação da TPC para fora do perímetro da Operação Urbana Centro, com base no referendo do STJ (HECK, 2017).

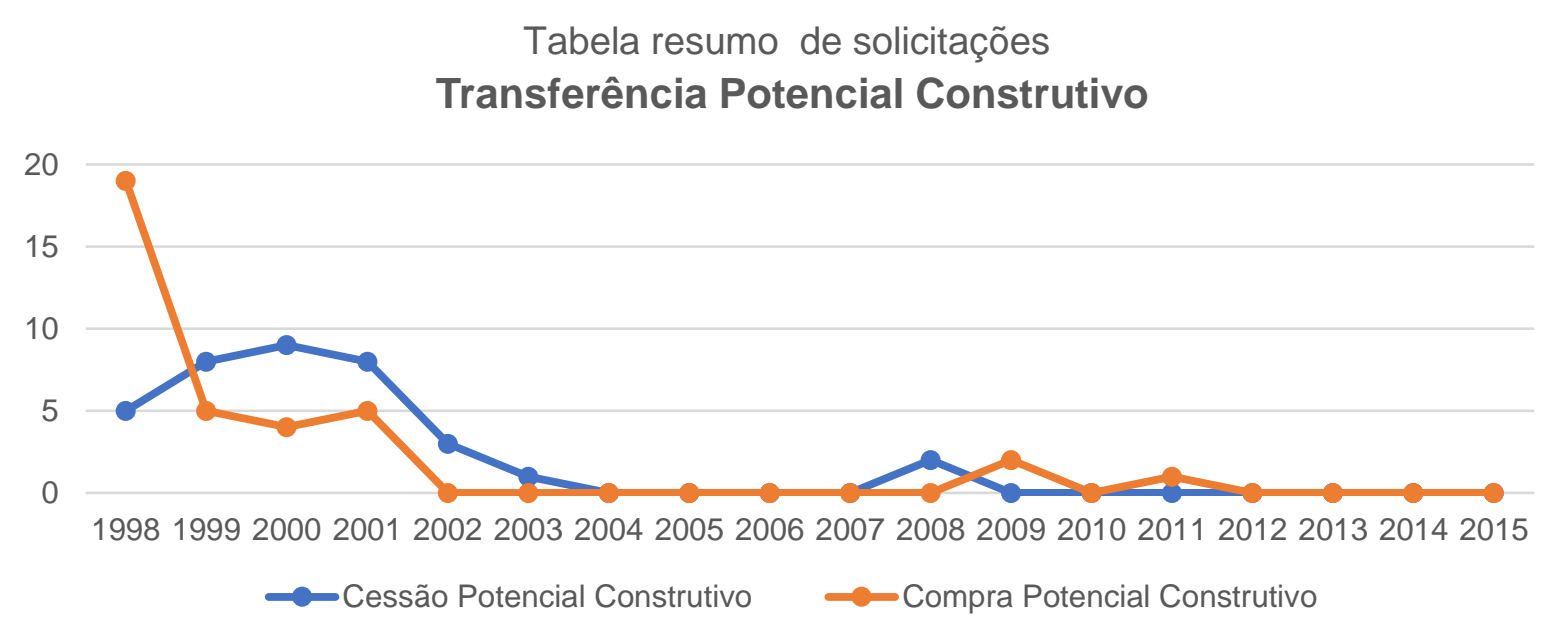

Figura 4.2 - Movimentação de cessão e compra de potencial construtivo no período de 1998 a 2015, excetuando os anos 2016 e 2017 cujos relatórios não foram publicados. Tabulação da autora sobre relatórios anuais/semestrais da SP-Urbanismo. Fonte: D.O.M., 2018.

Analisando o gráfico, na Figura 4.2, desde o início da Operação Urbana podemos observar a grande demanda por compra em relação a baixa oferta por cessão. Porém, no ano 2000, quando o estoque de cessão aumenta, eram os anos imediatamente anteriores a aprovação do Estatuto da Cidade e do Plano Diretor Estratégico do Município de São Paulo e o receio de alteração na lei pode ter contribuído para esta elevação na procura. Neste mesmo ano, é estabelecida a ADIn, e podemos perceber através do gráfico a queda no interesse de compra, pois as propostas já realizadas ficaram sob custódia, sem prazo para prosseguimento estabelecido.

Ainda analisando a Figura 4.2, entre 2007 e 2009 vemos que o interesse em cessão e compra retorna, relacionamos esta procura com o ótimo momento que o setor da construção civil passava no país. Mas, ainda assim, são ínfimas as ofertas de transferência, se considerarmos o estoque de imóveis tombados na região. $E$ a isso relacionamos o fato do trâmite para obtenção da certidão de potencial construtivo ser extenso, também devemos considerar a questão dos gastos, com projeto e laudo, como fatores que cooperaram para a redução na procura pelo incentivo, ainda mais 
se considerarmos que proprietário somente receberia o incentivo quando da comprovação de execução da obra de restauro. Outra questão não menos importante, e que pensamos estar dentre os fatores para a baixa demanda pela TPC, se concentrava na negociação do instrumento entre as partes interessadas. Pois, se uma delas desistisse do processo de negociação, ou se o projeto de uma das partes fosse negado, a outra seria prejudicada pela paralisação e a transação poderia ser realizada somente em parte ou até mesmo, não ser realizada.

4.1.1 Norma de Procedimento SP-Urbanismo 2016, aproximando o benefício do beneficiário (?).

Considerando todos os entraves analisados ao longo de 20 (vinte) anos da Transferência do Potencial Construtivo no contexto da Operação urbana Centro, bem como a necessidade de ajuste ao Plano Diretor (SÃO PAULO, 2014) vigente, a SP Urbanismo, com apoio das demais secretarias envolvidas na operacionalização da OUC, realizou, em 2016, a adequação da Norma de Procedimentos ${ }^{162}$ para solicitação da Transferência de Potencial Construtivo, ao invés de revisar a lei que rege a Operação Urbana Centro. Lembrando que já foram aprovados dois Planos Diretores e o Estatuto da Cidade - marco legal -, porém a legislação da OUC continua a mesma. Pois, conforme debate ocorrido numa das reuniões da comissão executiva a justificativa em fazer ajustes apenas na Norma recai sobre a rapidez deste o que no caso da lei requereria tempo e processo mais demorados, contudo, a revisão da Norma de Regimento não exime a obrigação de rever a Lei da Operação Urbana Centro a qual, segundo também foi informado nesta reunião, encontra-se em andamento (SPURBANISMO, 2016).

162 Norma de procedimentos (SPURBANISMO, 2016). 


\section{DECLARAÇÕES DE TRANSFERÊNCIA \\ DE POTENCIAL CONSTRUTIVO \\ $1998-2016$ \\ E Antes do PDE 2014 EApós PDE 2014}

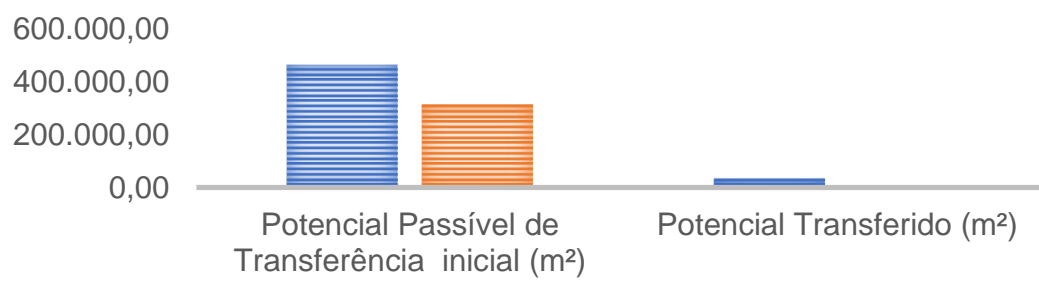

Figura 4.3 - Análise das declarações de potencial construtivo emitidas até 2016. Tabulação da autora. Fonte: SPURBANISMO, 2016,online.

Conforme podemos vislumbrar na Figura 4.3, a revisão é urgente pois a área central dispõe de um estoque que não está sendo utilizado e isto devido ao mecanismo ultrapassado que se tornou a Lei da OUC. O Plano Diretor de 2014 implementou novos parâmetros para a Transferência do Direito de Construir ${ }^{163}$ ao estipular coeficiente de aproveitamento único para o território da cidade, e ao possibilitar a transferência para o município todo, mas também abriu o leque dos beneficiários $^{164}$ da TDC e isso gerou uma competição entre a TDC e a TPC, onde a segunda vem perdendo campo.

Pela NP, aprovada no final de 2016, o procedimento de transferência de potencial construtivo continua a ser realizado em duas etapas sendo que a primeira consiste em emitir a Declaração de Potencial Construtivo Passível de Transferência, assim como o valor de área passível de ser transferida. E a segunda etapa se concentra na emissão da Certidão de Potencial Construtivo Transferido para o cessionário, seja este parcial ou total, desde que respeitando o limite estabelecido pela legislação como coeficiente de aproveitamento máximo para o imóvel cessionário (SPURBANISMO, 2016).

A primeira alteração realizada em relação ao procedimento antigo diz respeito ao protocolamento da proposta de transferência, pois agora ela é realizada pelo cedente através de um único processo ao qual são juntadas as propostas de

${ }^{163}$ A Lei 16.050 de 31 de julho de 2014 passa a adotar esta designação para a transferência realizada fora do perímetro da Operação Urbana Centro. (SÃO PAULO, 2014)

${ }_{164}$ Agora a TDC é autorizada para a execução de melhoramentos viários. Programas de habitação social e de regularização fundiária, áreas verdes, parques e zonas de proteção ambiental. (SÃO PAULO, 2014) 
cessionários até que seja realizado a venda total do Potencial Construtivo passível de transferência (PCpt) e, com isso, o encerramento e arquivamento do processo. $\mathrm{Ou}$ seja, a transferência nesta fase, não conta mais com a atuação do gestor, que no procedimento anterior ficava responsável por realizar a interlocução entre cedente e cessionário. A TPC passou, a partir de 2016, a ser realizada diretamente entre os interessados, a SPUrbanismo ficou desobrigada de gerenciar o valor, pago pelo cessionário, depositado em conta específica. Assim como não será mais responsável por fiscalizar e atestar a obra de restauro, ficando este serviço como responsabilidade somente do Departamento do Patrimônio de São Paulo (SPURBANISMO, 2016b).

Outra modificação em relação ao procedimento anterior recai sobre o projeto de restauro. O proprietário não necessita protocolar um projeto aprovado ${ }^{165}$ pelo CONPRESP para solicitar a TPC, ou mesmo ter um projeto. Expliquemos melhor, a partir da aprovação do PDE em 2014, o DPH conjuntamente com apoio técnico de outras secretarias realizou uma série de reuniões e alguns estudos para avaliar a efetividade do benefício da TPC e da TDC, estes resultaram no estabelecimento da Resolução 23/2015, que firmou diretrizes para análise do estado de conservação do imóvel tombado objeto de concessão de benefícios e incentivos fiscais e urbanísticos (CONPRESP, 2015).

Consideramos esta Resolução um avanço principalmente por abordar a questão daquele proprietário que não dispõe de condições financeiras para arcar com o custo do projeto de restauro, primeiro item solicitado numa proposta para obtenção de benefícios à conservação, neste caso a TPC. Outro ponto de destaque se situa na cobrança de um plano de manutenção permanente para o bem de interesse cultural edificado. Ao exigir que seja realizado um plano, o Departamento espera assegurar a periodicidade dos serviços de manutenção e conservação, primeira medida necessária para se evitar uma obra de restauro, tanto por seu grau de complexidade quanto pelo seu custo (CONPRESP, 2015).

A Comissão Executiva ao debater e formular a Norma de Procedimentos agregou as disposições da Resolução estabelecida pelo CONPRESP e com isso abriu

\footnotetext{
165 O proprietário deveria comprovar a autorização do projeto ou ter em mãos o protocolo de autuação, caso este tivesse realizado o procedimento apartado da SP-Urbanismo, caso contrário ele deveria autuar o processo em SEHAB e essa se encarregaria de enviar ao DPH que depois encaminharia a SP-Urbanismo, como discorremos anteriormente. (CONPRESP, 2015)
} 
o leque para utilização da TPC, ao permitir que o proprietário de imóvel tombado faça uso do benefício para custear o projeto de restauro, desde que assine um Termo de Compromisso, junto ao órgão de preservação, explicitando quais ações e etapas serão efetuadas, ficando a transferência restrita ao suficiente para financiar o desenvolvimento do projeto (CONPRESP, 2015; SPURBANISMO, 2016).

Caso o proprietário tenha utilizado a transferência para realizar o projeto de restauro, mas ainda disponha de saldo de PCpt, este deverá protocolar novo processo, solicitando a transferência com vistas à execução da obra. Lembramos que o Termo de Compromisso deverá ser assinado tanto para efeito do benefício custear a proposta de projeto quanto de obra de restauro, ou seja, o Termo de Compromisso passa a ser obrigatório, sendo também o documento responsável por liberar o cedente para recebimento da contrapartida financeira, e com ele a responsabilidade da SPUrbanismo sobre o tema do restauro se extingue e passa àquele que por designação detém o conhecimento para advogar sobre o tema, o Departamento do Patrimônio Histórico.

A comercialização da Transferência de Potencial Construtivo pode ser realizada a partir do momento em que o cedente assina o Termo de Compromisso de Restauro com o DPH. Diferentemente do que ocorria no procedimento anterior, onde somente ao final da obra, desde que esta tivesse sido realizada inteiramente de acordo com as diretrizes dos órgãos responsáveis, o proprietário poderia receber o saldo da transferência. Concluindo, agora a TPC atua realmente como um benefício, ao possibilitar que o montante arrecado com a transação seja empregado na conservação do patrimônio cultural edificado (CONPRESP, 2015; SPURBANISMO, 2016).

Com o novo regulamento, caso o imóvel seja atestado pelo órgão de preservação que está em perfeitas condições será emitido Atestado de Conservação do imóvel, desde que seu proprietário apresente ao DPH o plano de manutenção permanente do bem protegido, conjuntamente com uma série de documentos solicitados pelo órgão. Este atestado tem validade de 3 (três) anos, ao longo dos quais serão realizadas vistorias para acompanhamento do estado de conservação da construção. Caso seja constatado o não cumprimento do plano, fica o proprietário sujeito às penalidades previstas na legislação vigente (CONPRESP, 2015). 
A NP 59.00 (SPURBANISMO, 2016) disponibilizou o método para cálculo do Benefício da Contrapartida Financeira que, anteriormente era estipulado na lei, mas sem uma fórmula específica. Na fórmula de agora, o valor do benefício, antes estipulado em função da área necessária para construir a área excedente, considera o índice de desconto da contrapartida, oficialmente, como 0,7 (zero vírgula sete) e passa a nomeá-lo com fator desvalorizante, conforme o Quadro 4.5.

\begin{tabular}{|l|}
\hline \multicolumn{1}{|c|}{ B = ACe x Vtm x Fd } \\
\hline$B=$ Valor econômico referente ao Benefício; \\
$A C e=$ Área construída equivalente para o imóvel cessionário; \\
Vtm = Valor de m2 de terreno apurado em Laudo de Avaliação; \\
$\begin{array}{l}F d=0,7 \text { (sete décimos) - Fator desvalorizante atribuído ao } \\
\text { "terreno virtual"; }\end{array}$ \\
\hline
\end{tabular}

Quadro 4.5 - Fórmula para cálculo do Benefício. Tabulação da autora sobre base disponibilizada pela NP 59.00 SP - Urbanismo, 2016. Fonte: DOM, 2016.

A adoção do fator 0,7 (zero vírgula sete), conforme pudemos acompanhar nas discussões realizadas pela Comissão Executiva em suas reuniões, teve como embasamento os fatores de incentivo, aplicados pela Lei de Uso de Ocupação do Solo (LPUOS), de 2016. Mas esta dispõe de sete categorias onde cada uma recebe um valor numérico dependendo da área do lote. O maior lote tem um fator de incentivo menor e vice-versa. Já no caso da NP 59.00 (SPURBANISMO, 2016) não ficou clara a adoção do valor 0,7 (zero vírgula sete), que é exatamente o fator de incentivo intermediário adotado pela LPUOS, utilizado para imóveis com área de lote superior a $5.000 \mathrm{~m}^{2}$ (cinco mil metros quadrados) até $10.000 \mathrm{~m}^{2}$ (dez mil metros quadrados). Pois, se um lote de $1050 \mathrm{~m}^{2}$ (um mil e cinquenta metros quadrados), hipoteticamente ${ }^{166}$, utilizar o fator 0,7(zero vírgula sete) o benefício terá um valor menor que se este utilizasse o fator 1 (designado pela LPUOS para áreas desta extensão), logo, o proprietário de imóvel tombado receberá um benefício menor àquele que teria direito e, ainda, fica em desvantagem frente a um proprietário que tem imóvel tombado fora do perímetro da OUC (SÃO PAULO, 1997).

\footnotetext{
166 Para este exemplo utilizamos um lote em Santana com área de 1050 m2, em novembro de 2017, para o qual desejávamos construir 144 unidades habitacionais de $41 \mathrm{~m}^{2}$. E como valor de $\mathrm{m}^{2}$ apurado em laudo, utilizamos terreno na Santa Efigênia cujo preço do metro ${ }^{2}$ custava $R \$ 7.212,07$. Fonte: Portal de imóveis VivaReal. Disponível em: https://www.vivareal.com.br Acesso em: 18 nov. 2017
} 
As alterações realizadas através da NP 59.00 (SPURBANISMO, 2016) abrangeram também a questão da contrapartida financeira que não estava definida especificadamente nem na Lei no 12.349/97 (SÃO PAULO, 1997a). muito menos na norma anterior. O cálculo de referência para contrapartida financeira anteriormente estava atrelado ao custo orçado no projeto de restauro, porém, agora não mais. O valor referencial para cálculo da contrapartida será definido pela Comissão Executiva e não poderá exceder a $5 \%{ }^{167}$ do valor total arrecado pelo Fundo de Desenvolvimento Urbano (FUNDURB) num período de 1) meses. Outra mudança realizada está na adoção de um fator de desconto $(\mathrm{Ft})$, que deverá ser aplicado considerando a atratividade do PCpt em relação as demais possibilidades de potencial construtivo adicional (SÃO PAULO, 2016; SPURBANISMO, 2016).

\begin{tabular}{|l|}
\hline \multicolumn{1}{|c|}{ CF $=\mathbf{B}$ x Ft } \\
\hline $\mathrm{B}=$ Valor econômico referente ao Benefício; \\
$\mathrm{Ft}=$ Fator de desconto previsto no art. $10^{\circ}$ da Lei $\mathrm{n}^{\circ}$ \\
$12.349 / 97 ;$
\end{tabular}

Quadro 4.6 - Fórmula para cálculo da Contrapartida Financeira. Tabulação da autora sobre base disponibilizada pela NP 59.00 (SPURBANISMO, 2016). Fonte: DOM,2016.

\begin{tabular}{|r|l|}
\hline \multicolumn{2}{|c|}{ ÍNDICE DE DESCONTO DE CONTRAPARTIDA FINANCEIRA } \\
\hline $0,5-$ & $\begin{array}{l}\text { para propostas que possam fomentar o } \\
\text { desenvolvimento econômico, social e cultural da } \\
\text { área central }\end{array}$ \\
\hline $0,7-$ & $\begin{array}{l}\text { propostas cujo interesse urbanístico é relativo e } \\
\text { localizado }\end{array}$ \\
\hline $1-$ & propostas sem relevante interesse urbanístico \\
\hline
\end{tabular}

Quadro 4.7 - Relação dos índices de desconto passíveis de aplicação na fórmula da contrapartida financeira. Tabulação da autora sobre base disponibilizada pela NP 59.00 (SPURBANISMO, 2016). Fonte: DOM, 2016.

Ao vincular a $5 \%$ o valor referencial da transferência de potencial construtivo no perímetro da OUC a Lei no16.050/16 enfraqueceu o instrumento tornando-o menos

\footnotetext{
167 Toda transferência, de potencial construtivo ou de direito de construir, realizada no município de São Paulo fica restrita a 5\% do valor arrecadado anualmente pelo FUNDURB. (SPURBANISMO, 2016)
} 
atrativo que outras formas de exceção a legislação de uso e ocupação do solo. Se considerarmos que a maior quantidade de edificações tombadas se encontram na área central de São Paulo, perfazendo um total de 600 imóveis, a limitação a uma porcentagem de $5 \%$ do FUNDURB diminuiu o total de comercialização do potencial e, ainda, prejudicou o pequeno proprietário que detém imóvel na área central pois os fatores de correção previstos na LPUOS não são aplicáveis no perímetro da OUC (SÃO PAULO, 2016).

Ainda é muito recente a revisão da Norma de Procedimentos, mas iremos realizar uma breve análise através do estudo de caso do Mosteiro São Bento, primeiro imóvel a utilizar o novo procedimento. Para isso, antes examinaremos a aplicação da Norma de Procedimentos adotada anteriormente a 2016, no estudo de caso do Hotel Jaraguá. Os dois casos foram escolhidos como objeto de exploração devido à complexidade que se deu com a transferência de potencial de construtivo dos imóveis em questão.

\subsection{Hotel Jaraguá, um caso ainda não concluído}

O projeto do edifício foi encomendado ao arquiteto Jacques Pilon pela família Mesquita, proprietária e fundadora do jornal O Estado de São Paulo, em 1946, mas a responsabilidade final pela encomenda ficou a cargo do arquiteto Franz Heep. O prédio foi construído para abrigar a sede do jornal, os estúdios da rádio Eldorado e salas de escritórios. Mas desde sua inauguração o edifício abrigou o uso hoteleiro, do nono ao vigésimo primeiro andar (ESTADO DE SÃO PAULO, 2017). 


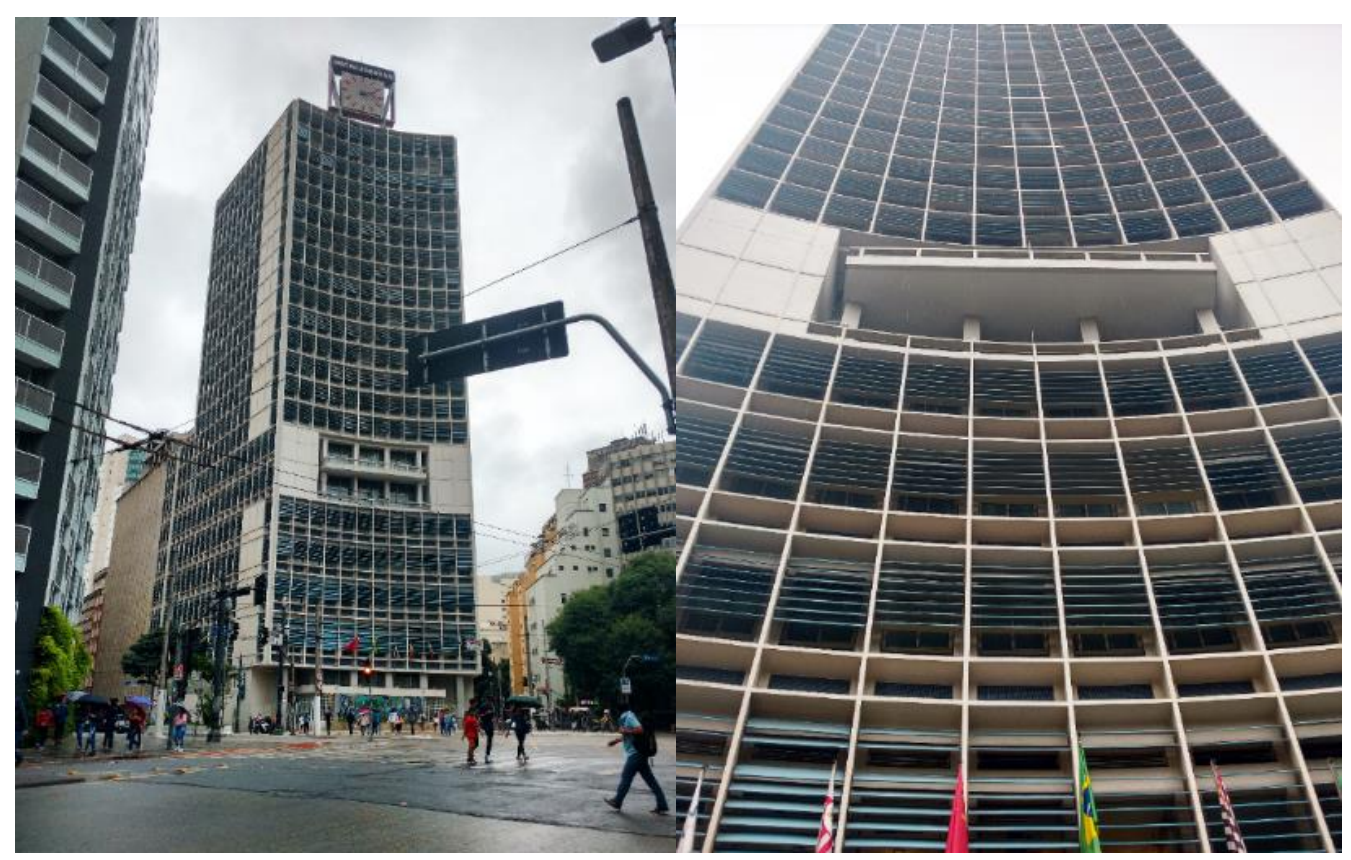

Figura 4.3 - Hotel Jaraguá vista da Rua Coronel Xavier de Toledo (imagem à esquerda) e, fachada principal do Hotel Jaraguá com seus brises (imagem à direita). Fonte: Acervo Pessoal, 2017.

Considerado um dos símbolos da arquitetura modernista na cidade de São Paulo, a construção ostenta brises móveis, volumetria imponente, painéis de artistas consagrados e um grande relógio no topo. O edifício foi tombado pelo Conselho Municipal de Preservação do Patrimônio Histórico, Cultural e Ambiental da Cidade de São Paulo (CONPRESP) através da Resolução 37/1992 (CONPRESP, 1992) - que versa sobre o tombamento do Vale do Anhangabaú. Inaugurado em 1954, tendo conhecido seu auge como um dos melhores hotéis da cidade entre 1950 e 1960, entrou em declínio nos anos de 1970, quando novos hotéis do mesmo porte foram inaugurados na região central, para, em 1998 ser desativado (ALVAREZ; CAMPOS, 2007). 


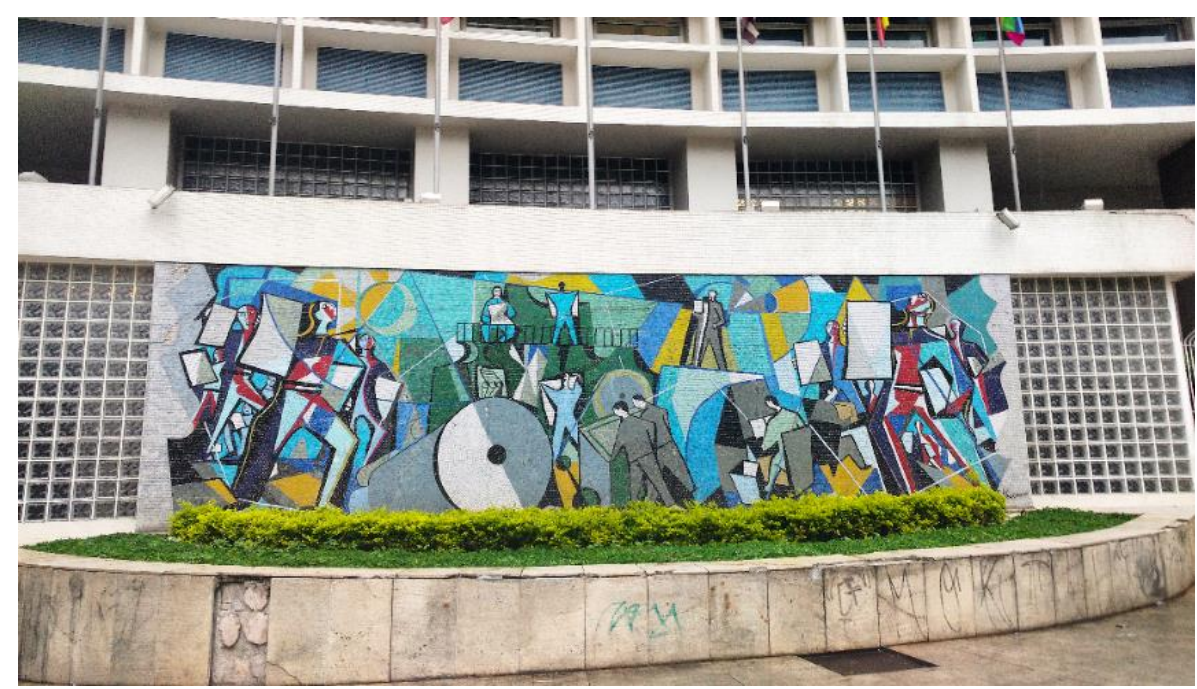

Figura 4.4 - Hotel Jaraguá - painel de Di Cavalcanti. Fonte: Acervo Pessoal, 2017.

Ainda em 1998, o edifício, que já havia passado por vários proprietários, foi vendido novamente e o novo dono, aproveitando o período de intervenções e investimentos na área central naqueles anos, propôs a modificação do uso utilizando os incentivos oferecidos pela Operação Urbana Centro. Para isso contratou o escritório de arquitetura Miguel Juliano que ficou responsável por propor as alterações necessárias ao edifício existente adaptando-o, em sua plenitude, para abrigar um hotel. No último mês deste mesmo ano foi protocolado o processo de pedido de Transferência de Potencial Construtivo (TPC) na antiga EMURB, atual SPUrbanismo.

É importante ressaltar que o Hotel Jaraguá, além do benefício da Transferência de Potencial Construtivo, poderia se utilizar de outro benefício concedido no âmbito da Operação Urbana Centro, pois aos hotéis de turismo, categoria S2.05, a Operação Urbana oferecia condições mais atrativas que a lei vigente ${ }^{168}$ conforme podemos observar no quadro 4.8 .

\begin{tabular}{|c|c|c|c|c|c|c|c|c|c|c|}
\hline \multicolumn{11}{|c|}{ CATEGORIA D USO S2.05 } \\
\hline & \multirow[b]{2}{*}{$\begin{array}{c}\text { Zona de } \\
\text { Uso }\end{array}$} & \multirow{2}{*}{$\begin{array}{c}\text { Área } \\
\text { mínima } \\
\text { de } \\
\text { terreno }\end{array}$} & \multicolumn{3}{|c|}{ Coeficiente de Aproveitamento } & \multicolumn{2}{|c|}{ Taxa de Ocupação Máxima } & \multirow{2}{*}{$\begin{array}{c}\text { Porcentagem } \\
\text { mínima de } \\
\text { terreno } \\
\text { arborizado }\end{array}$} & \multicolumn{2}{|c|}{ Recuos mínimos } \\
\hline & & & $\begin{array}{c}\text { Instalações } \\
\text { hoteleiras }\end{array}$ & $\begin{array}{c}\text { Serviços } \\
\text { ou } \\
\text { garagens }\end{array}$ & $\begin{array}{c}\text { garagen } \\
\mathrm{s}\end{array}$ & Até o $2^{\circ}$ pavimento & $\begin{array}{c}\text { Acima do } 2^{\circ} \\
\text { pavimento }\end{array}$ & & $\begin{array}{c}\text { Frente e } \\
\text { Fundo }\end{array}$ & $\begin{array}{l}\text { Ambas } \\
\text { as } \\
\text { laterais }\end{array}$ \\
\hline $\begin{array}{l}\text { Lei de } \\
\text { hotéis }\end{array}$ & Z5 & não há & 4 & 2 & 2 & $80 \%$ & $55 \%$ & $10 \%$ & \multicolumn{2}{|c|}{$\begin{array}{c}\text { mantidos os } \\
\text { recuos das }\end{array}$} \\
\hline $\begin{array}{c}\text { Lei } \\
\mathrm{n}-12.349\end{array}$ & $\begin{array}{c}\text { todas as } \\
\text { zonas }\end{array}$ & não há & 6 & 2 & 4 & $80 \%$ & $55 \%$ & $10 \%$ & \multicolumn{2}{|c|}{$\begin{array}{l}\text { mantidos os } \\
\text { recuos das } \\
\text { respectivas }\end{array}$} \\
\hline
\end{tabular}

168 Lei no 7.805 , de 01 novembro de 1972. 
O processo de TPC (P.A. 1998-0.242.750-0) foi protocolado separadamente do processo de restauro, então para prosseguimento do primeiro era necessário aguardar a anuência do projeto de modificação e acréscimo de área (P.A. 19990.020.116-7), protocolado como de restauro, para que assim fosse realizada a próxima etapa, que consistia no cálculo do potencial construtivo do lote. Entre o protocolamento do pedido de TPC e a obtenção da anuência do órgão de preservação ocorreu um período de nove meses que, se fossemos considerar o cronograma de restauro anexado ao processo, onde o período de obras estimado era de 12 meses, estas já estariam em sua fase final.

O CONPRESP, apesar de não delegar sobre o uso do bem tombado, não aprovou o projeto modificativo para edifício de uso hoteleiro, dando sua anuência somente para as obras de ampliação do ático/ cobertura. Porém, a Secretaria Municipal do Planejamento do Município de São Paulo (SEMPLA) se utilizando do artigo 4ํㅜㄹ da Resolução 37/1992, onde está escrito que "todos os bens tombados são passíveis de restauração, reciclagem, revitalização e reformas, visando sua adequação funcional, devendo os projetos serem submetidos à prévia aprovação do CONPRESP" (CONPRESP, 1992) e, considerando que o edifício foi tombado com Nível de Preservação - 2, ou seja, devem ser preservadas somente as características externas e alguns itens internos discriminados na citada Resolução, resolveu dar prosseguimento a análise da transferência de potencial construtivo não solicitando nova anuência do órgão de preservação municipal (EMURB, 1998b).

Apesar daquele momento a anuência do CONPRESP não ter sido necessária devido ao embasamento legal já citado neste texto. O técnico que emitiu o parecer não descartou a necessidade de nova consulta ao órgão de preservação quando o processo fosse enviado para a Secretaria de Habitação de São Paulo (SEHAB). O projeto apresentado era possuidor de algumas incorreções gráficas e omissão de informações, porém, mesmo assim foi dado seu prosseguimento para efeito de cálculo de Transferência de Potencial Construtivo. O cálculo foi efetuado com base no disposto pelo artigo $7^{\circ}$ da Lei oㅜ 12.349/97 (SÃO PAULO, 1997a), onde em seu inciso II, o potencial construtivo de imóveis cujo coeficiente de aproveitamento excedessem 7,5 (sete e meio) deveria ser calculado da seguinte forma: 


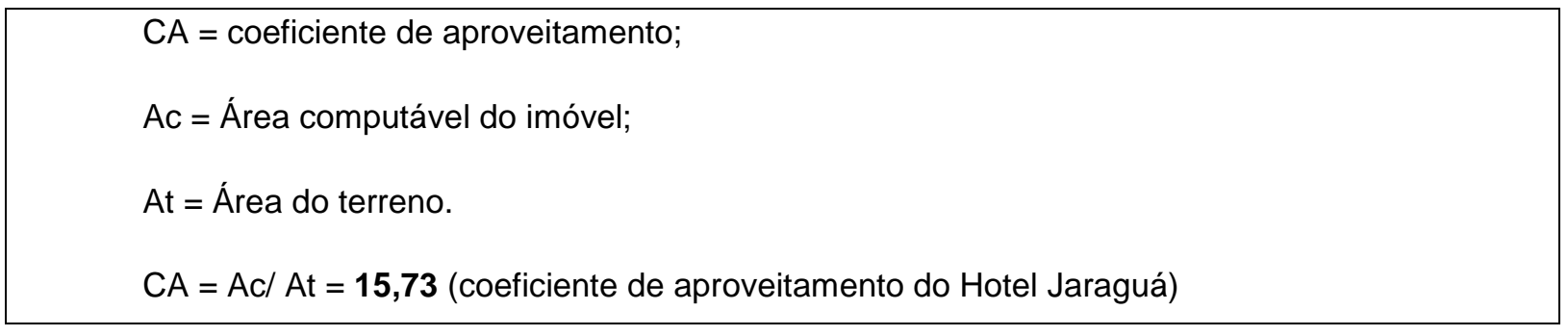

Quadro 4.9 - Fórmula para cálculo do coeficiente de aproveitamento. Tabulação da autora. Fonte: EMURB, $1998 \mathrm{~b}$.

O potencial construtivo foi calculado considerando a aplicação cumulativa de parcelas conforme disposto no artigo supracitado, e com isso se obteve o valor de $13.938,52 \mathrm{~m}^{2}$ (treze mil novecentos e trinta e oito vírgula cinquenta e dois metros quadrados) de potencial disponível para transferência. Após a realização do cálculo, foi emitida, pela SEMPLA, a Declaração de Potencial Construtivo no008, publicada no Diário Oficial do Município no dia 15 de outubro 1999.

O próximo passo seria a averiguação da planilha de custos da obra de restauro pela equipe de obras da EMURB, contudo, o proprietário, ou seu representante legal, não havia entregado material suficiente e, por isto, foi necessária a emissão de um novo comunique-se para que este complementasse o material solicitado pela municipalidade, com tabelas atualizadas, laudo de avaliação e demais documentos necessários para análise. Enquanto isso, o escritório responsável por gerenciar e coordenar as obras do edifício realizava as tratativas com o interessado em comprar o potencial construtivo.

Neste ínterim, em novembro de 1999, o proprietário do Hotel Jaraguá foi informado pela EMURB sobre a Ação de Inconstitucionalidade (ADIn), imposta pelo Ministério Público Estadual e sobre a possibilidade, ainda não confirmada, do possível embargo das tratativas. Passados alguns meses, já no ano 2000, a municipalidade informou ao proprietário que o andamento das propostas, que já se encontravam encaminhadas, teriam seu prosseguimento enquanto se aguardava o julgamento da Ação. O interessado se manifestou enviando o material complementar, composto por planilhas orçamentárias, para análise e prosseguimento do cálculo da transferência de potencial construtivo.

Lembrando que o Hotel Jaraguá dispunha de $13.938,52 \mathrm{~m}^{2}$ (treze mil novecentos e trinta e oito vírgula cinquenta e dois metros quadrados) de potencial 
passível de transferência, mas a área solicitada pela Bancoop - Cooperativa Habitacional dos Bancários, empresa interessada em comprar potencial, era da ordem de $3.367,14 \mathrm{~m}^{2}$ (três mil trezentos e sessenta e sete vírgula quatorze metros quadrados), se tratando, portanto, de venda parcial do potencial construtivo. Logo, os itens da planilha de custos deveriam ser aprovados separadamente.

Em 2001, foi assinada a Ata de Negociação de Transferência de Potencial Construtivo, nela ficava estabelecido que o cedente, na figura da SOL INVEST Empreendimentos e Participações Ltda, proprietária do imóvel situado à Rua Major Quedinho nำ 28, 44 e 76, aceitava transferir 3.367, 14m² (três mil trezentos e sessenta e sete vírgula quatorze metros quadrados) de seu potencial construtivo. Atribuindo assim, a área construída equivalente a 3.296,25m² (três mil duzentos e noventa e seis vírgula vinte e cinco metros quadrados) ao imóvel cessionário, calculada conforme estipulado no inciso III art.7º da Lei 12.349/97 (SÃO PAULO, 1997a), na figura da Bancoop - Cooperativa Habitacional dos Bancários, localizado à Rua Conselheiro Moreira de Barros, nำ1.136, 1.212 e 1.218.

Ao cessionário coube o pagamento da quantia de $\mathrm{R} \$ 619.497,418$, correspondente a 118, 34\% (cento e dezoito vírgula trinta e quatro por cento) do valor mínimo da contrapartida financeira estipulada, que não poderia ser inferior a $100 \%$ do valor econômico atribuído ao Benefício (B) nos casos de reformas ou ampliações, conforme Inciso I do art. 10ำ da Lei da O.U. Centro. O orçamento estimado para as obras de restauro era da ordem de $\mathrm{R} \$$ 9.875.000,00 (nove milhões oitocentos e setenta e cinco mil reais), logo, o valor do benefício não seria suficiente para realizálas, nem se a transferência fosse realizada em sua totalidade (CONPRESP, 1999).

O valor da Contrapartida Financeira (CF) foi calculado com base nos valores auferidos pelo laudo de avaliação considerando o valor de mercado do metro quadrado de terreno do imóvel cessionário (parágrafo $1^{\circ}$, artigo $9^{\circ}$ da Lei $n^{\circ}$ 12.350/97). Portanto, para a concessão de um benefício que visa contribuir com a conservação e preservação de um bem edificado com valor histórico e cultural, o valor de mercado do bem tombado não é considerado, ela poderia estar no lote ou não, o que será avaliado é o valor da terra no contexto urbano e não o engenho humano assentado sobre esta. Atentando que para o exercício do ano de 1998 o valor da construção, avaliado para cálculo do Imposto Predial e Territorial Urbano, se 
encontrava na faixa de $\mathrm{R} \$ 6.732 .945,00$ (seis milhões setecentos e trinta e dois mil novecentos e quarenta e cinco reais) e o valor do terreno era estimado em $R \$$ 2.047.338,00 (dois milhões quarenta e sete mil trezentos e trinta e oito reais) (SÃO PAULO, 1997a).

O pagamento da contrapartida financeira deveria ser realizado em três parcelas, conforme acordado na reunião entre os interessados. Devendo a entrada, correspondente a 33\% (trinta e três por cento) do valor total, ser realizada a vista e o restante em duas parcelas mensais mediante a comprovação, pelo cessionário, de carta de fiança bancária, ou seja, este deveria comprovar ter em conta o valor total disponível para pagamento da contrapartida. A EMURB, atual SPUrbanismo, caberia o montante de $4 \%$ (quatro por cento) sobre a CF correspondente ao pagamento pelo acompanhamento da obra e demais serviços correlatos.

Os valores foram depositados em conta bancária vinculada à execução da obra, cuja movimentação ficava condicionada à autorização da EMURB. A empresa municipal seria responsável por acompanhar a obra mensalmente e realizar medição dos serviços efetuados, devendo posteriormente verificar a compatibilização com o cronograma físico-financeiro entregue quando do protocolamento do processo de TPC, para então liberar os valores correspondentes já depositados pelo cessionário quando do pagamento da CF. Resumindo, o pagamento do benefício seria realizado mediante $o$ andamento da obra.

Após a assinatura da Ata esta foi levada a Comissão Executiva da Operação Urbana Centro para aprovação e posterior encaminhamento a antiga Comissão Normativa de Legislação Urbanística (CNLU) para aprovação da proposta de transferência de potencial construtivo, publicação no Diário Oficial do Município e emissão da Declaração de Potencial Construtivo. 


\begin{tabular}{|c|c|}
\hline \multicolumn{2}{|r|}{ Dados Cedente } \\
\hline $\begin{array}{l}\text { Compromissário } \\
\text { cedente: }\end{array}$ & $\begin{array}{l}\text { SOL INVEST Empreendimentos e Participações } \\
\text { Ltda. }\end{array}$ \\
\hline № Proposta: & 31 \\
\hline № Processo: & $1998-0.242 .750-0$ \\
\hline Endereço: & Rua major Quedinho nº 28 a 76 \\
\hline Zona de uso: & Z5-002 \\
\hline Tombamento: & Resolução 37/ CONPRESP/ 92 \\
\hline \multicolumn{2}{|r|}{ Dados da Proposta } \\
\hline Tipo de obra: & $\begin{array}{l}\text { Restauro e reforma sem aumento de área } \\
\text { existente }\end{array}$ \\
\hline Categoria da obra: & S2.5 \\
\hline Área do terreno: & $1.631,00 \mathrm{~m} 2$ \\
\hline $\begin{array}{l}\text { Área construída } \\
\text { computável: }\end{array}$ & $26.653,38 \mathrm{~m} 2$ \\
\hline $\begin{array}{l}\text { Potencial construtivo } \\
\text { passível de } \\
\text { transferência: }\end{array}$ & $13.938,52 \mathrm{~m} 2$ \\
\hline Solicitatação & $\begin{array}{l}\text { Transferência de Potencial Construtivo nos } \\
\text { termos do art. } 7^{\circ} \text { da Lei nำ12.349/97 }\end{array}$ \\
\hline
\end{tabular}

Quadro 4.10 -Dados do cedente. Tabulação da autora. Fonte: DOM, 2003.

\begin{tabular}{|c|c|}
\hline \multicolumn{2}{|r|}{ Dados Cessionário } \\
\hline Compromissário cessionário: & $\begin{array}{l}\text { BANCOOP Cooperativa Habitacional dos Bancários } \\
\text { de São Paulo }\end{array}$ \\
\hline № Proposta: & 15 \\
\hline № Processo: & $1998-0.084 .005-2$ \\
\hline Endereço: & Rua Conselheiro Moreira de Barros no 1148 a1218 \\
\hline Zona de uso: & $\mathrm{Z2}$ \\
\hline Solicitação: & $\begin{array}{l}\text { Área construída computável adiconal transferida de } \\
\text { imóvel tombado nos termos do art. } 7^{\circ} \text { da lei } n^{\circ}= \\
12.349 / 97\end{array}$ \\
\hline \multicolumn{2}{|r|}{ Dados da Proposta } \\
\hline Tipo de obra: & Construção de uso residencial \\
\hline Categoria da obra: & R03.1 \\
\hline Área do terreno: & $4.185,00 \mathrm{~m} 2$ \\
\hline Área construída computável: & $11.666,25 \mathrm{~m} 2$ \\
\hline Número de blocos: & 3 \\
\hline Número de pavimentos: & $\begin{array}{l}\text { 15, } 17 \text { e } 19 \text { pavimentos - tipo, térreo, ático e } 4 \\
\text { subsolos }\end{array}$ \\
\hline Número de unidades: & 204 \\
\hline Índices urbanísticos: & $\mathrm{CA}=2,79 / \mathrm{T} . \mathrm{O}=19,67 \%$ \\
\hline
\end{tabular}


Entre 2001, ano da expedição da Declaração de Potencial Construtivo, e 2003 foram liberadas somente duas parcelas, das dezoito previstas, do benefício. Isto ocorreu devido a paralisação dos trâmites imposta pela Ação de Inconstitucionalidade. Logo, o proprietário do Hotel Jaraguá realizou a obra de restauro as suas expensas e sem acompanhamento técnico da EMURB e do Departamento do Patrimônio Histórico (DPH). Porém, para liberação dos recursos que o proprietário do imóvel tinha direito, era necessária a emissão do "Termo de Aceitação Técnica da Obra" pela EMURB e pelo DPH.

Para os casos em que a obra não tivesse sido acompanhada pela empresa municipal essa dispunha de um regramento interno que solicitava ao proprietário a entrega de relatórios, declarações e notas fiscais comprovando as etapas, ou a conclusão, da obra e os gastos com ela efetuada. Com posse deste material a EMURB, enviava equipe técnica ao local para realizar a vistoria final e assim aprovar, ou não, a emissão do Termo de Aceitação desde que este também detivesse o aval do DPH.

Entretanto, ao realizar vistoria no local a equipe da EMURB constatou que as obras, já em sua fase final, estavam em desacordo com o projeto aprovado pelo Departamento do Patrimônio Histórico e solicitou que este realizasse vistoria urgente para atestar o fato. Em dezembro de 2003, o DPH manifestou parecer contrário à emissão do Termo de Aceitação Técnica da Obra, considerando que a execução das obras do Hotel Jaraguá não haviam sido realizadas conforme projeto aprovado pelo Departamento através do Processo 1999-0.020.116-7 (DPH, 1999).

Em seu parecer, o DPH informava que características externas e internas, objeto de preservação haviam sido modificadas ou removidas sem a autorização necessária. E, ainda, no mesmo parecer atentava para o fato de que o proprietário do imóvel tombado pleiteava naquele momento a isenção do Imposto Predial Territorial e Urbano (IPTU) ${ }^{169}$ e essa também fora indeferida devido as obras de modificação constatadas quando da vistoria ao local.

\footnotetext{
${ }^{169} \mathrm{~A}$ isenção de IPTU que trata o texto diz respeito ao benefício concedido no âmbito do ProCentro, projeto sobre o qual discorremos brevemente no capítulo 3 desta dissertação e que visava conceder isenção fiscal aos proprietários de imóveis tombados, num perímetro delimitado, que restaurassem ou preservassem a fachada de seus imóveis. (SÃO PAULO, 1997b).
} 
Neste ponto, já podemos discernir um dos problemas da TPC, ou de seu trâmite. Ao longo do texto intentamos demonstrar o desenrolar do procedimento necessário para obtenção do benefício e, como se já não bastassem os percalços que ocorreram devido aos prazos para andamento do processo, aliou-se a estes a questão da ADIn, paralisando por um período a tramitação da transferência. $E$, a isto podemos associar o costume ${ }^{170}$ que alguns empreendedores do setor da construção civil adquiriram ao longo dos anos de realizar construções sem aprovação da municipalidade se utilizando da justificativa que os procedimentos são longos e não acompanham o cronograma de obra.

Ora, entendemos que, primeiramente, para realização de uma obra deve-se obter as autorizações das instituições necessárias para então dar início a construção, seguindo fielmente o aprovado pela Prefeitura ou, na necessidade de alterações que esta seja comunicada, fato que entendemos não ter ocorrido no caso do Hotel Jaraguá. Portanto, com a negação do DPH sobre a emissão do Termo de Aceitação o benefício ficou sob custódia da EMURB aguardando a regularização da obra e aceite do órgão de preservação para sua liberação. Sendo assim o interessado protocolou novos processos, um no Departamento do Patrimônio Histórico versando sobre restauro e outro, na Secretaria de Habitação (SEHAB).

Cumpre atentar que o proprietário ao solicitar o benefício, o ressarcimento das obras, entregou comprovante de pagamento de um conjunto de elevadores e escadas rolantes para o edifício ${ }^{171}$. Entendemos a necessidade de tais itens para o funcionamento de um edifício do porte de um hotel, porém, somos da opinião que os mesmos não fazem parte do escopo de uma obra de restauro ainda mais no caso do Hotel Jaraguá, cuja preservação recai sobre elementos externos e internos específicos. Ou seja, o benefício da transferência de potencial construtivo não foi realizado para conservar ou restaurar o imóvel tombado, mas sim como instrumento de exceção a lei de uso e ocupação do solo para obtenção de parâmetros construtivos mais vantajosos.

\footnotetext{
170 Grifo da autora

171 O Grupo Técnico da Operação Urbana Centro entendeu que as despesas realizadas com a compra e das escadas rolantes e elevadores atenderam aos objetivos da restauração do edifício, porém aos realizar vistoria no local foi verificado que a implantação dos mesmos foi realizada em desacordo com o aprovado no processo. (EMURB, 1998b)
} 
Devendo aguardar a execução da obra da restauro assim como seu posterior ateste, no início do ano 2009 o interessado protocolou novo pedido de exceção a legislação e este se referia à Outorga Onerosa do Direito de Construir (OODC), conforme processo $2001-0.258 .377$ - 0. Mas, segundo o art. 211 do Plano Diretor Estratégico de 2002, o Hotel Jaraguá consta como pertencente a Zona de Preservação Cultural - Bens de Interesse Representativo (ZEPEC - BIR), logo, este não é passível de utilizar a OODC (SÃO PAULO, 2002).

O pedido de OODC foi separado do pedido de TPC transfigurando-se em um novo processo, o processo que trata da transferência encontrava-se no Departamento do Patrimônio Histórico, em novembro de 2017, aguardando análise da obra de restauro e modificação, para retorno a SPUrbanismo e prosseguimento no que se refere a emissão, ou não, do Termo de Aceitação Técnica da Obra.

\subsection{Mosteiro São Bento, dois momentos da OUC}

O atual conjunto que divide espaço com o Largo de São Bento, foi construído entre 1913 e 1922, com projeto do arquiteto alemão Richard Brendl (1875-1955), seguidor da escola artística de Beuron e, representante da tradição eclética alemã. $O$ interior foi idealizado pelo arquiteto belga Adelberto Gressnight, também é decorado seguindo o estilo beuroniano cujas características mais marcantes são a harmonia, a monumentalidade e os ornamentos com temas religiosos (ARRUDA, 2007).

O conjunto composto pela igreja, abadia e colégio, foi tombado em 1992, pelo CONPRESP através da Resolução oo37 - tombamento da Área do Vale do Anhangabaú (CONPRESP, 1992) -, classificado com nível de preservação NP-1, significando com isso que a arquitetura do edifício deve ser preservada tanto interna como externamente, sendo admitidos reparos, restauros e modificação de envasaduras, desde que aprovados pelos órgãos de preservação competentes. A construção também é protegida pelo CONDEPHAAT, como imóvel pertencente a área envoltória do sobrado da Rua Florência de Abreu, no 111, através da Resolução SC 43/80 (CONDEPHAAT, 1980). 


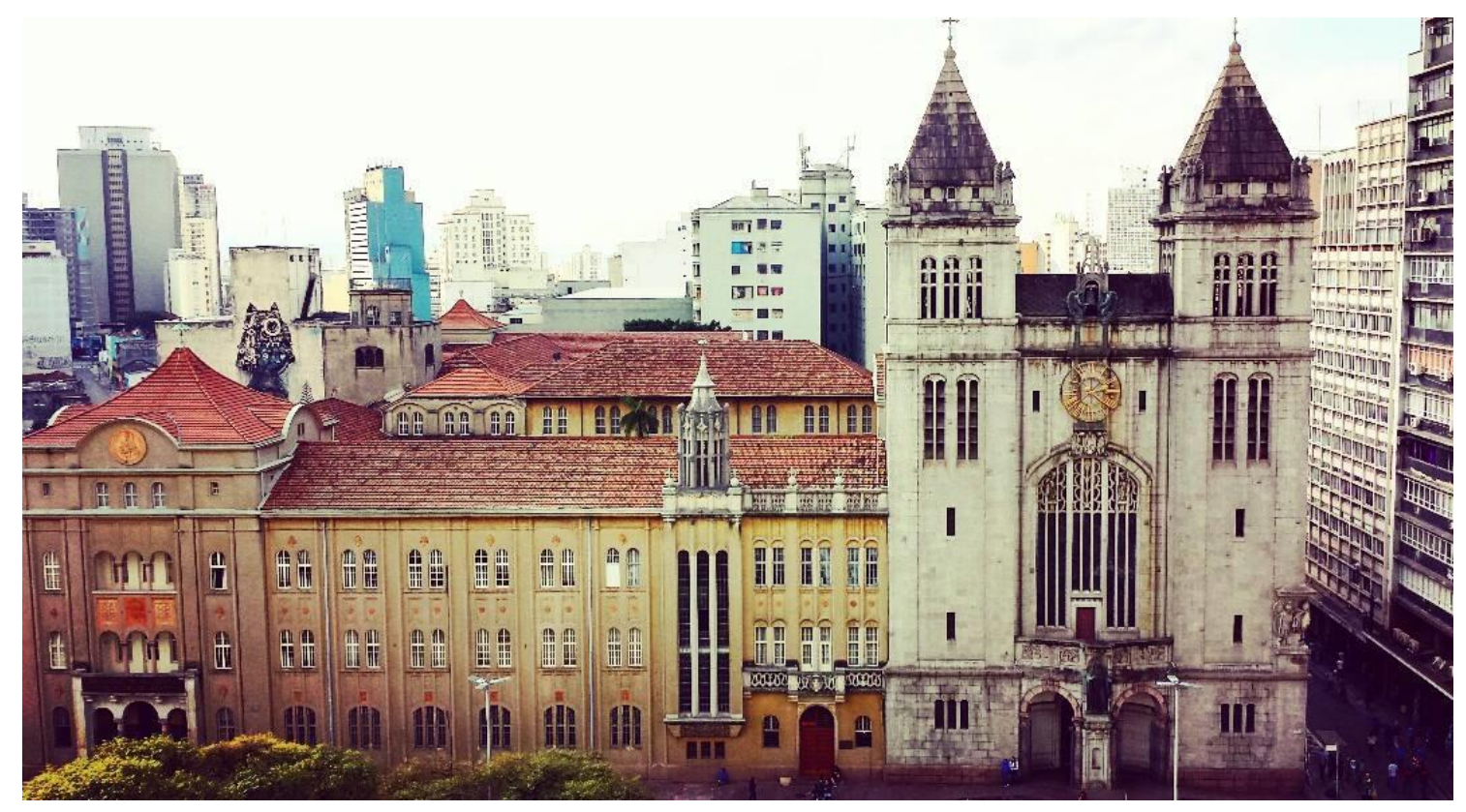

Figura 4.5 - Mosteiro São Bento. Fonte: a autora, 2016.

Em outubro de 1998, o representante do Mosteiro deu entrada na EMURB no pedido de participação na Operação Urbana Centro, apresentando projeto de restauro de pinturas e outros elementos e solicitando também a Transferência de Potencial Construtivo. Para tal fim, foram consideradas os lotes onde se localizam a Igreja e o Mosteiro São Bento, enquadrados à época como Z8.200-086, perfazendo uma área de $10.365,74 \mathrm{~m}^{2}$ (dez mil trezentos e sessenta e cinco vírgula setenta e quatro metros quadrados). Com coeficiente de aproveitamento igual a 2,54 (dois vírgula cinquenta e quatro) o imóvel poderia transferir $98.055,21 \mathrm{~m}^{2}$ considerando o disposto no Inciso I do artigo $7^{\circ}$ da Lei da Operação Urbana Centro que adotava para os casos onde 0 coeficiente de aproveitamento existente no lote fosse inferior a 7,5 (sete vírgula cinco) o valor máximo igual a 12 (doze).

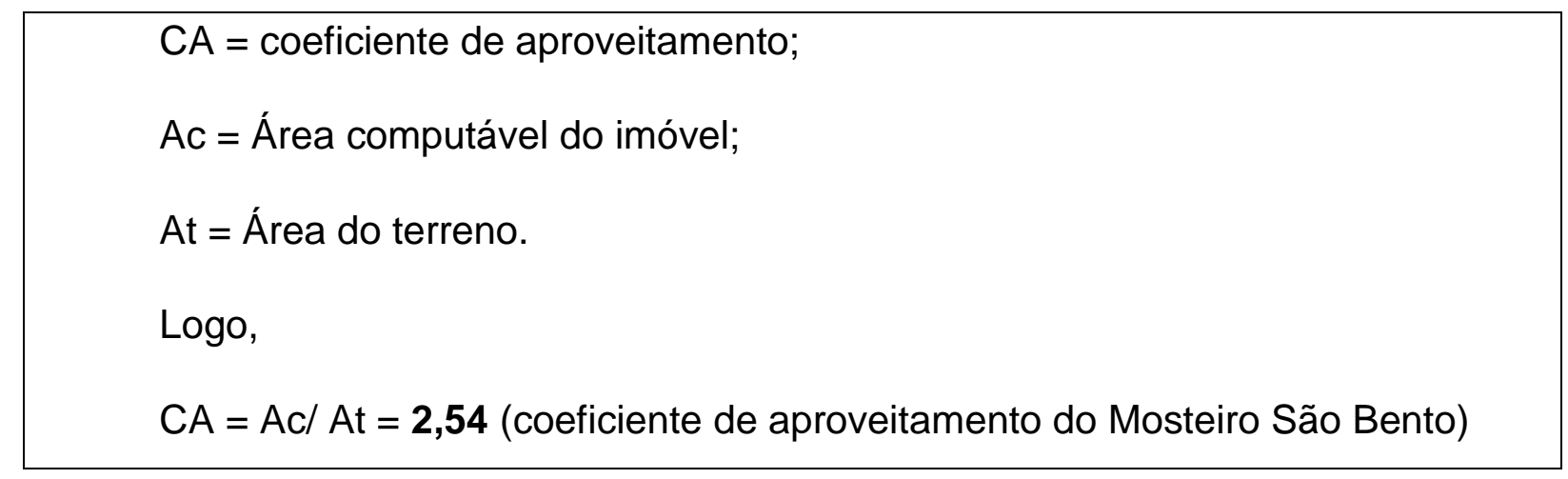


Um mês após o protocolamento do processo, foi emitida, e retirada, a Declaração de Potencial Construtivo para o Mosteiro São Bento. Assim, o processo foi enviado ao CONPRESP para análise do projeto de restauro e obtendo logo em seguida deliberação favorável as obras ali propostas. Com isso o processo retornou à EMURB para que fosse efetuada a análise do orçamento das obras de restauro. Contudo, somente neste momento foi observado que os lotes pertencentes ao Mosteiro haviam sido remembrados pela Prefeitura Municipal de São Paulo, sem consentimento comprovado do proprietário, inviabilizando a concessão dos benefícios disponibilizados pela Operação Urbana Centro.

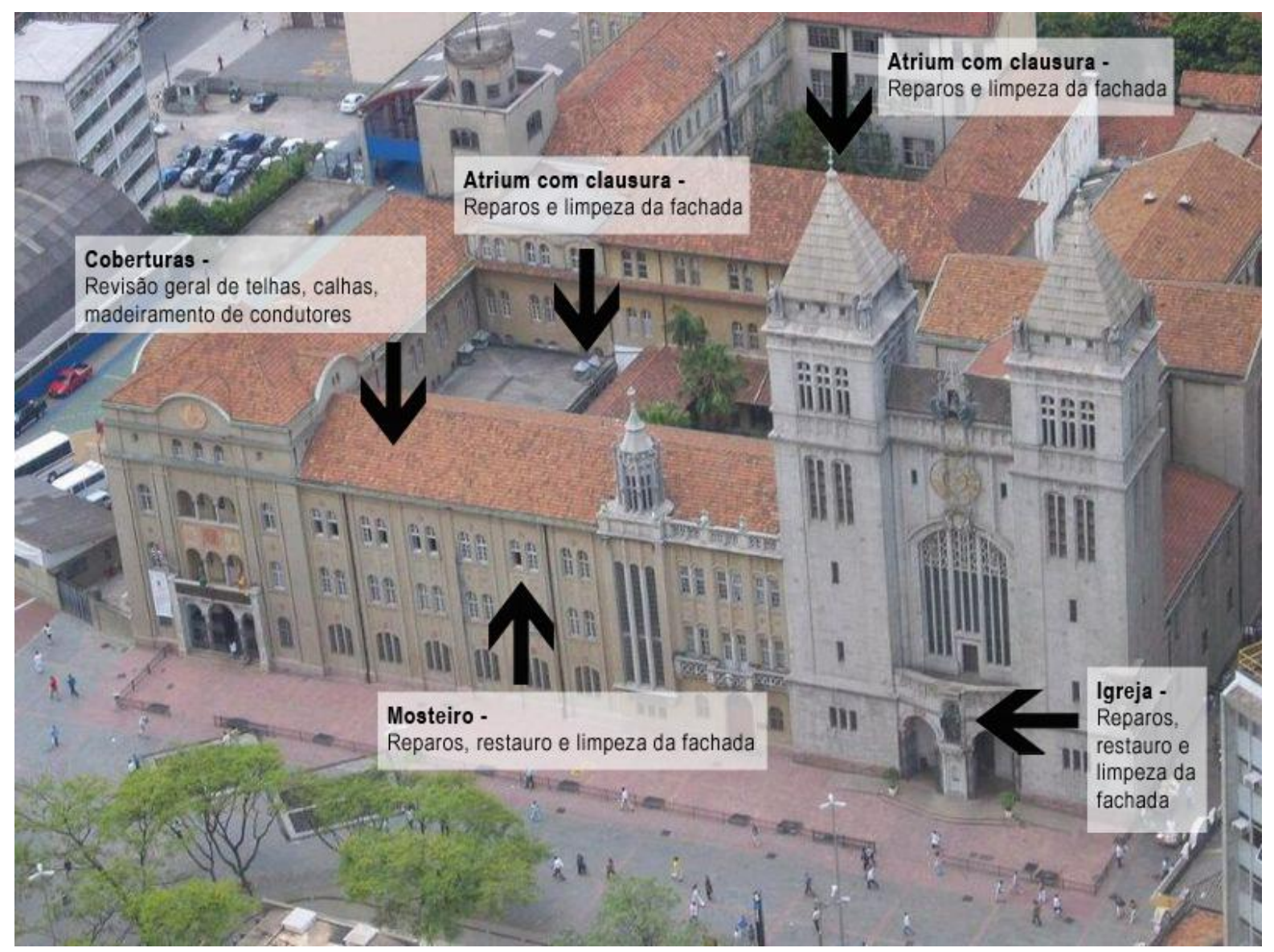

Figura 4.6 - Indicação dos locais onde seriam efetuadas as obras de restauro e conservação. Modificações da autora sobre imagem. Fonte: EMURB, 1998a; Wikimedia Commons,2017.

A Lei no 12.349/97 permitiu a concessão de incentivos aos imóveis enquadrados como Z8.200, porém ocorreu que, ao ser efetuado o remembramento dos lotes no caso do Mosteiro São Bento estes perderam sua característica de Z8.200 
pois foram juntados a um lote que não era objeto de preservação. Ou seja, neste caso a transferência seria realizada para um lote que não fazia parte da listagem de Z8.200, apesar dos outros dois constarem na mesma, sendo assim, não poderia transferir potencial construtivo.

Após os fatos acima relatados o cálculo foi refeito considerando um coeficiente de aproveitamento igual a 2,40 (dois vírgula quarenta), excluindo-se a área construída pertencente ao lote que não estava classificado como Z8.200 e, alcançando com isso o valor de 99.509,31 $\mathrm{m}^{2}$ (noventa e nove mil quinhentos e nove vírgula trinta e um metros quadrados) de potencial construtivo e obtendo um aumento de $1.454,10 \mathrm{~m}^{2}$ (um mil quatrocentos e cinquenta e quatro vírgula dez metros quadrados) em relação ao potencial anteriormente calculado. Ou seja, a redução do valor de área construída e do coeficiente de aproveitamento resultou no aumento de potencial passível de transferência (DOM, 1998)

Após a revisão dos índices foi emitida nova Declaração de Potencial Construtivo e solicitado ao interessado que fossem readequadas e reapresentadas as planilhas de orçamento da obra de restauro. Neste período foi imposta a Ação de Inconstitucionalidade promovida pelo Ministério Público Estadual e os processos de Transferência de Potencial Construtivo foram bloqueados por um certo tempo. Contudo, em 2001, após notificar ao proprietário que, mesmo com a imposição da ADIn os procedimentos de tramitação não estavam impedidos porém, não obtendo manifestação por parte deste, a EMURB arquivou o processo que viria a ser reativado somente em 2005.

Aproveitando a instituição do Plano Diretor, em $2002^{172}$ e da Lei de Parcelamento, Uso e Ocupação do Solo (LPUOS) em $2004^{173}$ a empresa municipal enviou comunicado ao responsável pelo Mosteiro São Bento questionando se este teria interesse em prosseguir com o processo de solicitação da TPC, já que a aprovação da LPUOS permitia reatar os procedimentos de transferência sem incorrer em prejuízo ao interessado.

Neste trecho da análise do processo, não ficou muito claro se o cessionário que apresentou proposta de compra de potencial o fez por intermédio da EMURB ou do

172 Lei no 13.430, de 13 de setembro de 2002. (SÃO PAULO, 2002)
173 Lei no 13.885, de 25 de 25 de agosto de 2004. (SÃO PAULO, 2004) 
Mosteiro São Bento. O que pudemos apreender é que este cessionário dispunha de um lote na Avenida Angélica e solicitou comprar potencial construtivo para poder empreender naquela região. A proposta foi negada pela empresa municipal pois, segundo esta, a implantação de estação do Metro - Linha Amarela naquela região, ainda não havia sido oficializada pela Companhia do Metropolitano de São Paulo, impossibilitando assim a TPC conforme estabelecido pela Lei de 2004 (SÃO PAULO, 2004) sem prejuízo do imposto pela ADIn. O interessado reiterou o pedido anexando ao processo planta de construção do Metro, como documento comprobatório das obras que ali iriam ser iniciadas e, com isso obteve parecer, EMURB, favorável à compra de potencial.

Porém, um parecer da Superintendência de Desenvolvimento Urbano negou a transferência se referendando no Inciso IV do art. $7^{\circ}$,

O coeficiente final do imóvel cessionário não poderá exceder a 4 (quatro) vezes a área do lote ou a 1,5 (uma e meia) vezes o coeficiente de aproveitamento máximo da zona de uso onde está localizado, prevalecendo o maior valor. (SÃO PAULO, 1997a)

Pois a proposta de compra de potencial construtivo adicional de $2.683,79 \mathrm{~m}^{2}$ (dois mil seiscentos e oitenta e três vírgula setenta e nove metros quadrados) realizada pelo cessionário, cujo CA básico do lote era de 2,5 (dois e meio) iria ultrapassar CA máximo 4 (quatro) da zona de uso em que seria empreendida a construção, Zona Mista (ZM) pela Lei no 13.885/04 (EMURB, 1998).

Se passaram treze anos para que uma nova proposta de compra de potencial construtivo do Mosteiro São Bento fosse protocolada novamente, e esta foi realizada conforme os novos parâmetros dispostos pela Norma de Procedimentos 59.00/2016 (SPURBANISMO, 2016). Considerando que os processos de transferência e de compra de potencial foram autuados antes da regulamentação da Norma, foi emitido um comunique-se para que os interessados complementassem os documentos anteriormente entregues.

Para realizar os procedimentos conforme a nova Norma de Regulamentação da SPUrbanismo o Mosteiro São Bento teve que autuar no DPH um processo contendo relatório fotográfico das obras de restauro realizadas entre 2011 e 2015 , plano de manutenção permanente do imóvel protegido abrangendo sua conservação 
e manutenção pelos próximos anos, entre outros documentos. Este trâmite foi necessário pois permitiu que o Departamento do Patrimônio Histórico analisasse o processo e emitisse o Atestado das Condições de Conservação e Preservação do imóvel enquadrado como ZEPEC-BIR para o proprietário, assinalando que a obra de restauro efetuada estava em consonância com as diretrizes impostas pelo órgão de preservação. E, com isso o cedente ficou autorizado a comercializar o potencial construtivo que lhe pertencia (EMURB, 2016).

Concomitante ao protocolo de processo no DPH o proprietário ou responsável pelo Mosteiro de São Bento autuou processo também na SPUrbanismo, contendo tanto os documentos do seu imóvel (cedente) quanto do imóvel cessionário, para análise do Grupo do Técnico de Trabalhos no que se referia ao impacto da implantação do empreendimento e, aos dados para realização do cálculo da Contrapartida Financeira.

\begin{tabular}{|c|c|}
\hline \multicolumn{2}{|r|}{ Dados Cedente } \\
\hline $\begin{array}{l}\text { Compromissário } \\
\text { cedente: }\end{array}$ & Mosteiro São Bento de São Paulo \\
\hline № Processo: & $1998-0.205 .296-5$ \\
\hline Endereço: & Largo de São Bento, s/nº. \\
\hline Zona de uso: & ZC \\
\hline Tombamento: & Resolução 37/ CONPRESP/ 92 \\
\hline \multicolumn{2}{|r|}{ Dados da Proposta } \\
\hline Área do terreno: & $10.365,74 \mathrm{~m}^{2}$ \\
\hline $\begin{array}{l}\text { Área construída } \\
\text { computável: }\end{array}$ & $26.333,67 \mathrm{~m}^{2}$ \\
\hline $\begin{array}{l}\text { Potencial construtivo } \\
\text { passível de } \\
\text { transferência: }\end{array}$ & $99.509,31 \mathrm{~m}^{1}$ \\
\hline $\begin{array}{l}\text { Potencial construtivo a } \\
\text { ser debitado do total da } \\
\text { Declaração } \\
\text { 0004/SEMPLA/98 }\end{array}$ & $8.107,06 \mathrm{~m}^{2}$ \\
\hline Solicitatação & $\begin{array}{l}\text { Transferência de Potencial Construtivo nos } \\
\text { termos do art. } 7^{0} \text { da Lei } n^{0} 12.349 / 96\end{array}$ \\
\hline
\end{tabular}

Quadro 4.13 - Dados do cedente. Tabulação da autora. Fonte: DOM, 2016. 


\begin{tabular}{|c|c|}
\hline \multicolumn{2}{|r|}{ Dados Cessionário } \\
\hline Compromissário cessionário: & JML CORP DESENVOLVIMENTO IMOBILIÁRIO LTDA \\
\hline № Processo: & $2016-0.232 .665-3$ \\
\hline Endereço: & $\begin{array}{l}\text { Rua José Maria Lisboa, } 745,753,757 \text { com Av. Nove } \\
\text { de Julho, } 3123,3127,3133\end{array}$ \\
\hline Zona de uso: & $\begin{array}{l}\text { antiga PI- ZM3b - } 16 \text { (Lei 13.885/2004) e Zona Eixo } \\
\text { de Estruturação Urbana - ZEU }\end{array}$ \\
\hline Solicitação: & $\begin{array}{l}\text { Área construída computável adiconal transferida de } \\
\text { imóvel tombado nos termos do art. } 7^{\circ} \text { da lei } n^{\circ} \\
\text { 12.349/97 }\end{array}$ \\
\hline \multicolumn{2}{|r|}{ Dados da Proposta } \\
\hline Tipo de obra: & Construção de uso misto \\
\hline Categoria da obra: & $R 2 v^{*}$ enR1** \\
\hline Área do terreno: & $2.236,68 \mathrm{~m}^{2}$ \\
\hline |Área construída computável: & $8.946,01 \mathrm{~m}^{2}$ \\
\hline Área a ser doada: & $104,30 \mathrm{~m}^{2}$ \\
\hline $\begin{array}{l}\text { Área construída adicional Aca } \\
\text { pleiteada pelo cessionário }\end{array}$ & $6.292,13 \mathrm{~m}^{2}$ \\
\hline Índices urbanísticos: & $\mathrm{CA}=3,9964 / \mathrm{T} . \mathrm{O}=69,92 \%$ \\
\hline
\end{tabular}

Quadro 4.14 - Dados do cessionário. Tabulação da autora. Fonte: Diário Oficial do Município, 2016.

Lembrando que o valor do PCpt disponível pelo imóvel cedente era de 99.509,31 $\mathrm{m}^{2}$ (noventa e nove mil quinhentos e nove vírgula trinta e um metros quadrados) e que este já havia realizado as obras de restauro, orçadas em 1998, no valor de aproximadamente $R \$ 7.700 .000,00$ (sete milhões e setecentos mil reais) descontado o custo de projeto e acompanhamento técnico, foi estabelecido pela Comissão Executiva como valor de Contrapartida Financeira o montante de R\$ 24.655.569,83 (vinte e quatro milhões seiscentos e cinquenta e cinco mil quinhentos e sessenta e nove reais e oitenta e três centavos) calculado a partir do Benefício (B) multiplicado pelo fator de desconto igual a 0,5 (zero vírgula cinco). Fator adotado para as propostas de relevante interesse urbanístico, que visam fomentar o desenvolvimento cultural e econômico da área central, mas é também, o menor dos fatores de desconto da tabela. Onde o maior fator, igual a 1 (um), reverteria um valor de Contrapartida Financeira da ordem de $\mathrm{R} \$ 49.311 .139,66$ (quarenta e nove milhões trezentos e onze mil e cento e trinta e nove reais e sessenta e seis centavos) para 0 Mosteiro São Bento (CTLU, 2017). 
Poderíamos pressupor que a adoção do menor fator de desconto teria sido realizada considerando o cálculo dos $5 \%$ (cinco por cento) do FUNDURB, conforme $\S 5^{\circ}$ do art. 24 da Lei 16.402/2016 onde se lê:

O valor pecuniário correspondente à totalidade do potencial construtivo transferido no período referente aos últimos doze meses em relação às transferências do direito de construir sem doação nos termos do art. 124 da Lei no 16.050, de 31 de julho de 2014 - PDE, não poderá exceder a 5\% (cinco por cento) do valor total arrecadado no FUNDURB no mesmo período, considerando a data do pedido da certidão de transferência de potencial construtivo (SÃO PAULO, 2016).

Pois o cessionário somente obteve a certidão em 2016, posterior a lei supracitada. Contudo em relatório da CTLU/2016 foi informado que este não era o caso do presente processo, já que o mesmo estaria dispensado de atender a norma estabelecida pela lei de 2016 considerando a informação nำ190/ 2016/SMDU, a qual não obtivemos acesso, que exclui da aplicação da lei 16.050/16 as Declarações ${ }^{174}$ expedidas antes da aprovação do Plano Diretor em 2014, que é o caso do Mosteiro São Bento.

Logo, podemos analisar a adoção do fator 0,5 (zero vírgula cinco) a diversas questões relacionadas ao Mosteiro São Bento, como por exemplo, o fato desta ser uma instituição religiosa e com isso dispor de isenção de IPTU algo que também se caracteriza como uma forma de incentivo podendo ser relacionada indiretamente à conservação do edifício. Ou se considerarmos que a obra de restauro já havia sido realizada, com doação de um benfeitor (ESTADO DE SÃO PAULO, 2011). De fato, o que podemos concluir é a subjetividade da aplicação deste fator de correção, cuja proposição foi delegada à Comissão Executiva sem que o proprietário do imóvel tombado tenha claramente a resposta para o valor disponibilizado como Contrapartida Financeira.

Com o estabelecimento do valor da contrapartida financeira, a aceitação da CTLU e posterior publicação da decisão no Diário Oficial do Município, o proprietário do Mosteiro São Bento, apresentando o Atestado emitido pelo DPH, assinou o Termo de Compromisso para Fins de Transferência do Potencial Construtivo e assim deu

${ }^{174}$ Grifo da autora 
prosseguimento a operação de venda do potencial. Entendemos que, mesmo com a realização da Transferência sendo feita diretamente entre as partes interessadas, estas ainda deverão aguardar o aceite dos órgãos municipais para efetuar a transação monetária.

No caso aqui estudado pudemos verificar, mais uma vez, o longo período necessário para obtenção da transferência de potencial construtivo. Mais uma vez, o proprietário teve que realizar a obra de restauro apartada da concessão do benefício buscando apoio de um doador externo para o pagamento da obra. Entendemos que no caso do Mosteiro São Bento se o processo de transferência tivesse sido mais ágil o valor de contrapartida recebida iria contribuir como pagamento das obras de conservação do patrimônio, mas para isso teria sido necessário que o mesmo já dispusesse de um comprador no momento da emissão da declaração de potencial, o que não ocorreu.

Com a aprovação da NP-SPUrbanismo, em 2016 (SPURBANISMO, 2016), o sistema foi alterado, ficando o cedente responsável por efetuar todo o procedimento concernente a transferência. A Norma também foi responsável por deixar a cargo do órgão de preservação o ateste final para a disponibilização do valor da contrapartida, pois, como vimos, somente com o Termo de Compromisso para Fins de Transferência do Potencial Construtivo em mãos o proprietário estará apto a realizar a transação. A eficiência pode ser comprovada no caso aqui estudado, Mosteiro São Bento o primeiro imóvel protegido a realizar a transferência de acordo com o novo procedimento. Entendemos que o método foi eficaz no quesito agilidade, visto que, ainda em dezembro de 2017, o proprietário do imóvel realizou mais uma negociação de transferência.

Através da análise realizada, neste capítulo, pudemos observar 0 funcionamento do instrumento da TPC. Verificamos que os procedimentos no caso do proprietário de imóvel tombado eram mais longos e demandavam um dispêndio monetário maior e, mesmo assim, a procura por cessão de potencial nos primeiros anos da operacionalização da TPC foram maiores do que a procura por compra, isto mostra o interesse e necessidade dos proprietários de bens tombados em obter 0 incentivo. Observamos ainda que, o mecanismo da transferência de potencial construtivo através de sua fórmula de cálculo privilegiava o incorporador imobiliário 
promovendo para este a possibilidade de construir acima do limite permitido pela legislação de zoneamento a baixo custo, pois, como vimos, nos procedimentos efetuados de transferência quatro dos seis casos realizaram empreendimentos em uma zona cujos valores do metro quadrado estavam muito abaixo daquele praticado na área central traduzindo-se em ganho para o incorporador.

Entendemos que em 2016, quando a empresa municipal revisou a Norma de Procedimentos, a TPC foi readequada à finalidade primeira de sua implementação, que era promover a conservação do imóvel protegido. Com o estabelecimento da Resolução CONPRESP 23/2015 (CONPRESP, 2015) os proprietários de imóveis tombados na área central, e no restante do município, passaram a ter mais obrigações, porém também foram contemplados com um alargamento do alcance da TPC, pois a partir daquele momento o instrumento passou a contemplar todo o escopo necessário para uma obra de restauro sendo permitida a utilização da contrapartida financeira nos casos de elaboração de projeto.

Pudemos observar os avanços impostos pela revisão da Norma quando analisamos o caso do Mosteiro São Bento, que teve seu processo de transferência finalizado em 2017, vinte anos após a obtenção da Declaração de Potencial Construtivo, e realizou em um mesmo ano duas vezes a venda de potencial pois agora o proprietário do imóvel tombado é o responsável por dar entrada nos processos e também por realizar os trâmites necessários para a transferência junto ao interessado (cessionário). Ainda é recente a aprovação da NP para que possamos avaliar se ela irá contribuir com a conservação do patrimônio na área central da cidade mas somos do entendimento que em relação ao sistema anterior esta já é um avanço. 


\section{CONCLUSÃO}

O objeto de estudo desta pesquisa foi o instrumento da Transferência de Potencial Construtivo (TPC), tendo como abrangência de análise, a concepção e evolução deste instrumento, desde 1975 até 2016, utilizado para promover a preservação e conservação do patrimônio cultural na área central da cidade de São Paulo. Ao princípio deste estudo verificamos a relação do instrumento Solo Criado, conceito do qual nasceu a TPC, com instrumentos internacionais de regulação do uso do solo. Por isso, iniciamos o trabalho remontando a formulação da política de preservação francesa, norte-americana e brasileira, procurando demonstrar as diferenças na tomada de decisão para instituição de uma política pública voltada a preservação e, nos dois casos internacionais, valorização do patrimônio cultural.

Explorando a concepção das políticas de preservação na França e nos E.U.A., pudemos verificar que nestes dois países a proteção dos bens culturais nasceu aliada ao pensamento econômico, no sentido de prospectar fundos e ações para que as gerações futuras possam usufruir do bem objeto de preservação. Observamos também que em ambos os casos foi realizado um inventário geral do patrimônio da nação para que assim fosse possível estabelecer formas de incentivo visando sua conservação. Apesar dos dois países terem formas de abordagem diferentes quanto a responsabilidade sobre o patrimônio cultural nos níveis de governo, apreendemos que a preservação do patrimônio, nos dois exemplos estudados, nasceu conjugada com o pensamento de que é preciso enxergar o patrimônio cultural do ponto de vista econômico, pois sem esse direcionamento, ficamos somente no estágio do proteger para o momento presente sem pensar as consequências, e gastos futuros, que o ato da preservação vem a gerar.

Ao analisarmos a formulação da política de preservação francesa, norteamericana e brasileira, verificamos que no caso do nosso país, o ato de preservar nasceu de uma visão política e artística. Política quando se instituiu a preservação de alguns monumentos objetivando fomentar o ideal de nação, através da eleição de um conjunto de bens, que um pequeno grupo desejava estabelecer. E dizemos que a visão também foi artística considerando a promoção de bens a patrimônio cultural sem avaliar o empreendimento necessário para manter aqueles bens íntegros no futuro, 
preservou-se pela beleza e distinção e não para resguardar aquele elemento para as gerações posteriores, pois, do contrário ter-se-ia elaborado métodos para manter o bem cultural ao longo dos anos.

Ainda sobre a política de preservação, estudamos a elaboração do Departamento do Patrimônio Histórico de São Paulo bem como das primeiras manifestações que buscaram proteger os bens de interesse histórico e cultural do município. Por meio dessa análise pudemos verificar que a preservação no âmbito do órgão preservacionista nasceu seguindo o modelo nacional no que se refere aos dois pontos discutidos acima, sem conexão com a questão econômica, ou seja, sem elaborar uma política que almejasse prover a proteção dos bens dispondo de incentivos e benefícios. Mesmo no caso dos imóveis públicos protegidos verificamos que a destinação de verba era irrisória nunca suficiente para conservar os edifícios. Enquanto o outro órgão, EMURB, que pretendeu salvaguardar uma lista de imóveis previu a necessidade de destinar incentivos para a valorização dos bens, trabalhando com o binômio preservar e valorizar. E por mais que a princípio não tenha sido instituído um mecanismo que promovesse incentivos para a preservação do patrimônio, a característica que destacamos foi o interesse em avançar além do primeiro estágio, que era o da proteção, algo que não constamos através dessa pesquisa com o órgão de preservação.

O entendimento dos primórdios da preservação se fez necessário para que pudéssemos compreender como se deu a implementação dos dois instrumentos: Plafond Légal de Densité (PLD) e Space Adrift, modelos para a formulação da Transferência de Potencial Construtivo. Pois concebemos que parte da desvalorização do patrimônio cultural brasileiro advém daquele primeiro momento quando não se pensou, ou não se quis pensar, no que seria necessário para manter os bens nos anos futuros. Foi neste sentido, ainda considerando a influência de ações passadas na formulação de políticas de preservação que reverberam nos modelos futuros de incentivos e benefícios a conservação que realizamos análise de projetos e planos internacionais, na França e nos EUA, buscando demonstrar como é realizada a gestão dos bens protegidos e quais mecanismos são utilizados para fomentar a conservação e valorização do patrimônio cultural edificado. 
Sem esquecer as diferenças entre os sistemas administrativos legais daqueles dois países, observamos que no caso francês o Estado, através do órgão competente em matéria de patrimônio cultural, promove planos direcionados exclusivamente a preservação dos bens de interesse cultural mas que estes compartilham, também, de incentivos financeiros disponibilizados por agências federais e departamentos relacionados a questões urbanas e arquitetônicas que não são exclusivamente voltados ao patrimônio cultural edificado, ou seja, existe um aporte considerável de proventos viabilizados para a conservação do patrimônio e estes, algumas vezes, podem ser justapostos àqueles disponibilizados pelo órgão de preservação francês. Já nos E.U.A., o governo federal também disponibiliza incentivos aos proprietários de imóveis tombados, desde que seus imóveis façam parte do plano estadual de preservação do patrimônio, seja ele tombado ou somente listado. Os proprietários contam ainda com verbas disponibilizadas pelas associações e ONGs de preservação de patrimônio cultural, concebidas por interessados em promover a valorização e conservação dos bens protegidos.

Com a análise realizada no Capítulo II verificamos que ambos os países trabalharam formas dissociadas de preservar e conservar o patrimônio, enquanto na França o Estado é centralizador nos EUA as ações são delegadas ao nível mais local. Considerando a brevidade do estudo não foi possível avaliar qual dos métodos promove melhores frutos a valorização patrimônio histórico, contudo pudemos compreender que a implementação de planos e projetos nasceu com o enfoque que cada país adotou quando da formulação de sua política patrimonial. O que demonstra a ingenuidade ao se utilizar como base para formulação de um instrumento de incentivo à preservação do patrimônio paulistano dois instrumentos formulados em contextos díspares do nosso.

Apesar do Solo Criado ter nascido no mesmo contexto que o PLD e o Space Adrift, num período em que os países buscavam meios de controlar o uso do solo, a formatação do mecanismo brasileiro ao se embasar nos modelos internacionais desconsiderou que em ambos os casos estes não eram os únicos incentivos oferecidos aos proprietários de imóveis tombados. E, também, que ainda não havia margem para avaliar a efetividade dos instrumentos, coisa que pudemos observar o contrário aqui em nosso estudo, visto que o PLD foi revogado e o Space Adrift jamais foi implantado em Chicago, em decorrência da simultaneidade dos estudos. 
No início do nosso trabalho entendíamos que a TPC havia nascido com base no Solo Criado, mas ao longo do estudo pudemos perceber, que estes dois instrumentos são desvinculados quando da implantação na cidade de São Paulo. Enquanto no Solo Criado a Transferência de Direito de Construir (TDC) seria viabilizada para o patrimônio cultural, infraestrutura urbana e áreas verdes, a TPC, nos estudos realizados pela EMURB-COGEP, é formatada exclusivamente para a preservação do patrimônio. Ela nasce, por assim dizer, como um instrumento que seria viabilizado para compensar os proprietários de imóveis tombados do ônus imposto pelo tombamento e para promover a conservação dos imóveis protegidos. Contudo, no meio do processo, os trabalhos foram paralisados e prosseguiu-se com o estudo do Solo Criado, que, ao nosso entendimento seria mais rentável para a municipalidade.

E assim, em 1984, a Transferência de Potencial Construtivo entra em pauta, na tentativa de dirimir o impacto das ações de salvaguarda o governo municipal propõe este instrumento como incentivo a conservação dos imóveis tombados, contudo, sem obter sucesso. Em 1992 a TPC é novamente proposta como incentivo à preservação do patrimônio cultural, passando a estar atrelada a Operação Urbana Anhangabaú em cujo perímetro ela estaria disponível aos proprietários de imóveis tombados. Porém, ocorreu somente um caso de transferência e este no mesmo lote do proprietário, sendo assim, mais uma vez o instrumento não pode ser avaliado. Três anos mais com a finalização do prazo proposto para a Operação Anhangabaú é instituída a Operação Urbana Centro.

A análise do instrumento da TPC na Operação Urbana Centro demonstrou que este, estabelecido com vistas a promover a valorização e conservação do patrimônio, atendia mais aos interesses da incorporação imobiliária que dos proprietários de imóveis protegidos. O método utilizado até 2016 privilegiava o empreendimento receptor, ou cessionário, ao disponibilizar a transferência para fora do perímetro, na maioria dos casos aprovados, para uma zona onde o coeficiente de aproveitamento era muito inferior em relação ao permitido pela Lei da OUC, o que se traduzia em ganhos para o empreendedor. Em segundo lugar, ainda considerando a diferença de características por zonas, ao considerar os valores venais para cálculo da contrapartida financeira, privilegiando assim empreendimentos em locais onde os valores venais seriam menores que no centro da cidade. 
Na Operação Urbana Centro, a TPC foi instituída como um instrumento que busca promover a conservação do bem protegido, mas podemos verificar através de nossos estudos de caso que o pressuposto não se realizou. Por influência de questões operacionais e de demanda, os proprietários dos imóveis tombados não conseguiram realizar o restauro do imóvel com o valor advindo da contrapartida financeira. As duas obras estudadas foram realizadas com fundos disponíveis pelo próprio proprietário ou doados por um benfeitor. Entendemos que a Transferência de Potencial Construtivo, antes de 2016, contribuiu com a preservação do patrimônio cultural edificado e não para a conservação. Ela contribuiu com a preservação ao propor a transferência do potencial que o proprietário do bem não poderia utilizar, logo, preservava-se as características de volume do imóvel. Agora, pelo nosso entendimento, para contribuir na conservação do imóvel o instrumento deveria prover meios para o proprietário pagar o projeto e a obra de restauro em seu período de duração e não por compensação como aconteceu nos casos aqui estudados.

Com a revisão da Norma de Procedimentos em 2016, pudemos avaliar brevemente, no caso do Mosteiro São Bento e pelo estudo da Resolução emitida pelo DPH, como favorável o novo método para obtenção da TPC. Já que agora o proprietário que não tem condições de arcar com os custos do projeto de restauro, pode solicitar a transferência, desde que assine um Termo, para efetuar o pagamento do trabalho. Na verdade, dizemos que é favorável quando na realidade o instrumento só passa a cumprir o que deveria ter sido feito durante estes vinte anos, que é prover o proprietário de imóvel tombado com recursos para a conservação do bem. Outro aspecto que consideramos relevante na nova regulamentação, é a agilidade que este provocou na apuração do processo documental ao repassar os trâmites da transação do instrumento para a órbita do contribuinte, excluindo a empresa municipal. Com a instituição da NP 59.00 (SPURBANISMO, 2016) o mecanismo da TPC passa a promover a preservação e, agora a conservação também, do patrimônio cultural edificado. Contudo pensamos que para uma contribuição na esfera urbana o instrumento ainda precisa de retificação, mas que isso somente será possível com a revisão da Lei da Operação Urbana Centro.

Deste modo, este trabalho conclui que a Transferência de Potencial Construtivo foi instituída privilegiando os incorporadores imobiliários utilizando para isso a figura do patrimônio cultural edificado. Da maneira como esta havia sido formulada em 1997, 
os proprietários de imóveis tombados dispunham do incentivo, mas ficavam limitados a efetivação da obra para posterior ressarcimento, o que significava que estes deveriam ter o dinheiro em caixa para poder efetuar o trabalho, e, então, receberem a contrapartida financeira disponibilizada com a venda do potencial. Pensamos que a NR 59.00 representa um ajuste que poderá vir a contribuir com a conservação dos imóveis inseridos no perímetro da O.U. Centro. Contudo entendemos que o Brasil, no nosso caso, mais especificamente São Paulo, detém ainda de um longo percurso no caminho para a valorização do patrimônio cultural através da concessão de incentivos fiscais.

E, para finalizar, dada a importância do assunto, torna-se necessário um exame minucioso do emprego efetuado, pelos proprietários de bens tombados cujas obras haviam sido realizadas antes da obtenção do incentivo, com o valor da transferência de potencial construtivo. Assim como seria interessante que se pesquisasse o motivo pelo qual, num montante de aproximadamente 600 imóveis protegidos na área central de São Paulo, somente dez por cento dos imóveis realizaram a transferência. E, ainda, pretendendo-se avaliar a fundo a questão da destinação de recursos para conservação do patrimônio cultural brasileiro sugerimos que seja realizado estudo acerca do provimento de verba realizado pelos governos, federais, estaduais e/ou municipais para manutenção dos imóveis de interesse histórico. 


\section{REFERÊNCIAS BIBLIOGRÁFICAS}

ABRAHÃO, S. L. Espaço público: do urbano ao público. São Paulo: Anablume, 2009.

ACTES DU SEMINAIRE DE CHINON. Les Secteurs Sauvegardés, ZPPAUP et PLU patrimoniaux. Chinon : Ministère de la Culture et de la Communication, 2007.

ANDRADE, R.M.F. O Patrimônio Histórico e Artístico e a Missão da Universidade. Rev. Pat. Hist. Art. Nac., n. 31. Rio de Janeiro, 2005.

ALOCHIO, L. H. A. O direito do urbanismo e a transferência do direito de construir: requisitos de limitação nas leis locais. Rev. Dir. Adm., vol. 249. Rio de Janeiro: FGVRJ; Editora Forum, 2008)

ALVAREZ, C.; CAMPOS, C.M. Um ícone reaproveitado: O Hotel Jaraguá em São Paulo. In: VII Seminário DoCoMoMo Brasil, 2007, Porto Alegre. Anais do VII Seminário DoCoMoMo Brasil, 2007. v. 1. p. 1-20.

ARRUDA, V. Tradição e Renovação: A arquitetura dos mosteiros beneditinos contemporâneos no Brasil. 2007. São Paulo: Dissertação (Mestrado em????) Faculdade de Arquitetura e Urbanismo, Universidade de São Paulo, São Paulo, 2007. AUDUC, A. Quand les monuments construisaient la nation: le service des monuments historiques de 1830 à 1940. France: La Documentation Française, 2008.

AVC. Associação Viva o Centro. São Paulo centro XXI, entre história e projeto. São Paulo, 1994.

BACKER, F. M. Development Rights Transfer and Landmarks Preservation Providing a Sense of Orientation. Journal of Urban and Contemporary Law, Vol 9, Lewis and Clark Law School, EUA, Portland, 1975.

BARNETT, J. Urban design as a public policy: pratical methods for improving cities. U.S.A : Architectural Record Books, 1974

BERGEL, J.L. Vente d'immeuble à rénover: contrat, intervenants, régime fiscal. França: Lamy, 2010. 
BORDAS, E; FONYI, A.; GARNIER, P.; REBOUL, Y.. Merimée et les monuments históriques. França: Presses Universitaires Mirai, 2005.

BOUZELY, J. C. Les zones de protection du patrimoine architectural et urbain. Paris: Revue Administrative, 1986.

BOYTON, B. The Interstate Highway System. New Hampshire Highways, 2004.

BRASIL, A.B. A ineficácia das ZEIS: um problema de legislação ou uma questão politíco-social? O caso de Fortaleza. 2016. Tese (Doutorado em Habitat) Faculdade de Arquitetura e Urbanismo, Universidade de São Paulo, São Paulo, 2016. CALIL, C.A.; PENTEADO, F. R. Me esqueci completamente de mim, sou um departamento de cultura. São Paulo: Imprensa Oficial, 2015.

CARDOSO, A. L.; RIBEIRO, L.C.Q. Reforma Urbana e Gestão Democrática: promessas e desafios do Estatuto da Cidade. Rio de Janeiro: Revan, 2012.

CASTILHO, A. L. H.; VARGAS, H.C.(Orgs.). Intervenções em centros urbanos objetivos, estratégias e resultados. São Paulo: Manole, 2015.

CASTRO, L. G, R. Operações urbanas em São Paulo: interesse público ou construção especulativa do lugar. 2007. Tese. (Doutorado em Planejamento Urbano e Regional) - Faculdade de Arquitetura e Urbanismo. São Paulo: Universidade de São Paulo, 2007.

CHAVES, J.; GILIOLI, R.; NEVES, C. Políticas culturais no Brasil e na França: elementos para uma análise comparada. Brasília: Câmara dos Deputados, 2015.

CHOAY, F. A alegoria do patrimônio. São Paulo: Estação Liberdade, 2006.

. O patrimônio em questão: antologia para um combate. São Paulo: Fino traço editora, 2011.

CHUVA, M.R.R. Os arquitetos da memória. Sociogênese das práticas de preservação do patrimônio cultural no Brasil (anos 1930 - 1940). Rio de Janeiro: Editora UFRJ, 2009.

- Por uma história da noção de patrimônio cultural no Brasil. Revista do Patrimônio Histórico e Artístico Nacional, nํ34. Brasília, 2012. 
CHUVA, M.R.R; NOGUEIRA, A.G.R. Patrimônio Cultural: políticas e perspectivas de preservação no Brasil. Rio de Janeiro: Editora: Mauadx, 2012

CIPRIANO, D.S. A Transferência do Direto de Construir: Benefício aos proprietários de imóveis tombados? Trabalho de conclusão de disciplina AUP840. São Paulo, 2016. Disponível em: http://www.fau.usp.br/docentes/depprojeto/ c_deak Acesso em: 05 out. 2016

CJ ARQUITETURA. O anteprojeto da lei de desenvolvimento urbano - Revista de Arquitetura Planejamento e Construção. no 16. São Paulo, 1977.

CONDIT, C. W. Chicago school of architecture : a history of comercial and public building in the in the Chicago Area, 1875-1925. Chicago : University Of Chicago Press, 1998.

CONJUR. Ministro garante continuidade de revitalização do Centro de SP. Consultor Jurídico. 06 de abril de 2004. Disponível em: www.conjur.com.br Acessado em: 06.jan. 2018.

COSTONIS, J. Space Adrift : Saving Urban Landmarks Through the Chicago Plan. Illinois : University of Illinois, 1975.

CULLINGWORTH, B; DAVOUDI, S.; et al. Town and Country Planning in the UK. Inglaterra: Routledge, 2014.

CYMBALISTA, R. Estatuto da Cidade: guia para implementação pelos municípios e cidadãos. São Paulo: Instituo Polis, 2001.

DALEFFE, A. Solo criado e a disciplina urbanística da propriedade. In: Rev Inf, Leg. v. 34, n. 135,1997

DÉAK, C.; SCHIFFER, S.R. O processo de urbanização no Brasil. São Paulo: EDUSP, 2015.

DI PIETRO, M.Z.Z.. Direito Administrativo. Rio de Janeiro: Editora Forense, 2016.

ESTADO DE SÃO PAULO, O (a). Definido, Solo Criado agora vai a SEPLAN. 16 de abril de 1977, página 16. Disponível em: http://sao-paulo.estadao.com.br Acesso em: jan. 2017. 
ESTADO DE SÃO PAULO, O. Audiência de projeto de requalificação do Anhangabaú é adiada. 31 de julho 2015, online. Disponível em: http://saopaulo.estadao.com.br Acesso em: 10. dez. 2017.

ESTADO DE SÃO PAULO, O. PIB cresce 5,2\% em 2004, o melhor desempenho desde 1994, diz IBGE. Caderno: Mercado. 01 de março de 2005, online. Disponível em: http://sao-paulo.estadao.com.br Acesso em: 10. dez. 2017.

ESTADO DE SÃO PAULO, O. Mosteiro de São Bento restaura basílica centenária, São Paulo, 05 de julho de 2011, online. Disponível em: http://saopaulo.estadao.com.br Acesso em: maio. 2017.

FAUSTO, B. História do Brasil. São Paulo: EDUSP, 2003.

FINLEY, D. E. The History of the National Trust for Historic Preservation (19471963). Washington, DC: National Trust for Historic Preservation, 1965.

FOLHA DE SÃO PAULO. PIB cresce 5,2\% em 2004, o melhor desempenho desde 1994, diz IBGE, Mercado, 01 de março de 2005, online. Disponível em: https://www1.folha.uol.com.br Acessado em: 11. Set. 2017.

FOWLER, J. M. Federal Historic Preservation Law: National Historic Preservation Act, Executive Order 11593, and Other Recent Developments in Federal Law. Washington, DC,1976.

FRANÇA. L'inventaire general des monuments et des richesses artistiques de la France. France : Ministère des Affaires Culturelles, 2009.

FRANÇA. Le Moniteur Parisien, 18 du octobre du 1830. Disponível em: http://gallica.bnf.fr Acessado em: 05.jul. 2017

FRANÇA. Sites classés et sites inscrits. Ministère de la Culture, 2017. Disponível em http://www.culturecommunication.gouv.fr Acesso em 24 ago. 2017

FURTADO, F.; JORGENSEN JR, P.; OLIVEIRA, M.T.; REZENDE, V. F. Revisão Bibliográfica comentada dos fundamentos da Outorga Onerosa do Direito de Construir - OODC. In: Rev. Dir. Cidade, Rio de Janeiro: UERJ, 2011. 
GEOSAMPA. Mapa Digital da cidade de São Paulo, 2017. Disponível em: http://geosampa.prefeitura.sp.gov.br Acesso em 12 dez. 2017.

GIGOT, M. Les zones de protection du patrimoine architectural, urbain et paysager (ZPPAUP), une forme de gouvernance patrimoniale? França: Culture and local Governance, 2008.

GILLI, J.P. Redéfinir le droit de propriété. França: Centre de recherches d'urbanisme, 1975.

GIOVANNONI, G.. Vecchie città ed edilizia nuova. Nuova Antologia, XLVIII, 1913.

GORTE, R. W. Proposals to Merge the Forest Service and the Bureau of Land Management: Issues and Approaches. Estados Unidos da América: Congressional Research Service, 2008.

GOUVEIA, M.A.; MICELI, S. Política cultural comparada. Rio de Janeiro: FUNARTE, 1985.

GRANELLE, J.J. As experiências da política fundiária na França. Rio de Janeiro: IBAM, 1981.

GRAVEREAU, S.G. Art et activisme dans le quartier parisien de Belleville. In: L'Information géographique, vol. 76. France : 2012.

GRAY, O. S. The response of federal legislation to historic preservation. Legal techniques in historic preservation, selected from papers for the Conference on Legal Techniques in Preservation. Washington D.C.: National Trust for Historic Preservation, 1971.

GREFFE, X. La Trace Et Le Rhizome - Les Mises En Scène Du Patrimoine Culturel. France: Presses De L'Université Du Québec, 2014.

HECK, E. Entrevista concedida à autora. São Paulo, 2017.

IBANEZ, M. P. Définition et régime juridique de passation des conventions de zone d'aménagement concerté. 1998. Mémoire (D.E.A. Droit Immobilier Prive et Public) - Faculté de Droit et de Science politique d'Aix-en-Provence, Universite D'aix Marseille III, Marseille,1998. 
JEGOUZO, Y. La fiscalité de l'amenagément: etat des lieux et questions prealables a une reforme. Groupement de recherche sur les institutions et le droit de l'aménagement, de l'urbanisme et de l'habitat - GRIDAUH. França, 2009

JOSÉ, B. K. Políticas Culturais e Negócios Urbanos: a instrumentalização da Cultura na Revitalização do Centro de São Paulo 1975-2000. São Paulo: Annablume, 2009.

KUHL, B. M. (org.). Gustavo Giovannoni: Textos escolhidos. São Paulo: Ateliê Editorial, 2013.

LAURENT, X. Grandeur et misère du patrimoine - d'André Malraux à Jacques Duhamel (1959-1973). France: La Documentation Française, 2003.

Naissance et développement de l'Inventaire. França: Revue littéraire et électronique de <www.malraux.org>, 2016.

LEACH, R. H. The Federal Urban Renewal Program: a ten-year critique. Law and Contemporary problems. Durham: Duke University Law Journal, 1960.

LE BAYON, S; LEVASSEUR, S. ; RIFFLART, C.. Ville et Logement. In : Revue de I'OFCE / Débats et politiques. França, 2013.

LEMOS, C. Arquitetura Brasileira. São Paulo: Editora Melhoramentos, 1979.

LIGIBEL, T. J.; TYLER, I. R.; TYLER, N. Historic Preservation: An Introduction to Its History, Principles, and Practice. New York: W. W. Norton \& Company, 2000.

LEFÈVRE, J.E.A. Entrevista concedida à autora em janeiro de 2018, São Paulo, 2018.

Operação Urbana Anhangabaú. In: Empresa Municipal de Urbanização EMURB. São Paulo: 1990.

MALERONKA, C. Projeto e gestão na metrópole contemporânea: um estudo sobre as potencialidades do instrumento 'operação urbana consorciada' à luz da experiência paulistana. 2010. Tese (Doutorado em História e Fundamentos da Arquitetura e do Urbanismo) - Faculdade de Arquitetura e Urbanismo, Universidade de São Paulo, São Paulo, 2010. 
MARCHI, L. Z. CIAM 8 - The Heart of the City as the symbolical resilience of the city. In: HEIN, C. (ed.) International Planning History Society Proceedings, 17th IPHS Conference, History-Urbanism-Resilience. Holland: TU Delft Open, 2016.

MARICATO, E.; WHITAKER, J.S. Operação Urbana Consorciada: diversificação urbanística participativa ou aprofundamento da desigualdade? In: OSÓRIO, L. (org.) Estatuto da Cidade e reforma urbana: novas perspectivas para as cidades brasileiras. Porto Alegre: Sérgio Antônio Fabris, p. 215-250

MARIUZZO, P. Tombamento não é sinônimo de prejuízo. Patrimônio - Revista eletrônica do IPHAN. Brasília, 2005.

MAYUMI, L. Entrevista realizada com Murilo Marx. São Paulo: Departamento do Patrimônio Histórico, 2005.

_. Taipa, canela-preta e concreto: estudo sobre o restauro de casas bandeiristas. São Paulo: Editora Romano Guerra, 2008.

MCC, MINISTĖRE DE LA CULTURE ET DE LA COMMUNICATION. Les secteurs sauvegardés. Rennes : CPS Imprimeur, 2000.

McELVAINE, R. S. The Great Depression: America 1929-1941. U.S.A: Times Books, 1993.

MENEGUELLO, C. O coração da cidade: observações sobre a preservação dos centros históricos. Revista eletrônica do IPHAN. Brasília, 2005.

METL. MINISTĖRE DE L'EQUIPEMENT, DES TRANSPORTS ET DU LOGEMENT. Les secteur Sauvegardés. França: Direction de l'architecture et du patrimoine, 2000 MONTANDON, D.T. Operações urbanas em São Paulo: da negociação financeira ao compartilhamento equitativo de custos e benefícios. 2009. Dissertação (Mestrado em Planejamento Urbano e Regional) - Faculdade de Arquitetura e Urbanismo. São Paulo: Universidade de São Paulo, 2009.

NEZ, H. De l'expertise associative à la constitution d'un contre-pouvoir. Action collective et concertation à Paris Rive Gauche. In : Espaces et sociétés, $n^{\circ} 151$. França: Eres, 2012.

NOBRE, E.A.C. Novos instrumentos urbanísticos em São Paulo: limites e possibilidades. São Paulo: Universidade de São Paulo, 2004. 
PARIS. Imprimerie Nationale. Loi sur les monuments historiques: promulguée le 31 décembre 1913. França: Bulletin archéologique, 1914.

PICKARD, R. Policy and Law in Heritage Conservation. Londres: Routledge, 2001.

PLANCHET, P. Des ZPPAUP aux AVAP du Grenelle II. In: Colloque « une nouvelle gouvernance pour la gestion du patrimoine architectural et paysager français ». Angers, 2011.

RODRIGUES, M. Imagens do passado: a instituição do patrimônio em São Paulo (1969 - 1987). São Paulo: Editora UNESP, 2000.

ROTHMAN, H. America's National Monuments: The Politics of Urban Preservation: University of Illinois Press, 1989.

RUBINO, S. As fachadas da história: as origens, a criação e os trabalhos do Serviço do Patrimônio Histórico e Artístico Nacional, 1936 - 1967. Dissertação (Mestrado) - Instituto de Filosofia e Ciências Humanas, Universidade Estadual de Campinas, 1992.

RUCKER, F. Les origines de la conservation des monuments historiques em France. Paris: Jouve, 1913.

SALA, D. Mário de Andrade e o Anteprojeto do Serviço do Patrimônio Artístico Nacional. Rev. IEB, São Paulo, n. 31, 1990.

SCET. Guide juridique des ZAC. ReseauScet. França: SCET pôle Réseau, 2013

SEMPLA, Secretaria de Planejamento. Plano Diretor 1985-200. São Paulo: Prefeitura de São Paulo, 1985.

SENAT, Service des affaires européennes. L'imposition des particuliers propriétaires d'immeubles anciens. France: Division des Études de législation comparée, 2002.

SENLY, D. Paris Rive Gauche. Images, réseaux et financement de l'aménagement. In: Les Annales de la recherche urbaine, n82. France, 1999.

SOMEKH, N. Patrimônio cultural em São Paulo: resgate do contemporâneo? Arquitextos, São Paulo, ano 16, n. 185.08, 2015. 
SPHAN. Proteção e revitalização do patrimônio cultural no Brasil: uma trajetória. Brasília: Sphan/ Pró-Memória, 1980.

STIPE, R, E. A richer heritage: historic preservation in the twenty-first century. U.S.A.: Historic Preservation Foundation of North Carolina, 2003.

SUTTON, S. A. Urban Revitalization in United States: policies and practices. Final Report. (United States Urban Revitalization Research Program). Seoul National University: 2008.

TARNE, A. E. To Destroy or to Preserve: Urban Renewal and the Legal Foundation of Historic District Zoning. Thesis. (Master of Urban and Regional Planning) - Virginia Commonwealth University. Virginia: 2010.

THE COUNCIL. Twenty years of the National Historic Preservation Act. United Statesof America: Advisory Council on Historic Preservation, 1986.

TOMASIN, D. Plan de sauvegarde des coproprietes en difficulte. Groupement de recherche sur les institutions, le droit de l'aménagement de l'urbanisme et de l'habitat (GRIDAUH). Paris, 2002.

VIANA, L.H.V. A influência do Banco Interamericano de desenvolvimento na formulação de políticas públicas: análise das condições de financiamento do Programa de Reabilitação da Área Central no Município de São Paulo Procentro. Dissertação. (Mestrado em Administração Pública e Governo). Fundação Getúlio Vargas. São Paulo, 2009

WEINBERG, N.G. Preservation In American Towns And Cities. E.U.A.:Routledge, 1979.

YÁZIGI, E. A preservação do Patrimônio Ambiental Urbano Paulista. CJ Arquitetura - Revista de Arquitetura Planejamento e Construção, no 16. São Paulo: FC Editora, 1977. 


\section{Documentos Técnicos}

ANVPAH \& VSSP Association Nationale villes et pays d'art et d'histoire, villes à secteur sauvegardés et protégés, Paroles d'élu, le secteur sauvegardé. Bayonne: ANVPAH \& VSSP, 2012.

CALIFORNIA STATE PARKS. Sustainable Preservation: California's Statewide Historic Preservation Plan, 2013-2017. California: National Park Service, 2013.

CEPAM, Centro de Estudos e Pesquisas de Administração Municipal da Fundação Prefeito Faria Lima. Solo Criado. São Paulo: CEPAM, 1975.

CEOUC. Comissão Executiva da Operação Urbana Centro. Ata da 19a Reunião Extraordinária. SPURBANISMO, 2016a

. Ata da 134ª Reunião Ordinária. SPURBANISMO, 2016b

. Ata da 135ª Reunião Ordinária. SPURBANISMO, 2016c

Ata da 136ª Reunião Ordinária. SPURBANISMO, 2016d

Ata da 137ª Reunião Ordinária. SPURBANISMO, 2016e

CTLU. Câmara Técnica de Legislação Urbanística. Relatório Técnico Transferência de Potencial Construtivo do Mosteiro São Bento. São Paulo, 2017.

DEUSO. Departamento de Uso do Solo. Planilha de controle dos processos de compra e cessão de potencial construtivo em São Paulo. São Paulo: Secretaria de Desenvolvimento Urbano, 2016.

DOM. Diário Oficial do Município. Declaração de saldo de potencial construtivo passível de transferência - SMUL/DEUSO 004A/17. São Paulo, 2017.

. Lei 12.350 - Procentro. São Paulo, 1993.

. Despacho 1998- 0.242.750-0, São Paulo, 1999.

Despacho SMUL.AOC.CTLU/007/2017. São Paulo, 2017.

. Despacho SMUL.AOC.CTLU/006/2017. São Paulo, 2017. 
. Processo 2017-0.155.948-6; Mosteiro de São Bento São Paulo (cedente)/ Gafisa (cessionário). São Paulo, 2017

. OPERAÇÃO URBANA CENTRO - 11ํ Relatório de acompanhamento. São Paulo, 2005

OPERAÇÃO URBANA CENTRO - 12ํㅡㄹ Relatório de acompanhamento. São

Paulo, 2006a

. OPERAÇÃO URBANA CENTRO - 13ำ Relatório de acompanhamento. São Paulo, 2006b

. OPERAÇÃO URBANA CENTRO - 14ํㅡㄹ Relatório de acompanhamento. São

Paulo, 2007a

. OPERAÇÃO URBANA CENTRO - 15ำ Relatório de acompanhamento. São Paulo, 2007b

. OPERAÇÃO URBANA CENTRO - 16ำ Relatório de acompanhamento. São

Paulo, 2008

. OPERAÇÃO URBANA CENTRO - 17ำ Relatório de acompanhamento. São Paulo, 2009a

. OPERAÇÃO URBANA CENTRO - 18ำ Relatório de acompanhamento. São

Paulo, 2009b

. OPERAÇÃO URBANA CENTRO - 19² Relatório de acompanhamento. São Paulo, 2010

. OPERAÇÃO URBANA CENTRO - 20ํ Relatório de acompanhamento. São

Paulo, 2011a

. OPERAÇÃO URBANA CENTRO - 21ํำ Relatório de acompanhamento. São Paulo, 2011b

. OPERAÇÃO URBANA CENTRO - 22ํㅡㄹ Relatório de acompanhamento. São

Paulo, 2011c

. OPERAÇÃO URBANA CENTRO - 23ํㅜㄹ Relatório de acompanhamento. São Paulo, 2012a 
. OPERAÇÃO URBANA CENTRO - 24ํㅜㄹotório de acompanhamento. São

Paulo, 2012b

OPERAÇÃO URBANA CENTRO - 25 Relatório de acompanhamento. São Paulo, 2013

. OPERAÇÃO URBANA CENTRO - 26ำ Relatório de acompanhamento. São Paulo, 2014a

. OPERAÇÃO URBANA CENTRO - 27ํㅡㄹ Relatório de acompanhamento. São Paulo, 2014b

DPH, Departamento do Patrimônio Histórico. Entrevista realizada com Mirthes Bahfi. São Paulo: Departamento do Patrimônio Histórico, 2015.

. Processo 1999- 0.221.838-5. São Paulo, 1999.

. Processo 2003 - 0.197.223-7. São Paulo, 2003.

EMURB, Empresa Municipal de Urbanização; COGEP, Coordenadoria Geral de Planejamento. Estudo de implantação do instrumento transferência aplicado às áreas históricas do município de São Paulo, definidas como Z8-200 na lei no 8.328 de 02/12/1975. São Paulo: COGEP, 1977.

. Compilação dos estudos realizados sobre o instrumento Solo Criado nas linhas econômico-financeira e físico-urbanística. São Paulo: COGEP, 1977.

Solo Criado: análise das experiências estrangeiras. São Paulo: COGEP, 1977.

. Projeto de Lei Operação Urbana Anhangabaú - versão 6. São Paulo: COGEP, 1989.

. Cartilha da Área Central - 1º versão. São Paulo, 1997.

EMURB - Empresa Municipal de Urbanização. Processo 1998-0.205.296-5. São Paulo, 1998a.

EMURB - Empresa Municipal de Urbanização. Processo 1998-0.242.750-0. São Paulo, 1998b. 
EMURB - Empresa Municipal de Urbanização. Processo 2016 -0.323.665-3. São Paulo, 2016c.

FRANÇA. Les zones de protection du patrimoine architectural, urbain et paysager (ZPPAUP). Paris: Imprimerie du Ministère de la Culture et de la Communication, 2002.

FRANÇA. Les sites classés et inscrits. Paris : Imprimerie du Ministère de la Culture et de la Communication, 2017.

MEMORANDO. CJ Arquitetura, Revista de Arquitetura, Planejamento e Construção. São Paulo, FC Editora, Ano IV no 16, 1977.

SÃO PAULO (cidade). Processo Municipal $\mathbf{5 0 . 0 4 3 ~ - ~ I n s t i t u i ~ o ~ D e p a r t a m e n t o ~ d o ~}$ Patrimônio Artístico - Cultural e dá outras diretrizes. (São Paulo, 1974).

SÃO PAUlO (cidade). Processo Municipal 29.735 - Desmembramento do Departamento do Patrimônio Artístico - Cultural. (São Paulo, 1975).

SEMPLA - Secretaria Municipal de Planejamento. Plano Diretor do Município de São Paulo: 1985-2.000. São Paulo, 1985.

SPURBANISMO. Norma de Apresentação de Propostas. São Paulo, 1997.

SPURBANISMO. Norma Apresentação de Propostas 59.00. São Paulo, 2016.

\section{Endereços eletrônicos}

ADVISORY COUNCIL ON HISTORIC PRESERVATION. Disponível em: www.achp.gov. Acesso em: 03 ago.2017.

ARCHITECTE DES BÂTIMENTS DE FRANCE (ABF). Disponível em: https://lannuaire.service-public.fr. Acesso em: 03 abr. 2017.

CODE D'URBANISME. Disponível em: www.legisfrance.fr. Acesso em: 28 mar.2017. COEFICIENTE DE APROVEITAMENTO. Disponível em: http://gestaourbana.prefeitura.sp.gov.br Acessado em: 22.dez.2017

CONJUR. Ministro garante continuidade de revitalização do Centro de SP. Disponível em: https://www.conjur.com.br Acesso em: 13 jan.2017 
HPF. HISTORIC PRESERVATION FUND. Disponível em: www.nps.gov Acesso em: 12 jun. 2017

IMAGEM. Parque Nacional Yellowstone e Parque Nacional Yosemite. Disponível em: https://www.goodfreephotos.com. Acesso em ago. 2017

L'ARCHITECTE DES BATIMENTS DE FRANCE. Disponível em https://lannuaire.service-public.fr. Acessado em 03.abr. 2017.

LOI DE FINANCES. Disponível em: https://www.senat.fr/role/fiche/loi_fin.html Acessado em: 21.ago.2017

NATIONAL HISTORIC LANDMARK. Disponível em: https://www.nps.gov/nhl/ Acessado em: 24.ago.2017

NATIONAL REGISTER OF HISTORIC PLACES. Disponível em www.nps.com. Acesso em 14 jan.2017

PARQUE YELLOWTONE. Criação do parque. Disponível em www.nps.gov . Acesso em 04 jul. 2017.

PARQUE YOSEMITE. Criação do parque. Disponível em www.nps.gov. Acesso em 04 jul. 2017.

SEMAPA. SOCIÈTÉ D'ECONOMIE MIXTE D'AMÉNAGEMENT DE PARIS. Disponível em: www.semapa.fr Acesso em 17 ago. 2017

TA. TAXE LOCALE D'ÉQUIPEMENT. Disponível em: http://www.cohesionterritoires.gouv.fr Aceso em: 19 ago. 2017

VIVAREAL. Preço de metro quadrado de terreno. https://www.vivareal.com.br Acesso em: 18 nov. 2017

\section{Legislação}

BAHIA (Estado). Lei estadual no 2.031 e 2.032, de 08 de agosto de 1927. Institui a Inspetoria Estadual de Monumentos Nacionais. Bahia, 1927.

BAHIA (Estado). Decreto no 5.339 de dezembro de 1927. Regulamenta a criação da Inspetoria Estadual de Monumentos Nacionais. Bahia, 1927.

BRASIL. Constituição da República dos Estados Unidos do Brasil, 24 de fevereiro de 1891. Rio de Janeiro, 1891. 
BRASIL. Decreto no 19.398 de 11 de novembro de 1930 - Institue o Governo Provisório da República dos Estados Unidos do Brasil, e dá outras providencias. Rio de Janeiro, 1930.

BRASIL. Decreto № 22.928 de 12 de julho de 1933 - Erige a cidade de Ouro Preto em monumento nacional. Rio de Janeiro, 1933.

BRASIL. Decreto no24.735 de 14 de julho de 1934. Aprova, sem aumento de despêsa, o novo regulamento do "Museu Histórico Nacional". Rio de Janeiro, 1934.

BRASIL. Decreto-Lei no25 de 30 de novembro de 1937. Organiza a proteção do patrimônio histórico e artístico nacional. Rio de Janeiro, 1937.

BRASIL. Decreto-Lei no 2.809 de 23 de novembro de 1940. Dispõe sobre a aceitação e aplicação de donativos particulares pelo Serviço do Patrimônio Histórico e Artístico Nacional. Rio de Janeiro, 1940.

BRASIL. Decreto-lei no 8.534, de 4 de janeiro de 1946. Passa a Diretoria do Patrimônio Histórico e Artístico Nacional o Serviço do mesmo nome, criado pela Lei número 378, de 13 de janeiro de 1937, e dá outras providências. Rio de Janeiro, 1946.

BRASIL. Lei no 378, de 13 de janeiro de 1937. Dá nova, organização ao Ministerio da Educação e Saude Publica. Rio de Janeiro, 1937.

BRASIL. Lei no 10.257, de 10 de julho de 2001. Regulamenta os artigos no 182 e 183 da Constituição Federal, estabelece diretrizes gerais da política urbana e dá outras providências. Brasília, 2001.

BRASIL. Lei no 13.303 de 30 de junho de 2016. Dispõe sobre o estatuto jurídico da empresa pública, da sociedade de economia mista e de suas subsidiárias, no âmbito da União, dos Estados, do Distrito. Brasília, 2016.

CONPRESP. Resolução 06/91 - Parque do Anhangabaú. São Paulo, 1991a.

CONPRESP. Resolução 11/91 - Aditamento à Resolução 6/91. São Paulo, 1991b.

CONPRESP. Resolução 37/92 - Tombamento da Área do Vale do Anhangabaú (vide RES. 06/91; RES. 11/92; RES. 16/04). São Paulo, 1992.

CONPRESP. Resolução 23/15 -Diretrizes para análise do estado de conservação do imóvel tombado para Leis de Incentivo. São Paulo, 2015. 
CONDEPHAAT, Conselho de Defesa do Patrimônio Histórico, Arqueológico, Artístico e Turístico. Resolução SC 43/80. Imóvel à Rua Florência de Abreu. São Paulo, 1980.

E.U.A. ESTAdOS UNIDOS DA AMÉRICA. Public Law 16 U.S.C. 431 - 433 American Antiquities Act. Washington D.C., 1906.

E.U.A. ESTADOS UNIDOS DA AMÉRICA. Public Law 16 U.S.C. 461 - 467 - Historic Sites Act. Washington D.C., 1935.

E.U.A. ESTAdOS UNIDOS DA AMÉRICA. Public Law No. 81 - 408, 63 Stat. 927. Washington D.C., 1949

E.U.A. ESTADOS UNIDOS DA AMÉRICA. Housing Act 1949 - Public Law 171-63 Stat. 413. Washington D.C., 1949.

E.U.A. ESTADOS UNIDOS DA AMÉRICA. Public Law 89 - 665 - National Historic Preservation Act. Washington D.C.,1966.

FRANÇA. Circulaire $\mathrm{n}^{\circ} \mathbf{7 8 - 1 5}$ du 17 janvier 1978. relative aux plans de sauvegarde et de mise en valeur des secteurs sauvegardés. Paris, 1978.

FRANÇA. Décret no84-304 du 25 avril 1984. Relative aux zones de protection du patrimoine architectural, urbain et paysager. França, 1984.

FRANÇA. Loi completant la loi du 31 décembre de 1913 sur les monuments historiques. Paris, 1913.

FRANÇA. Loi no 62-903 du 4 août 1962. Complétant la législation sur la protection du patrimoine historique et esthétique de la France et tendant à faciliter la restauration immobilière. Paris, 1962.

FRANÇA. Loi n 67-1253 du 30 décembre 1967. D'orientation foncière. Paris, 1967. FRANÇA. Loi n75-1328 du 31 décembre 1975. Dite Galley portant reforme de la politique foncière. Paris, 1975.

FRANÇA. Loi no83-8 du 7 janvier 1983. Relative à la reparation de compétences entre les communes, les départements, les regions et l'Etat - "Loi Defferre". Paris, 1983. 
FRANÇA. Loi no93-24 du 8 janvier 1993. Sur la protection et la mise en valeur des paysages et modifiant certaines dispositions législatives en matiére d'enquêtes publiques. Paris, 1993.

FRANÇA. Loi n 96-590 du 2 juillet 1996. Relative à la Fondation du Patrimoine. Paris, 1996.

FRANÇA. Loi no 2000-1208 du 13 décembre 2000. Relative à la solidarité et au renouvellement urbains (SRU). Paris, 2000

FRANÇA. Loi $\mathbf{n}^{\circ}$ 2016-925 du 7 juillet 2016. Relative à la liberté de la création, à l'architecture et au patrimoine. Paris, 2016.

FRANÇA. Code de I'Urbanisme, version consolidée au 1 janvier 2017. Paris, 2017.

PERNAMBUCO (Estado). Lei estadual no 1.918, em 24 de agosto de 1928, autoriza o Governo a criar uma Inspetoria Estadual de Monumentos Nacionais e um Museu Histórico e de Arte Antiga, a ela subordinado. Pernambuco, 1928.

SÃO PAULO (cidade). Acto no $\mathbf{8 6 1}$ de 30 de maio de 1935. Institui o Departamento de Cultura e Recreação. São Paulo: 1935.

SÃO PAULO (cidade). Decreto no 33.390 de 14 de julho de 1993. Cria a Comissão ProCentro para atuar no Programa de Requalificação Urbana e Funcional do Centro de São Paulo e dá outras providências. São Paulo, 1993.

SÃO PAULO (cidade). Decreto no 51.415, de 16 de abril de 2010. Dispõe sobre a cisão da Empresa Municipal de Urbanização - EMURB, conforme autorizado pela Lei no 15.056 , de 8 de dezembro de 2009, bem como aprova os contratos sociais das empresas públicas São Paulo Urbanismo - SP- Urbanismo e São Paulo Obras - SPObras. São Paulo, 2010.

SÃO PAULO (cidade). Decreto no 40.753 de 19 de junho de 2001. Cria a Coordenadoria de Programas de Reabilitação da Área Central - Procentro. São Paulo, 2001.

SÃO PAULO (cidade). Lei no 7.688 de 30 de dezembro de 1971. Plano Diretor de Desenvolvimento Integrado/PDDI. São Paulo, 1971. 
SÃO PAULO (cidade). Lei no 7.805, de 01 novembro de 1972. Dispôs sobre o parcelamento, uso e ocupação do solo do Município de São Paulo. São Paulo, 1972

SÃO PAULO (cidade). Lei no 8.328, de 02 de dezembro de 1975. Dispõe sobre o parcelamento, uso e ocupação do solo no município, nas zonas de uso especiais Z8, cria novas zonas de uso, amplia zonas existentes e dá outras providências. São Paulo, 1975.

SÃO PAULO (cidade). Lei no 9.725, de julho de 1984. Dispõe sobre a transferência de potencial construtivo de imóveis preservados; estabelece incentivos, obrigações e sanções relativas a preservação de imóveis, e da outras providencias. São Paulo, 1984.

SÃO PAULO (cidade). Lei no 10.032, de 27 de dezembro de 1985. Dispõe sobre a criação de um Conselho Municipal de Preservação do Patrimônio Histórico, Cultural e Ambiental de São Paulo. São Paulo, 1985.

SÃO PAULO (cidade). Lei no 10.209, de 9 de dezembro de 1986. Dispõe sobre a construção de habitações de interesse social para moradores de habitação subnormal, concede incentivos, e dá outras providências. São Paulo, 1986.

SÃO PAULO (cidade). Lei no 11.090, de 16 de setembro de 1991. Estabelece programa de melhorias para a área de influência imediata do Vale do Anhangabaú, cria incentivos e dá outras providências. São Paulo, 1991.

SÃO PAULO (cidade). Lei no 7.805 de 01 novembro de 1972. Dispõe sobre o parcelamento, uso e ocupação do solo do Município de São Paulo. SÃO PAULO, 1972.

SÃO PAULO (cidade). Projeto de lei 0087/84. São Paulo, 1984

SÃO PAULO (cidade). Lei $\mathbf{n}^{\circ}$ 10.676, de 7 de novembro de 1988. Aprova o PlanoDiretor, institui o Sistema de Planejamento do Município de São Paulo, e dá outras providências. São Paulo, 1988.

SÃO PAULO (cidade). Projeto de Lei no 604 de 19 de agosto de 1993. Programa de Requalificaçao Urbana e Funcional do Centro de São Paulo - PROCENTRO. São Paulo, 1993. 
SÃO PAULO (cidade). Lei no 12.349 de 6 de junho de 1997. Estabelece programa de melhorias para a área central da cidade, cria incentivos e formas para sua implantação, e dá outras providências. São Paulo, 1997a.

SÃO PAULO (cidade). Lei no $\mathbf{1 2 . 3 5 0}$ de 6 de junho de 1997. Concede incentivo fiscal aos proprietários de imóveis ou aos patrocinadores das obras de recuperação externa e conservação de imóveis localizados na Área Especial de Intervenção, objeto do Programa de Requalificação Urbana e Funcional do Centro de São Paulo PROCENTRO, ou outro equivalente que venha a ser implantado, e dá outras providências. São Paulo, 1997b

SÃO PAULO (cidade). Lei no 13.430 , de 13 de setembro de 2002. Plano Diretor Estratégico. São Paulo, 2002

SÃO PAULO (cidade). Lei no 13.885, de 25 de agosto de 2004. Estabelece normas complementares ao Plano Diretor Estratégico, institui os Planos Regionais Estratégicos das Subprefeituras, dispõe sobre o parcelamento, disciplina e ordena o Uso e Ocupação do Solo do Município de São Paulo. São Paulo, 2004

SÃO PAULO (cidade). Lei no 15.056, de 8 de dezembro de 2009. Autoriza a cisão da Empresa Municipal de Urbanização - EMURB. São Paulo, 2009.

SÃO PAULO (cidade). Lei no $\mathbf{1 5 . 0 5 6}$ de 8 de dezembro de 2009. Autoriza a cisão da Empresa Municipal de Urbanização - EMURB. São Paulo, 2010.

SÃO PAULO (cidade). Lei no 16.050, de 31 de julho de 2014. Aprova a Política de Desenvolvimento Urbano e o Plano Diretor Estratégico do Município de São Paulo e revoga a Lei no 13.430/2002. São Paulo, 2014.

SÃO PAULO (cidade). Lei no 16.402, de 22 de março de 2016. Disciplina o parcelamento, o uso e a ocupação do solo no Município de São Paulo, de acordo com a Lei no 16.050, de 31 de julho de. 2014. São Paulo, 2014.

SÃO PAULO (cidade). Portaria no113 de 08 de maio de 2001. São Paulo, 2001 
SÃO PAULO (cidade). Projeto de lei no 44/45 de 09 de abril de 1975. Dispõe sobre a criação do Departamento de Informação e Documentação Artística e dá outras providências. São Paulo, 1984

SÃO PAULO (Estado). Lei no 10.247 de 22 de outubro de 1968. Estabelece diferentes níveis de tombamento e raio de entorno de $300 \mathrm{~m}$ (variável de acordo com o entorno imediato), e institui o CONDEPHAAT, Conselho de Defesa do Patrimônio Histórico, Artístico, Arqueológico e Turístico. São Paulo, 1968. 